Historic, Archive Document

Do not assume content reflects current scientific knowledge, policies, or practices. 



\section{CONTENTS OF CATALOGUE.}

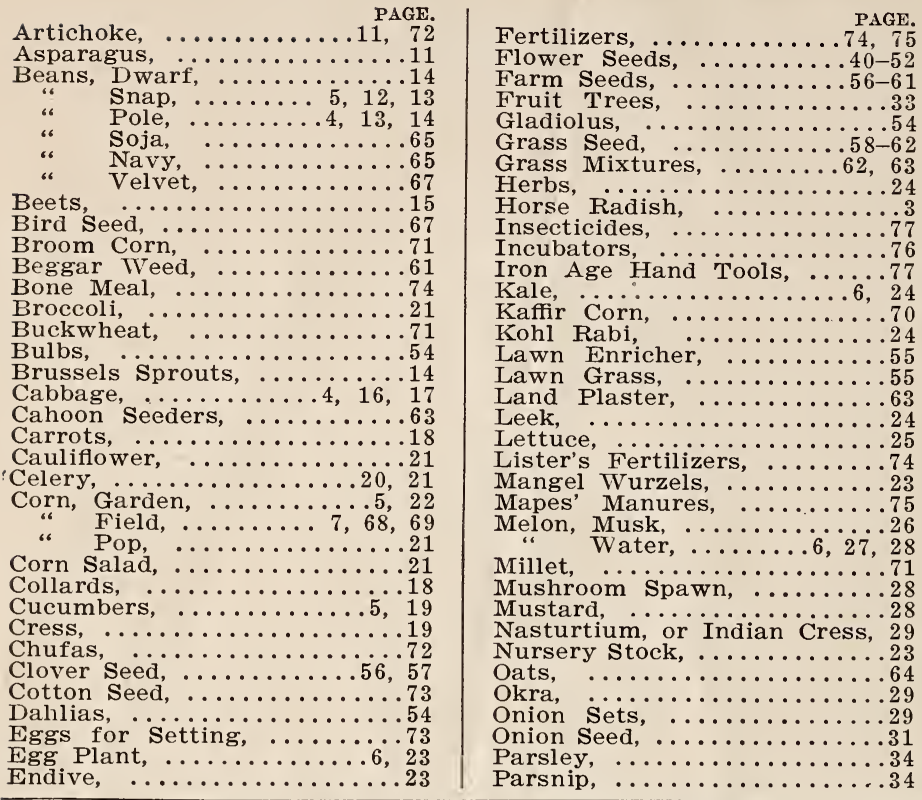

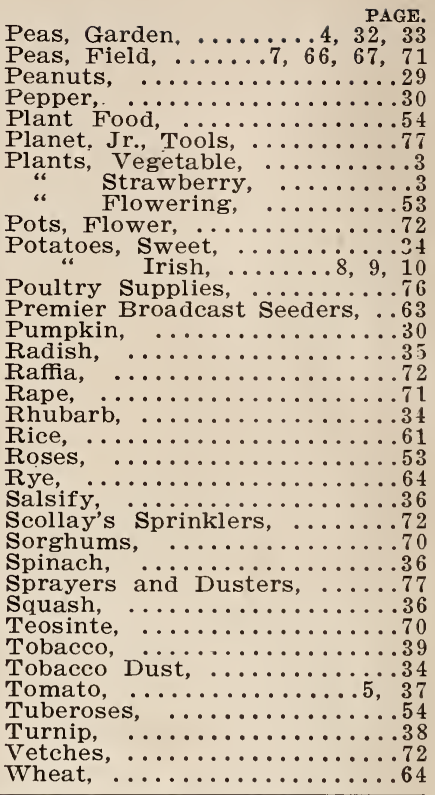

\section{BOWKER'S INSECTICIDES AND FUNGICIDES.}

These insecticides are put up from formulae that have been thoroughly tested and approved by the most successful fruit and vegetable growers in this country. The intelligent use of insecticides and fungicides will save our farmers, gardeners and truckers thousands of dollars. The Bowker Chemical Company has an established reputation; and their preparations can be used with the fullest confidence for the different insects, fungi or diseases for which they are recommended. We will take pleasure in sending Bowker's "Hand-Book of Injurious Insects and Plant Diseases" upon request. Full directions accompany each package.

BOWXER'S BOX-AII. A splendid remedy for potato bugs, beetles, rust and rot. 5 lbs. and over, 50c.; 10 -1b. can, $\$ 1.00$

BOWKER'S PYROX. An insecticide and fungicide for fruit trees. Prevents rot, mildew. apple scab, brown rot on peaches, plum rot, and kills leaf eating insects. 5-lb. package, 75c.; 10-1b. package, \$1.25.

BOWKER'S BODO. A splendid preparation of Bordeaux mixture. Of great strength, and carefully prepared by a competent chemist. 5-1b. can, 50c.; 10-1b. can,, $\$ 1.00$.

BOWKER'S BODIIME. A most useful preparation for banding trees, to protect them from canker worms and other insects. 5-1b. can, $75 \mathrm{c}$; $10-1 \mathrm{~b}$, can, $\$ 1.25$.

BOWKER'S DISPARERE. A splendid insecticide for fruit and shade trees. Is an effective remedy for the elm beetle, web worm, tussock moth, and all insects which prey on foliage or fruit. One application is usually sufficient, as it sticks all through the summer, and at the same time does not affect the appearance of the foliage in any way. 2 lbs. and over, 50c.; 5-lb. can, $\$ 1.00$

Owing to lack of space, we can only give short descriptions, but we urgently request all who are interested in insecticides and fungicides to write us for Hand-Book of Bowker's insecticides. It gives valuable information in regard to insects and diseases affecting fruits and garden crops and shade trees. Mailed free upon request.

T. W. WOOD, President.

L. R. SPENCER, Secretary and Treasurer.

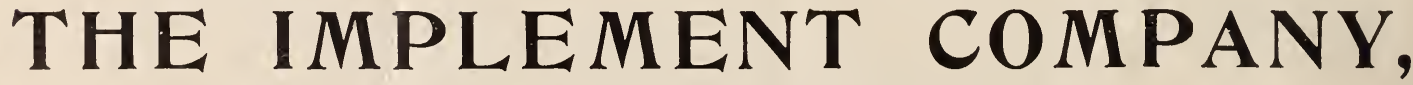
1302-1304 East Main Street, Richmond, Virginia.

Write for prices and catalogues if you want to buy : ENGINES, SAW-MILLS, THRESHERS, HORSE-POWERS, CORN-COB and FEED-MILLS, or CUTTERS, ROOFING, FENCING, WIRE NETTING, BUGGIES, WAGONS, HARNESS, PUMPS, WELL FIXTURES, or any AGRICULTURAL IMPLEMENTS.

FINE CARRIAGES AND HARNESS A SPECIALTY.

The Implement Company carry one of the largest and best stocks of Agricultural Implements in the Southern States, making a specialty of Farm Wagons, Fine Carriages, Buggies, Harness, etc. It will pay you to get prices and catalogue before purchasing. 
WOOD'S SEEDS are increasing in popularity everywhere. While they are specially grown and selected with a view to their adaptability to the conditions and requirements of the South, their high quality and superiority is being very generally recognized, and our trade in the North and West is increasing largely every year. A great many seeds grown in this section succeed and do much better in all sections of the country than seeds grown in the North and West. Such seeds as Water Melon, Second Crop Seed Potatoes, Lima Beans, Collards, Seed Corn, Cantaloupes, Mustard, Okra, Salsify, Squash, Tobacco, and many others, unquestionably produce superior crops in this climate, and seeds grown here from these crops will give the very best crop results in all sections. Our other improved and selected strains of seeds, controlled by us exclusively, are grown in those sections where they attain the highest development.

Our trade in our leading specialties practically covers the entire country, and any Southern seeds we can always supply to the very best advantage, both as regards quality and price.

We have very extensive trial grounds on our Hollybrook Farm, and are constantly experimenting and testing all the leading varieties of seeds grown, with a view of offering only the best and most satisfactory kinds to our customers.

OUR STORE AND WAREHOUSE FACILITIES. We occupy, altogether, five large warehouses, which are used for the proper storage and handling of our seeds. We have also two branch retail stores, corner of Sixth and Marshall Streets, and 1707 East Franklin Street (at each of the markets in our city), and our facilities in every respect for the proper conduct of our business are not surpassed by those of any seed firm in this country. This enables us to give the most careful and prompt attention to all orders entrusted to us.

IN GRASS, CLOVER AND FARM SEEDS our business is one of the largest in the United States, and we have established a very high reputation for the quality of seeds sent out by us, supplying the largest and most critical farmers year after year with their wants in this line. The information contained in our catalogue in regard to Field Seedș, especially grasses and clovers, is particularly valuable, and our farmers will find much useful information contained therein.

Thanking our customers for their liberal orders in the past, and pledging our best and most careful attention for future business, we remain,

January 1, 1903.

Very truly yours,

T. W. WOOD \& SONS.

\section{GENERAL INFORMATION AND TERIMS OF SALE.}

HOW TO SEND MONEY. Money can safely be sent by bank check, post-office order, express money order, registered letter, or express. Postage stamp remittances in small amounts are also satisfactory.

QUICK FREIGHT SHIPMFNTS. Richmond is the best distributing point in the South, railroads radiating in every direction, giving prompt and efficient service and low freight rates, so that customers can depend on having their orders filled promptly and delivered without delay.

SEIDS BY IXPRESS. By special agreement, the express companies will carry seeds and plants from Richmond to all points in the South at a rate of twenty per cent. less than usual merchandise rates.

IN VIRGINIA the rate on five pounds or less to any point in the State is 25 cents; on fifty pounds or less, 50 cents; more than fifty pounds, one-and-one-half times the freight rate (not released) on the same elass of goods.

SFEDS BY IMAII POSTAGE PAID. We pay the postage on packets, ounces and quarter-pounds. When ordering in large quantities to be sent by mail, ada for postage 10 cents per pound or pint, 15 cents per quart, except on Onion sets, postage on which is 10 cents per quart.

WCOD'S PACKET SErDS. All packets of seeds which are catalogued at 5 cents per packet we will supply at the following rates, in quantity: Six 5-cent packets for 25 cents; thirteen 5 -cent packets for 50 cents; thirty 5 -cent packets for $\$ 1.00$-all sent postage paid by us. In ordering packets which retail at 10 cents per packet. they can be counted as two 5-cent packets; those which retail at 15 cents per packet, as three 5-cent packets, and so on. This special offer applies to packet seeds only, and not to seeds by the ounce, quart, pound, etc.

PRICES OT GRASS AND CIOVIR SFEDS, SEFD GRAIN, SFED POTATOFS, and other field seeds are constantly fluctuating. The prices given in this catalogue are those ruling at the time this is issued in January. We will take pleasure at any time in quoting prices on request, or will always fill any orders entrusted to us at as low prices as possible for first-class seeds.

ABOUT WARRANTING SEFDS. While we exercise great care to have all seeds pure and reliable, we give no warranty, express or implied, as to description, quality, productiveness, or any other matter connected with the seeds, bulbs, or plants we send out, and will not be in any way responsible for the crop. If the purchaser does not accept the goods on these terms, they are to be returned at once, and any money that has been paid for them will be refunded. Every order received for articles in this catalogue will be executed on these conditions only. 


\section{CALENDAR OF MONTHLY OPERATIONS. \\ What to Plant and When to Plant for Each Month in the Year.}

Applies to sections same climate as Middle Virginia. For other sections allowance must be made, as they are earlier or later. For instance, Charleston, S. C., district, plans should be considered for two weeks earlier in the Spring and two weeks later in the Fall.

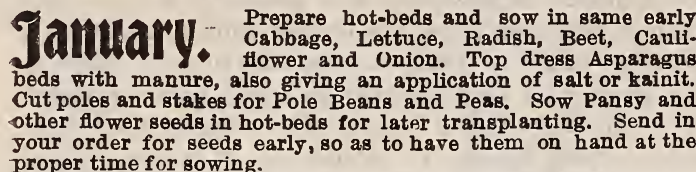

For the Farm,-Top dress Grass and Clover fields or Fall sown grain, and if weather is open use every opportunity to prepare land for Spring crops.
para

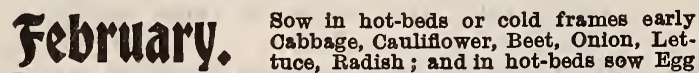
Plant, Tomato and Pepper. The last of the month sow in open ground early Peas, Spring Kale, Beets, Spinach, Oarrot, Celery, Radish and Parsley. Set out Asparagus Roots, Onion Sets, Horse Radish Roots and hardy Letuce plants. Farly plantings of Potatoes can be made. Hardy flower seeds can be forwarded either by sowing in hot-beds or in pots and boxes in the house for later transplanting. Sow Wood's Evergr

Grass, the earlier in the spring this is sown the better. For the Farm. - Prepare plant beds and put in Tobacco
ased. Sow Canada. Field Peas and Oats, and towards the sed. Sow Canada Field Peas and Oats, and towards the
end of the month, Grass and Olover Seeds can safely be put in. Sow Dwarf Essex Rape for sheep grazing.

11 This is the active month for sowing all kinds 12 al (1). $\begin{aligned} & \text { of hardy seeds, and the sooner most of them } \\ & \text { are sown the better, if the weather is favor- }\end{aligned}$ able. We name them in the order in which they should be sown, viz.: Garden Peas in varieties for succession, Cauliflower, Early Cabbage seed, Onion, Celery, Spinach, Leek, Parsley, Lettuce, Radish, Beet, Asparagus, Carrot, Parsnip, Salsify, etc. Under glass, Bow Tomato, Pepper, and Egg-Plant seed. Plant Irish Potatoes, Asparagus and Rhubarb roots, Onion Sets, etc. Set Potatoes, Asparagus and Rhubarb roots, Onion Sets, etc. Set
out Cauliflower, Cabbage, Onions, and Lettuce plants, from hotbeds, after they have been hardened by leaving the glass open at night. Sow Herbs in a warm border. Plant out Aspanagus Roots. Prepare Melon, Cucumber and Squash hills for later planting. Sow the hardy kinds of flower seeds, as they will flower earlier. Sow Lawn Grass Seed.

For the Farm.-Sow Winter and Spring Oats, Canada Field Peas with Oats, Clover seed, Grass seeds of all sorts, Tobacco seed. Plant Artichokes for hogs. Sow Dwarf Esser Rape. T1) 1 Tlant Early Potatoes. Sow Cabbage, Lettuce and Л1. Temsts, in open ground for succession. Sow al Wu, Spring Kale, Celery, Cat, and Asparagus Roots ; bed Sweet Potatoes ; plant early Corn, Garden Peas, Snap Beans, and late in the month Cucumber,
Squash, Watermelon and Cantaloupe can be planted. Vine Seeds are tender, so should the weather be cold or wet, defer planting till May. Lawn Grass Seed can also be sown ony time this month. but the earlier the better. Sow hardy Flower Sesds, and after the m:ddle of the month the half hardy kinds can alse be sown, and Dahlias, Gladiolus and Oanna Bulbs set out.

For the Farm. -Sow Spring Oats, Clover and Grass Seeds, but get them in as early as you can. Later in the month sow Mangel Wurzels for stock; plant Oorn, Cotton, Chufas, Peanuts, etc. 11 Most of the tender seeds can be sown this month. 1121 . We name the seeds in the order of their hardiness : Salsify, Parsley, Beet, Pole and Snap Beans, Sugar Corn, and Tomato of all kinds. Plant Black-eye Peas, Lims Beans, squash, Cucumber, Watermelon, Cantaloupe, Okrs and Pumpkin seed, Late Cabbage seed can be sown this month to make plants for setting out for fall use. Set out plants of Tomato, plants for setting out for fall use. Set out plants of Tomato,
Pepper, Strawberry. Sweet Potato and Egg-Plant. Sow flower seeds and plant flowering bulbs.

For the Farm.-Plant Sugar Beets and Mangel Wurzel for winter feeding of stock. All the Sorghums, Millets and Fodder plants can be sown; likewise Cow Peas, Soja, Navy and Tree wise Corn, Peanuts and Cotton. Set out Tobacco plants. Fil Set out Cabbage, Tomato, Egg-Plant, Pepper and likewise Late Cabbage and Cauliflower for winter use. Plant Okra, Watermelon, Oantaloupe, Cucumber, Squash and Pumpkin for late use, and Snap and Pole Beans and Sweet Corn for succession. Plant Late Potatoes for winter use; summer sowing of Beets for late crop can also be made.

For the Farm. - Sow the Millets, Cow Peas, Sorghum, Soja Beans. Navy Beans, and plant Late Oorn. Mangel Wurzel Beets can yet be sown for stock, but the seed should be soaked twertyfour hours before sowing.
F11 Plant Snap Beans for succession and Sugar Oorn 11. for late roasting ears. Set out Late Cabbage plants best month to sow Ruta Bagas, but they can also be sown in August. Sow early Turnips. Plant Oucumbers for pickling and table, and Late Potatoes for winter use.

For the Farm. - Sow German or Bungarian Millet for hay or fodder; likewise Corn in drills for ensilage or fodder. Buckwheat can be sown for bees, as an improver of the soll. and for grain. Plant Nary Beans, Black, Black-eye and Whippoorwill Peas. Sow Orimson Clover at the last working of Corn or Cotton. Sow Dwarf Essex Rape for sheep and cattle grazing.

\section{Hugust.}

Plant Sugar Corn for late roasting ears. Continue planting Snap Beans for the table and pickles. If any Cabbage plants remain unplanted, put out at once; likewise Celery plants. Trim of the tops of Oelery before planting, if the plants are large. Sow Wood's Cabbage Lettuce seed for fall hesding, likewise Endive. Wood's Lightning Excelsior Peas sown this month yield a good fall crop. Sow Spinach and Ksle. Finish sowing Ruts Baga
seed. All kinds of Turnip seods can be sown during the month.

For the Farm.-Crimson Olover is one of the best crops grown. and should be sown on every vacant place where crops have been cleared off; if it is not required for feed, it will im. prove the soil equal to manure when turned nnder. Rye and Barley should be sown for $f$ all and winter grazing, and afterwards will make a crop of grain. Sow Vetch and Rape, and towards the end of the month Grass and Clover seeds cañ safely be put in.

\section{September.}

Our Fall Catalogue, Issued during A ugust, gives full information sowing; mailed free npon request. Sow Lettuce, early Cabbage, Caulifi Caulifiower and Onion for transplanting in November. Sow the
Cabbage late in the month, otherwise they may go to seed. Put Cabbage late in the month, otherwise they may go to seed. Put
out Onion Sots. Sow Winter Ra lishes, Spinach, Turnips, Mus. tard, Corn Salad and Kale. Dutch Bulbs, Hyacinths, Tulips, tc.. can be planted towards the ejd of the month Sow Wood's Evergreen Lawn Grass. Nothing adds more to the attractiveness and beauty of a home than a nicely kept green lawn. Set out Strawberry plants.

For the Farm.- Sow Crimson Clover as early in the month as convenient, though any time during the month will do; it makes fine winter grazing and hay. Land will be greatly improved by growing this crop. Winter Oats will do well sown this month, as they will get well rooted before winter. Sow all kinds of Grass and Clover seeds and Winter and Sand Vetch. Continue to sow Barley and Rye, as they are useful for winter grazing as well as for grain.

\section{October.}

Put out Onion Sets. Sow Cabbage (early sorts), Turnips for Salad, Kale, Mustard, Spinach and Lettuce. Towards the end of the month set out Cabbage and Lettuce plants to stand out during the winter. Sow Lawn Grass Seed. Put down Asparagus beds. Fall seeding does better than spring seeding. Plant Hyacinths. Tulios, etc. Sow Pansy seed in cold frames for spring plants. Plant Strawberrits.

For the Farm. - All kinds of Grass and Clover seeds can be sown this month, but the earlier Clover seed is put in the better, Sow Wheat, Oats, Rye, Barley, Vetches. If you have not received a copy of our Fall Oatalogus giving full information in regard to these crops send for same at once.

\section{november.}

Sow Lettuce and early varieties of Oabbage in cold frames. Set ont Oabbage, Lettuce and Strawberry plants. Plant out Asparagus Roots. Lawn Grass Seed can yet be sown, but the earlier it is put in the better. All kinds of Flowering Bulbs set out in the fall can be put in this month. Potatoes can also be planted now to come in the spring but require to be planted deeper than spring planted seed. Plant hardy Roses, and set out Fruit Trees and small fruits.

For the Farm.-Whest, Rye, Barley, Vetches, Timothy and Herds Grass seed oan yet be sown, but the earlier they are put in the better. Bow Canada Field Peas.

December.

Oabbage and Lettuce can be sown towards the end of the month in hot-beds or cold frames, and Beets, Radish and or winter The winter growing of Lettuce in hot beds usually proves very profitable and satisfactory. Early potatoes can be planted in open weather up to Christmas. Canada Field Peas can also be sown, but when seeded 


\section{STRAWBERRY PLANTS.}

Strong, vigorous and well-grown plants, of the best varieties for this section. All of the varieties we offer have been tested and fruited by us, and are only such as are recommended by experienced strawberry growers as the best for the South. Special leaflet giving information regarding culture of strawberries mailed on request.

Varieties marked $\mathbf{P}$ are pistillate, or imperfect blooming sorts, and require to be planted with some of the perfect blooming sorts.

EXCrISIOR. This has proven itself to be, beyond all question, the best extra early berry in cultivation. Wherever it has been tried it has given splendid satisfaction, and it is now being planted by the largest and most successful growers for early market throughout the South. It is really the earliest berry of real value ever introduced, ripening its crop very early, before the markets are glutted and while prices are high. The whole crop is picked and sold before most of the varieties classed as early begin to ripen, and therefore it does not conflict with the picking of the main crop. It is a self pollenizer; the fruit is of excellent quality, very firm, color perfect, making an excellent shipping berry, which is very attractive and salable. So far as tested, it has done. well everywhere.

IADY THOMPSON. Another good early variety which originated in North Carolina. Makes a largesized berry; perfect bloomer; good grower and shipper; fine shape, good color and splendid flavor. The season of this lasts longer than the Excelsior, and the berries hold up well, even towards the last.

BRANDYWINE. This is pronounced by one of the largest strawberry growers in the South to be the great medium all-purpose berry. It succeeds on all soils, and withstands adverse conditions of weather better than any other kind. The plant is of vigorous growth, profuse bloomer, producing berries of large size and of a brilliant and handsome color. It is a good shipper and fine flavored berry, equally well adapted for shipping, the home market, and the private garden.

CIYDE. A favorite main-crop strawberry with Southern growers and truckers, both for shipping and the home market. It bears an enormous crop of splendid fruit that runs large, even to the very last. A good shipper, carrying to distant points, and arriving in perfect condition. It is medium early in maturity, of good color, and an attractive, salable variety.

WIIIIAM BEIT. A splendid new variety of great promise; produces fruit of the highest quality. Berries large, uniform in shape, glossy red; ripens all over at once. On our Hollybrook farm this has proved to be one of the best, both for home use and market. Mid-season.

BRUNETTE. An excellent variety for the home garden. High color and firm flesh. Fine flarored. and makes an attractive table sort. It is also especially valuable for preserving or canning.

NICK OHMrrs. A most desirable mid-season variety. Fruit of large size. Beautiful form and color and of excellent quality. Well adapted either for market or home use.

HOWEI.'S SEEDING. This belongs to the giant tribe of strawberries, and is also an exceedingly heavy bearer. The berries, besides being of largest size, are exceedingly well colored, attractive and fine flavored. Splendid variety for both home use and market.

SEAFORD. (P.) A very large, enormously productive berry, very valuable for home use or near by market. Not so well adapted for shipping, but those who desire splendid quality, combined with great productiveness, should plant this variety. It must be planted with other sorts for best results.

AROMA. This is another variety that has done particularly well on our Hollybrook farm, proving to be even a better mid-season and late berry than the Gandy. It grows to a large size, is of splendid flavor and very productive. Admirably adapted either for home use or market.

GANDY. A splendid late berry; well adapted for either market, home use or shipping. The fruit is large and firm, regular in size and shape, handsome and showy. This is one of the most popular varieties in our list, and succeeds well wherever grown.

BUBACE. (P.) In vigor of plant, productiveness, large size and profitableness this has no superior. It is planted almost as generally as the Concord grape, as it succeeds in every State in the Union. A splendid main crop variety.

Price of all varieties: 25c. per dozen; 60c. per 100; $\$ 3.50$ per 1,000 . The 1,000-rate only applies to orders for one thousand plants or more, but customers can select four different kinds in a 1,000 order; or we will send 500 plants, composed of three different kinds, customers' selection, for $\$ 2.00$. Orders for less quantity than 500 plants are charged at the 100 -rate.

Special prices quoted to growers who require large quantities.

\section{VEGETABLE PLANTS.}

In their proper seasons, we will have large quantities of all the plants listed below, well grown and stocky, and all grown from the very best seeds. Purchasers may rely upon having their orders filled the day after received, the weather permitting. They will be packed in moss, and will carry long distances. Plants by mail are at purchaser's risk. No charge for packing, etc. To avoid lying over in express office on Sunday, no plants will be shipped on Saturday unless specially ordered.

If to be mailed, add 5 cents per dozen, 15 cents per 100 for postage.

EARIX CABBAGE PIANTS. Ready January, February, March, April. Per 100, 30c.; 1,000, \$2.50. IATI CABBAGI PIANTS. Ready June, July, August and September. Per 100, 25c.; $1,000, \$ 2.00$

TOMATO PIANTS. Ready April, May, June and July. Hot-bed plants per dozen, 10c.; 100, 35c.; 1,000 $\$ 3.00$. Transplanted plants, large and stocky, per dozen, $15 \mathrm{c}$.; $100,75 \mathrm{c}$; $1,000, \$ 6.00$

CAUIrfIOWrR PLANTS. Ready January, February and March, and for late planting during July and August. Price per $100,50 \mathrm{c}$; $1,000, \$ 4.00$

CELRRY PIANTS. Ready June, July and August. Per $100,35 \mathrm{c}$; ; 1,000, $\$ 3.00$

IFTTUCE PIANTS. Ready February, March, April, October and November. Per 100, $25 \mathrm{c}$; $1,000, \$ 2.00$.

EGG PIANTS. Ready May and June. Per doz. 20c.; 100, $\$ 1.00$.

SWIET POTATO PIANTS. Ready May and June. Per 100, 25u.; 1,000, $\$ 2.00$

PFPPER PIANTS. Ready May and June. Per doz. 20c.; 100, $\$ 1.00$

HOP PIANTS, 25c. each; $\$ 2.00$ per dozen.

SAGE ROOTS, $10 \mathrm{c}$. each; $75 \mathrm{c}$. per dozen.

THYMP ROOTS, $10 \mathrm{c}$. each; $75 \mathrm{c}$. per dozen.

FORSE RADISH ROOTS, doz. $20 \mathrm{c}$; $100,60 \mathrm{c}$

BHUBARB ROOTS; strong roots, 10c. each; $\$ 1.00$ per dozen.

Buyers of large quantities will please write for special prices. 


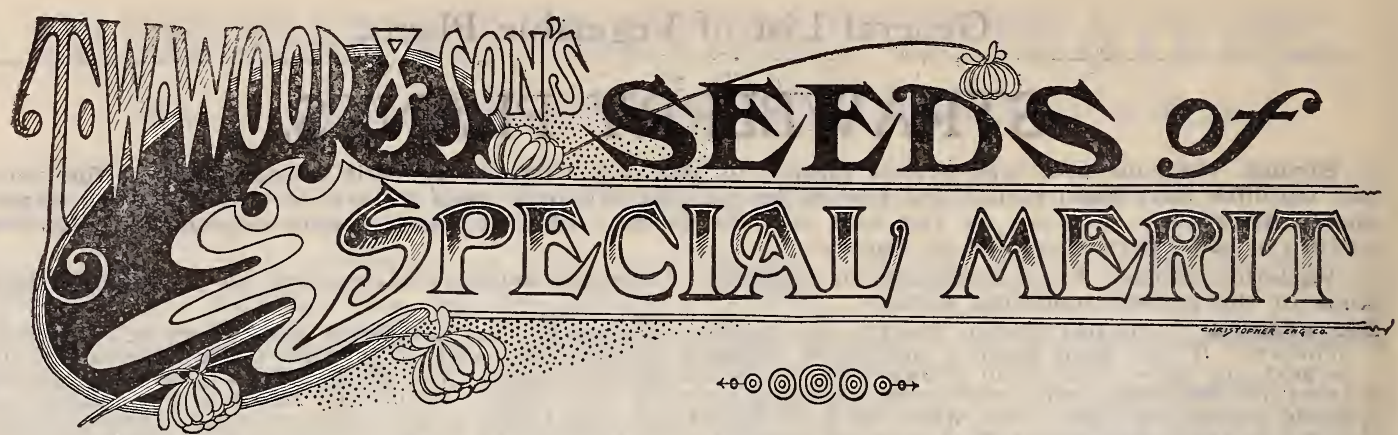

\section{WOOD'S PEDIGREE EXTRA EARLY PEA.}

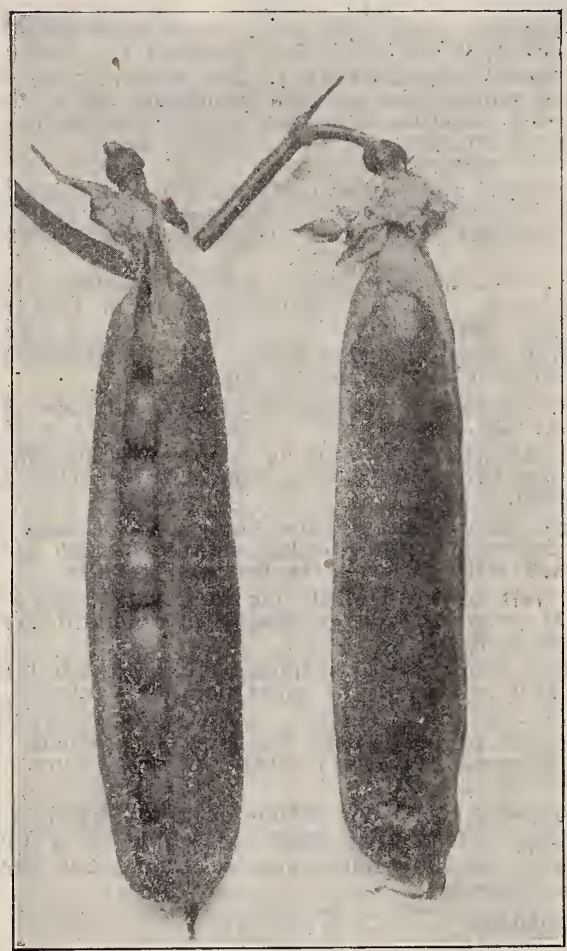

Wood's Pedigree Extra Early Pea.

This is all that its name implies, a "pedigree," or thoroughbred stock of extra early peas. It is the result of years of work in careful selection and skillful growing, to secure not only the earliest and the best-filled pods, but, at the same time, the most productive and uniform in ripening of extra early sorts. Careful personal selection has been made each season, for a number of years back, until its superiority in earliness, productiveness and uniformity in ripening has been absolutely fixed. Tests made the past season, with all the leading varieties of extra early peas, confirm conclusively that this pea is at least three to four days eariler than any other known variety, and that it is remarkable for its prolific qualities and evenness and uniformity of growth. The pods are well shaped and well filled, containing usually six to eight peas, of a beautiful green color, both peas and pods retaining their fresh green color longer after being picked than other kinds, this being a point of particular value when they are grown for shipping purposes.

In introducing this new pea, we believe that it is unquestionably the earliest and most profitable. extra early variety that can be planted, whethe for the market garden or shipping. We strongly recommend it to our customers, believing it will bring them increased profits from their pea crops, on account of its extreme earliness, well-filled pods, great productiveness, and especial value as a market sort. Pkt. 10c.; qt. 30c.; peck, $\$ 1.75$; bu. $\$ 6.00$.

\section{Wood's Improved POLE LIMA BEANS.}

This Improved Pole Lima has proven with us to be one of the best of the pole lima beans. It is earlier to mature than any of the other pole sorts, remarkably prolific, and continuous bearer, easy to shell, and will prove to be decidedly a money maker for the market-gardener. The pods are produced in clusters, and it is no uncommon thing at all to find clusters of these pods all ready to pull at one time. We strongly recommend it to our customers as a distinct and valuable improvement in pole lima beans. Pkt. 10c.; qt. 30c.; peck, $\$ 2.00$.

\section{DANISH BALL-HEAD CABBAGE.}

A remarkably solid heading variety, which originated in Denmark, and is grown in that country almost to the exclusion of other kinds. It has been found to succeed very twell in this country, and has proved a most valuable late variety. It forms round, very heavy, hard, compact heads, fine grained and of good quality, and it is particularly recommended for its keeping qualities, coming out of the pit in March or April almost as fresh as when put in. It has proven very popular wherever grown, and we recommend it to our customers for extended trial. Our seed is the true Danish grown seed. Pkt. 10c.; oz. 30c.; 1/4 lb. 80c.; lb. $\$ 2.50$.

ALBEMARLE CO., VA., March 10, 1902.-Your catalogue is always good, but I think you have it better than ever before, this year.

JOHN S. PARRISH.

EARLY CO., GA., Feb. 15, 1902.- - Your goods are giving great satisfaction, and we are having a trade beyond our expectations.

CITY PHARMACY.

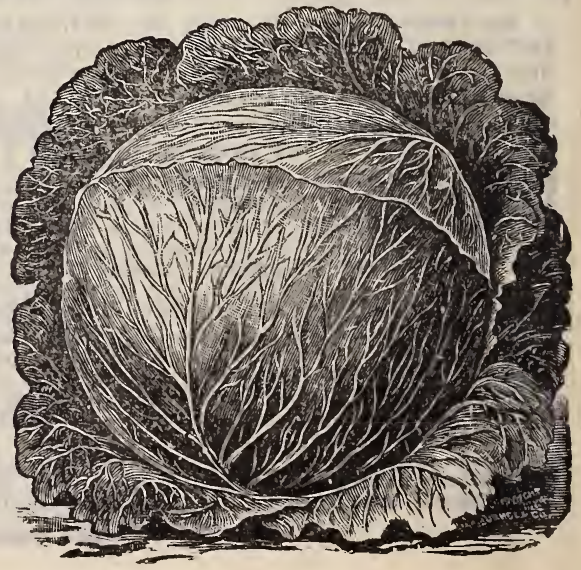




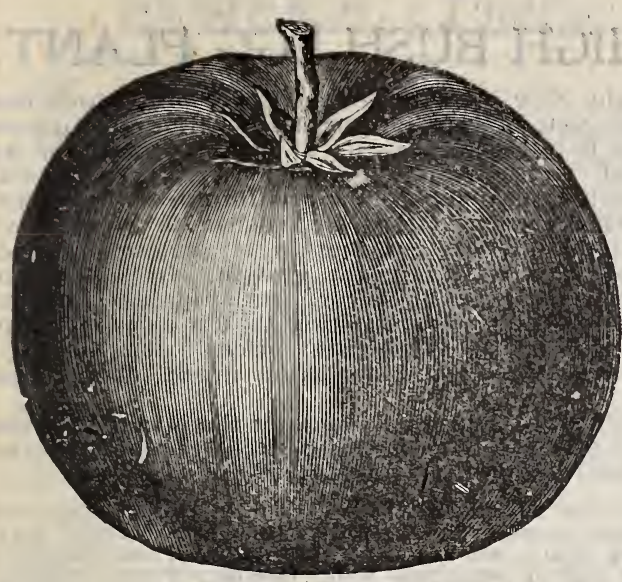

Sparks Earllana Tomato.

\section{SPARKS EARLIANA TOMATO}

A most valuable new introduction; which has unquestionably proven itself to be the earliest large smooth red tomato in cultivation. It is remarkable, too, for its wonderful productiveness, and we were very much impressed with its great value, as to its earliness, productiveness and uniformity of size, in tests made in our trial grounds last season. It is of very handsome shape, beautiful red color, very solid and of fine quality, containing very few seeds. It has received unanimous praise wherever it has been grown; reports claimed for it being from a week to twelve days earlier than any other known variety, and high authorities have pronounced it the most valuable tomato novelty of the past century. Pkt. 10c.; oz. 60c.; 1/t lb. $\$ 2.00$; 1b. $\$ 7.50$.

\section{PREIMO SWEET CORN.}

The earliest sweet corn of all. Five to seven days earlier than the Extra Early Adams, at the same time being very much superior in quality. It can be planted fully as early as the Adams, and makes a very good growth for so early a variety, and usually bears two well developed ears to a stalk. It is really a most distinct and valuable introduction, and we strongly recommend it, both for growing for market and for the private garden. Pkt. 10c.; pt. 20c.; qt. 30c.; peck, $\$ 1.50$.

\section{ZWAIM CUCUIMBER.}

A most excellent pickling cucumber, which was originally distributed by the United States Department of Agriculture, who obtained it from a section in Austria noted for producing remarkably fine pickles. We have grown this variety ourselves for the past two seasons, and consider it a valuable acquisition to our list of cucumbers. It is very prolific, produces uniform and short green cucumbers of a most desirable size and quality for pickling. It is medium early in maturity, of compact growth; fruit sets close to the hill, and the uniformity in size and appearance of the cucumbers is remarkable, even when the cucumbers are allowed to attain their full growth. While this variety is specially recommended for pickling purposes, still it also makes a desirable table sort, but we believe, from our experience with it, that its great value will be for growing as a pickle cucumber, and for this purpose we believe it will come into general cultivation. Pkt. 10c.; oz. 30c.; 1/4 lb. $90 \mathrm{c}$; lb. $\$ 3.00$.

\section{Longfellow Green Podded Bush Bean.}

A most valuable new round-podded snap bean. Has long green pods, always solid, delicious flavor, wonderfully tender and remarkably early. It is exceedingly prolific, and is really an ideal round-podded string bean. The pods are six and a half inches long, pale soft green in color, perfectly straight and round. It is extra early in maturity, being ready for use three or four days in advance of any other round-podded snap bean. In our tests at Hollybrook Farm this year, we were very much impressed by the superior qualities of this variety, and we strongly recommend it to our customers for general planting. Pkt. 10c.; qt. 30c.; peck, $\$ 1.60$; bu. $\$ 6.00$.

\section{New Round Podded Kidney Wax Bean.}

This is a decided improvement over the Wardwell's Kidney Wax Bean, in that its pods are round or cutshort, instead of flattish shaped like the Wardwell's. It is equally as prolific as Wardwell's, but, owing to its being a round cutshort wax bean, it will be found much more salable in our markets. The plants grow tall, strong and sturdy, with long, round, stringless pods of large size, very solid and full of meat, crisp and brittle. It is extra early in maturity, and must become very popular. We recommend it very highly. Pkt. 10c.; qt. $30 \mathrm{c}$.; peck, $\$ 2.00$; bu. $\$ 7.00$.

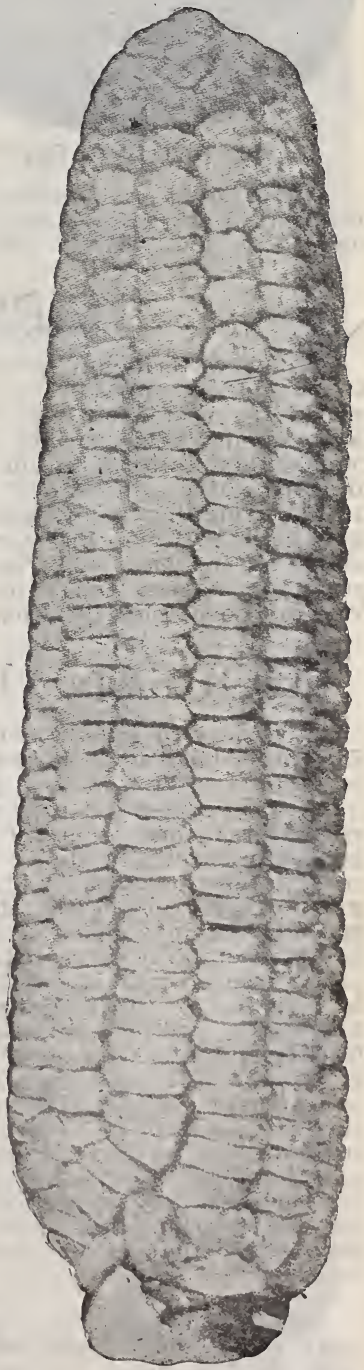

Premo Sweet Corn. 


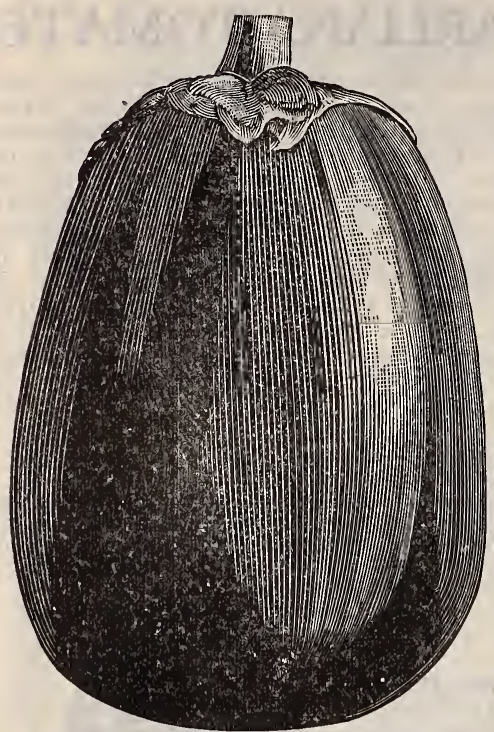

Florida High Bush Egg Plant.

\section{FLORIDA HIGH BUSH EGG PLANT.}

A new strain of the New York Improved Egg Plant, which has proven of the greatest value to our Southern truckers and shippers in the section where it has been grown. It is remarkable for its vigorous growth and productiveness, is very hardy, and will stand more cold weather than the New York Improved. The hot sun does not blight the blossoms, as is the case with some other sorts. It resists drought and wet weather to a wonderful degree, partly on account of its strong, upright growth. It is of large size, first-class shape, and superior flavor. Its shipping qualities are the very best, commission men reporting that it arrives in the very best condition, and brings the highest price in the Northern markets, keeping its freshness and condition much longer than any other variety.

The following certificate, signed by some of the largest Florida Egg Plant growers, gives full description and certifies to the splendid shipping qualities of this variety:

"The High Bush Egg Plant has been grown in this section for the past three or four years. The plant has a characteristic leaf, unlike any other egg plant we know of. It grows from three to four feet high, erect and sturdy, free from thorns. Fruit is large, oblong in shape and purple, though not so deep a color as the New York Improved. It stands the cold better, and is the only egg plant that stands shipping from this section to the Northern markets under almost all circumstances. We have realized good returns for this variety when all other varieties have been reported "arrived in bad condition.' We certainly would not plant any other variety."

$$
\begin{array}{ll}
\text { T. DENBY, } & \text { J. S, CROWN, } \\
\text { C. W. MCDONALD, } & \text { J. W. ALSOP, } \\
\text { E. P. LAVO, } & \text { H. G. CoLCLOUGH. }
\end{array}
$$

We strongly recommend the extensive growing of the Florida High Bush Egg Plant by our growers and shippers all through the South, believing it will prove to be a most valuable and profitable sort. Pkt. $10 \mathrm{c}$; oz. $40 \mathrm{c}$; $1 / 4$ lb. $\$ 1.00$; lb. $\$ 3.50$.

\section{HARRIS EARLIEST WATERIMELON.}

A new watermelon, which is unquestionably the earliest watermelon on the market, being earlier and decidedly superior as a shipping and market melon to the Dark Icing, which hitherto has been one of the best early melons, but, owing to its tender rind, is not a good shipping sort. This melon is also remarkable for its productiveness, and it will outyield any early melon in cultivation. It is remarkably uniform in shape, mottled skin, with green and white stripes, making a most beautiful and attractive appearance. The flesh is red, sweet, juicy and crisp. The seeds are black. It produces melons weighing from twelve to forty pounds, the average being fifteen to twenty pounds. Growers who have planted this variety have been remarkably well pleased with it, and are unanimous in its praise as the best early watermelon in cultivation. We specially recommend it to melon growers who grow for market and shipping. It will also be found a most valuable variety for the earliest melon for home use. Pkt. $10 \mathrm{c}$; oz. $15 \mathrm{c} . ; 1 / 4$ lb. $35 \mathrm{c}$.; lb. $\$ 1.00$.

\section{THOUSAND-HEADED KALE.}

A variety of kale which comes to us from Norther' Europe, where it is largely used for sheep pasture. It is claimed to be very much superior, both in yield and quality, to rape, and is coming into very general use wherever it has been introduced. It has not been very, generally grown in this country as yet, but wherever tried it has been fully demonstrated that it is a great green food for cattle, hogs, sheep and poultry. spreads out in a mass of matted, curled leaves somewhat resembling rape, but is very much more prolific, and produces more food than the Dwarf Essex Rape. In this section it can be sown either in the spring or fall at the rate of 3 or 4 lbs. per acre. When sown in the fall, the plants will keep green throughout the winter and make fine pasturage in the spring; and will also make a fine green fertilizer crop for plowing under in the early summer. We strongly recommend this new introduction to our customers, believing it will prove a most valuable addition to our list of forage crops. We also suggest that experiments be made of sowing it to use as a spring and winter salad, as it may prove desirable for that purpose also. Oz. 10c.; 1/4 lb. 15c.; lb. $50 \mathrm{c}$.

MONTGOMERY CO., VA., July 15, 1902. - You must push the Claudit Peas, but the wonder of the neighborhood is the Bliss Everbearing Pea. They are large, sweet, and are still bearing. (Judge) G. E. CASSEL.

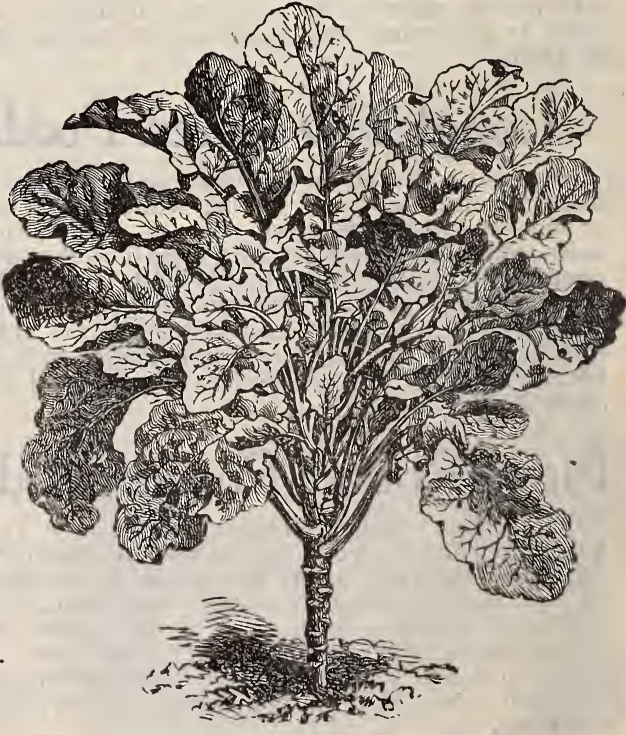

Thousand-Headed Ka!e. 


\section{EUREKA CORN.}

This corn is a decided improvement on the famous Cocke's Prolific, from which it originated. The ears are much larger and longer, frequently measuring from twelve to fourteen inches long. It is a pure white, medium hard corn; fine keeper; an excellent corn for market or milling. Also a fine corn for ensilage. Has from two to three ears to the stalk; on good land will yield from 60 to 135 bushels to the acre. Grows from 12 to 16 feet high. Will weigh about sixty pounds to the measured bushel. This corn, like all two or three-eared sorts, will do best on good land, and is especially adapted for bottom lands. For this class of soils we believe unquestionably that this is the largest yielding white corn in cultivation. The following letter is from one of our largest Virginia farmers, who planted over one hundred acres in Eureka Corn the past season:

BUCKINGHAM Co., VA, Nov. 15, 1902.

"I think the Eureka Corn is the best corn I have ever grown or seen. I cultivated about one hundred acres this season, and from the same gathered 1,400 barrels $(7,000$ bushels). The crop was the admiration of all who saw it, from all sections of the State. Farmers will not make any mistake by planting their entire crop of this corn.

A. J. TERRELL.

Price of the Eureka Corn, pkt. 10c.; qt. 25c.; peck, 75c.; bu. $\$ 2.00$. Special price on large lots.

\section{IRON COW PEA.}

A new variety of cow pea, which is remarkable for its vigorous growth and disease-resistant qualities. It will retain its leaves and foliage better and longer than any other kind with which we have had experience, a most valuable consideration where the crop is sown for forage.' It is also specially valuable, in that it is entirely resistant to the attacks of the wilt fungus, the Root Knot Worm or Nematode, and will produce a good crop on land where other varieties will fail to make a crop. This is of the greatest value to some sections of the South, where the parasites above mentioned are widespread, causing the condition of the land known as "pea sickness."

Prof. W. A. Orton, Assistant Pathologist of the United States Department of Agriculture, says:

"I have found no instance where the fron Pea has failed to succeed, even on land where other peas have not been a success, and its general use will be of great value to agriculture in the South. It is particularly important that no other variety of Cow Pea but the Iron should be planted on land infected with root-knot worms, as the planting of a susceptible variety will increase the number of parasites in the soil to such an extent as to be a serious injury to a cotton crop planted on that land the next year. The Iron Pea can be planted safely in such places, and is highly recommended for all pea-sick lands, for use where other varieties do not succeed."

Mr. T. S. Williams, a large pea grower in South Carolina, says in regard to this pea:

"The Iron after another season's experiment has more than fully substantiated the claims made for it My land was so badly infected with wild fungus and nematode, before I got this pea, that I made practically no peas. This year I will make as a side cropthat is, none planted as a regular field crop, but planted between corn and asparagus rows and in orchard-nearly one thousand bushels."

Even if this pea did not have the above remarkable qualities to recommend it, it would be a most valuable variety, and a variety that is destined to come into general use. It is medium early to mature, and is therefore adapted for sowing in the North. It is very prolific of peas, and its vines keep green and have considerable leaves when other varieties will be practically dead, with the leaves all shed and the vines rotten.

We strongly recommend this new pea for all sections of our country. Pkt. 10c.; at 20c.; peck, $\$ 1.00 ;$ bu. $\$ 3.00$. Special prices quoted on large lots.

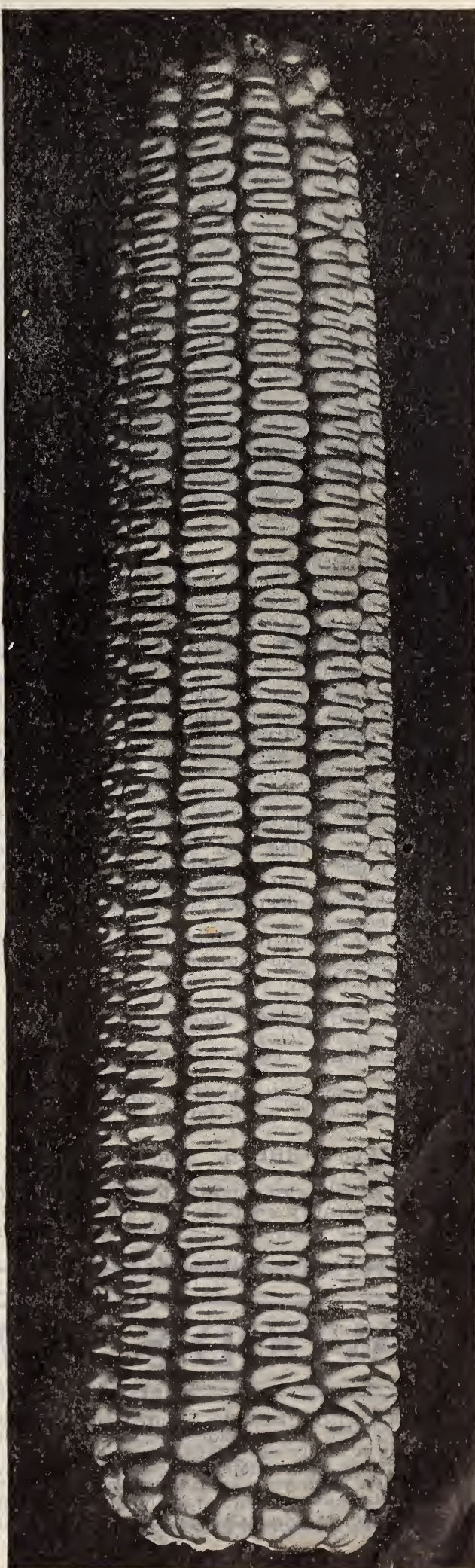

Eureka Corm 


\section{WOOD'S SELECTED SEED POTATOES.}

Culture.-In order to have the best success in growing early potatoes, it is best to plant as early in the spring as the ground can be made ready. For late potatoes, the seed can be planted in June July and August. We will carry potatoes in cold. storage, so as to keep them in splendid condition for supplying our customers at that time. Potatoes are usually planted in rows three feet apart, and the sets one foot apart in the row. It is always best to plant potatoes on land that has been heavily manured the previous season; or, if manure is used at the time of planting, it should be well rotted and thoroughly mixed with the soil, in order to avoid scab on the potatoes. Good soil is necessary to produce a good crop of potatoes. If the ground is not rich enough, a good application of Mapes' Potato Manure or Standard Potato Fertilizer should be used. From four to five hundred pounds is the quantity usually used, although the use of one thousand pounds to the acre is a very common occurrence.

Insect Remedies for Potatoes.-The Colorado Potato Bug is the principal enemy of potatoes.

The most popular remedy for same is Paris Green mixed with land plaster and applied dry while the dew is on the plants, or applied in a liquid state with whisk broom or brush. One pound of Paris Green mixed with one hundred pounds of land plaster is the quantity usually applied, or mixed with water, one pound of poison to two hundred gallons of water is a good mixture. When mixed with water, the mixture must be kept in a constant state of agitation, else the poison will settle, and the liquid from the bottom of the cask will be so strong as to do serious injury. Slug Shot is also largely used and with very good results.

PRICES OF. POTATOES FLUCTUATE. The prices quoted here are about as we expect them to be, but we will take pleasure in quoting prices at any time upon request, or will fill any orders entrusted to us at lowest prices at the time the order is received.

\section{VIRGINIA SECOND CROP SEED POTATOES.}

We have secured a large stock of these potatoes, personally selected in the fields, from the.very best crops grown in this section, and the quality and productiveness of the stock secured is unsurpassed.

Virginia-grown second Crop Seed Potatoes are unquestionably superior to those grown farther South, being entirely free from scab, smoother, and of much better quality. The Virginia seed, too, is the true second crop seed, and not, as is frequently offered from other sections, early varieties of the previous year's growing planted late. The true Second Crop Potatoes are the result of growing two crops in the same year, the first crop being usually grown from Maine or Northern-grown seed, and the seed potatoes selected from this crop planted again in July or August.

Wherever planted, our Virginia Second Crop Seed Potatoes have unquestionably proved their superiority over Maine and Northern-grown Seed both in earliness and productiveness, and while hitherto their use has been principally confined to large truckers and gardeners throughout the South, they are now being quite generally used in sections where they have been tried throughout the North. We believe they are destined to supersede very largely both Maine and Northern-grown Seed all along the Atlantic coast.

We have the following kinds in stock. Full descriptions of all varieties will be found under the heading: of "Maine and Northern-Grown Seed Potatoes."

WOOD'S EARLIEST. Peck, 50c.; bu. $\$ 1.40$; bbl. about $\$ 3.25$.

RED BLISS TRIUMPH. Peck, 50c.; bu. $\$ 1.30$; bbl. about $\$ 3.00$.

THOROUGHBRED. Peck, 50c; bu. \$1.30; bbl. about $\$ 3.00$.

BOVEE. Peck, 5.0c.; bu. $\$ 1.30$; bbl. about $\$ 3.00$.

EARLY ROSE. Peck, $40 \mathrm{c}$; ; bu. $\$ 1.20$; bbl. about

$\$ 2.75$.

WHITE BLISS, or PRIDES. Peck, 50c.; bu. $\$ 1.40$; bbl. about $\$ 3.10$.

CROWN JEWEL. Peck, 40c.; bu. $\$ 1.20 ;$ bbl. about $\$ 2.75$.

POLARIS, or PURITAN. Peck, 40c.; bu. $\$ 1.20$; bbl. about, $\$ 2.75$.

NEW QUEEN. Peck, 40c.; bu. $\$ 1.30$; bbl. about $\$ 3.00$.

FULL-SIZED BARRELS. Remember, we always ship in full-sized barrels (flour barrel size), and not in the under-size truck barrels or cloth-head barrels, which are frequently used. Our potatoes are not only of superior quality, but our mode of putting them up makes them much more presentable, and the quantity contained in the barrel will also average considerably more than in the truck barrels ordinarily used. Special prices quoted on large lots of potatoes.

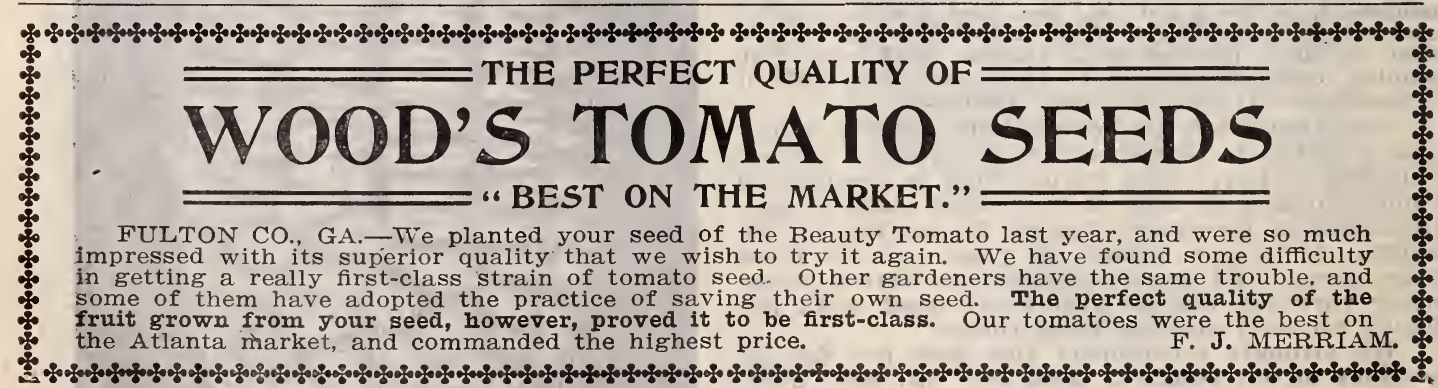




\section{MAINE AND NORTHERN GROWN SEED POTATOES.}

Specially grown for us for seed purposes in the best potato districts in this country. Our Northern - grown stocks are grown principally in Maine, while our Early Ohios are grown in the famous Red River district, noted for producing the finest Early Ohio potatoes in the country. All the stocks of potatoes which we have supplied in the past have given the most satisfactory results, causing our trade to increase very rapidly, and we sell Seed Potatoes in very large quantities to the most successful potato growers all throughout the South.

EXTRA EARLY WHITE ROSE.

This new potato originated with one of the most successful and experienced growers in Aroostook county, Maine. It is extra early in maturity, yielding large crops of perfectly smooth, white potatoes, of most superior table and market quality. In shape it is similar to the old Early Rose, but being a white potato and superior in yield and table qualities, makes it an ideal extra early sort. We believe unquestionably that this new potato will prove to be even more popular than the old Early Rose was when it was first introduced. Price: Peck, 60c.; bu. $\$ 1.60 ;$ bbl. about $\$ 4.00$.

JUNIOR PRIDE. This new extra early potato continues to maintain its pre-eminence as the earliest variety in cultivation. A great advantage in this extra early potato is its superior quality, and the fact that, being a pure white potato, it proves a so much better seller, and so much more desirable potato for shipping than the Triumph or other red varieties. It is round in shape, similar to Wood's Earliest, but skin pure white, whereas the Wood's Earliest has a slight pinkish tinge on the skin when ripe. We feel sure that this and our New Extra Early White Rose, which we offer for the first time this year, will prove to be most popular and profitable varieties. Price of Maine-grown seed: Peck, 60c.; bu. $\$ 1.50$; bbl. about $\$ 3.75$. Special prices on large lots.

WOOD'S EARLIEST. This variety continues to give the most unbounded satisfaction as an extra early potato, and is increasing in popularity throughout the South. It is extra early in maturity; very productive. The potatoes are of beautiful shape, being nearly round, with very shallow eyes. flesh pure 'white, skin white with slight pink tinge. It is of excellent table qualities, a heavy vielder and produces nearly all large potatoes. We strongly recommend it to truckers and market-gardeners as one of the best extra early kinds in cultivation. Peck, 60c.; bu. $\$ 1.50$; bbl. about $\$ 3.60$.

EARLY OHIO. Our stock of these is of extra fine quality, grown especially for seed purposes in the Red River district, in the North, famous for its superior Early Ohio potatoes. It fully maintains its great popularity as an extra early variety, giving entire satisfaction wherever grown. The tubers are oval, oblong, round at the seed end. An excellent keeper, very productive, of fine quality. Pk. 50 c.; bu. $\$ 1.40$; bbl. about $\$ 3.25$.

EARLY HARVEST. A splendid Maine-grown extra early potato. Produces large crops, and makes a very attractive marketable size potato. The quality is excellent, cooking white and mealy; a splendid general crop early variety. Peck, 50c.; bu. $\$ 1.40$; bbl. about $\$ 3.40$.

TRIUMPH, or RED BLISS. An extra early potato, round in shape, pink skin, white flesh, and of handsome appearance. This seems to be specially adapted to Southern soil and climate, and is a great favorite with Southern truckers. Is also largely grown for Second Crop, and sold in Northern markets for New Bermuda Potatoes during the late winter and early spring. Peck, 60 c.; bu. $\$ 1.50 ;$ bbl. about $\$ 3.50$.

WHITE BLISS, or PRIDE OF THE SOUTH. An excellent extra early potato, shape similar to the Red Bliss' Triumph, color, white with pink eyes. Early and popular with market-gardeners. Peck, 60c.; bu. $\$ 1.50$; bbl. about $\$ 3.50$.

THOROUGHBRED. A splendid early variety which has given the very best satisfaction to our potato growers. It is similar to the old Rose in shape, and a decided improvement. It is of long shape, pink skin, extra fine quality, and very productive. Peck, $50 \mathrm{c}$; bu. $\$ 1.40 ; \mathrm{bbl}$ about $\$ 3.40$.

BOVEE. An extra early potato, somewhat similar to Beauty of Hebron. Fine growth; dwarf and stocky. The potatoes are white, with pinkish skin; smooth, handsome, fine quality, yielding heavily. Very popular wherever grown. Peck, 60c.; bu. $\$ 1.50$; bbl. about $\$ 3.50$.

NEW QUEEN. One of the largest yielding of the early kinds. Vigorous grower; produces but very few small potatoes. A good general cropper. White skin. An attractive market potato, of superior table qualities. Peck, 50c.; bu. $\$ 1.40$; bbl. about $\$ 3.40$.

HOULTON EARLY ROSE. This is an improved strain of the original Early Rose, specially grown for seed purposes in the State of Maine. Peck, 50c.; bu. $\$ 1.40$; bbl. about $\$ 3.40$.

BEAUTY OF HEBRON. This is a very superior table variety. It is about a week later than the Early Rose, but claimed to be more productive. It is a white fleshed potato, and of most superior flavor, and very desirable for private growers and the home market. Peck, 40c.; bu $\$ 1.20$; bbl. about $\$ 2.75$.

EARLY ROSE. An excellent quality of this old variety, though not quite equal in crop results to our Houlton Maine-grown stock. Peck, 40c.; bu. $\$ 1.20$; bbl. about $\$ 2.75$.

PURITAN, or POLARIS. A splendid early variety, white and fine, very prolific, yielding large crops of handsome potatoes of most superior table qualities. Peck, 50c.; bu. $\$ 1.40$; bbl. about $\$ 3.40$. 


\section{MEDIUIM AND LATE POTATOES-Nortnern Grown.}

RICHMOND BELLE. A handsome second early white skinned variety of our own introduction. It grows to a large size, and ripens two to three weeks later than the Early Rose, but yields much more largely. It makes a splendid winter variety if planted during June or July. It cooks dry and mealy, and is of excellent flavor. Peck, 50c.; bu. $\$ 1.25$; bbl. about $\$ 3.00$.

CARMAN NO. 3. A splendid new second early variety, which originated as a seedling with Mr. E. S. Carman, editor of the "Rural New Yorker." It is of perfect form, even in dry seasons, and grows to a large size, almost every potato being of uniform size and shape. It has but few eyes, and they are very shallow. The skin and flesh are extremely white, no hollow or dark parts, and its cooking qualities are exceptionally fine; a remarkably handsome potato and enormously prolific. In many respect this potato resembles the Rural New Yorker No. 2, but is destined to supersede that well-known popular variety. Peck, 50c.; bu. $\$ 1.40$; bbl. about $\$ 3.25$.

MONEY MAKER. A long, white potato, similar to the old Burbank, but superior to that variety, both in quality and yield. It makes a very attractive potato, either for market or table purposes, and has given entire satisfaction wherever grown. Peck, 50c.; bu. $\$ 1.25$; bbl. about $\$ 3.00$.

GREEN MOUNTAIN. A large, handsome, oval, white potato. Medium late. One of the finest eating potatoes known to the trade. Shallow eyed, fine textured, well flavored, and a most prolific yielder. It is not susceptible to disease, and is fast becoming the standard white potato for late planting in this country. Peck, 50c.; bu. $\$ 1.25 ; \mathrm{bbl}$. about $\$ 3.25$.

PEERLESS. A favorite general crop variety; specially adapted for light and medium soils. It is round in shape. One of the largest yielding kinds in cultivation, but for table qualities is not considered quite as good as some other kinds. Peck, 40c.; bu. $\$ 1.20$; bbl. about $\$ 2.75$.

RURAL NEW YORKER, No. 2. One of the best yielding late potatoes. Free from blight or rot. Color white; form

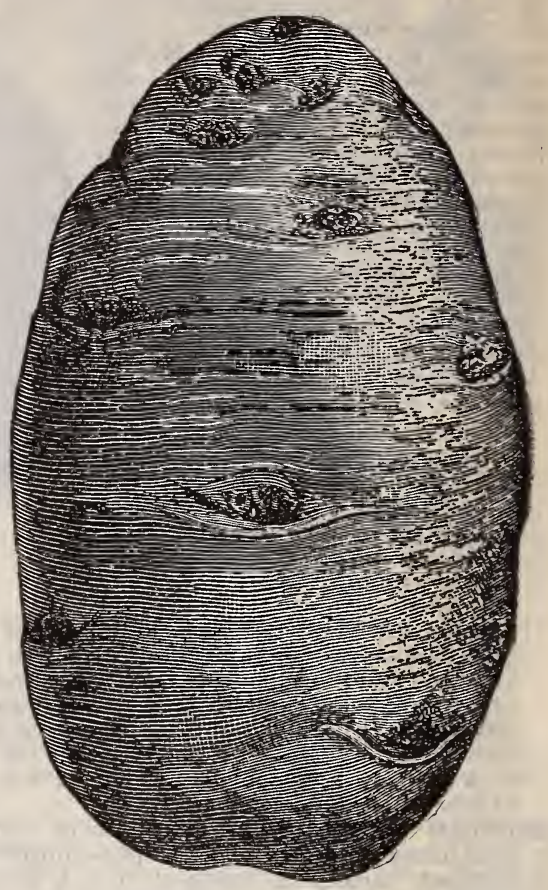

Money Maker Potato. round or oval; smooth skin, shallow eyes, and an excellent market potato. Peck, 40c.; bu. \$1.25; bbl. about $\$ 2.75$.

EMPIRE STATE. A long, white potato, somewhat resembling the Burbank, but not quite so uniform in shape. A great yielder, of excellent quality, and good market potato. One of the best for late or general crop purposes. Peck, 40c.; bu. $\$ 1.20$; bbl. about $\$ 2.75$.

BURBANK. An old standard variety, which continues in good demand. Long, white; good table qualities, and well adapted for heavy soils. Peck, $40 \mathrm{c}$; ; bu. $\$ 1.20 ;$ bbl. about $\$ 2.75$.

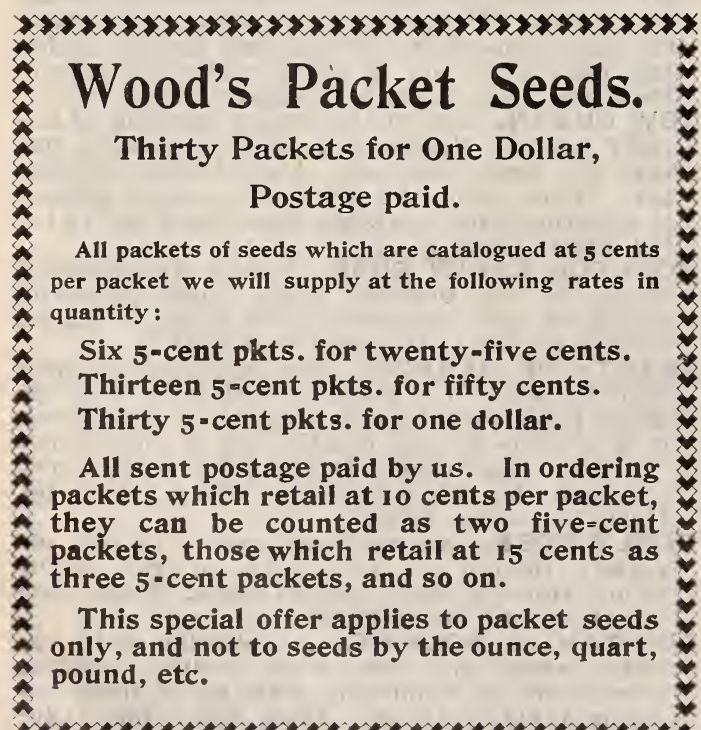

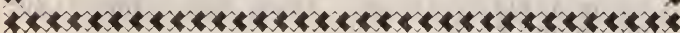

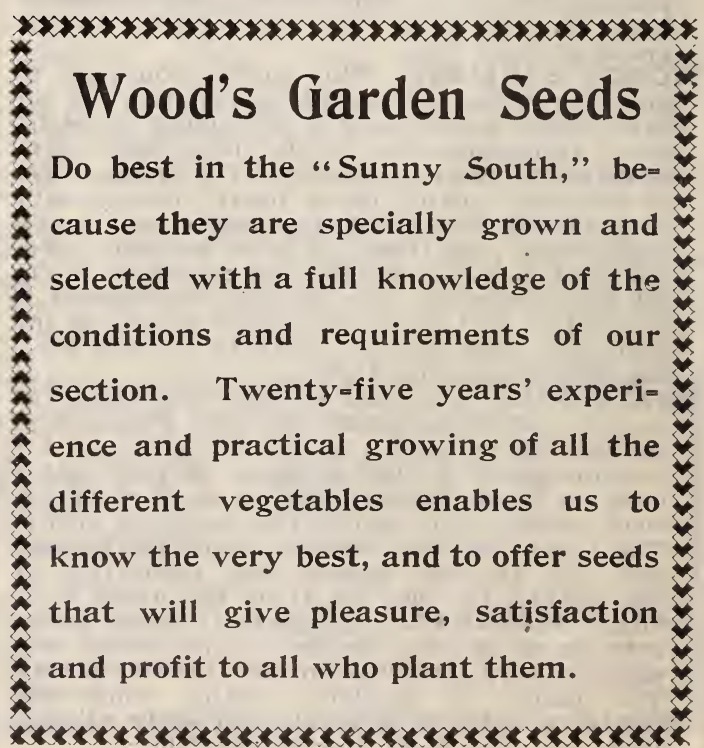




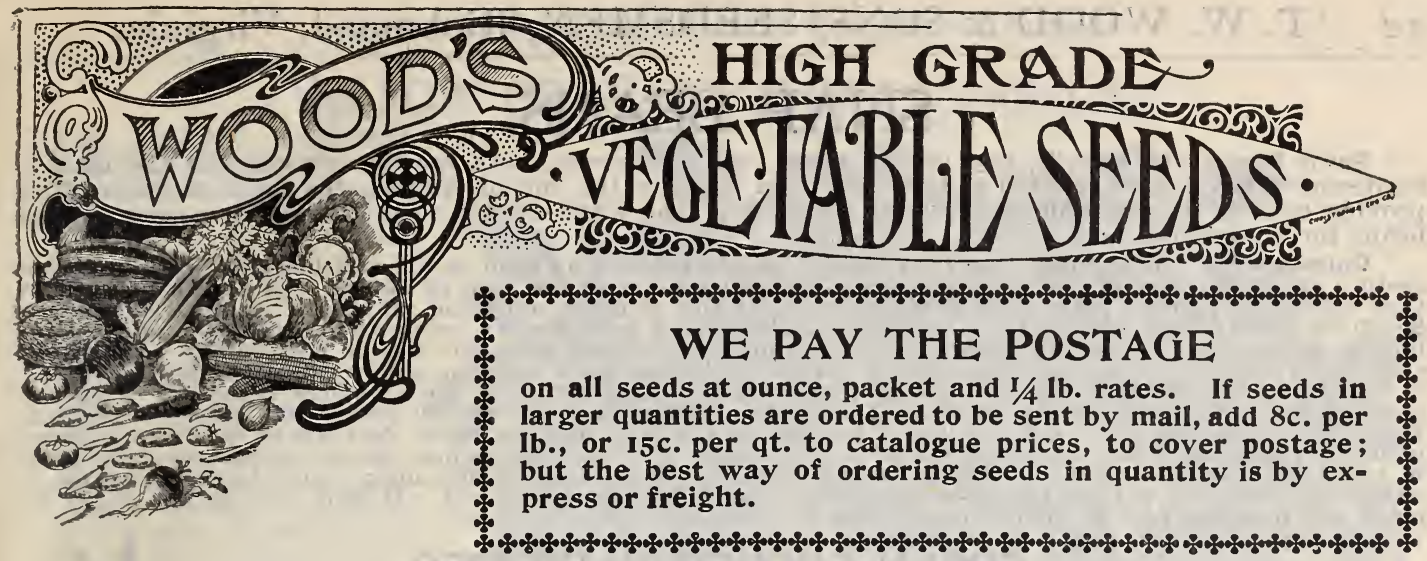

\section{ARTICHOKES.}

Culture-The seed of the Green Globe Artichoke can be sown in hot-beds in February, and trans planted in May, or can be sown in the open ground in April in rows fifteen inches apart and one inch deep, thinning out to four inches, and transplanting the following spring to rows three feet apart and two feet between the plants. Give slight protection in winter with litter or manure. The Jerusalem Artichokes are planted and cultivated same as potatoes.

GREEN GLOBE. Entirely different from the Jerusalem, or tuberous-rooted artichoke, in that it is not grown for its tubers, but for the undeveloped flower heads, which are cooked like asparagus, and make a most tender and excellent vegetable. The part eaten is the petal of the undeveloped flowerhead. Take up the petal between the fiinger and the thumb, and force the fleshy, nut-like substancẹ out between the teeth. Can be eaten with butter, sause or French dressing. Use this vegetable once, and you will always want it. It is hardy in Virginia and States farther south, and should be much more largely grown than at present. Like asparagus, when once planted it lasts for several years, which is a strong point in its favor. Pkt. $10 \mathrm{c}$; ; oz. $30 \mathrm{c}$; $1 / 4$ lb. $80 \mathrm{c}$; ; lb. $\$ 2.75$.

JERUSALEM ARTICHOKE. This variety is not grown from seed, but from roots or tubers. They are sometimes used as a vegetable and for pickling, but their greatest value is for feeding to stock, being particularly desirable for hogs, making an enormous yielding, healthy and nutritious feed. Plant and cultivate same as potatoes. Fuller information is given under the head of "Farm Seeds." Qt. 15c.; peck, 50c.; bushel, $\$ 1.25$. Special prices on large lots.

\section{ASPARAGUS.}

Our Asparagus seed is southern grown, saved from healthy, vigorous crops, entirely free from the disease which has in recent years infested the crops grown in the North. Once planted, asparagus will, with proper care and attention, last for ten or fifteen years. It is a most excellent and profitable vegetable.

Culture.-Asparagus will succeed well in any good, rich soil, but a light, warm soil which has been heavily manured for previous crops, is best. The quickest way to grow asparagus is to set out, either in the fall or spring, strong roots, preferably two year old, but one year old roots give very good results. To prepare permanent beds, plow or dig out trenches eighteen inches wide and six to ten inches deep, making the trenches four or five feet apart. In the bottom of the furrow scatter Wood's Pure Animal Bone, and also an application of well-rotted manure, which dig lightly in and mix with the soil, and then set the plants fifteen inches apart in the rows. Spread out the roots carefully and cover with soil two inches deep, and on the approach of winter cover with manure, which fork in early in the spring, and apply a dressing of pure animal bone or kainit. If white asparagus is desired, the second spring after planting, earth up in beds eighteen inches above the roots, to blanch the asparagus as it grows. If green asparagus is desired, it is not necessary to earth up so deeply, or to make the rows more than three feet apart. Do not cut too late in the spring, as it is liable to exhaust the plants. During the winter or early spring, cut or burn off the growth, run the plow over the bed to throw the earth down, and apply manure or ground bone, or both, mixing same in with the soil. To make white asparagus, the beds must be freshly and lightly earthed up each spring just before the growing season commences. To raise asparagus roots from seed, sow the seed thinly one inch deep in rows fifteen inches apart. Keep clean of weeds, and thin o the plants to four inches apart. When one or two years old set out in permanent beds.

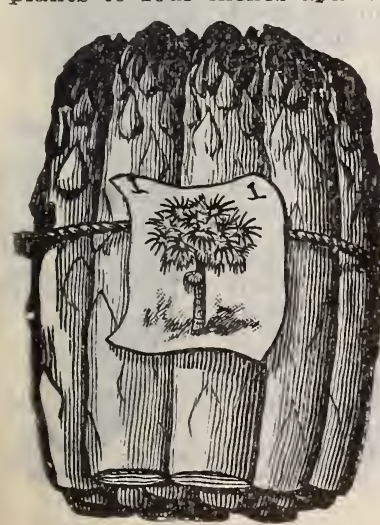

Palmetto Asparagus.
GIANT ARGENTEUIL ASPARAGUS. This variety was originally a selection from imported French Argenteuil stock, but has been both acclimated and improved, and is very much superior to the original stock. It has been grown for several years by some of the leading and most successful truckers near Charleston, S. C., and is pronounced far superior to any other variety in earliness, productiveness, and size of stalks produced, and it always sells at a higher price in Northern markets. Pkt. 5c.; oz. 10c.; 1/4 lb. 20c.; lb. 60c. Special prices on large lots.

CONOVER'S COLOSSAL. An old standard. Produces more stalks to the root than any othęr kind. Pkt. 5c.; oz. 10c.; 1/1 1b. 15c.; lb. 30c.

PALMETTO. A favorite with truckers. Not quite as prolific as Conover's, but is a little earlier, and makes larger stalks. Pkt. 5c.; oz. 10c.; $1 / 4$ lb. 15c.; 1b. 40c. Special prices quoted in quantity.

ASPARAGUS ROOTS.-Conover's Colossal. Two-year-old roots, $75 \mathrm{c}$. per $100 ; \$ 4.00$ per 1,000 .

PALMETTO. Two-year-old roots, 90c. per $100 ; \$ 4.50$ per 1,000 . Special prices quoted on large lots.

ASPARAGUS KNIVES.-30c. each; if by mail, $40 \mathrm{c}$.

ASPARAGUS BUNCHERS. $-\$ 1.75$ each. 


\section{SNAP BEANS.}

Snap Beans are usually one of the most profitable crops, both for the trucker and the market gardener. They can be planted at intervals from April to the end of August, the late plantings often proving equally as profitable as the early plantings. The white-seeded sorts also make excellent dried beans for winter use.

Culture.-For the earliest crop they should be planted just as soon as the weather gets warm-in this section about the first of April; further South, from the 1 st to the 15 th of March. To have a succession they should be planted every two weeks throughout the summer until the middle of August, or further South as late as September 20 th. Late snaps make a very satisfactory crop, and should be much more largely grown than at present. Beans do best on moderately stiff soils, but will do well on any good loamy soil. They do not require heavy manuring. If the soil contains a fair amount of vegetable matter, apply a fertilizer containing potash and phosphoric acid, the plant securing the ammonia necessary from the atmosphere. The fertilizer should be well mixed in the furrow with the soil before the beans are planted. For field culture, beans should be planted in rows two and a half to three feet apart, and about three For field culture, beans should be planted in rows two and a half to three feet apart, and about three in small gardens, the rows may be two feet apart. Un to the time of blooming, cultivate often, but never when the vines are wet, as the pods and leaves would become discolored. It will require one quart to plant one hundred feet of drill; one and a half bushels to plant an acre.

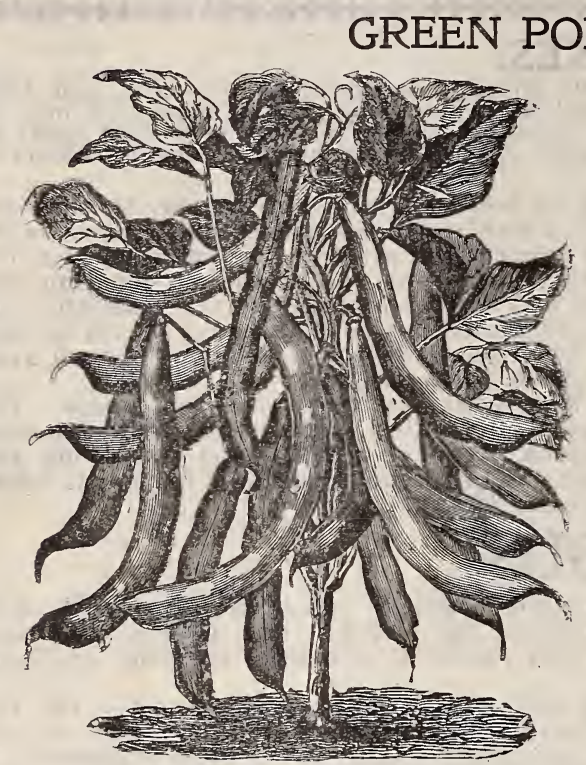

Wood's Earliest Red Speckled Valentine.

LONGFELLOW. A new green-podded bush snap bean. Remarkably early, exceedingly prolific; very long green pods, of delicious flavor. For full description, see "New Varieties of Special Merit," page 5. Pkt. 10c.; qt. 30c.; peck, $\$ 1.60$.

WOOD'S EARLIEST HARDIEST. Recommended particularly for its earliness and hardiness. At the same time, its productiveness, tenderness and excellent table qualities make it a desirable sort for main crop and late planting. It makes a flat-podded snap, and is very prolific. The beans are white, and make excellent dry beans for winter use. It will stand a light frost without injury, and can be planted earlier than other sorts. Pkt. 5c.; qt. 20c.; peck, $\$ 1.10$; bu. $\$ 4.00$.

EARLY MOHAWK, or BROWN SIX WEEKS. First early, hardy, long green pods, broad, thick and flat. Pkt. 5c.; qt. 20c.; peck, $\$ 1.00 ;$ bu. $\$ 3.75$.

EARLY SIX WEEKS. Extra early, green podded, hardy. Popular with private gardeners as a first early. Pkt. 5c.; qt. 20c.; peck, \$1.00; bu. $\$ 3.75$.

WOOD'S EARLIEST RED SPECKLED VALEN. TINE. Earlier and more productive than the ordinary strains of Red Speckled Valentine. Pods round and thick. Flesh finest quality; and unequalled in uniformity of ripening. One of the most profitable sorts for private and market gardeners. Pkt. 5c.; qt. 20c.; peck, $\$ 1.00$; bu. $\$ 3.75$. Special prices on large lots.

\section{GIANT STRINGLESS GREEN}

$P O D$. This is a decided improvement over the Red Speckled Valentine Bean, and Burpee's Stringless. It is ready for market, with a more prolific crop of pods, several days earlier. The pods are one-third larger, averaging five to six inches in length, and they are always absolutely stringless, round, full and fleshy. It is very prolific, and surpasses other varieties in crispness and flavor. Our trial-ground tests on our Hollybrook Farm the past year showed this to be a most superior variety. Pkt. 5c.; qt. 20 c.: peck, $\$ 1.10 ;$ bu. $\$ 4.00$.

BURPEE'S STRINGLESS GREEN POD. A very early variety, having long, straight, round, fleshy pods, which are free from strings. Desirable for either home or market garden. Pkt. 5c.; qt. 20 c.; peck, $\$ 1.10$; bu. $\$ 4.00$.

EXTRA EARLY REFUGEE. Has all the good qualities of the wellknown Refugee, but is ready for the market ten days earlier. An immense yielder, and sure to produce a crop either in a wet or dry season. A fine shipper, and fast becoming one of our most popular round green-podded snaps for both spring and summer planting. Pkt. 5c.; qt. 20c.; peck, $\$ 1.00$; bu. $\$ 3.90$.

BEST OF ALL. Popular in the far South, but in this section does not succeed so well. Pods green, thick, semi-round. Good table qualities, and second early in maturity. Pkt. 5c.; qt. 20c.; peck, $\$ 1.10$; bu. $\$ 4.00$.

REFUGEE, or 1,000 TO 1. This is really one of the best snaps for general use or for main crop. It is enormously productive. The snaps are round-podded, tender and of excellent table qualities. Later than the early kinds, but continues in bearing much longer. Pkt. 5c.; qt. 20c.; peck, $\$ 1.00$; bu. $\$ 3.65$.

WOOD'S BACON BEANS. Thoroughly distinct and hardy. Can be planted in January or February. Excellent for use as a green shelled bean with bacon. Pkt. $10 \mathrm{c}$.' pt. $20 \mathrm{c}$; ; qt. $35 \mathrm{c}$.; peck, $\$ 2.00$.

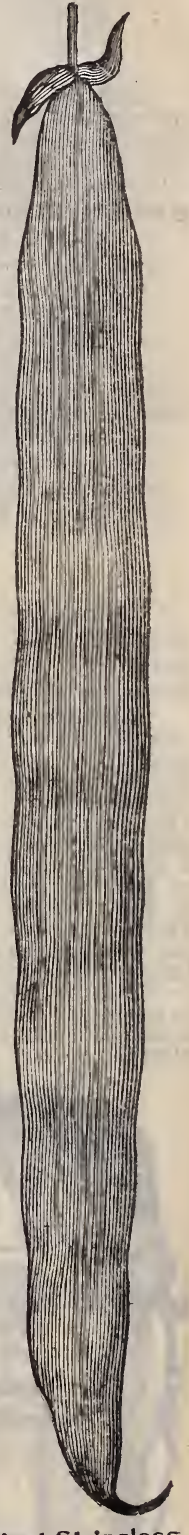

Glant Stringless Green Poo. 


\section{YELLOW OR WAX-PODDED VARIETIES}

NEW ROUND PODDED KIDNEY WAX. For full description of this splendid new extra early round pod wax bean, see "Seeds of Special Merit," p. 5 . Pkt. 10c.; qt. 30c.; peck, $\$ 2.00$; bu. $\$ 7.00$.

JONES' STRINGLESS WHITE WAX. A new white-seeded wax bean, claimed to be absolutely rust-proof. It is a roundpodded cut-short snap; solid; of a delicate light yellow color, stringless and brittle. In habit it is dwarf and stocky, and bears abundantly. Pkt. 10 c.; qt. 35 c.; peck, $\$ 1.75$; bu. $\$ 6.00$.

CURRIE'S RUST - PROOF WAX. One of the earliest of the wax sorts. Vines strong, robust and up-

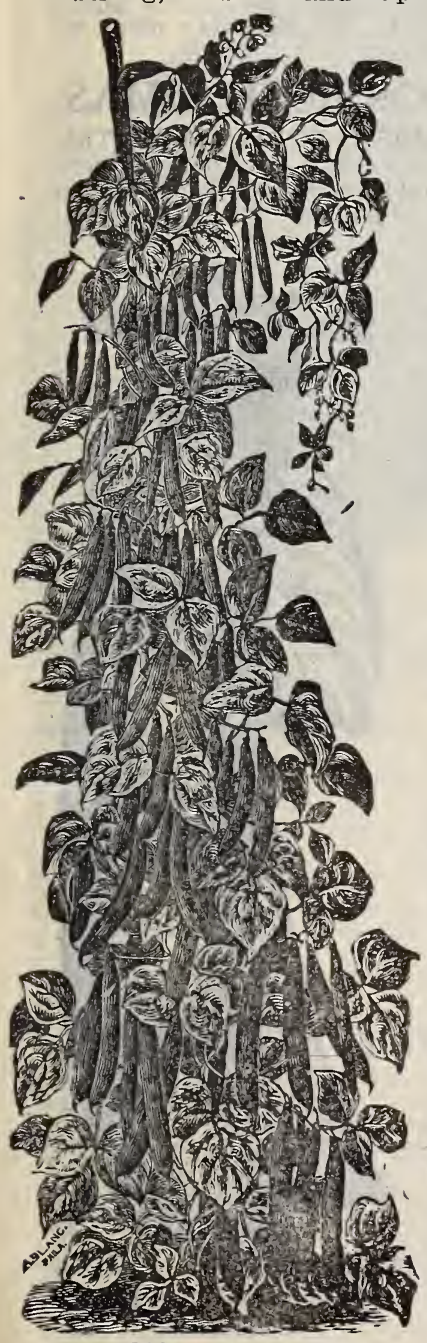

Old Homestead.

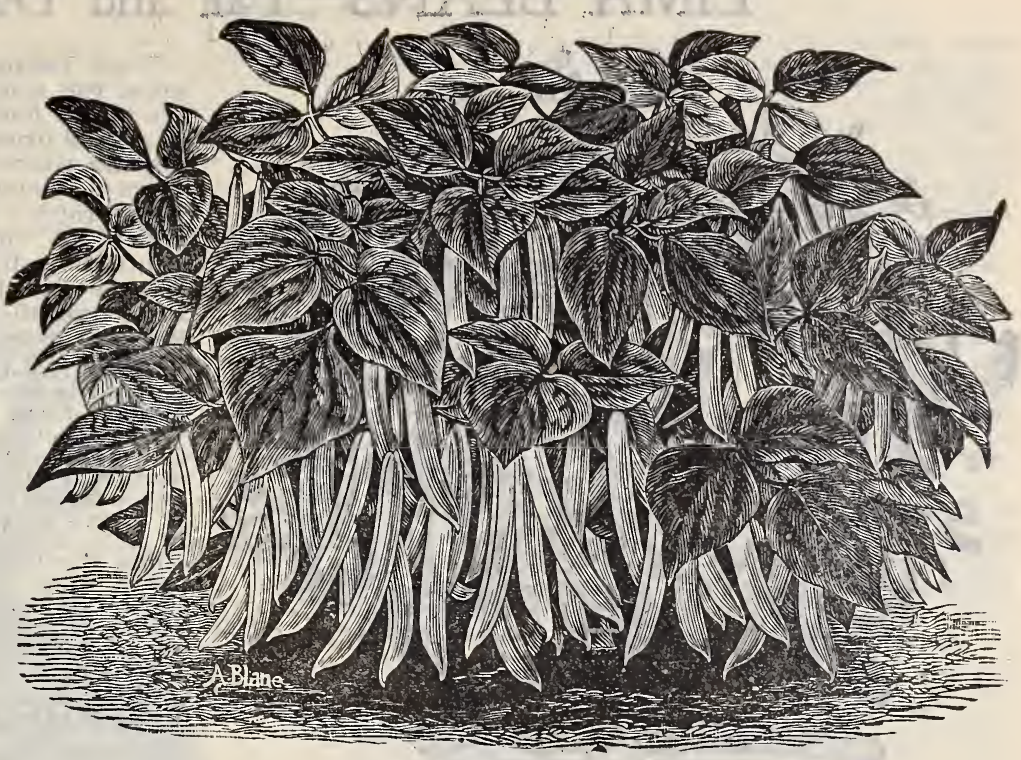

Currie's Rust-Proof Wax.

right, holding the pods well off the ground. The pods are long, flat and tender, of a beautiful golden color, and of the finest quality. One of the most popular kitıds with truckers for shipping. Pkt. 5c.; gt. $25 \mathrm{c}$.; peck, $\$ 1.50$; bu. $\$ 5.50$.

DAVIS KIDNEY WAX. A first early wax snap bean; nearly always rust-proof, and extraordinarily productive. It holds its pods well up off the ground; always matures plump, full and solid, and of a beautiful yellow appearance. Pkt. 5 c.; qt. 25 c.; peck, $\$ 1.50 ;$ bu. $\$ 5.50$.

WARDWELL'S KIDNEY WAX. One of the most popular and productive wax sorts. The pods are long, thick, and tender. A great favorite for shipping, the home market and family garden. Pkt. $5 \mathrm{c}$.; qt. 25 c. ; peck, $\$ 1.65$; bu. $\$ 6.25$.

GOLDEN EYEWAX. A most reliable cropper, standing adverse weather better than any other kind. The vines grow bushy and strong, holding the pods well off the ground. The pods are thich, of a waxy yellow color, uniform in size, free from rust and blight, and keep well after picking. Pkt. 5c.; qt. 25 c.; peck, $\$ 1.40$; bu. $\$ 5.00$.

BLACK WAX. A favorite main crop wax variety. Pods are round, waxy yellow, solid and tender. Pkt. 5c.; qt. 25c.; peck, $\$ 1.50$; bu. $\$ 5.50$.

DWARF GOLDEN WAX. The standard wax variety. Pods long, semiround, golden yellow, very fleshy and wax-like. It is of the highest quality as a snap. Pkt. 5c.; qt. 25c.; peck, $\$ 1.60$; bu. $\$ 6.00$.

\section{POLE OR CORN-FIEID SNAP BEANS.}

Culture-Pole beans are more sensitive to cold and wet than the bush beans, and should not be planted before May. Set poles eight feet long firmly in the ground, four feet apart each way, and put five or six beans, eye downward, in each hill. It requires about one pint to plant one hun-
dred hills, one to two pecks to plant an acre. They are also largely planted in corn.

OLD HOMESTEAD, or IMPROVED KENTUCKY WONDER. This is the earliest of all the green podded pole beans. Enormously productive, bearing its pods in clusters. The pods are long, crisp, tender, and bright green in color. A very prolific variety, and one of the best in our list. Pkt. 10c.; qt. $30 \mathrm{c}$.; peck, $\$ 1.85$.

SOUTHERN PROLIFIC. Very productive; makes excellent green cut-short snaps. Pkt. 5c.; qt. 25 c.; peck, $\$ 1.50$.

CUTSHORT or CORNFIELD. Has red speckled beans; snaps resemble the Bush Valentine in appearance. Pkt. 5c.; qt. 25c.; peck, $\$ 1.50$.

FAT HORSE or CREASEBACK. One of the earliest pole snaps, exceedingly productive; pods in clusters. Pkt. 5c.; qt. 25c.; peck, $\$ 1.60$.

OCTOBER or HORTICULTURAL (Speckled Wren's Egg). This is used both for snaps and as shell beans, and is the variety so largely used through New England for the famous "Boston Baked Beans." Pkt. 5c.; qt. 25c.; peck, $\$ 1.60$.

SCARLET RUNNERS. An ornamental variety, producing bright scarlet flowers. The shell beans make an excellent dish. Pkt. 10c.; qt. 30c. 


\section{LIMA BEANS-Tall and Dwarf.}

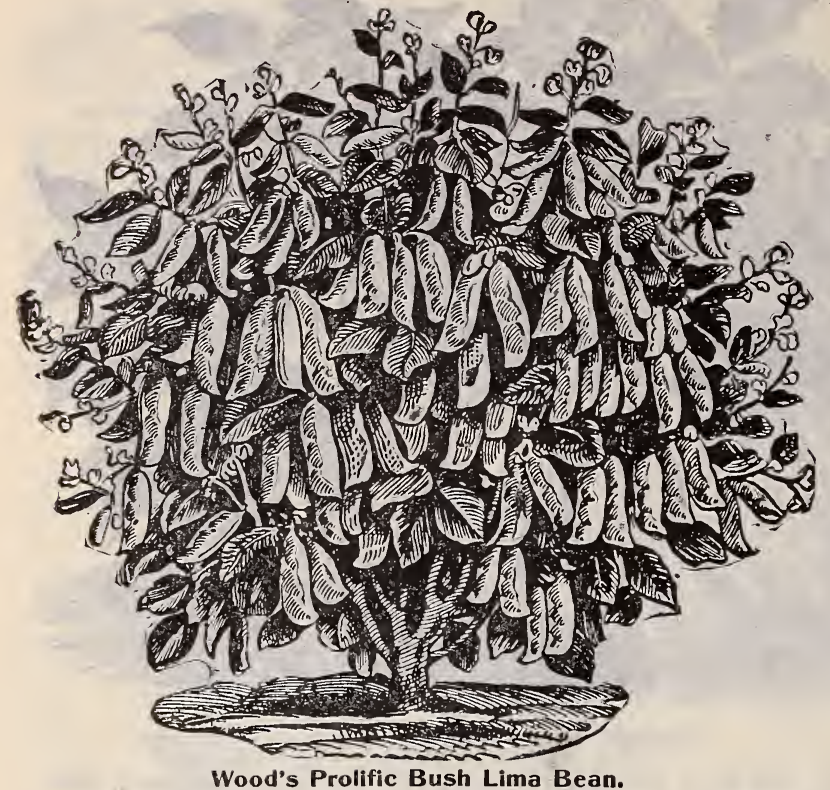

Lima Beans are not only profitable to grow for sale as green shell beans, but are also a most satisfactory crop to grow to sell as dried beans on our market during the winter. The dried beans are always in demand, and usually bring very good prices. They are a crop that can be grown to the best advantage in the South, both by farmers and truckers. The Wood's Prolific Bush, Wood's Improved Pole, and the Small Lima, are the best kinds to grow for this purpose.

Culture-Lima beans should not be planted before the weather gets warm, in May, Of the large seeded sorts, such as Ford's, Burpee's, and Large Lima. one quart will plant one huridred hills; of the smaller sorts, one quart will plant about two hundred hills. Poles eight or ten feet in length should be firmly set in the centre of hills before the seed is planted. Bush Lima should be planted in rows three feet apart, dropping two or three beans fifteen apart, dropping two or three beans fifteen inches apart in the rows. Cover about one one and a half to two pecks to plant an acre.

DWARF, OR BUSH LIMAS. WOOD'S PROLIFIC BUSH LIMA. This splendid new variety is rapidly superseding the old varieties of Bush Limas wherever it is grown. The most valu-

able improvement that has been introduced in Bush Lima Beans since the first introduction of the same, far surpassing the ordinary Bush Lima in size of beans, earliness and prolific yielding qualities. This bean makes a larger growth than the ordinary Bush Lima, such a growth at first that it frequently appears as though it would put out runners. It will be found, however, of the true bush form, its stems being practically loaded down with beans. In our opinion, it will easily yield twice as much as the old form of Bush Lima. Pkt. 10c.; qt. 30c.; pk. $\$ 1.90 ;$ bu. $\$ 7$.

BURPEE'S BUSH LIMA. This is the bush form of the well-known Large Lima, and although not so early or productive as the preceding variety, the large size of the beans makes it desirable. Pkt. 10c.; qt. 30c.; peck, $\$ 1.85$,

\section{POLE LIMAS.}

WOOD'S IMPROVED POLE LIMA. A variety of superior merit, distinct from other Lima Beans. It is larger than the Small Lima or Butter Bean, earlier, yields more, and is better in flavor. The best sort for market or family use. See "Seeds of Special Merit," page 4, for full description. Pkt. 10c.; qit. 30c.; peck, $\$ 2.00$.

SMALL LIMA or BUTTER BEAN. Earlier and more productive than the Large Lima. Pkt. 5c.; qt. 25c.; peck, $\$ 1.65$.

FORD'S MAMMOTH PODDED LIMA. This is, without exception, the largest podded and most productive of all Large Limas. It is the result of twenty years' selection by a successful market gardener, and far surpasses in size and productiveness any other variety. The pods usually contain five to seven beans of most excellent quality. The vines grow vigorously, setting the beans early at the bottom of the pole, and continuing bearing until frost. Pkt. 10c.; qt. 30c.; peck, $\$ 2.00$.

LARGE WHITE LIMA. The old, well-known sort, making large sized beans of superior flavor. Pkt. 5c.; qt. 25 c.; peck, $\$ 1.60$.

\section{BRUSSELS SPROUTS.}

Produces along the whole length of the stem a number of small sprouts, resembling miniature cabbages one or two inches in diameter; excellent flavor, and should be much more largely grown, as it is much more desirable as a table dish than cabbage. In the fall, break down the larger leaves, so that the little cabbages will have more room to grow. Sow in May or June, and cultivate precisely like late cabbage, except that they can be planted closer together. One ounce of seed will produce about 1,500 plants.

PERFECTION. The best variety; is closely covered with large, compact sprouts. Pkt. 5c.; oz. 15c.; 1/4 lb. 45c.; lb. $\$ 1.35$.

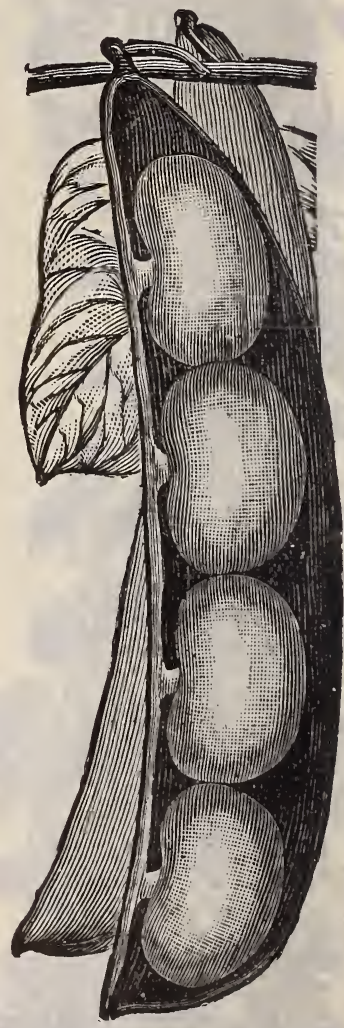

Wood's Improved Pole Lima Bean. 


\section{BEETS.}

Culture.-F'or earliest use, sow beets in hot-beds and transplant, cutting off the outer leaves when setting out. For the early out-door crop the sowing should be made as soon as the ground can be worked, while the main sowing should be made in March, or the beginning of April. Beets thrive best in light, loose, fresh, clean, deeply worked soil, that has been well manured for the previous crop. Winter Beets and Mangels should be sown in April or May, and can be put in as late as June, although at this late date there is some risk, and the seed should be carefully soaked before sowing. For field culture, the seed should be sown in drills two to two and a half feet apart, and covered to a depth of about one inch. Thin out the plants to four inches apart. One ounce of seed will sow fifty feet of drill; six to eight pounds required for one acre. For a small garden, the drills need not be more than fifteen inches apart. Garden required for one acre. For a small garden, the drils need not be more than fifteen inches apart

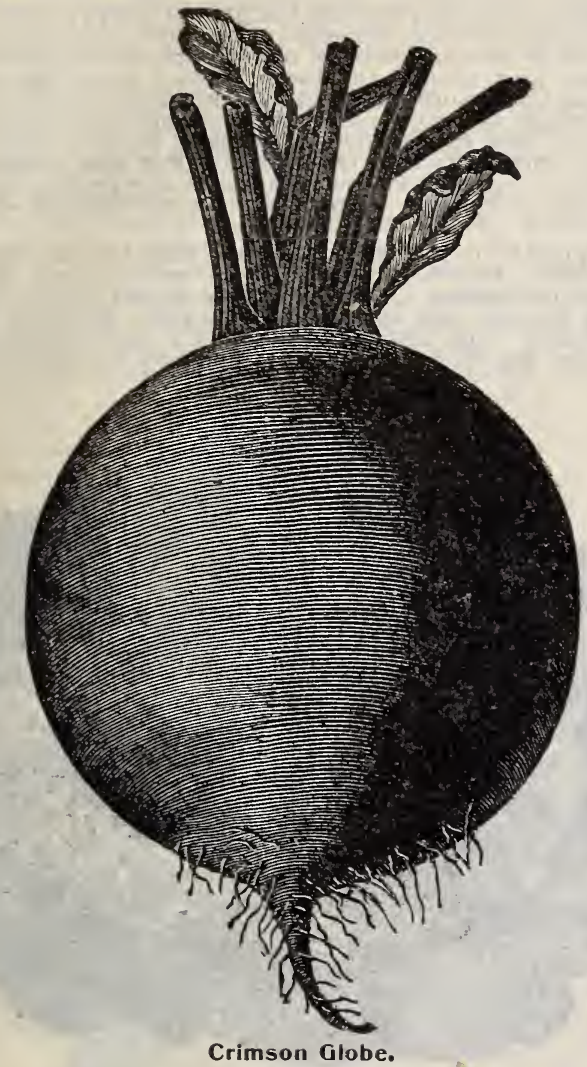

WOOD'S CRIMSON GLOBE. This splendid new variety has proven to be the most valuable introduction in beets in recent years. The color is most distinct, being of a rich, deep crimson; in shape uniformly a perfect globe; the skin is smooth and clean. It is extra early in maturity, and is proving specially desirable and profitable for market gardeners and truckers. Its attractive appearance, splendid flavor and other fine table qualities will make it a general favorite wherever grown. Pkt. 5c.; cz. 10c.; 1/4 Ib. 25c.; lb. $75 \mathrm{c}$.

CROSBY'S EGYPTIAN. This produces a larger and more globular shaped root, and is smoother and of better quality than the original Egyptian Beet, from which it is a selection and improvement. It is extremely early, and takes on its color and shape quicker than other kinds, and is admirably adapted for forcing, as well as outdoor growing. Very popular with truckers and market gardeners everywhere. Pkt. 5c.; oz. 8c.; $1 / 4$ lb. 15c.; lb. 45c.; $10 \mathrm{lb}$. lots and over, $40 \mathrm{c}$. lb.

DETROIT DARK RED. A blood red, early, turnip-shaped variety. Has small upright tops; fine round shape. Skin and flesh dark blood red. Very tender and sweet. Remarkably uniform in growth, and a parficularly desirable sort for truckers and market gardeners. Pkt. 5c.; oz. 8c.; 1/4 lb. 15c.; lb. 45c.

EXTRA EARLY BASSANO, or SUGAR. Very early, sweet and tender; light color. Pkt. $5 \mathrm{c}_{\text {. }}$ : oz. 8c.; $1 / 1$ lb. $15 \mathrm{c}$.; lb. $35 \mathrm{c}$.

EXTRA EARLY ECLIPSE. Very early, handsome, smooth, dark, round-shaped beet. Small top, and of excellent table qualities. Makes an attractive seller in market. Pkt. 5c.; oz. 8c.; $1 / 4$ lb. $15 \mathrm{c}$; lb. $45 \mathrm{c}$.

DIRIGO. A new variety, valuable on account of its earliness. It has a small top, slender stems and smooth skin. The color of the flesh is uniformly dark crimson, with beautifully-marked rings. The flesh is crisp and sweet. It is flattish round in shape. Pkt. $5 \mathrm{c}$.; oz. $8 \mathrm{c}$.; $1 / 4 \mathrm{lb}$. 15c.: Ib. $45 \mathrm{c}$

EGYPTIAN. An old standard sort, both for the market gardener and family. Produces fine, smooth, deep red roots. About ten days earlier than the Blood Turnip. Pkt. 5c.; oz. 8c.; $1 / 4 \mathrm{lb}$. $15 \mathrm{c}$; $1 \mathrm{~b} .35 \mathrm{c}$.

EXCELSIOR or COLUMBIA. On account of its earliness and attractive shape and color, this sort is of special interest to market gardeners. The flesh is blood red, rich and tender. The tops are small, permitting close cultivation. Pkt. 5c.; oz. 8c.; 1//4 lb. $15 \mathrm{c}$.; 1b. $45 \mathrm{c}$.

BASTIAN'S EARLY BLOOD TURNIP. Of quick and large growth, bright red color, not quite so deep a red as Blood Turnip. Pkt. 5c.; Oz. 8c.; $1 / 1$ lb. $15 c$. ; 1 b. $35 c$

EDMAND'S EARLY BLOOD TURNIP. Of beautiful round form and good size; flesh dark red and finest quality. Pkt. 5c.; oz. 8c.; 1/4 lb. 15c.; Ib. $40 \mathrm{c}$

IMPROVED EARLY BLOOD TURNIP. Of a dark red color, smooth, uniform size, and of excellent table qualities. One of the best for main crop planting, as it keeps in condition longer than the other kinds. Pkt. 5c.; oz. 8c.; $1 / 4$ 1b. $15 \mathrm{c}$. lb. $35 \mathrm{c}$.

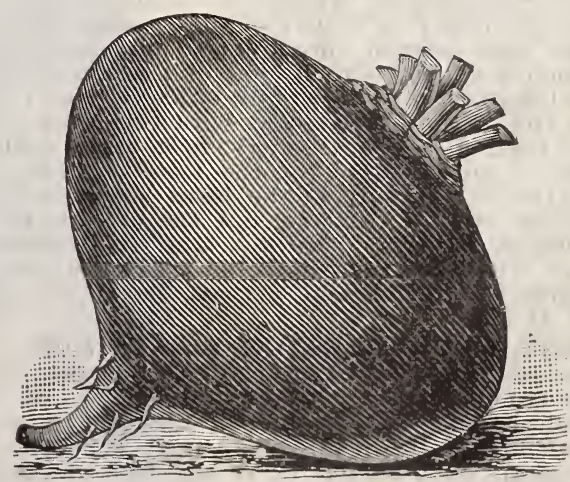

Crosby's Egyptian.

LONG SMOOTH BLOOD. An excellent darkfleshed main crop sort. Very tender and sweet, and remaining so when kept until spring. Pkt. 5c.; oz. 8c.; 1/4 lb. 15c.; lb. $30 \mathrm{c}$.

MANGELS, STOCK, or SUGAR BEETS. For prices, full descriptions, and information, see page 23. 


\section{WOOD'S CABBAGE SEEDS.}

The largest truckers in the South pronounce Wood's Cabbage Seed unequalled in profitable crop results, and our sales of Cabbage Seed, which have always been very large, are increasing rapidly every year. This is the best of evidence as to the profitable crop results from the use of Wood's Cabbage Seed, and as to its superiority for use in the South.

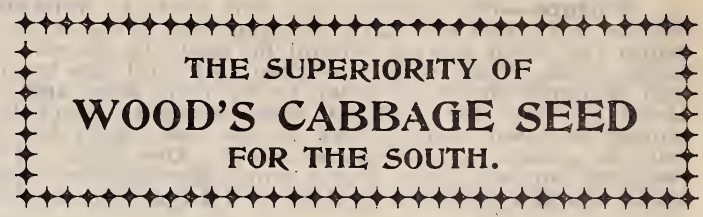

Culture.-Cabbage do well on any rich, thoroughly cultivated soil, provided the plant food is abundant and water in sufficient amount to make it available. For setting out in November,. sow early sort in open ground in September; or for setting out in the spring, sow in gentle hot-beds, or cold frames in January or February, giving plenty of air to harden, or sow in the open ground in March. When large enough, transplant to rows two and a half to three feet apart, setting the plants eighteen inches apart in the rows. Work frequently and deeply. Fall seeding should not be made before the 20 th of September, as the cabork is liable to to seed in the spring if sown too early in the fall. Sudden changes in the weather bage is liable to go to seed in the spring if sown too early in the fall. Sudden changes in the weather
from mild to cold often cause cabbage to go to seed in the spring and early summer. For late cabbage, sow in April, May or June, and transplant in July or August to rows three feet apart and two feet between the plants. One ounce of cabbage seed will produce about two thousand plants; six ounces will produce enough plants to set out one acre.

Insect Remedies.-For the flea beetle, which eats the plants in the seed bed, the remedies are Slug Shot or Tobacco Dust, applied while the dew is on the ground. For the green cabbage worm, apply Slug Shot. Paris Green mixed with land plaster or flour is also efficacious. This should be mixed at the rate of one ounce of Paris Green to six pounds of flour or land plaster, and applied after a rain, or when the dew is on the plants. For the terrapin or spotted cabbage bug, hand-picking is the only remedy. Mustard plants growing in the cabbage rows will draw the bug from the cabbage, and the mustard plants can be pullea up and burned, and the bugs destroyed in this way.

ALPHA. A new and improved extra early flat headed cabbage, introduced by one of the most famous cabbage growers on Long Island. Its general character is that of the Flat Dutch, but it is much earlier, and specially remarkable for its solidity and freedom from superfluous or waste leaves. The strong points of value in this cabbage are: its earliness, remarkable solidity and compactness of growth, enabling it to be planted closer than other varieties, and also its attractive form and shape. It is very strongly recommended by those who have grown it, as an extra early variety. Pkt. 5c.; oz. 25 c.; $1 / 4$ lb. 75 c.; lb. $\$ 2.50$.

WOOD'S EXTRA EARLY. This is the earliest cabbage in our list, making large pointed heads, larger than the Wakefield, but not quite so solid. A rapid grower, and recommended to all desiring a first.class extra early cabbage. Pkt. 5c.; oz. 20c.; 1/4 lb. 60c.; lb. \$2.00.

WOOD'S SELECTED EARLY JERSEY WAKE. FIELD. Our stock of this is very superior, and it has attained a big reputation with truckers and market gardeners wherever grown. One of our largest truckers in this section, who planted different lots of Wakefield Cabbage seed, obtained from four or five of the leading seedsmen the past season, pronounced our stock very much superior, both in size and productiveness, and stated that it paid him twice as much profit as any of the other stocks which he grew. It is an ideal market gardeners' first early cabbage, and is suited alike for the family garden and market. Not only is the head large and solid for so early a cabbage, but the outside foliage permits of close planting, and its uniformity and reliability for producing a crop makes it a general favorite. Pkt. 5c.; oz. 20c.; 1/4 lb. 50c.; lb. $\$ 1.75$.

LARGE, or CHARLESTON WAKEFIELD. This is a few days later than the Early Jersey Wakefield, but makes a larger and firmer head. In fact in our trial grounds it makes the largest and most solid heading of early cabbages. We strongly recommend it as the best main crop early cabbage grown, for the home garden and market. Our seed of this is grown from a specially selected stock, and is unequalled in crop results. Pkt. 5c.; oz. 20c.; $1 / 4$ lb. 50c.; 1b. $\$ 1.85$.

EARLY FLAT DUTCH. One of the most popular and reliable of the medium early varieties. Makes large flattish-shaped, solid heads. Pkt. 5c.; oz. 15c.; 1/4 lb. 40c.; 1b. \$1.40.

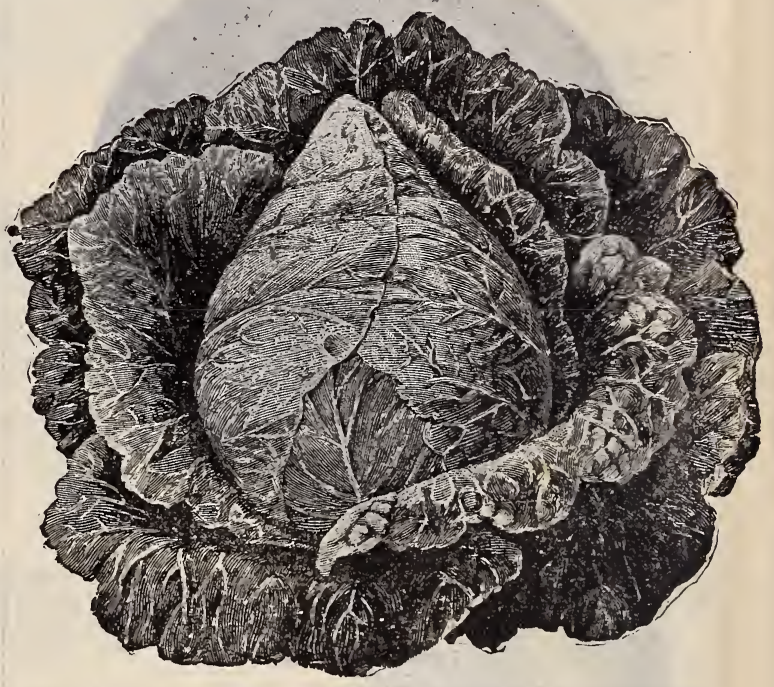

Charleston Wakefield.

WINNINGSTADT. Medium early; makes very firm, conical-shaped, hard heads. Pkt. 5c.; oz. $15 \mathrm{c} . ; 1 / 4$ lb. $40 \mathrm{c} . ;$ lb. $\$ 1.25$.

EARLY YORK. A favorite with many; early and very tender. Pkt. 5c.; oz. 15c.; 1/4 lb. 35c.; lb. $\$ 1.20$.

LARGE YORK. Larger and about two weeks later than Early York. Makes excellent flavored cabbages, but not very solid. Pkt. $5 \mathrm{c}$.; oz. $15 \mathrm{c}$.; $1 / 1$ lb. $35 \mathrm{c}$.; lb. $\$ 1.20$.

HENDERSON'S EARLY SUMMER. A splendid sort for market gardeners, coming in just after the Wakefield. Makes large, fine round heads, which stand the heat well. Plkt. 5c.; oz. 20c.; $1 / 4$ lb. 50c.; lb. $\$ 1.50$.

EARLY DRUMHEAD. A medium early round head cabbage, makes good, solid heads. Pkt. 5c.; oz. 15c.; $1 / 4$ lb. 40 c.; lb. $\$ 1.40$.

ALL-HEAD EARLY. A compact growing, hardheading flat variety, recommended principally for summer and early fall crop, but when sown. late also makes excellent solid and good keeping winter cabbages. Pkt. 5c.; oz. 20c.; 1/4 lb. 60 c.; lb. $\$ 1.90$. 
SOLID SOUTH. A magnificent cabbage, resem. bling the Early, Summer, but is earlier, larger, more uniform, has fewer outside leaves, and is less liable to run to seed when sown in the fall All of our customers who grow this variety are enthusiastic in its praise. Does well both for early and late crop, and is equally well adapted for the family garden and for shipping. A most valuable southern variety. Pkt. 5c.; oz. 20c.; $1 / 4$ lb. 60 c.; lb. $\$ 2.00$.

SUREHEAD. For a sure header this has proved one of the best of main crop cabbages. Grows very large and solid, and will be found a fine sort for late crop. Pkt. 5c.; oz. $20 \mathrm{c}$; $1 / 4 \mathrm{lb}$. $50 \mathrm{c}$; lb. $\$ 1.60$.

HENDERSON'S SUCCESSION. A good second early cabbage, making large, flat heads, very similar to All Seasons. Pkt. 5c.; oz. 20c.; 1/4 1b. 50c.; lb. $\$ 1.75$.

ALL SEASONS. As the name indicates, this is an "all seasons" variety, being equally good for fall and winter as for summer use. It is ready for cutting nearly as early as Early Summer and is much larger in size. The heads are large and solid, round, flattened on top, and of best quality Pkt. 5c.; oz, 20c.; 1/4 lb. 50c.; lb. $\$ 1.60$

DANISH BALLHEAD or HOLLANDER CABBAGE. A distinct type of winter cabbage, maturing later than the Flat Dutch. Especially recommended for its great solidity and excellent keeping qualities. The heads are nearly round in form, very hard and solid, and weigh heavier for their size than any other cabbage. While this variety has not been very generally grown throughout the South, we recommend our customers to give it a trial, believing that it will prove to be a most valuable winter and shipping variety. Pkt. $10 \mathrm{c}$ : oz. $30 \mathrm{c}$; $1 / 4$ lb. $80 \mathrm{c}$; $1 \mathrm{lb}$. $\$ 2.50$

BUNCOMBE or NORTH CAROLINA. A variety in great favor in Western North Carolina. Makes large, firm heads, very hardy and a good keeper. Specially recommended as a winter cabbage. Pkt. 5c.; oz. 20c.; $1 / 4$ lb. 50 c.; lb. $\$ 1.60$.

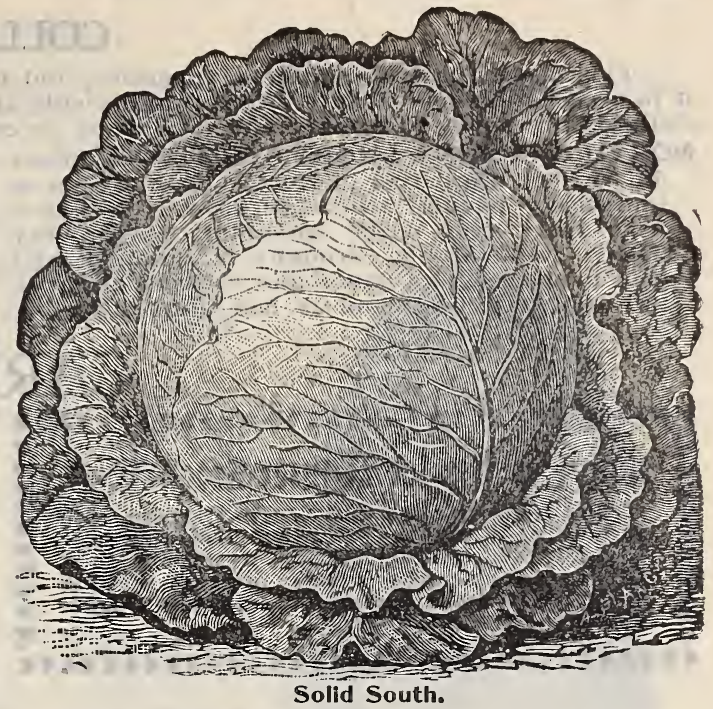

LARGE LATE FLAT DUTCH. An old, ponular variety, making large, solid, flat-shaped heads; one of the best winter cabbages. Pkt. 5c.; oz. 15c.; $1 / 4$ lb. $40 \mathrm{c}$; ; lb. $\$ 1.25$

LARGE LATE DRUMHEAD. This resembles the Flat Dutch, but is rounder in shape. The heads are large and solid; an excellent keeper. Pkt. 5c.; oz. 15c.; 1/4 lb. 40c.; lb. $\$ 1.25$.

WOÖD'S PRIZE HEAD LATE FLAT DUTCH. This is a most superior strain of Late Flat Dutch Cabbage, and one that has given the very best crop results and satisfaction all through the South, our customers who grow it pronouncing it the largest yielding and surest cropping of late fall and winter cabbages. It is specially

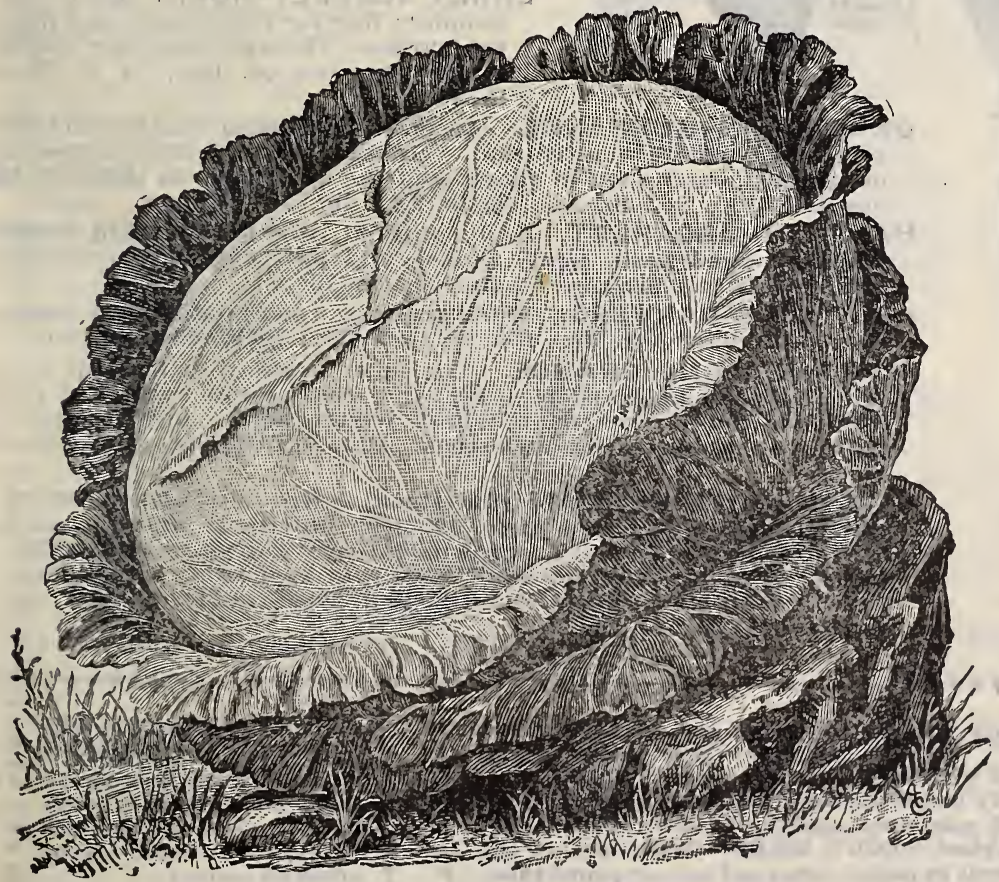

Wood's Prize Head Late Flat Dutch.

CABBAGE PLANTS. For prices, etc., see "Vegetable Plants," page 3. suited to the South, and we strongly recommend all who grow cabbage for late fall and winter to use our Wood's Prize Head Late Flat Dutch. Pkt. 5c.; oz. $20 \mathrm{c}$; $1 / 4$ lb. $50 \mathrm{c}$; $1 \mathrm{~b}$. $\$ 1.50$

AMERICAN PERFECTION DRUMHEAD SA VOY. The Savoy cabbages are very tender and of fine flavor, very much superior in this respect to the ordinary late fall and winter cabbage. Should be much more largely grown, both for home use and market. The strain of American Drumhead Savoy which we offer makes large sized heads of most superior quality, and truckers and private gardeners alike will find it an excellent variety. Pkt. 5c.; oz. 20c.; $1 / 4$ lb. 50 c.; lb. $\$ 1.60$.

GREEN GLAZED. A vigorous growing, worm-resisting variety, succeeding well in sections where it has been found difficult to grow other varieties on account of insect attacks. Pkt. 5c.; oz. 15c.; $1 / 4$ lb. $45 \mathrm{c}$; ; lb. $\$ 1.40$

RED DUTCH. Used principally for pickling. Pkt. $5 \mathrm{c}$. oz. $20 \mathrm{c}$; $1 / 4$ lb. $50 \mathrm{c}$; $1 \mathrm{~b}$. $\$ 1.50$. 


\section{COLLARDS.}

This is peculiarly a Southern vegetable, and is highly prized by the people of this section, where it is used as greens. A sure cropper, and yields abundantly. Collards also make excellent stock feed. Collards are sown both early and late, same as cabbage.

NORTH CAROLINA SHORT STEM. This splendid variety originated in North Carolina, and is immensely popular wherever grown. It has a very short stem, large spreading leaves, very hardy, withstanding drought in summer and cold in winter. Its flavor and cooking qualities are the very best, and it has unquestionably

proved itself far superior to any other collard in cultivation. Pkt. 5c.; oz. 15c.; 1/4 lb. 35c.; lb. $\$ 1.00$.

TRUE GEORGIA. The old standard sort, which has been in use in the South for years. Pkt. $5 \mathrm{c}$.; oz. $10 \mathrm{c}$; $1 / 4$ lb. $20 \mathrm{c}$; lb. $65 \mathrm{c}$.

\section{CARROT.}

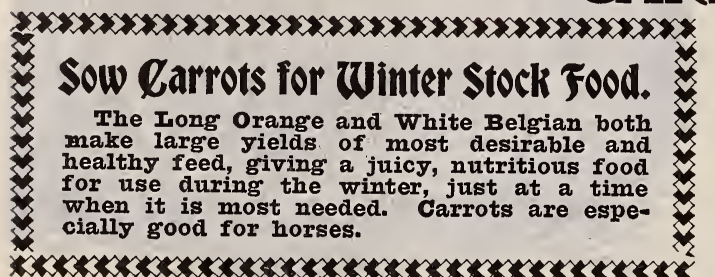

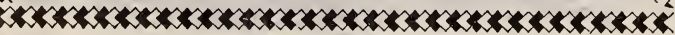

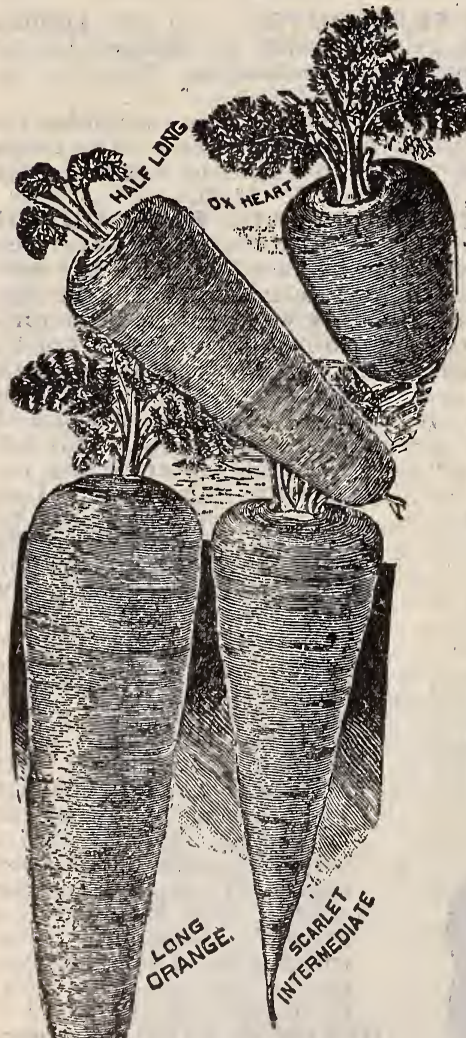
lb. $65 \mathrm{c}$.

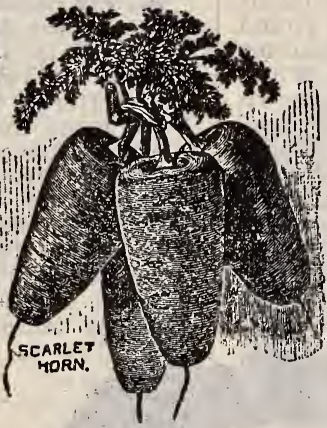

worked soil in drills twelve inches apart and half an inch deep, and afterwards thin out to three to six inches apart. Fertilize liberally with well-rotted stable manure and a rapidly available potash fertilizer. The early varieties should be sown as early in. the spring as the ground can be worked, and the later sorts from middle of March until June. In dry weather soak the seed before sowing. To keep for winter use for the table, horses or cattle, pack the roots in moderately dry earth or sand in the cellar; or they can be pitted out of doors and covered with a few inches of straw and six or eight inches of earth to keep out the frost. One ounce of seed will sow one hundred feet of drill; three or four pounds to one acre.

Insect Remedy.-If the parsley or carrot worm attacks the foliage, use Slug Shot, applying while the dew is on.

WOOD'S SCARLET INTERMEDIATE. A fine, handsome carrot, in form midway between the Long Orange and Early Scarlet Horn. The roots are large, uniform, and symmetrical, with scarcely any core. Splendid either for garden or field culture, and very popular, both for market and family use. Pkt. 5c.; oz. 10c.; $1 / 1 / 1$ lb. 25c.; lb. $85 \mathrm{c}$.

EARLY SCARLET HORN. Eariy and popular; fine for the private and market garden. Grows about four inches long. Pkt. 5c.; oz. 10c.; $1 / 4$ lb. 25c.; lb. $75 \mathrm{c}$.

OXHEART, or GUERANDE. An entirely distinct variety and deserving of general cultivation. Grows three to four inches in diameter, nearly oval in shape, and the quality is all that can be desired. Pkt. 5c.; oz. 10c.; 1/4 lb. $25 \mathrm{c}$.; 1b. $80 \mathrm{c}$.

HALF LONG SCARLET. Early, without core, smooth skin, bright orange colored flesh, easily pulled, and well adapted to shallow soils. Pkt. 5c.; oz. $10 \mathrm{c}$.; $1 / 4$ lb. $25 \mathrm{c}$; ; lb. $75 \mathrm{c}$.

HALF LONG DANVERS. Thick growing, good quality, and makes very satisfactory yields. Pkt. $5 \mathrm{c} . ;$ oz. $10 \mathrm{c} . ; 1 / 4 \mathrm{lb} .25 \mathrm{c}$; $1 \mathrm{lb} .75 \mathrm{c}$.

IMPROVED LONG ORANGE. The most popular main crop sort. The roots are long and tapering, of a deep orange color, and free from side roots. One of the best winter sorts, and is largely grown for table, market and stock. Pkt. 5c.; 0z. 10c.; 1/4 1b. 20c.;

LARGE WHITE BELGIAN (for stock). Grows to an enormous size, making very large yield of most nutritious and fattening feed for stock. Should be grown by every dairyman and cattleraiser. It helps in giving that variety in feed which is so desirable to keep cattle healthy and in first-class condition. Pkt. 5c.; oz. $8 \mathrm{c} . ; 1 / 4$. 1b. $15 \mathrm{c}$; 1b. $40 \mathrm{c}$.
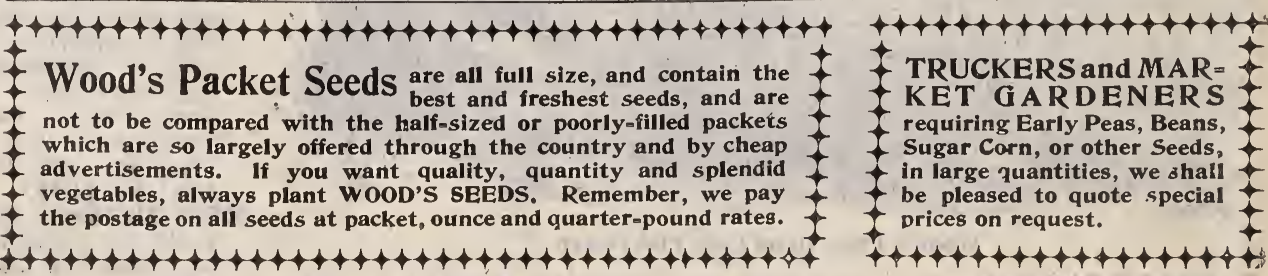


\section{CUCUMBER.}

The crop of Cucumber seed was cut short very seriously the past season by unfavorable weather conditions, which makes price much higher than usual this year.

Culture.-For very early crop, plant in hot-bed, in pots or small paper boxes, or on pieces of sod, grass side dowll, so that they can be readily transplanted; or plant in the open ground as soon as the weather readily transplanted; or plant in the open ground as soon as the weather about four feet apart each way. The hills should be previously prepared by mixing a shovelful of well-rotted manure with the soil. Put about ten seeds in each hill, and when all danger of insects is past, thin out to four plants. The fruit should be gathered when large enough, whether wanted or not, for if left to ripen on the vine, it destroys its productiveness. For late pickling, plant in June or July. One ounce will plant fifty hills; two pounds will plant one acre.

ZWAIM. For full description of new and desirable pickling cucumber, see "Seeds of Special Merit," p. 4. Pkt. 10c.; oz. 30c.; 1/4 lb. 90c.

CUMBERLAND. A most superior new pickling cucumber; crop very short; can only offer in packets and ounces. Pkt. 10c.; oz. 25c.

NEW MODEL. A superior early variety of the White Spine type, but is earlier, and a darker color. Pkt. 10c.; oz. 20c.; 1/4 lb. 60c.; lb. $\$ 2.00$.

EMERALD. The rich, dark-green color for which the growers have sought so long is obtained in the Emerald, after several years of careful and scientific work. It is strictly an evergreen, retaining its color until fully ripe. It sets its fruit early, producing long, straight, handsome cucumbers, the flesh of which is particularly crisp, tender, and of the most delicate flavor. Highly recommended for slicing, the young. fruits for sour pickle, and the riper ones for sweet pickle. Pkt. 5c.; oz. 15c.; 1/4 1b. 50c.; 1b. \$1.75.

SIBERIAN. Extra early; very prolific; makes good-sized cucumbers of a desirable market shape. Pkt. $5 \mathrm{c}$.; oz. $15 \mathrm{c}$.; 1/1 lb. $45 \mathrm{c}$.; lb. $\$ 1.40$.

THORBURN'S EVERBEARING. Small sized, very early, and enormously productive. Continues long in bearing. Pkt. $5 \mathrm{c}$.; oz. 15c.; $1 / 1$ lb. $45 \mathrm{c}$; ; lb. $\$ 1.35$.

IMPROVED EARLY WHITE SPINE. In the large trucking districts this sort is grown more largely for shipping than all others. The cucumbers grow to medium size, very prolific, and are excellent for table use and for pickling. Pkt. 5c.; oz. 15c.; $1 / 4$ lb. $50 \mathrm{c}$.; lb. $\$ 1.75$.

IMPROVED LONG GREEN. The cucumber for all purposes, being highly prized for table, market, and pickling. Of a dark green color, firm and crisp. The young fruits are best for sour pickle, the riper ones for sweet pickle. Pkt. 5c.; oz. 15c.; $1 / 1$ lb. 50c.; lb. $\$ 1.75$.

GREEN PROLIFIC PICKLING. One of the best for pickling; dark green, very productive, and of the uniform small size; preferred by pickle factories. Pkt. 5c.; oz. $20 \mathrm{c}$.; $1 / 4 \mathrm{lb}$. 50c.; lb. $\$ 1.75$.

WESTERFIELD'S CHICAGO PICKLING. A very prolific and valuable pickling cucumber. Pkt. 5c.; oz. $15 \mathrm{c}$.; $1 / 4$ lb. $45 \mathrm{c}$; $1 \mathrm{~b} . \$ 1.40$.

GHERKIN, or BURR. A small prickly variety, used exclusively for pickles. Pkt. 5c.; oz. 20c.; $1 / 4$ lb. 50c.; lb. $\$ 1.60$.

JAPANESE CLIMBING. Distinct from other varieties, being a real climber, and can be grown on poles, trellis or porches. Vines extra strong; foliage more vigorous than other kinds. Very prolific of fruit, which is of dark green color, and of good table qualities. A valuable interesting novelty. Pkt. $10 \mathrm{c}$; oz. $40 \mathrm{c}$.

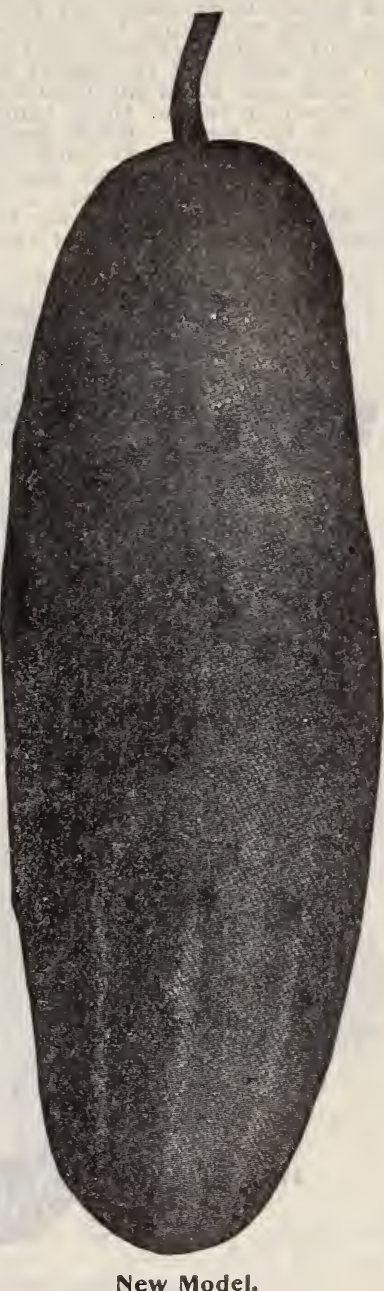

New Model.

\section{CRESS, OR PEPPER GRASS.}

Every farm has some place where water-cress can be sown to advantage, and once sown it reseeds and spreads very rapidly. Water-cress is a most delicious salad, and is becoming very popular in our markets, and a small piece started on the farm now will not only furnish a nice salad, garnishing, etc., for the table, but may prove quite a pin-money making crop in the future.

Culture.-Sow the Curled Cress at frequent intervals early in the spring in shallow drills twelve inches apart. Cress, like all salads, requires a rich soil. The Water Cress should be sown in the spring along the edge of brooks or small streams, or in wet, mucky land. Only one sowing is necessary, as it reseeds and increases very rapidly.

CURLED. Use as a small salad, like lettuce. The leaves impart a warm, pungent taste. Pkt. 5c.; oz. $10 \mathrm{c}$; $1 / 4$ lb. $15 \mathrm{c}$; 1b. $40 \mathrm{c}$.

WATER CRESS. One of the most delicious of small salads, and should be grown on every farm on which there is a small stream. Always in demand in the large city markets. Pkt. 10c.; oz. $35 \mathrm{c} . ; 1 / 4$ lb. $75 \mathrm{c}$.; $1 \mathrm{~b}$. $\$ 2.75$.

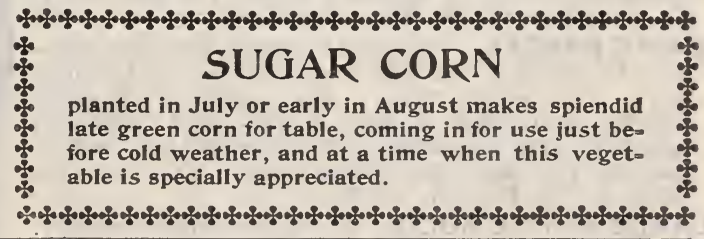

CADDO CO., S. C.-I have been planting cantaloupes for early market, and find your Extra Farly Hanover far superior to any of the varieties tested. Have bought seed from you the past two years, and can most heartily recommend them. 


\section{CELERY.}

Culture.-Sow in February, March or beginning of April in drills eight or ten inches apart, in a bed of fine rich soil, covering to a depth of one-foulth of an inch. If the soil is dry press the earth with the back of spade or roller after covering, and keep clear of weed or the young plants will be smothered out. Transplant from July to October. To prepare a bed for celery, throw out the earth to a depth of six inches and four or five feet wide, and put in three or four inches of well-rotted manure, dig in well, and cover with fine soil. Set the plants six to eight inches apart, in rows one foot apart, press the soil firmly to the roots, and when the plants are large enough earthing up can be commenced. The plants will need to be earthed up two or three times, and in doing this care should be taken not to let the earth get into the heart of the plant. When severe cold weather comes on, cover gradually with leaves, hay or straw, and place boards on top. In such a bed the stalks will blanch perfectly, and may be taken out during the winter for sale or use, as required. In field culture, when the celery is to be earthed up in the field for early use, the plants are set on the surface, in rows four feet apart and the plants set six inches apart in the row; or, if the plants are to be taken up and blanched in the cellar for winter use, they may be set in rows as close as two feet apart. Celery requires frequent cultivation, and the earth drawn up to the

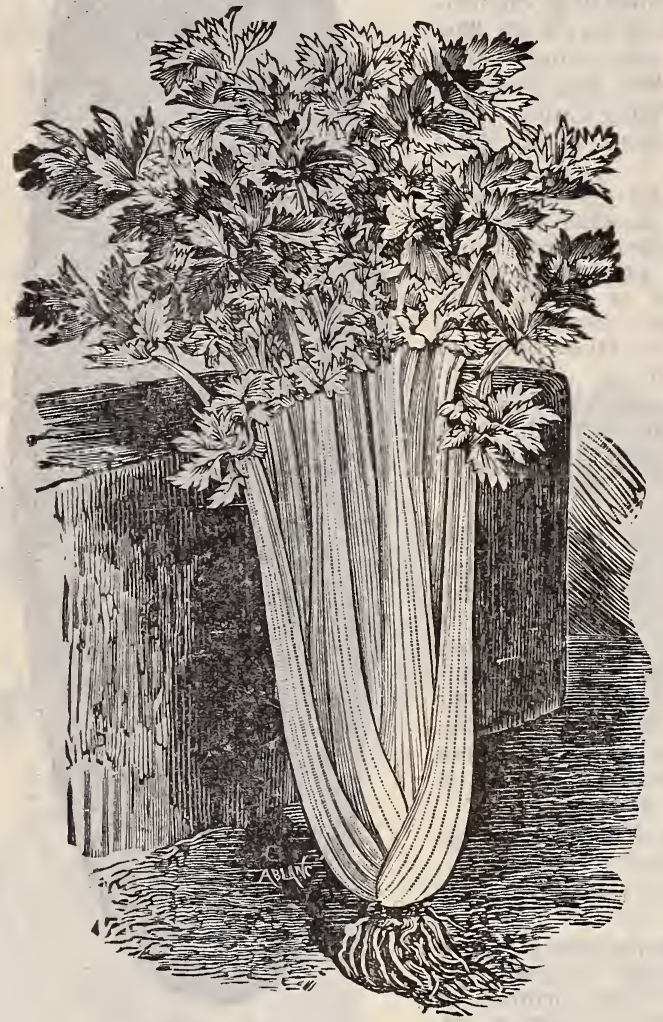

Golden Self-Blanching.

entirely white or light foliage, which requires little earthing up to blanch. It is handsome in appearance, and of good quality, but as it is not a very good keeper, should be planted only for early use. Pkt. 5c.; oz. $15 \mathrm{c}$.; $1 / \pm$ lb. 50 c.; lb. $\$ 1.50$.

PINK PLUME. Similar to the well-known White Plume, except that the stalks are tinged with pink. It is of very attractive appearance and good flavor. A strong grower, and requires but little blanching to make it ready for use. Pkt. 5 c.; oz. 20 c.; $1 / 4$ lb. 60 c.; lb. $\$ 2.00$.

GIANT PASCAL. One of the most popular celeries in our list. Easily blanched; a fine keeping sort, of excellent flavor. Has large, thick, solid stalks, beautiful golden heart, and blanches quickly. Of splendid keeping qualities, and is one of the best for winter use. Pkt. 5c.; oz. $15 \mathrm{c}$; $1 / 4$ lb. $40 \mathrm{c}$; lb. $\$ 1.25$.

LARGE WHITE SOLID. An old standard variety. Grow's to a large size; but does not make as large a growth of heart as some other sorts. Pkt. 5c.; Oz. 10c.; $1 / 4$ lb. 35c.; lb. $\$ 1.20$. plants as rapidly as it makes growth.

If it is desired to store the field-grown celery for winter use, the best way is to dig trenches in a welldrained spot in the open ground, one foot wide, and to a depth of a few inches less than the height of the,celery. The plants are then lifted and set close together, and the trenches filled in at the sides with earth. The edges of the trench should be made sloping from the tops of the plants. When severe cold weather comes on, cover gradually with leaves, hay or straw and place boards on top. In such a trench the stalks will blanch perfectly, and may be taken out any time during the winter, as desired. Celeriac, or Turnip-rooted Celery, needs no earthing up, and may be planted in rows 18 inches apart.

GOLDEN SELF-BLANCHING CELERY. Originator's stock. A vigorous growing and handsome variety, decidedly better in quality than the White Plume, and is larger in size. It is of compact growth, with a large, solid heart, and thick-ribbed stalks, which blanch easily. Is crisp and solid, free from stringiness, and of most delicious flavor. Color beautiful golden yellow, both stalks and leaves. Our strain of this variety is unsurpassed. Pkt. 10c.; oz. 40c.; $1 / 4$ lb. $\$ 1.00$; lb. $\$ 3.75$.

ROSE RIBBED SELF-BLANCHING (Golden Rose). This is of the same beautiful type of coldenching. It has the same beautiful, rich golden yellow color, but differs in the color of the outside ribs, which are tinged with a handsome rosy pink. Its earliness and self-blanching habit, and beautiful appearance unon the table, recommend it alike to the private and market gardener. Pkt. 10c.; oz. 40 c.; $1 / 4$ lb. $\$ 1.00 ; 1$ lb. $\$ 3.75$.

IMPROVED WHITE PLUME: This matures and can be used earlier than any other celery, being

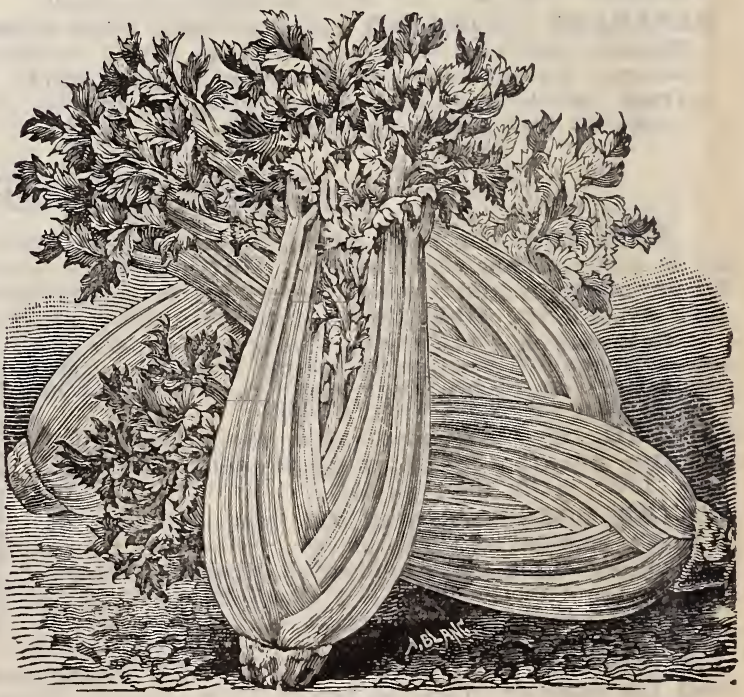

Giant Pascal. 
CELERY-Continued.

CRAWFORD'S HALF DWARF. White celeries are still in great favor with a good many of our growers, and this is one of the best and most satisfactory of the white sorts grown. Stalks crisp, and of fine nutty flavor. Of compact growth and fine keeping qualities. Pkt. 5c.; oz. $15 \mathrm{c} . ; 1 / 4$ lb. $40 \mathrm{c}$.; lb. $\$ 1.20$.

GOLDEN HEART, or GOLDEN DWARF. A standard sort of excellent flavor. Later than the self-bleaching varieties, but will keep better. Pkt. 5c.; oz. 15c.; 1/t lb. 40c.; lb. $\$ 1.20$.
PERFECTION HEARTWELL. A large growing solid sort, of excellent flavor. The heart is of golden yellow and very attractive appearance. Pkt. 5c.; oz. 20c.; 1/4 1b. 50c.; lb. $\$ 1.50$.

CELERIAC OP TURNIP-ROOTED CELERY. Grown exclusively for its roots, which,. when cooked, sliced and used with vinegar, makes a fine salad. Pkt. 5c.; oz. 15c.; 1/t lb. 40c.; lb. $\$ 1.25$.

SEASONING CELERY. Oz. 5c.; 1/1 lb. 10c.; 1b. $25 \mathrm{c}$.

CELERY PLANTS. See "Vegetable Plants." - 3

\section{CAULIFLOWER.}

Cauliflowers are being very successfully and profitably grown in Florida and in other trucking sections in the South, and we strongly recommend extensive trials by our customers everywhere.

Culture.-Sow in gentle hot-beds in January or February, and cultivate as for early cabbage. Work well, manure liberally, and give plenty of water; this is absolutely necessary. After they begin to head. fasten the leaves together over the top to protect from the sun and keep white. For late crop sow end of May or June, and transplant to a moist, rich soil, and cultivate as for winter cabbage. For fall planting sow in September, and transplant in November, same as early cabbage. They require plenty of manure, moisture and good culture. If these conditions are supplied, as fine cauliflowers can be grown in the South as anywhere in the United States, and they would be one of our best paying crops. One ounce of seed will produce about two thousand plants.

Insect Remedies.-The same insects attack cauliflower that attack cabbage. See under the head of cabbage for remedies. One ounce saltpetre dissolved in twelve quarts of water and sprinkled on the cauliflower or cabbage heads is also an excellent remedy for the green cabbage worm.

WOOD'S EARLIEST SNOWBALL. This is the best of all Cauliflowers for Southern growers. It is the earliest to head, and a remarkably sure header, making large, solid, peifect heads of pure white color and finest quality. Excellently adapted for forcing as well as for growing out of doors. Plt. 20c.; 1/t oz. 65c.; oz. $\$ 2.00 ; 1 / 4$ lb. $\$ 6.00 ; 1 \mathrm{~b} . \$ 20.00$.

EXTRA EARLY DWARF ERFURT. A standard and excellent variety. It forms good, solid, pure white heads of fine quality. Pkt. 15c.; 1/4 oz. 50c.; oz. $\$ 1.75 ; 1 / \pm$ lb. $\$ 5.00 ; 1 b . \$ 18.00$.

VEITCH'S AUTUMN GIANT. A valuable late variety, admirably adapted for growing in the fall. The heads are large and white, and remain long fit for use. Pkt. 10c.; oz. 50c.; 1/4 lb. $\$ 1.50$; lb. $\$ 4.50$.

CAULIFLOWER PLANTS. Price, 50c. per 100; $\$ 4.00$ per 1,000 . See "Vegetable Plants," page 3.

\section{CORN SALAD OR FETTICUS.}

Sow early in the spring in rows one foot apart, and make successive sowings as often as desired. For very early salad sow in September and when severe weather comes on, cover with clean straw or leaves. Cover lightly and tread the rows to firm the soil. Work thoroughly and mater abundantly.

LARGE SEEDED. Pkt. 5c.; oz. 10c.; 1/1 1b. 15c.; lb. $45 \mathrm{c}$.

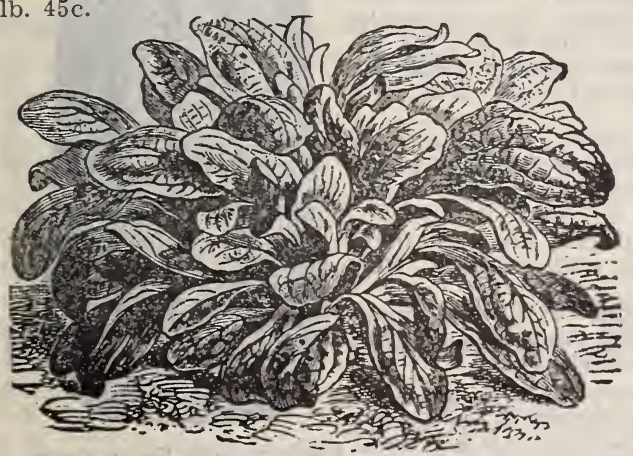

Corn Salad or Fetticus.

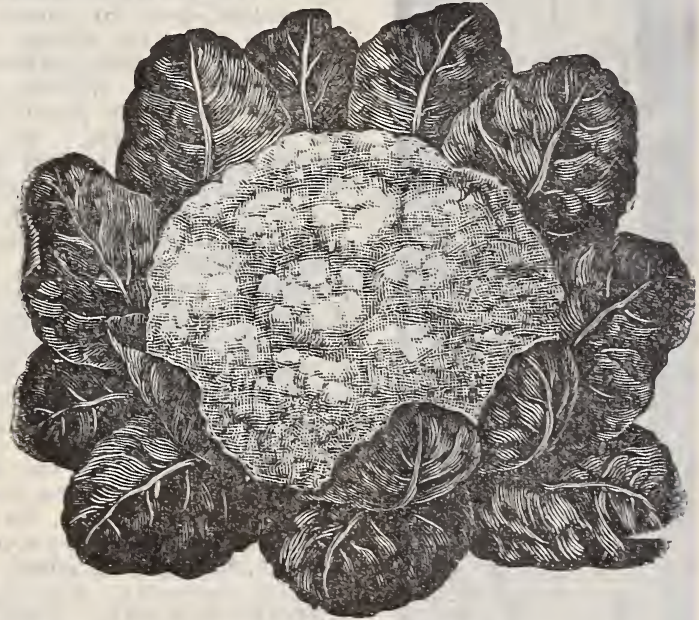

Wood's Earllest Snowball.

\section{BROCCOLI.}

WHITE CAPE. Closely resembles cauliflower, but is hardier, withstanding both heat and cold better. Heads white, close and compact. Pkt. 10c.; oz. 25c.; 1/4 lb. 75 c.; 1b. $\$ 2.75$.

\section{POP CORN.}

MAPLEDALE PROLIFIC. A very prolific corn, bearing large ears, the grains of which are a pearly white. Grow's about six feet high. When popped it is pure white and extremely tender. Pkt. 5c.; pt. 15c.; qt. 25c.; doz. ears, $25 \mathrm{c}$

RICE, This is probably the most popular and most generally used of all the pop-corns. It pops pure white, the quality is excellent, and it is always in demand. Pkt. 5c.; pt. 15c.; qt. $25 \mathrm{c}$; doz. ears, 25c.

QUEEN'S GOLDEN. This is a large-eared and handsome yellow pop-corn. The grains are large, pop perfectly white, and are exceedingly tender. The stalks grow about six feet high, and yield three or four ears each. Pkt. 5c.; pt. 15c.; qt. 25c.; doz. ears, 25c.

One pint of each variety of Pop-Corn for 35 cents. 


\section{CORN--Table and Sugar Varieties.}

Culture.-Plant the early corns in well-manured ground last of March or early in April. Sugar corn should not be planted until the ground gets warm. Cultivate often, and continue planting at intervals of about two weeks for a succession of roasting-ears. The early varieties of sugar corn can be planted during July or first part of August for late roasting-ears. One quart will plant two hundred hills, and from

Add 15 cents per quart, 8 cents per pint, if to be sent by mail.

The first five varieties are not strictly sugar corns, but make most excellent green corn, and are especially valuable on account of their earliness:

EXTRA EARLY ADAMS. The earliest white corn in cultivation; makes

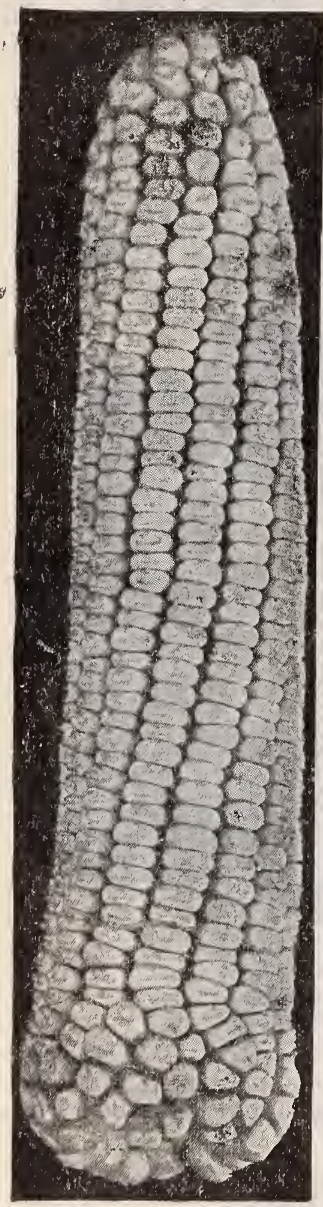

Trucker's Favorite.

a small ear and stalk, and can be planted close together. Pkt. 5c.; pt. 10c.; qt. 20c.; peck, $\$ 1.00$; bu. $\$ 3.50$; doz. ear $\approx$, 35c.

EARLY ADAMS, or BURLINGTON. Similar to the Extra Early Adams, but a little later, and makes larger ears. It is earlier and hardier than the sugar corns, and as :- makes a small stalk, can be planted very close. Pkt. 5c.; pt. 10c.; qt. 15 c.; peck, $\$ 1.00$; bu. $\$ 3.00$; doz. ears, 35 c.

TRUCKER'S FAVORITE. Never have re introduced a corn that has given more general satisfaction than this. $=0 \approx \approx$ second early to follow Early Adams it is unquestionably one of the best; or for planting late to mature quickly is it equally valuable. It is $\lesssim$ white corn, very good depth of grain, tender and sweet, and makes a most desirable size for roasting ears. Pkt.5c.; qt. 20c.; peck, 11.00 ; bu. $\$ 3.00$; doz. ears, 35c. GENTRY EARLY MARKET. A quick-maturing, white corn, making good roasting-ears to come in after Early Adams, and making larger ears. Aside from its worth as a table corn, it possesses merits of high order as a field variety, especially on light soils and thin land. It grows and matures very rapidly, making it valuable to plant early for market or home use, or to plant late, after it is too late to plant other varieties. Pkt. 5c.; pt. 10c.; qt. 15c.; peck, 60 c.; bu. $\$ 2.00$; doz. ears, $30 \mathrm{c}$.

RARE RIPE, or LONG WHITE FLINT. Known in some sections as the Hominy Corn, and is one of the best sorts for this purpose. The ears are long, and being of very quick growth, is desirable for second early market for roasting-ears. Pkt. 5c.; pt. 10c.; qt. 15c.; peck, 60c.; bu. $\$ 2.00$; doz. ears, 30c.

PREMO. The earliest sweet corn of all. A pure sweet corn from five to seven days earlier than the Extra Farly Adams, and of the most delicious sweet flavor. For full description, see "Seeds of Special Merit," page 5. Pkt. 10c.; qt. $30 \mathrm{c}$.; peck, $\$ 1.50$.

EXTRA ÉARLY CORY. Next to the Premo, this is the earliest of the sweet corns. The ears, while not as large as later sorts, are very sweet, and of best quality. Pkt. 5c.; qt. 25c.; pk. $\$ 1.25$.

BLACK MEXICAN. One of the sweetest and most delicious flavored of the sugar corns. Of quick maturity. Pkt. 5c.; qt. 25c.; peck, $\$ 1.25$.

CROSBY'S EARLY SWEET. An excellent early variety. Ears of good size and very sweet. Pkt. 5 c.; qt. 25 c.; peck, $\$ 1.25$.

COUNTRY GENTLEMAN. Although a comparatively new variety, its many good qualities have brought it rapidly into favor. The ears are not only of good size, but are produced in great abundance, frequently yielding three or four good ears to the stalk. Its table qualities are unsurpassed. Pkt. 5c.; qt. 25c.; peck, $\$ 1.25$; bu. $\$ 4.00$.

TRIUMPH SUGAR. The earliest of the large varieties; very prolific and sweet; intermediate between the preceding variety and Stowell's Evergreen. Pkt. 5c.; qt. 25c.; pk. $\$ 1.25$; bu. $\$ 4$. EGYPTIAN. A splendid sort for table and market, also largely used for canning. The ears are large and exceptionally sweet and rich. Pkt. 5c.; qt. $25 \mathrm{c}$; ; peck, $\$ 1.25$; bu. $\$ 4.00$.

STOWELL'S EVERGREEN. This has long been a great favorite. Its strong point is that it will remain in the green state longer than any other sort. Very tender and sugary. Pkt. 5c.; qt. 25c.; peck, $\$ 1.25 ;$ bu. $\$ 4.00$; doz. ears, $40 \mathrm{c}$.

EARLY MAMMOTH. Closely resembles the Late Mammoth, but is a little smaller, and about two weeks earlier. Of good size and quality. Pkt. 5c.; qt. $25 \mathrm{c}$.; peck, $\$ 1.25$; bu. $\$ 4.00$.

LATE MAMMOTH SUGAR. This is the latest, but largest of all the sugar corns. The ears grow to an immense size, and are of fine quality and flavor. Pkt. 5c.; qt. $25 \mathrm{c}$; ; peck, $\$ 1.25$; bu. $\$ 4.00$; dozen ears, $40 \mathrm{c}$. SEED CORN._- FIELD VARIETIES. See page 67 . Our seed corns for growing in the South than corn grown in the North and West. Experience has shown that corn grown in other sections requires to become

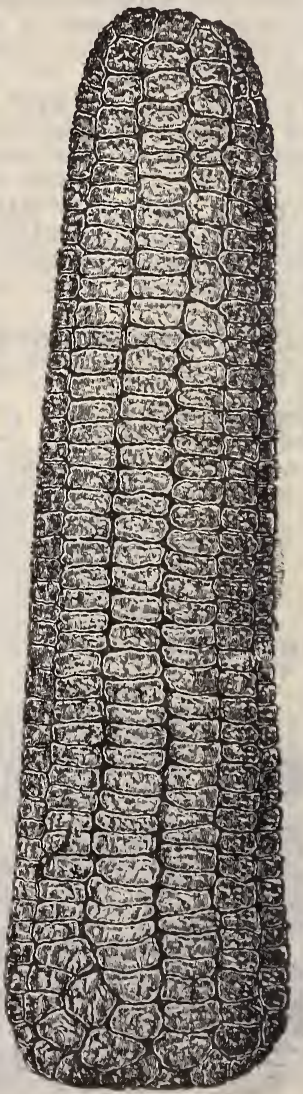
acclimated before it gives the best results. Our Field Seed Corns are all Virginia grown, and comprise the largest yielding and best varieties in cultivation. 


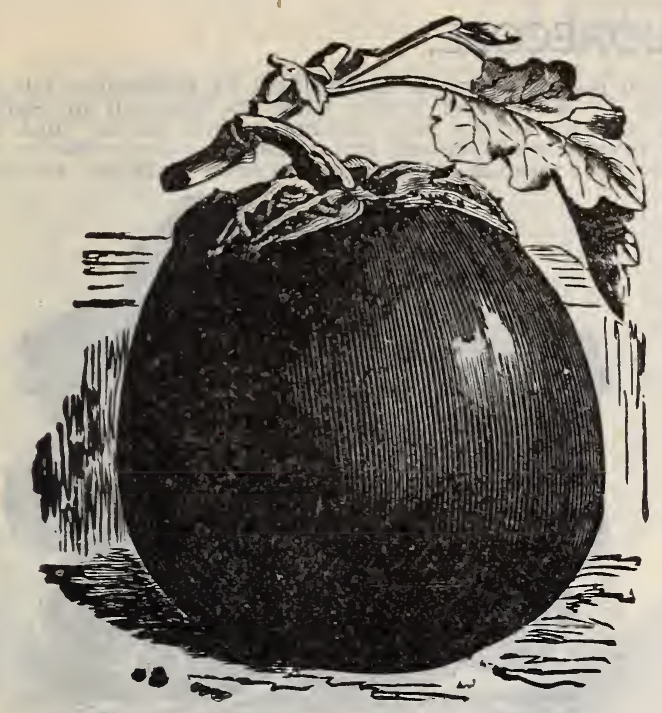

New York Improved Purple Egg Plant.

\section{ENDIVE.}

In the absence of lettuce during the latter part of the season, endive serves as an acceptable salad, and is well worthy of general cultivation, especially as it is of easy culture.

Culture.-Sow in August in drills eighteen inches apart, and when large enough, thin out to one foot apart. When nearly grown, tie up the outer leaves to blanch the heart. In dry seasons give plenty of water.

GREEN CURLED. The best variety for general use. Pkt. 5c.; oz. 10c.; 1/4 lb. 30c.; 1b. $\$ 1.00$.

\section{EGG PLANT.}

The Egg Plant is peculiarly well adapted to our Southern climate, and should be in every garden, It makes a most delicious dish.

Culture.-Egg Plants develop to the greatest perfection in a deep, rich loamy soil. In February or March sow in hot-beds and keep warm. When two inches high transplant to pots or to good, rich soil. About the middle of May set out three feet apart each way. and prótect from bugs by dusting lightly with Slug Shot. One ounce will produce about one thousand plants.

Insect Remedies.-For cut-worm use poisoned bran or poisoned cotton-seed meal, or wrap paper around the stem of the plants when setting out. For Colorado potato bug see under head of potatoes. FLORIDA HIGH BUSH EGG PLANT. For description of this splendid new shipping and market variety, see "Seeds of Special Merit," pase 5. Pkt. 10c.; oz. 40c.; 1/4 lb. $\$ 1.00$; lb. $\$ 3.50$. NEW YORK IMPROVED PURPLE. The standard and leading market variety; fruit large, smooth, deep purple; early and productive. Pkt. 5c.; oz. 25c.; 1/4 lb. 75c.; lb. $\$ 2.50$.

EGG PLANTS. Ready about May 1st. 20c. per doz.; $\$ 1.00$ per hundred.

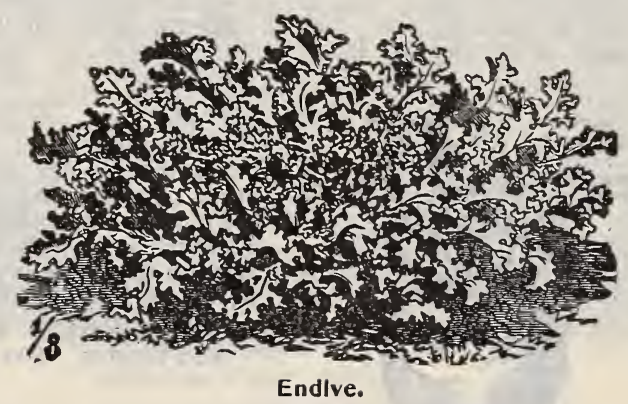

\section{MANGELS, STOCK, OR SUGAR BEETS.}

Culture.-Mangels make one of the healthiest, richest, and most nutritious hog and cattle feeds that can be grown. Very much superior to turnips, and should be largely grown by every farmer. For best results, Mangels should be sown end of March or early in April, although they can be put in in May or June. Earlier seedings will, however, yield a much heavier crop. Sow at the rate of six pounds per acre, in rows two and a half to three feet apart, and cultivate as for corn. After the first cultivation, thin with a hoe to one plant to every six inches in the row. Frequent cultivation is most desirable, especially

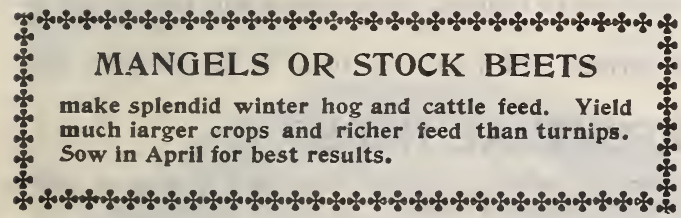

MAMMOTH PRIZE LONG RED. Grows to an immense size, and will make a larger yield to the acre than any other variety, although it does not keep as well as the globe-shaped sorts. The Globe varieties will keep until March or April, but the Long Red kinds should be used before January. Oz. 5c.; 1/4 lb. 15c.; lb. 25c.; 5 lbs. and over, $20 \mathrm{c}$. per lb.
YELLOW or ORANGE GLOBE. Specially adapted for light soils. Roots are of large size, and splendid keepers, and of first-class nutritive qualities. Oz. 5c.; 1/4 lb. 15c.; 1b. 25c.; in $5 \mathrm{lb}$. lots and over, 20c. per $1 \mathrm{~b}$.

GOLDEN TANKARD. Rich yellow color, sweet flavor, and yields heavy crops of fine-shaped roots. One of the best milk-producing sorts. Oz. 5c.: $1 / 4$ 1b. $15 \mathrm{c}$; $1 \mathrm{~b} .25 \mathrm{c}$; in $5 \mathrm{lb}$. lots and over, 20c. per $1 \mathrm{~b}$.

SILESIAN SUGAR. Will make equally as large a yield as the globe-shaped stock beets, and contains more saccharine matter. Very productive, and a good keeper. Oz. 5c.; 1/4 lb. 15c.; 1b. 25c.; $5 \mathrm{lb}$. lots and over, 20c. per $\mathrm{lb}$.

\section{FRUIT TREES, GRAPE VINES, AND ALL NURSERY STOCK,}

which we will mail on application. Our Nursery Stock is home grown, acclimated stock, and firstclass in every respect. For planting in this section and further South, experience has proven that better results are obtained from stock grown in this section than from stock obtained in the North and West. If you desire to purchase large quantities of Nursery Stock, send us a list of your requirements for'special nrices. 


\section{KALE OR BORECOLE.}

Culture.-Sow either broadcast or in drills eighteen inches apart, from the first of September till the middle of October. It may also be sown in February or March, at which time the Smooth or Spring Kale is best. Of late years the latter has been largely sown in the fall, making greens earlier than the winter sorts. Protect with straw or coarse litter in severe weather, and it can be cut during the winter and spring. Sow winter sorts at the rate of three or four pounds to the acre. Spring Kale can be sown broadcast at the rate of eight pounds to the acre, or four or five pounds in drill. It is much the best to sow the winter kinds in drills and give some cultivation.

CURLED SIBERIAN (Blue Kale). The old standard winter variety. The leaves are a bright green color, tinged with purple, and beautifully curled and delicate in flavor. In the latitude of Richmond it will stand throughout the winter without protection. Oz. 5c.; 1/1 lb. 15c.; lb. 40c.; 5 lbs. and over, $35 \mathrm{c}$. $1 \mathrm{~b}$.

DWARF GREEN CURLED SCOTCH, or NORFOLK. One of the most popular shipping sorts; very largely used in the Norfolk trucking district. The leaves are of a bright green color, beautifully curled. Should be sown in rows in August and September. Pkt. 5c.; oz. 10c.; $1 / 1 \mathrm{lb}$. $20 \mathrm{c}$; $1 \mathrm{~b} .60 \mathrm{c}$.

SPRING or SMOOTH KALE. A hardy, quickgrowing, smooth-leaved variety, which makes a fine salad. The best for sowing in the spring. Large pkt. $5 \mathrm{c}$.; $1 \mathrm{~b}$. $15 \mathrm{c}$;; 2 lbs. for $25 \mathrm{c}$; $10 \mathrm{lbs}$. and over, $10 \mathrm{c}$. per $1 \mathrm{~b}$.

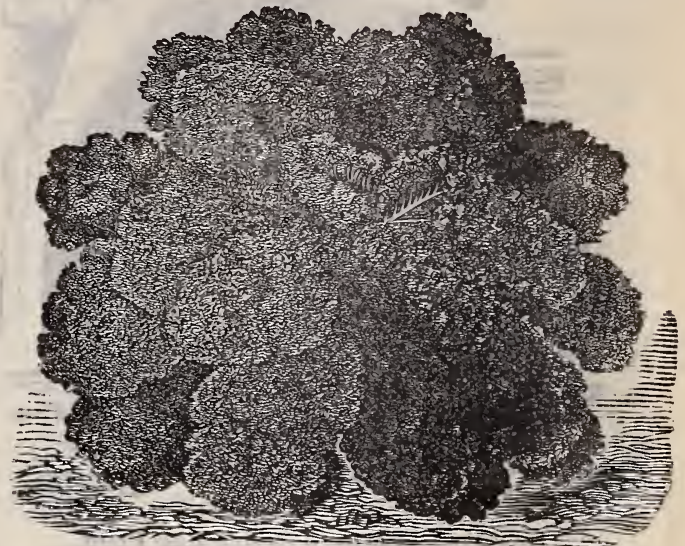

Dwarf Green Curled Scotch Kale.

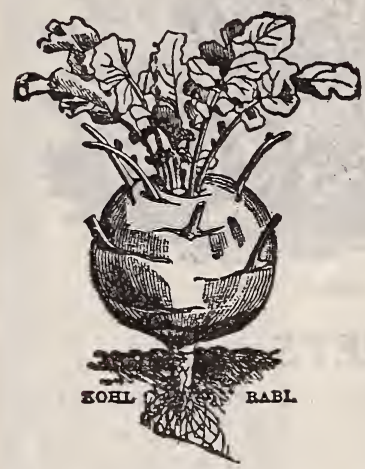

KohI Rabi.

\section{KOHL RABI.}

Culture.-An excellent vegetable and should be grown in every garden. It is prepared for the table like turnips, and is very palatable and tender, with a fine and delicate flavor. For early use, sow in April in rows eighteen inches apart, and thin out to eight inches between the plants. For winter use, sow in June and July, and thin out as above. One ounce will sow two hundred feet drill.

EARLY WHITE VIENNA. The best market and table sort; flesh white and tender. Pkt. 5c.; oz. $20 \mathrm{c}$; $1 / 4$ 1b. $60 \mathrm{c}$.; 1b. $\$ 2.00$.

\section{LEEK.}

Culture.-The leek is generally considered superior to the onion for soup flavoring, etc. Sow as early as practicable in the spring in a light, rich, moist soil, in drills half an inch deep. When six or eight inches high trim off the tops and roots, and transplant to rows one foot apart and six inches apart in the row, setting them three or four inches deep and earthing up as they grow, so that the necks will become well blanched. May also be sown in cold frames in September, and the young plants transplanted in the fall or early spring to where they are to remain. One ounce will sow about one hundred feet of drill.

LARGE FLAG. Hardy and productive. The standard variety. Plkt. 5c.; oz. 10c.; 1/4 lb. $30 \mathrm{c} . ; 1 \mathrm{~b} .90 \mathrm{c}$.

\section{SWEET POT AND MIEDICINAL HERBS.}

Culture.-Sow in spring, in shallow drills twelve inches apart. Gather on a dry day, just before they come into bloom, dry in the shade, and put into closely corked bottles.

ANISE. Cultivated for seasoning or garnishing, and used medicinally. Pkt. 5c.; oz. 10c.

BALM. A hardy perennial, used medicinally in cases of fever. Pkt. 5c.; oz. $20 \mathrm{c}$.

BASIL SWEET. The seeds and small tops are used largely in flavoring soups, etc. Pkt. $5 \mathrm{c}$; oz. $15 \mathrm{c}$.

BENE. Excellent for cholera infantum, etc. Pkt. 5c.; oz. $15 \mathrm{c}$.

CARRAWAY. Seed aromatic. Used in pastry, confectionery, and for flavoring. Pkt. 5c.; oz. 10c.; $1 / 4$ lb. $25 \mathrm{c}$.

CATNIP. Leaves are used, both green and dried, for seasoning. Pkt. 10c.; oz. 30c.

DILL. The leaves are used in soups, sauces and pickles. Pkt. 5c.; oz. 10c.; $1 / 4$ lb. 20 c.; lb. 50 c.
HOREHOUND. The leaves are used for seasoning, and also in making of cough and candy remedies. Pkt. 5c.; oz. 20c.

FENNEL. A perennial which is excellent for fish sauces. Pkt. 5c.; oz. 10c.

LAVENDER. A popular aromatic herb. Pkt. $5 \mathrm{c}$.; oz. $15 \mathrm{c}$.

SUMMER SAVORY. Used as a culinary herb. Pkt. 5c.; oz. 10c.

SWEET MARJORAM. Used in soups, etc. Pkt. $5 \mathrm{C} . ;$ oz. $15 \mathrm{c}$.

THYME. For seasoning soups, and stuffings. Pkt. 5c.; oz. $20 \mathrm{c}$; $1 / 4$ lb. $70 \mathrm{c}$.

SAGE. Used for seasoning, stuffing and sauces. Pkt. 5c.; oz. 15 c.; $1 / 1$ lb. 35 c.; lb. $\$ 1.25$. 


\section{LETTUCE.}

Throughout the trucking sections of the South the growing of lettuce in hot-beds and cold frames has reached large proportions. Lettuce shipped during the winter and early spring usually proves very remunerative.

Culture.-The quality of lettuce depends largely on its quick growth. and this can only be obtained by transplanting to rich, mellow, deeply worked soil, and cultivating well. For early crop, sow under glass in January or February, and transplant in the spring. For a succession, sow at intervals of three
weeks until end of April. For autumn use, sow in July. For fall planting, sow the hardy varieties in September, and transplant when large enough. Protect with straw, leaves or litter, and they will stand the winter, and head up in the spring; or they can be transplanted to cold frames nine inches apart Two crops can be grown under the same glass in one season. One ounce of seed will sow two hundred feet of drill, and produce about one thousand five hundred plants.

Insect Remedies.-Plant-lice sometimes interfere considerably with lettuce grown in hot-beds or greenhouse. The remedies are the application of tobacco dust to plants and soil or fumigation with tobacco. For the green lettuce-worm the remedy is pyrethum mixed with not more than three times its bulk of flour and dusted on the plants while the dew is on.

WOOD'S CABBAGE. Introduced by us several years ago, it has proved to be one of the best and most popular varieties in cultivation. It makes a splendid, large, hard head, very hardy, and exceedingly slow in running to seed. Is a particularly desirable variety for the home and market garden. Pkt. 5c.; oz.

$15 \mathrm{c}$; $1 / 4$ lb. $50 \mathrm{c}$.; lb. $\$ 1.50$.

BIG BOSTON. Our strain of this is very superior, and we supply it in very large quantities to the most successful lettuce growers in the South. It is more largely grown than any other for shipping, and is one of the best for forcing, as well as for out-door culture, making a large, solid head, which stands shipping remarkably well. Pkt. 5c.; oz. 10c.; $1 / 1 / \mathrm{lb}$. 30c.; lb. $\$ 1.00$.

CALIFORNIA CREAM BUTTER. Largely grown by shippers to Northern markets. Of distinct shape, heading up like a cabbage, and almost as solid. Color light green, almost white; the flavor rich and buttery, and very tender. Specially recommended for forcing for spring and summer use. Pkt. 5c.; oz. 10c.; $1 / 4$ lb. 30c.; lb. $\$ 1.00$.

CRISP-AS-ICE. When grown quickly the leaves of this are exceedingly brittle and tender. Heads large, leaves thick, and nicely crimped, the outer leaves touched with bronze, making a very pretty lettuce. Pkt. 5c.; oz. 15c.; 1/4 lb. 40c.; lb. $\$ 1.25$.

TRIANON COS, or CELERY LETTUCE. Has no equal for quality, but must be sown early in a hot-bed for best results. The heads are Iong and conical, often measuring ten inches high by eighteen inches in circumference. A short while before cutting, tie up the leaves, and they

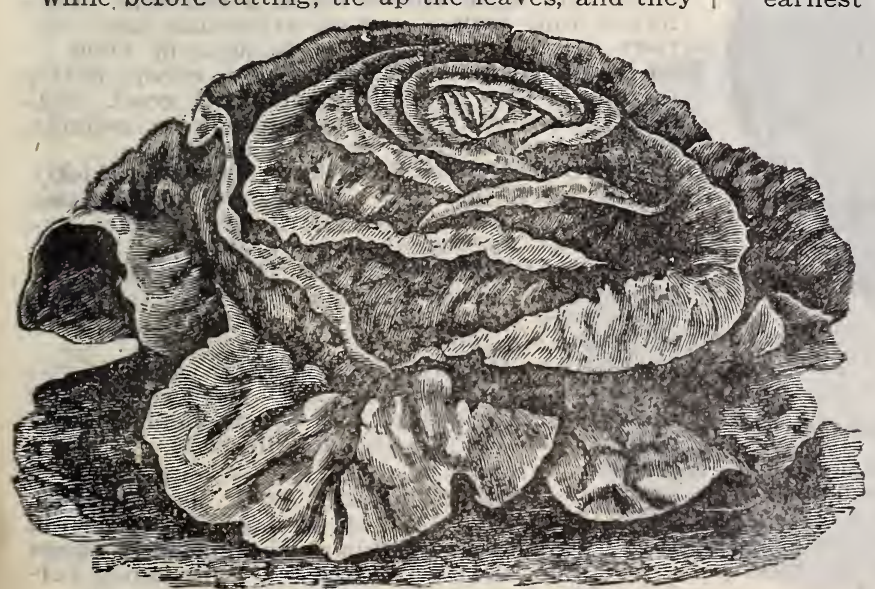

Big Boston. will blanch quickly and form solid heads, becoming as crisp as celery stalks. Pkt. 5c.; oz. 10 c.; $1 / 4$ lb. 30 c.; lb. $\$ 1.00$.

DEACON. A fine forcing lettuce; makes large, dense heads, with thick leaves of superior flavor. It forms a solid heart, blanching to a rich yellow color; crisp and tender. Pkt. 5c.; oz. 10c.; $1 / 4$ lb. 30c.; lb. 90c.

BOSTON MARKET, or WHITE SEEDED TEN. NISBALL. A splendid early lettuce, forming fine, hard heads of the best quality. One of the earliest heading sorts, and very popular, both for home use and market. Pkt. 5c.; oz. 10c.; 1/4 lb. 30c.; 1b. 90c.

BLACK SEEDED TENNISBALL. An excellent forcing lettuce; forms close, hard heads; tender, crisp, and a fine table variety. Pkt. 5c.; oz. 10c.; $1 / 4$ lb. 30c.; lb. 90c.

IMPROVED HANSON. One of the best summer lettuces. Grows to a large size; very solid and refreshingly crisp and tender. Pkt. 5c.; oz. 10c.; $1 / 4$ lb. 30c.; lb. $90 \mathrm{c}$.

DUTCH BUTTERHEAD. An old favorite; makes cabbage-shaped heads of excellent quality. Pkt. 5c.; oz. $10 \mathrm{c} . ; 1 / 4$ lb. $30 \mathrm{c}$; $1 \mathrm{lb} .90 \mathrm{c}$.

EARLY CURLED SIMPSON. Makes a curly, loose head; early and tender. Pkt. 5c.; oz. 10c.; 1/1 lb. 30c.; lb. 90c.

BROWN DUTCH. The hardiest of lettuces, and best for out-door fall planting; makes a good, solid head. Pkt. 5c.; oz. 15c.; 1/4 lb. 40c.; lb. $\$ 1.25$. 


\section{CANTALOUPE, or MUSK MELON.}

EXTRA EARLY HANOVER. This variety orig1nated in this section, and is unquestionably the best extra early cantaloupe in cultivation. While being extra early in maturity, it also makes a good sized melon, averaging considerably larger than the Netted Gem. It is round in shape, slightly flattened at the ends, of excellent quality, and a fine shipping and market melon. Wherever it has been grown it has become very popular, and the demand for the seed has increased rapidly each year, so much so that it has always exhausted our supply before the season was over. Pkt. 5c.; oz. 10c.; 1/4 1b. 35c.; lb. $\$ 1.20 ; 5 \mathrm{lbs}$. and over at $\$ 1.10 \mathrm{lb}$.

(ROCKY FORD NETTED GEM. Our stock is grown in the famous Rocky Ford melon district, and is a particularly valuable strain for shippers. It is uniform in size, thickly netted, distinctly ribbed, firm fleshed and of most delicious flavor. Pkt. 5c.; oz. 10c.; $1 / 4$ lb. 30c.; lb. 90c.

WOOD'S NETTED GEM. A thorough-bred strain of Netted Gem, which we have been selecting and improving for years. Our stock runs a little larger in size than the Rocky Ford strain, and, both in appearance and table qual:ties, will produce more high grade fruits to the acre than any other stock of Netted Gem we have ever grown; and we believe that we have to-day the best strain of Netted Gem Cantaloupe offered anywhere. Pkt. 5c.; oz. 10c.; 1/4 lb. $35 \mathrm{c}$.; lb. $\$ 1.20 ; 5 \mathrm{lbs}$. and over $\$ 1.10$ per $1 \mathrm{~b}$.

WOOD'S PERFECTION. This is another of our own introduction, which has proved to be of very superior merit. It is one of the best of large cantaloupes for main crop. The flesh is thick, of a beautiful deep, rich green color, turning to a salmon; well ribbed and thickly netted; unusually street and luscious. A splendid cantaloupe, whether for home use, market or shipping. Pkt. 5c.; oz. 10c.; 1/4 lb. 35c.; lb. $\$ 1.20$.

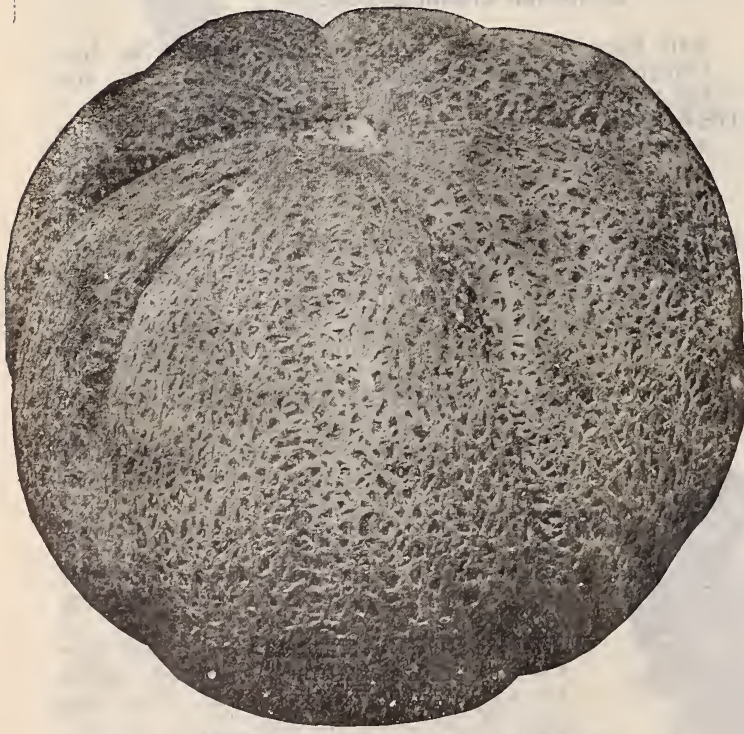

Extra Early Hanover. (From a Photograph.)

BALTIMORE, or ACME. During the season this melon is always in demand for the best hotels and restaurants, and finds ready sale. It is oval-shaped, and has very thick, green flesh of the finest flavor. One of the best sorts for shipping. Pkt. 5c.; oz. 10c.; 1/4 1b. 30c.; 1b. $\$ 1.00$.

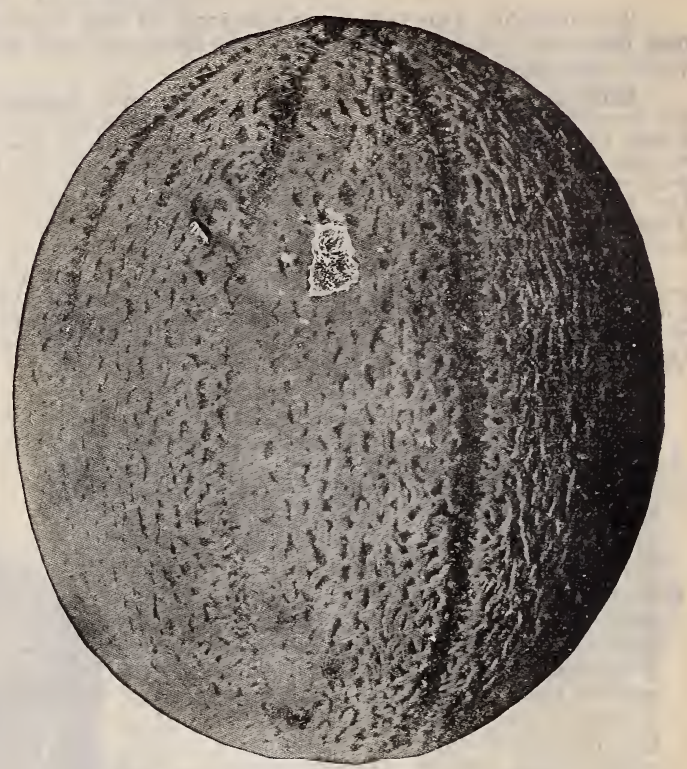

Wood's Netted Gem. (From a Photograph.)

JENNY LIND. An extra early variety. Small size, and makes very nice cantaloupes, of good flavor. Largely used by shippers; also a desirable variety for the home and nearby market. Pkt. 5c.; oz. 10c.; 1/1 1b. 25c.; 1b. $85 \mathrm{c}$.

EXTRA EARLY HACKENSACK. This sort resembles the Large Hackensack in shape, but is fully ten days earlier. Has a roughly-netted skin and dark thick flesh. A good market variety. Pkt. 5c.; oz. 10c.; $y_{t}$ lb. 30c.; lb. $\$ 1.00$.

SKILMAN'S NETTED NUTMEG. A large sized cantaloupe, thickly netted, and of excellent flavor. Medium early. Pkt. 5c.; oz. 10c.; 1/4 lb. 30c.; 1b. 90c.

LARGE GREEN CITRON. An old popular variety, of excellent flavor. Flesh and skin deep green, thickly netted. Pkt. 5c.; oz. 10c.; 1/4 lb. 30 c.; 1 b. $90 \mathrm{c}$

OSAGE, or MILLER CREAM. A splendid melon, of medium size oval-shaped, salmon-colored flesh, very dark, almost black, green skin. Fine flavor, and makes a most attractive table variety. Pkt. 5c.; oz. 10c.; $1 / 4$ lb. 30c.; 1b. $\$ 1.00$.

EMERALD GEM. Similar to above, except flatter in shape. The flavor is particularly good. Salmon fleshed melons are becoming very popular. Pkt. 5c.; oz. 15c.; 1/4 lb. 50c.; 1b. $\$ 1.50$.

CHAMPION MARKET. A large-growing, thickly netted sort, of very handsome appearanoe, Flesh light green. An attractive market van riety. Pkt. 5c.; oz. 10c.; 1/4 lb. 30c.; lb. $\$ 1.00$.

LARGE HACKENSACK, or TURK'S CAP. A popular and large-growing medium early sort. Flesh very thick and sweet. Pkt. 5c.; oz. 10c.; $1 / 4$ lb. 30c.; lb. 90c.

MONTREAL MARKET NUTMEG. One of the largest melons for main crop. Very showy and attractive; thick flesh and of excellent quality. Pkt. 5c.; oz. 15c.; 1/4 lb. 40c.; lb. $\$ 1.20$.

BANANA. Grows 18 to 24 inches long; quite a, curiosity. Pkt. 5c.; oz. 10c.; 1/4 lb. 30c.; lb. $\$ 1.00$.

GLASS MELON. An old-fashioned preserving sort. The fruits are about the size and shape of a lemon, the color of rind a light lemon yellow. Pkt. 5c.; oz. 10c.; 1/4 lb. 30c.; 1b. $\$ 1.00$. 


\section{WATERMELON.} Culture.-Cultivate exactly like cantaloupes, but give more room, say ten to twelve feet apart each
way. They should not be planted near pumpkins, gourds, or their species, as they will hybridize and injure the flavor of both. One ounce will plant thirty hills; three pounds will plant an acre.

\section{IMPROVED GEORGIA RATTLE}

SNAKE. The old Rattlesnake has always been regarded as a fine melon. Our strain is the result of careful selection by an experienced melon grower through several years of careful and watchful work. The illustration gives a good idea of its general appearance. The rind is thin and tough, the flesh deep scarlet, the flavor unsurpassed by any other sort. We strongly recommend it both for shipping and home use, combining to an unusual degree splendid shipping and table qualities. Our improved stock is very much

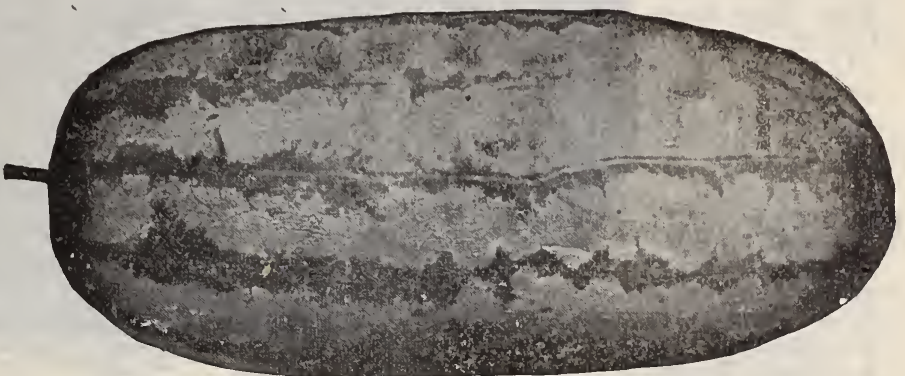

Improved Georgia Rattlesnake.

superior to the ordinary Georgia Rattlesnake Watermelon. Pkt. 5c.; oz. 10c.; 1/4 1b. 30 c.; lb. $\$ 1.00$.

HARRIS' EARLIEST. For full description of this splendid new Extra Early Watermelon, see "Seeds of Special Merit," page 6. Pkt. 10c.; oz. 15c.; $1 / 4$ lb. 40c.; lb. $\$ 1.00$.

DARK ICING. A splendid extra early melon, weighing from twenty-five to thirty pounds. Dark green rind; the flesh is of a deep rich red color, and of the most delicious flavor. Pkt. 5c.; Oz. 8c.; $1 / 4$ lb. 15c.; 1b. $45 \mathrm{c}$.

PEERLESS, or WHITE SEEDED ICE-CREAM. A most desirable home-market melon, specially recommended both for its quality and productiveness. Medium early, fruit oblong, light, mottled green, flesh bright scarlet, solid to the centre, melting and delicious. Pkt. 5c.; oz. 8c.; $1 / 4$ lb. $15 \mathrm{c}$; $1 \mathrm{~b}$. $45 \mathrm{c}$.

EDEN. Originated by Mr. C. H. Mathis, one of the largest melon growers in the South. It is a successful cross of the Kolb Gem and Rattlesnake, combining the good shipping qualities of the Kolb Gem with the splendid table qualities of the Rattlesnake. It is similar in shape and appearance to the Kolb Gem, excepting that it has a brighter stripe, and is a little more attractive in appearance. Is becoming popular wherever grown. Pkt. 5c.; oz. 10c.; $1 / 4$ lb. 20c.; lb. $60 \mathrm{c}$.

THE JONES. Our stock of this has been very much improved by careful selection for several years past, and we unhesitatingly recommend it as one of the best watermelons in our list. It grows to a large size; skin of a dark green color, with indistinct stripes. Flesh bright red, exceedingly sweet, juicy, and melting. TVe recommend it very strongly, both as a market melon and a splendid melon for home use. Pkt. 5c.; oz. 8c.; 1/4 lb. $20 \mathrm{c}$; 1b. $50 \mathrm{c}$.

JOE JOHNSON. An old favorite, which makes friends wherever grown. The melons run very uniform in size, with very few culls. An excellent market and shipping melon as well as for home use. Pkt. 5c.; oz. 8c.; $1 / 4$ lb. 20c.; lb. 45c.

DUKE JONES. A Southern variety. Extra early, large, very prolific, and of finest flavor. Pkt. 5 c.; oz. 8c.; 1/4 lb. 15c.; lb. 40 c.
JACKSON. For home use the Jackson is unsurpassed. Although not extra large, the delicious flavor more than compensates for want of size. Color light green, rind very thin, flesh firm and sweet. Pkt. 5c.; oz. 10c.; 1/4 lb. 25c.; 1b. 75c.

CAROLINA BRADFORD. A favorite above all others in sections where it has been grown. It makes a strong, healthy growth of vine, and is very productive. The melons grow to a large size; elongated in shape; rind dark green with darker stripe; flesh red, and remarkably tender and sweet. An excellent melon for home use. Pkt. 5c.; oz. 10c.; $1 / 4$ lb. 20c.; 1b. $65 \mathrm{c}$.

GIRARDEAU'S TRIUMPH. One of the best market and shipping melons in cultivation. It is early, prolific, and averages very large. Its fine appearance makes it a ready seller in any market. The rind, like that of the Duke Jones, is of dark green color with indistinct stripe. Flesh solid and sweet. Pkt. 5c.; oz. 10c.; 1/4 lb. 20c.; lb. 50c.; in 5-lb. lots and over, $45 \mathrm{c}$. per $1 \mathrm{~b}$.

GIRARDEAU'S NEW FAVORITE. Resembles the Florida Favorite, but is larger. It is early, productive, tender and crisp, has bright red, very sweet flesh. The rind is thin and too tender to stand shipment long distances, but is a splendid melon for home use or near-by market. Pkt. 5c.; Oz. 8c.; $1 / 4$ 1b. 15c.; 1b. 45 c.

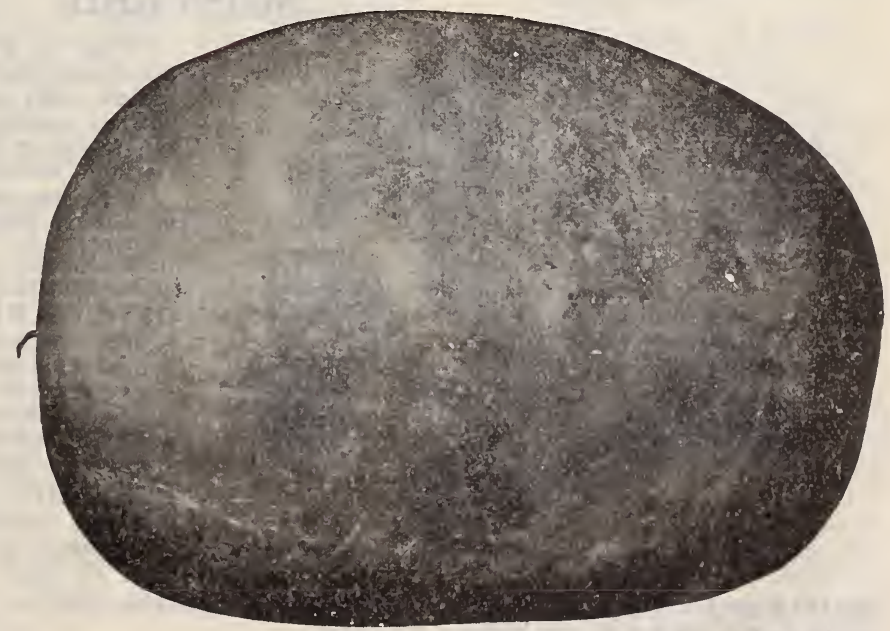

The Jones Watermelon。 
FLORIDA FA. VORITE. This has long been a prime favorite for home consumption. It ripens early, has dark skin with light green stripes and crimson flesh; exceedingly sweet. Pkt. 5c.; oz. $8 \mathrm{c}$.; $1 / 4$ lb. 15 c.; lb. $45 \mathrm{c}$.

BLUE GEM. Will average larger than the Kolb Gem, and as a table melon, is far superior. Of a dark bluish green color, very uniform in size

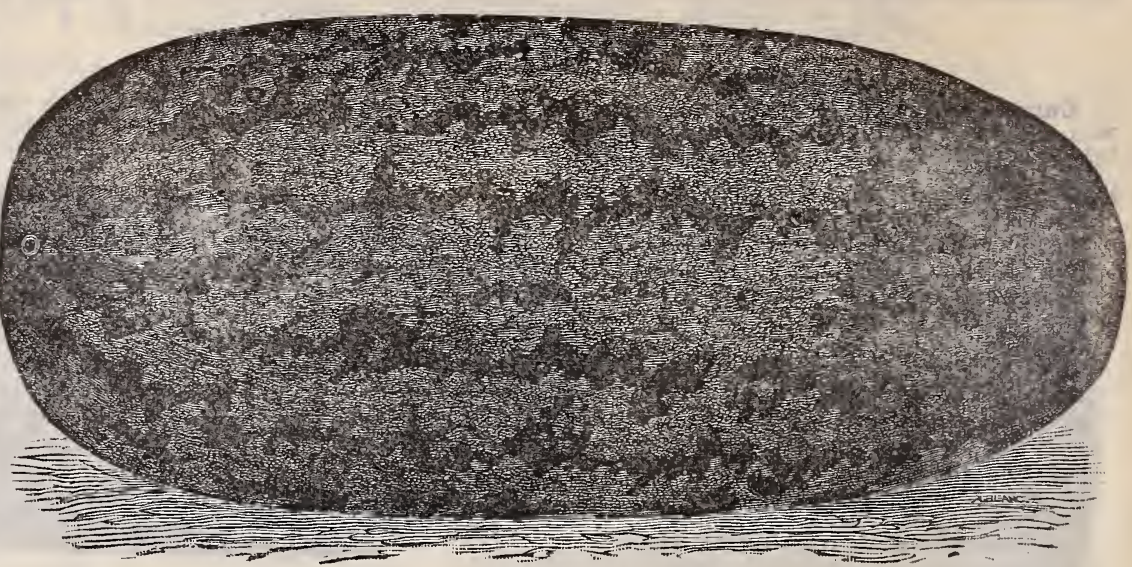
and shape, crimson flesh, equal to any as a shipper, and shows up well in bulk. Pkt. $5 \mathrm{c}$.; oz. $8 c . ; 1 / 4$ lb. 15c.; lb. 40c.; 5-lb. lots and over, $35 \mathrm{c}$. per lb.

KLECKLEY'S SWEETS. This is claimed to be the very sweetest of all large watermelons. It is undoubtedly of fine eating qualities, and a splendid melon for home use or nearby market, but on account of thin rind is not a good shipping melon. Color of rind dark green, flesh bright scarlet, with broad solid heart, crisp, sugary and melting. Melons large size, and of handsome appearance, and uniformly superior quality. Pkt. 5c.; oz. 10c.; $1 / 4$ lb. $25 \mathrm{c}$; 1b. $75 \mathrm{c}$.

JORDAN'S GRAY MONARCH, or LONG LIGHT ICING. One of the largest of melons, and a fine shipper, carrying well for long distances. It is long in shape, with skin of mottled rray color, and bright crimson flesh. The flavor is sweet and delicious. Pkt. 5c.; oz. 8c.; $1 / 4$ lb. 15c.; lb. $45 \mathrm{c}$.

KOLB GEM. For shipping purposes this is more

lorida Favorite Watermelon.

largely grown than any other sort. It grows large, uniformly round, and its keeping qualities are unequalled. The flesh is bright red, solid anci of good flavor. Pkt. 5c.; oz. 8c.; $1 / 4$ lb. 15c.; lb. $30 \mathrm{c}$; ; in 5 -1b. lots and over, 27c. per $1 \mathrm{~b}$.

DIXIE. A cross of the Kolb Gem on the Mountain Sweet, a good shipping melon. It ripens early, the vines are strong and vigorous, and the fruit large. Pkt. 5c.; oz. 8c.; 1/4 lb. 15c.; Ib. $40 \mathrm{c}$.

PRIDE OF GEORGIA. One of the largest melons in our list. Dark green rind; oval-shape; meat bright red. Unsurpassed as a table melon. Pkt. 5c.; oz. 8c.; 1/4 lb. 15c.; lb. 40 c.

MOUNTAIN' SWEET. This popular old melon still holds its own, and is particularly desirable for growing in mountainous districts, or on heavy soils. Fruit oblong; rind thin; flesh red, sweet and solid. Pkt. 5c.; oz. 8c.; 1/4 lb. 15c.; Ib. $40 \mathrm{c}$.

CITRON (for preserving). Pkt. 5c.; oz. 10c.; 1/1 lb. $20 \mathrm{c}$; ; lb. $50 \mathrm{c}$.

\section{MUSHROOM SPAWN.}

We will send special circular giving culture of mushrooms to any one interested, on application.

ENGLISH SPAWN. 15c. lb., $10 \mathrm{lbs}$. and over at $10 \mathrm{c}$. lb. If to be sent by mail, add 10c. per lb. for postage.

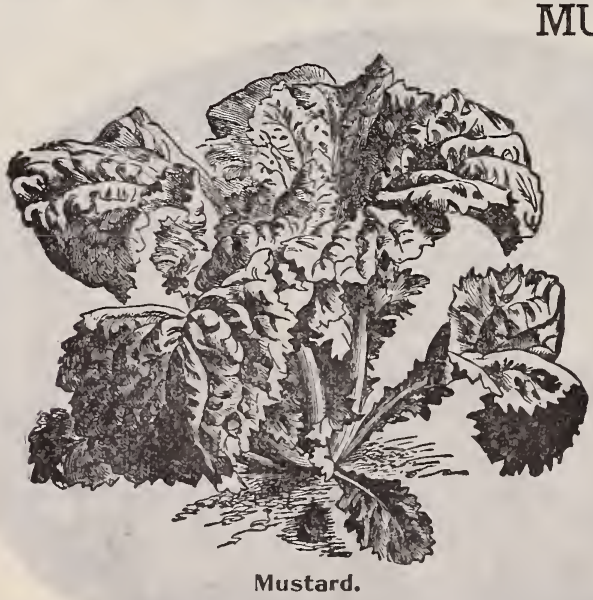

This is grown to quite a large extent in the Southern States. It is used the same as Spinach, or boiled with meat as greens. The white or yellow seeded variety is cultivated chiefly for medicinal purposes or pickling. Southern Giant Curled and Ostrich Plume are best for general use.

Culture.-Sow during February, March or April, or during September or October, either broadcast or in row's six inches apart. Cut when about three inches high. Sow one ounce to eighty feet of drill, or broadcast at the rate of five or six pounds per acre.

OSTRICH PLUME MUSTARD. This new variety originated in the South, and is one of the most desirable mustards in cultivation. The leaves are exquisitely crimped, ruffed and frilled, and make an excellent table garnishing. It is of superior flavor when cooked, and very popular wherever grown. Pkt. 5c.; oz. 10c.; 1/1 lb. 20c.; 1b. 60c.

SOUTHERN GIANT CURLED. A favorite variety, much esteemed in the South. Very succulent, pungent, and of sweet flavor. Pkt. 5c.; oz. 10c.; $1 / 4$ lb. $20 \mathrm{c}$; 1b. $50 \mathrm{c}$.

WHITE or BLACK. Used for salad. Oz. 5c.; $1 / 4$ lb. $10 \mathrm{c}$; $1 \mathrm{~b} .25 \mathrm{c}$.

MUSTARD SEED for Pickling. Lb. $15 \mathrm{c}$. 


\section{NASTURTIUM, OR INDIAN CRESS.}

The flowers and young leaves are used as a salad. The seed pods, with foot-stalks attached, are gathered while green and tender and used as pickle. They make a most tender and delicious relish, similar to capers. Plant April or May.

TALL MIXED. The tall varieties require to be planted either alongside of fences or trellis work, or staked, to do best. Price, per pkt. 5c.; oz. 10c.; $1 / 4$ lb. $25 \mathrm{c}$.

DWARF. These make very ormamental plants, and are much easier to grow than the tall kinds. Price, pkt. 5 c.; oz. $10 \mathrm{c}$; $1 / 1$ lb. $25 \mathrm{c}$.

\section{OKRA, OR GUMBO.}

This vegetable should be much more generally grown, as it makes a fine flavoring for soups, stews, and gravies. Also gives a good flavor to canned tomatoes. Should be gathered and used while young, and may be kept for winter use by drying the young pods on a string.

Culture.- When the ground has become warm, sow thickly in drills three feet apart, and when large enough, thin out to eight inches apart in the rows. To keep for winter use, slice the pods when young and tender into narrow rings; string and hang in.the shade to dry. One ounce will sow thirty feet of drill. PERKINS' MAMMOTH PODDED. A distinct WHITE VELVET. Bears round, white, smooth valuable new Okra. Its productiveness is sim- pods, unlike other varieties, which are ridged or ply wonderful. The pods shoot out from the stalk within three inches of the ground, and the whole plant is covered with them to the extreme height of the plant. The pods are of an intense green color, of unusual length, eight or nine inches, and do not get hard, as is the case with other Okras. It is also very superior for use by canners. Packet, 5c.; oz. 10c.; 1/4 lb. 20c.; lb. $50 \mathrm{c}$. square-edged. The pods are of extra large size, and are produced in great abundance. Pkt. 5c.; oz. 8c.; 1/4 lb. 15c.; 1b. 35c.

IMPROVED DWARF PROLIFIC, OF DENSITY. Of dwarf growth, but immensely productive. Pkt. 5c.; oz. 8c.; $1 / 4$ lb. $15 \mathrm{c}$; 1b. $35 \mathrm{c}$.

TALL GREEN. Produces in great abundance dark green pods of the best quality. Pkt. $5 \mathrm{c}$.; oz. 8c.; $1 / 1$ lb. 15c.; 1b. 35c.

\section{ONION SETS.}

If to be sent by mail, add 10c.oper quart for postage.

Culture.-Plant four inches apart, in rows about half an inch deep and one foot between the rows, but do not cover the sets entirely. This applies to all varieties except the Potato Onion, which should be planted in rows two feet apart and nine inches apart in the row, and then covered with about one inch of soil. All varieties can be set out in the fall as well as the spring. Fall planting of onions is succeeding very well in the South, and should be more generally practiced.

YELLOW POTATO ONIONS (also called the Hill Onion). This makes a large-sized onion, of mild flavor and excellent cooking qualities. Is of a reddish yellow color, and a good keeper. This variety never makes seed, but divides up from the root, one medium sized onion often dividing up and producing as many as twelve onions, from medium size to small sets. The very smallest sets produce from one to two large onions, while the larger sets will produce all the way from two to twenty onions in a hill. A desirable variety both for market and home use and very popular throughout the South. Price: Small. size sets (averaging about the size of a hulled walnut), 15c. per quart; 90 c. per peck; $\$ 3.00$ per bushel. Medium size sets (averaging about the size of an egg), 70c. per peck; $\$ 2.25$ per bushel. Bushel price fluctuates.

WHITE MULTIPLIER. This differs from the Yellow Potato Onion in color, being pure white, and does not make as large onions, but is very productive and of finest flavor, and of slightly better keeping qualities than the Yellow.Potato Onion.

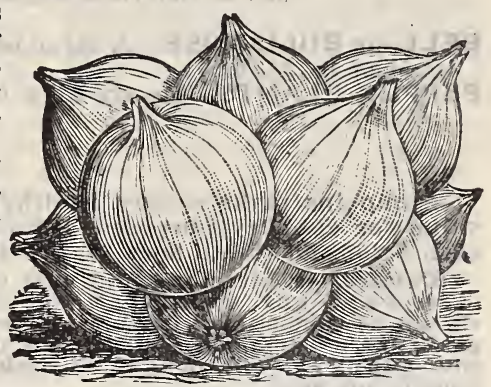

Potato Orions.

YELLOW DANVERS. Qt. $10 \mathrm{c}$.; peck, $60 \mathrm{c}$.; bu. prices on application.

YELLOW DANVERS. Qt. 10c.; peck, 60c.; bushel prices on application.

EXTRA EARLY WHITE PEARL. An extra early variety, producing bulbs of a pure white color, mild and delicate flavor. This sort is for fall planting only. See Fall Catalogue for prices.

\section{PEANUTS-Spanish and Virginia.}

Virginia's noted crop. Plant in May, in drills three feet apart, placing the nuts eight to twelve inches apart in the drill. Cultivate flat and keep clean. It requires 15 to 20 pounds of shelled nuts, or one bushel $(22 \mathrm{lbs}$.) of the peanuts when not shelled to plant an acre. Can be planted either shelled or unshelled. If by mail, add 10c. per quart for postage.

SELECTED VIRGINIA. A fine productive strain, selected especially for seed purposes. Qt. 10c.; peck, 40c.; bu. (22 lbs.), $\$ 1.50$. Special prices in quantity.

SPANISH. This is grown very largely for feeding, the vines or tops making a large yield of excellent and most nutritious hay. If the vines and nuts are pulled up and cured together, it makes one of the richest and most fattening feeds for hogs that can be grown. The nuts are small size, but thin hull and full kernel, and are produced in enormous quantities. Qt. 15c.; peck, 60c.; bu. (30 lbs.), $\$ 2.00$. Special prices on large lots.

CHESTERFIELD CO., VA., March 24, 1902.-The Tood's Earliest Potatoes gave such satisfaction last CHESTERFIELD CO., VA., March 24, 1902
year I would plant no other for early crop.

MRS. HENRY L. GOULD.

SPOTSYLVANIA CO., VA., March 3, 1902.-We have used the Wood's Earliest Potato for several years, and think it the best we ever tried. 


\section{PEPPER,}

Culture.-Sow in hot-bed in February or March, and transplant to open ground in May, in rows two to three feet apart, fifteen inches between the plants; or when the ground becomes warm, sow in oper ground and set out as above. When about six inches high, apply liquid manure or some good fertilizer.

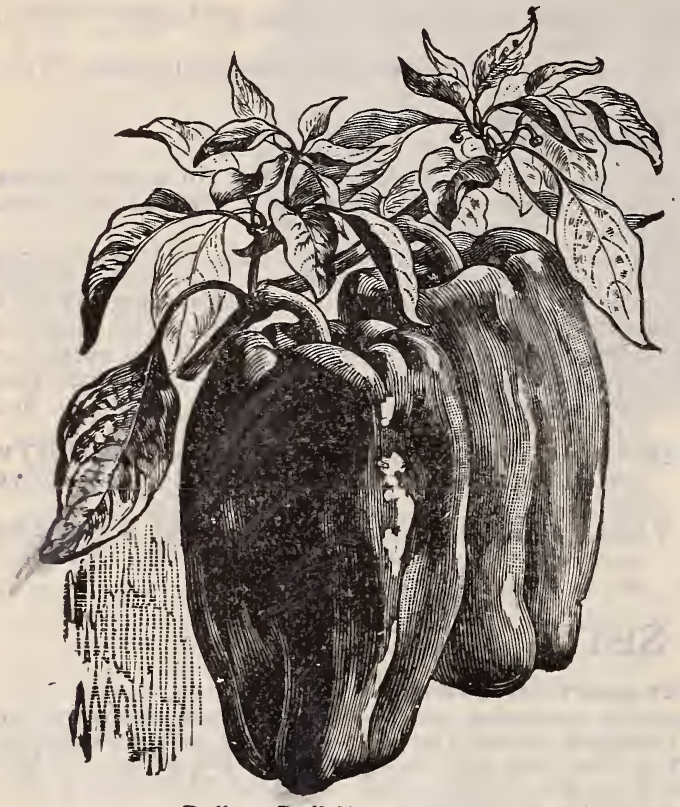

Bell or Bull Nose Pepper.

CORAL GEM BOUQUET. A dwarf pepper, producing hundreds of small, bright red peppers thickly set on the plants. Pkt. 10c.; oz. 35c.; $1 / 4$ lb. $\$ 1.00 ; 1 b . \$ 3.50$.

RUBY KING. These are a bright ruby-red color remarkably mild and pleasant. Can be sliced. and eaten with vinegar and pepper, used as a. salad or stuffed as mangoes. The fruit is from four to six inches long. Pkt. 5c.; oz. $20 \mathrm{c}$; $1 / 4 \mathrm{lb}$. $50 \mathrm{c}$; $1 \mathrm{lb}$. $\$ 1.75$.

LONG RED CAYENNE. Bears an abundance of long, bright red pods, which are used for pickling when both green and ripe. Very strongand pungent. Pkt. 5c.; oz. 20c.; $1 / 1$ lb. 50c.; lb. $\$ 1.75$.

PROCOPP'S GIANT. One of the largest peppers grown, measuring six to eight inches long and about two inches thick. Of a glossy scarlet color; flavor mild and sweet. Pkt. 5c.; oz. 20c.; $1 / 4$ lb. 60 c.; lb. $\$ 2.00$.

MAMMOTH GOLDEN QUEEN. Fruits six inches long by nine to ten in circumference, and are borne twelve to fifteen to each plant. Mild and sweet. Use as described for Ruby King. Pkt. 5c.; Oz. 20c.; 1/4 lb. 60c.; lb. $\$ 2.00$.

TABASCO PEPPER. A very hot and pungent variety; used largely for making pepper sauce. Pkt. 10c.; oz. 50c.

SWEET SPANISH MAMMOTH. Fine for mangoes. Large and of splendid quality. Pkt. $5 \mathrm{c}$.; Oz. 20c.; $1 / 4$ lb. $50 \mathrm{c}$; $1 \mathrm{lb} . \$ 1.60$.

RED CLUSTER. Very hot; color coral red; borne in clusters. Pkt. 5c.; oz. 25c.; 1/1 lb. 70c.; lb. $\$ 2.25$.

BELL, or BULL NOSE. A large early sort, of mild flavor. Color, purplish red. Pkt. 5c.; oz. 20c.; 1/4 Ib. $50 \mathrm{c}$; ; lb. $\$ 1.50$.

PEPPER PLANTS. Ready May and June. Doz. 20c.; 100, \$1.00. See page 3.

\section{PUIMPKIN,}

Pumpkins make a very healthy and nutritious winter feed for hogs and cattle in addition to their value for culinary purposes. Should be grown on every farm. Can be planted to advantage in the corn field, and fed to hogs and cattle during the winter, as desired.

Culture.-Plant in May, in hills eight to ten feet apart, mixing a shovelful or two of well-rotted manure in each hill. Put eight or ten seeds in each hill, and cultivate till the vines get strong, when they should be thinned out, leaving two or three of the strongest plants in each hill. When planted in corn. plant at the same time as the corn, planting in every ourth row of corn, and ten to twelve feet apart in the row, letting the hill of pumpkins take the place of a hill of corn. One ounce will plant twenty hills; three pounds one acre.

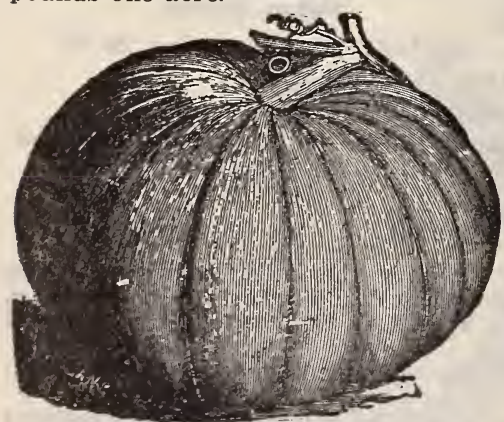

Pumpkin:

VIRGINIA MAMMOTH. The best and most productive variety for the South. Grows to an immense size. Is oval in shape, thick fleshed, of first-rate flavor and splendid keeping qualities. Can be kept all through the winter and fed or used as desired without any trouble. This variety is suited to our climate, and our seed is Southern raised, both of which are very necessary to raise a fine crop of pumpkins. Pkt. 5c.; oz. 10c.; 1/t lb. 30c.; lb. $\$ 1.00$.

CASHAW, or CROOKNECK. One of the best table sorts; also fine for stock feeding. Very productive, and grows to a large size. Pkt. 5c.; oz. 10c.; 1/t 1b. 20c.; lb.60c.

LARGE CHEESE. A fine, large pumpkin of splendid quality. Pkt. 5c.; oz. 10c.; 1/4 lb. 20c.; lb. 50c.

KING OF THE MAMMOTHS, or POT IRON. An immense variety, which has taken several prizes offered for the largest and best pumpkin grown. Single pumpkins have grown to weigh over two hundred pounds. Flesh of a rich golden yellow color; a splendid keeper. Pkt. 5c.; oz. 15c.; 1/4 lb. 35c.; 1b. $\$ 1.25$.

CONNECTICUT, or CORNFIELD. Splendid for stock feeding. Groms to a large size, round, and of a yellow color. A good yielder. Oz. $5 \mathrm{c}$.; $1 / 4$ lb. $10 \mathrm{c}$; ; lb. $35 \mathrm{c}$.; 5 lbs. and over, $30 \mathrm{c}$. $1 \mathrm{~b}$.

CLARKE CO., GA., May 7, 1902.-I have the best garden in town, and I tell every one it is owing to the fact that I use only Wood \& Sons' seed, while they use drug store seed. Your seed tells every time.

NEW HANOVER CO., N. C., May 7, 1902.-All of your seeds have given entire satisfaction. 


\section{ONION.}

Culture.-Large Onions from Seeu.-To grow large onions to best advantage from seed the first year, sow in January or February in hot-beds, and as soon as the weather opens and the sets are the size of a goose-quill, transplant to rows twelve inches apart, and four to six inches between the onions. Transplanting is of decided benefit to onions, making them grow larger, and increasing the yield considerably, in some instances double the yields being reported. They can also be sown in the open ground in February or March, and will make a good crop of medium-sized onions and small onion sets. The medium-sized can be used or sold, and the small onion sets planted out either in the fall or spring to make large onions. The Italian, Spanish and Bermuda varieties can be sown in August or September, and transplanted about the end of October or early in November. They succeed very well indeed. Five or six pounds will sow an acre.

Growing Onion Sets from Seed.-To grow onion sets sow in broad, wide rows, in March or early in April, at the rate of forty to fifty pounds per acre, and keep clean of weeds. In late summer, or whenever the tops die, remove the small bulbs, buttons or sets to a dry place, spreading them out thinly on trays made of laths, piling the trays one on top of another, separated by blocks, so that the air can circulate freely between them. The larger sets should be sold for pickling, and only the smallest sets retained for planting.

LOUISIANA, or CREOLE ONION. A Southern variety of unusual merit. Wherever it is grown it speedily becomes very popular, both with gardeners and truckers. It grows to a large size; color reddish yellow; mild flavor and a splendid keeper. Like the Bermuda onion, it is specially suited to the South. Can be sown either in the spring or fall. When sown in the spring, it should be put in early and transplanted when the size of a goose quill. Pkt. 5c.; oz. 15c. 1/4 1b. $50 \mathrm{c}$; $1 \mathrm{~b} . \$ 1.50$.

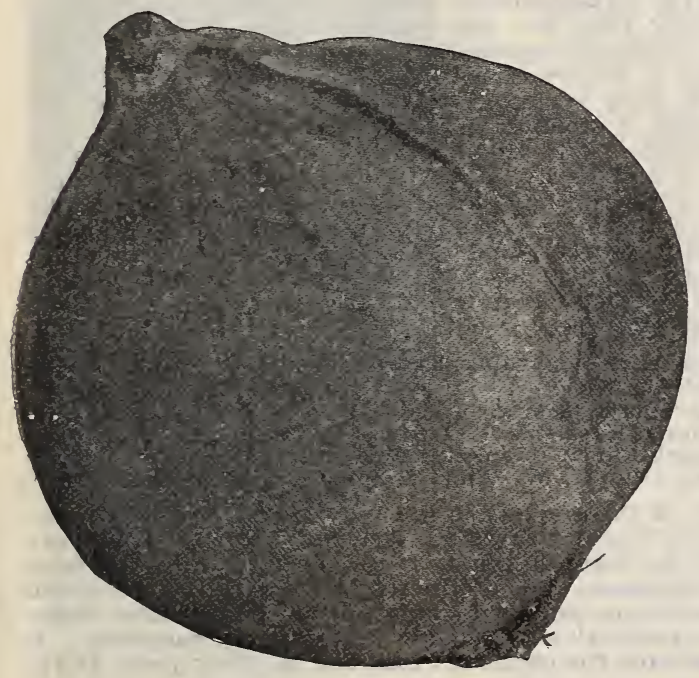

Prize Taker.

EXTRA EARLY RED. Although not large, it is a fine closengrained onion; very early, uniform in size and shape, and a good keeper. Pkt. 5c.; oz. 10c.; $1 / 4$ lb. 30c.; .1b. $\$ 1.00$.

EXTRA EARLY WHITE PEARL. The quickest of the white sorts; makes large pearly. white onions, tender, mild, and of excellent flavor. Should be sown in the spring thickly, and the sets put out in the fall. In this way large onions may be had before any other sorts are ready. Pkt. 5c.; oz. 15c.; 1/1 lb. 50c.; lb. $\$ 1.60$.

SILVER SKIN. Excellent variety for family use. skin and flesh pure white; mild flavor and globe-shape. The best white onion to grow largely for sets. Pkt. 5c.; oz. $20 \mathrm{c}$; $1 / 4$ lb. 60c.; lb. $\$ 1.85$
YELLOW GLOBE DANVERS. Standard variety; globe-shaped, large in size. One of the principal main crop sorts. Keeps well, and is a most desirable market or table onion. Pkt. 5c.; oz. 10c.; $1 / 4$ lb. $25 \mathrm{c}$.; 1b. $90 \mathrm{c}$.

LARGE RED WETHERSFIELD. A very attractive onion, and popular everywhere. Medium early; skin purplish red and flesh :purplish white. Pkt. 5c.; Oz. 10c.; 1/4 lb. 30c.; lb. $\$ 1.00$.

AUSTRALIAN BROWN ONION. A mew, extra early, long-keeping onion, claimed to be the most valuable variety introduced in a generation. Of medium size, wonderfully hard and solid, and will keep longer than any other onion known. It is of very attractive appearance, and makes a very salable and popular variety on our markets. Pkt. 5c.; oz. 10c.; $1 / 4$ db. 25c.; 1 b. $85 \mathrm{c}$.

WHITE QUEEN. A beautiful, small white onion, excellent for pickling. Pkt. 5c.; oz. 15c.; $1 / 4 \mathrm{lb}$. 50c.; lb. $\$ 1.75$.

BERMUDA ONIONS. Our stock of this famous early shipping onion is genuine Teneriffegrown, specially grown for us in the Canary Islands, and is a very superior stock. They are tender and of delicious flavor, and are much appreciated for table use. Can be sown both in the fall and early spring, and do better sown in seed-beds and transplanted. We strongly advise the more extended use of these by our southern growers. We can supply both the White and Red Bermuda. White Bermuda, pkt. 5 c.; oz. 25 c.; $1 / 4$ lb. 65 c.; lb. $\$ 2.25$. Red Bermuda, pkt. 5c.; oz. 20c.; 1/4 lb. 60c.; lb. $\$ 2.00$.

\section{SPANISH AND ITALIAN ONIONS.}

MAMMOTH SILVER KING. This is one of the largest onions in cultivation, growing to a remarkable size. The skin is a beautiful silvery hite, flesh pure white, and of a particularly ild and pleasant flavor. It matures early, and grows uniformly, of large size and perfect form, flattened at the top. Recommended both for fall and spring planting. Pkt. 5c.; oz. 15c.; 1/4 lb. 50 c.; $1 \mathrm{~b}$. $\$ 1.60$

PRIZE TAKER, or SPANISH KING. Like nearly all Spanish onions, this makes extra large size onions and of particularly fine flavor. The outside skin is a rich yellow straw color, and the flesh is pure white, sweet, mild and tender. Ripens up fine and hard, and makes a very handsome and attractive onion. Pkt. 5c.; oz. 15c.; $1 / 4$ lb. 35 c.; lb. $\$ 1.20$.

COPPER KING. This attains an enormous size, single onions having been grown weighing four pounds. The skin is a reddish yellow color, flesh white, very sweet, mild and tender. Pkt, 5c.: oz. $15 \mathrm{c}$.; $1 / 1$ lb. $40 \mathrm{c}$.; lb. $\$ 1.25$. 


\section{GARDEN PEAS.}

Truckers and Gardeners requiring large quantities are requested to write for special prices, stating kinds and quantity wanted.

Early Peas are again a short crop this year, and consequently are higher in price than usual. This should not, however, deter our truckers and market-gardeners from planting their usual quantities, as the general experience is that crops prove most profitable when the seed supply is short and highpriced.

Culture.-Peas succeed best in light, rich, loamy soil, which has been manured the previous season. Plant the smooth varieties in the spring as soon as the ground can be worked, in rows three or four feet apart, two inches deep, giving the taller varieties more room between the rows. For a succession, plant every two weeks. The dwarf varieties can be planted in rows two and a half to three feet apart. Peas grown as a market crop are rarely ever staked,.,but when the taller varieties are grown for private use, it is a good plan to sow them in double rows and stake with brush. They should be kept clean and the earth worked toward them two or three times during growth. One and a half bushel are required to plant one acre; one quart to plant one hundred feet of drill.

Insect Remedies.-Kerosene oil applied with a fine sprayer is highly recommended for the pea-louse.

If to be sent by mail, add for postage at the rate of $8 \mathrm{c}$. per pint, 15c. per quart. Packets mailed free.

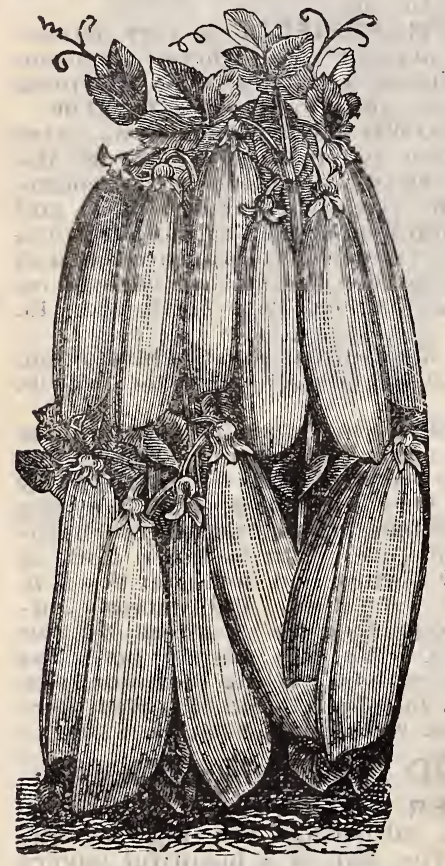

Tom Thumb Peas.

\section{EXTRA EARIY VARIETIES.}

WOOD'S PEDIGREE (Extra Early). A new selection of extra early peas, which is absolutely the earliest, most uniform in ripening, most profitable extra early variety in cultivation. For full description, see "New Seeds of Special Merit," page 4. Pkt. 10c.; qt. 30c.; peck, $\$ 1.75 ;$ bu. $\$ 6.00$.

WOOD'S LIGHTNING EXCELSIOR. This is unquestionably one of the best of extra early peas for the trucker and market-gardener, and it has given unbounded satisfaction to our customers. We are constantly in receipt of letters from them, speaking of the satisfaction and profit from this variety. Until the introduction of our Pedigree Extra Early, it stood at the head of the list as to earliness. It is remarkably prolific. The vines grow two and a half feet high, are strong, vigorous and hardy, standing cold weather better than any other extra early pea we have ever grown. Ripens its crop uniformly, and is one of the most popular peas in cultivation, both for shipping and the home market, and as a first early for home use. Pkt. 5c.; qt. 25c.; peck, $\$ 1.50$; bu. $\$ 5.25$. Special prices on large lots. 'The following are extracts from customers' letters in regard to Wood's Lightning Excelsior Pea:

ARnetr Co., N. C.-Wood's Lightning Excelsior Peas are the earliest, hardiest and best for early market I have ever grown. H. N. BIzzell.

BEAUFORT Co., N. C.- I have been growing early peas for several years, and find Wood's Lightning Excelsior Pea to be the best pea I can get; noted for gathering nearly all at one picking. In fact, I can always rely on any seed that comes from T. W. Wood \& Sons. C. G. MIDYETTE.

ALASKA. Our strain of this variety is the very best. This pea is increasing in popularity every year, and especially in the large peagrowing sections of the Atlantic coast. It is especially valuable, both on account of its earliness and productiveness, and the beautiful green color of its pods and peas, which it retains longer than other varieties, making it particularly valuable for shipping purposes. It is also specially desirable for canners. Pkt. 5c.; qt. 25c.; peck, \$1.35; bu. $\$ 4.75$.

FIRST AND BEST. An excellent strain of first early peas, which is very popular, and largely planted throughout the trucking sections. Pkt. 5 c.; qt. 20 c.; peck, $\$ 1.40$; bu. $\$ 5.00$.

PHILADELPHIA EXTRA EARLY. The old standard extra early sort, coming in a little later than other extra early varieties. It is very popular, and largely planted. Pkt. 5c.; qt. 20c.; peck, $\$ 1.40 ;$ bu. $\$ 5.00$.

TOM THUMB. This is not a wrinkled sort, but is of most excellent table qualities. Grows ten to twelve inches high, is very prolific, and is considered really one of the best dwarf varieties for the private garden. Pkt. 5c.; qt. 25c.; peck, $\$ 1.40$; bu. $\$ 5.00$.

ECLIPSE, or SURPRISE. In the tests on our Hollybrook Farm last year, we were very much impressed with the great value of this variety, as an extra early wrinkled pea. It proved earlier than any of the other wrinkled varieties. The vines do not require staking, grow about two feet high, and are covered with well-filled

pods. The pods are similar to American Wonder in shape and size, but it is more prolific than that variety. Its extreme earliness, great productiveness, delicious quality and height of vine destine this variety to be one of the most popular and desirable sorts for the family garden. Pkt. 5c.; qt. 30c.; peck, $\$ 1.75$.

PROSPERITY, or GRADUS. This pea is a most marked advance and improvement in wrinkled peas, and is the earliest large-podded wrinkled pea in cultivation. It is remarkable for the size and fullness of its pods, yielding an abundant supply of the most delicious large wrinkled peas, which are of most delicious flavor. The vines grow about two feet high, have heavy stems, stand upright, and do not require sticking. The peas remain edible, tender and sweet for some time after they reach their maturity. The Prosperity, or Gradus Pea is considered, altogether, one of the most valuable improvements that have been made in wrinkled peas for a number of years. Pkt. 10c.; pt. 30c.; qt. 50c.; peck, $\$ 3$. 


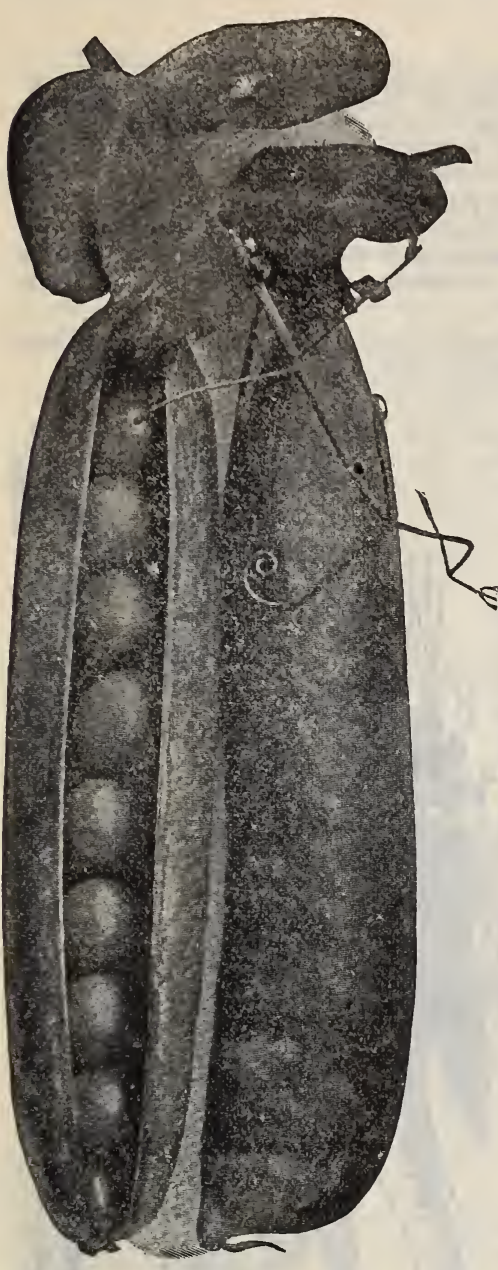

Claudit.

CLAUDIT PEAS. A new large podded extra early wrinkled pea, of the Gradus or Prosperity type. Makes pods equally as large as the Gradus, containing seven or eight large peas of the richest flavor. It has an advantage over the Gradus, however, in that it is several days earlier in maturity. It is pronounced by those who have tested it to be the finest and most remarkable early pea yet introduced. As early as the smooth extra early kinds; pods much larger and more productive. The vines grow two and a half to three feet high. We strongly recommend this new variety, both to private gardeners and truckers, believing it will prove to be one of the best and most satisfactory peas in cultivation. Pkt. 10c.; qt. 40c.; peck, $\$ 2$.

AMERICAN WONDER. One of the earliest of wrinkled peas, and excellent for family use. The vines grow about nine inches high, are of robust nature, and remarkably productive. Pkt. 5 c.; qt. 30 c.; peck, $\$ 1.85$.

MCLEAN'S LITTLE GEM. A favorite early wrinkled variety, maturing a little later than the American Wonder. Of dwar habit, bears abundantly, and is of excellent quality. Height one foot. Pkt. 5c.; qt. 25c.; peck, $\$ 1.60$.

NOTT'S EXCELSIOR. A standard variety of wrinkled peas, coming in a few days later than the American Wonder, but bearing larger pods, and being more prolific than that variety. Vines dwarf in habit, growing about a foot in height; of vigorous constitution and wonderfully productive. Pkt. 5c.; qt. 30c.; peck, $\$ 1.80$.

\section{SECOND EARLY AND LATE VARIETIES.}

BLISS' EVERBEARING. Matures soon after McLean's Gem, and continues a long time in bearing. As the pods are gathered, others mature in succession. Height two feet. Pkt. 5c.; qt. 20c.; peck, $\$ 1.35$.

MCLEAN'S ADVANCER. A very prolific and excellent second early, green, wrinkled variety. pods long and well filled; tender and sweet, and desirable both for the market and home use. Pkt. 5c.; qt. 20c.; peck, $\$ 1.35$; bu. $\$ 4.50$

A LLA N'S D W A F TELE. PHONE. A dwarf variety of the famous Telephone, bearing large, handsome pods of peas of the highest quality, and similar to the tall Telephone, without the long vines of that kind. Very regular and uniform in growth, the vines growing 18 inches high, and are stocky and vigcrous, and healthy, without tendency to sport. Pkt. $10 \mathrm{c}$; ; qt. $35 \mathrm{c}$; ; pk, $\$ 2$.

WOOD'S ACME. A most superior variety for main crop, both for private use and market. The peas are large, wrinkled and of a greenish color. The vines are crowded with pods, and are everbearing to a greater degree than any other pea. Pkt. 5c.; qt. 30c.; peck, $\$ 1.75$.

WOOD'S MAMMOTH LUSCIOUS SUGAR PEA. No edible podded pea we have ever grown can compare with this; when sliced and boiled, served with butter and sauce, they make a most tempting and delicious dish. The pods grow six to seven inches long and an inch and $a$ half broad. Once tried, this will always have a place in the garden. Pkt. $10 \mathrm{c}$.; pt. $30 \mathrm{c}$.; qt. $50 \mathrm{c}$.

TELEPHONE. One of the most productive of the wrinkled peas. Of excellent sugary flavor; pods of large size, containing six or seven peas each. Rather late in maturing, but one of the best for main crop. Height four feet. Pkt. 5c.; qt. 25c.; peck, \$1.50. Bushel price on application.

STRATAGEM. A remarkably fine pea. The vines are almost completely covered with large, well-filled pods. Sweet and delicious. Height two feet. Pkt. 5c.; qt. 25c.; peck, $\$ 1.60$.

CHAMPION OF ENGLAND. Universally admitted to be one of the best late peas grown. Of delicious flavor and a very profuse bearer. Desirable for home use, and especially recommended for market gardeners and for the home market. Very much superior in flavor and table qualities to the Marrowfat Peas. Pkt. 5c.; qt. 20 c.; peck, $\$ 1.20$; bu. $\$ 4.00$.

YORKSHIRE HERO. A superior late pea. The pods are long and well filled; the peas large and of excellent quality. Height, two feet. Pkt. 5c.; qt. 20c.; peck, $\$ 1.35 ;$ bu. $\$ 4.50$.

LARGE WHITE MARROWFAT. Very prolific; largely used for market. Pkt. 5c.; qt. 15c.; pk. 75c.; bu. $\$ 2.60$.

BLACK EYE MARROWFAT. Closely resembles the above, but is considered more prolific. Pkt. 5c.; qt. 15 c.; peck, 75 c.; bu. $\$ 2.60$. 


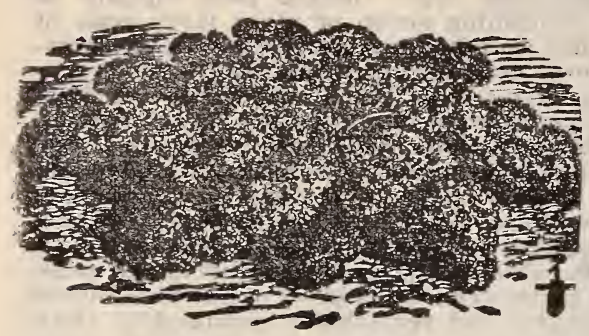

Champlon Moss Curled.

\section{PARSLEY.}

Culture.-Soak the seed in water a few hours, and sow in rich soil early in spring, in rows a foot apart, and cover lightly. Parsley is slow to germinate, and is sometimes three or four weeks in coming up. One ounce will sow one hundred and fifty feet of drill.

CHAMPION MOSS CURLED. The best and most improved strain. It is beautifully curled and crimped, and is the best for garnishing and flavoring. It also makes an ornamental plant for edging walks. Plkt. 5c.; oz. 8c.; $1 / 4$ lb. 15c.; 1b. 45c.

PLAIN, or SINGLE. Very hardy, and stronger in flavor than the curled. Pkt. 5c.; oz. 8c.; $1 / 4$ 1b. 15 c.; $1 \mathrm{~b}, 40 \mathrm{c}$.

\section{PARSNIP.}

Culture.-A rich sandy loam, deeply worked, is the best for parsnips. Sow in the spring, in drills eighteen inches apart, covering lightly. Parsnip seed is very slow in germinating, especially when the ground is dry. When the plants are two inches high thin out to four or six inches apart. One ounce of seed will sow two hundred feet of drill. Five pounds to the acre.

WOOD'S IMPROVED SUGAR PARSNIP. This is a selection and decided improvement over the old Sugar Parsnip, both in shape of roots and flavor. Pkt. 5c.; oz. 10c.; 1/4 lb. 20c.; lb. 50c.

SUGAR, or HOLLOW CROWN. This is an old standard variety. Smooth skin, tender, and well flavored. It is good, either for table use or stock. Pkt. 5c.; oz. 8c.; 1/4 lb. 15c.; 1b. $35 \mathrm{c}$.

PEANUTS, See page 29.

\section{SWEET POTATOES.}

Our seed is grown in Hanover county, Va. This county has a national reputation for producing the finest and best flavored sweet potatoes in this country.

CuIture.-Put the potatoes into hot-beds in April, covering with three inches of earth, and after they begin to grow, give plenty of air on sunny days, and water regularly. In May or June set out in rows three feet apart and fifteen inches apart in the rows. The land should be ploughed shallow in order to produce the short chunky potato most largely in demand. Apply a fertilizer having only a small percentage of nitrogen and a large amount of potash.

EXTRA EARLY CAROLINE. Very early, productive, nearly round shape, of a bright yellow color, and shorter than the ordinary varieties. Peck, $40 \mathrm{c}$; ; bu. $\$ 1.00$. Barrel prices on application.

YELLOW NANSEMOND. The most popular of all yellow sweet potatoes. Peck, 40c.; bu. $\$ 1.00$. Barrel price on application.

RED NOSE. One of the best market varieties; a large yielder, and of good flavor. Bright yellow with tinted red tip, which shows only when freshly dug. Peck, 40c.; bu. \$1.00. Barrel price on application.

HANOVER YAM, or CLUSTER. A large, round, white variety; quite a favorite in some sections. Yields better on heavy soil than the yellow sorts. Peck, $40 \mathrm{c}$; ; bu. $\$ 1.00$. Barrel price on application.

SWEET POTATO PLANTS. Ready May and June. 25c. per $100 ; \$ 2.00$ per 1,000 .

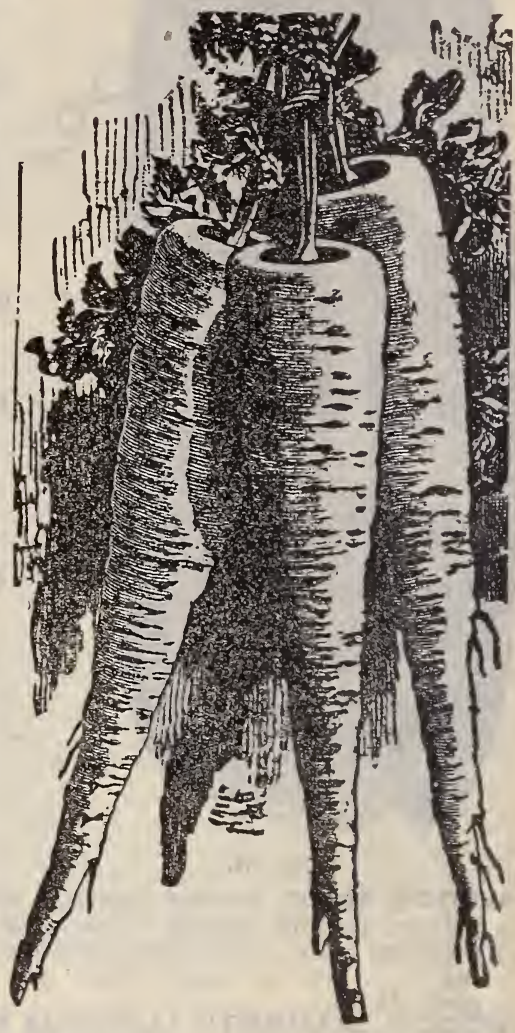

Sugar or Hollow Crown Parsnip.

\section{RHUBARB.}

Culture.-In April sow in drills in a shady or moist situation, and when a few inches high, thin out to twelve inches. The following. fall transplant to a deep, well-manured soil, four feet apart, and protect with manure.or leaves. It may be more quickly grown by setting out the roots either in the spring or fall, covering the crown every fall with coarse manure. Do not gather any the first season, and never allow it to go to seed.

LINNAEUS. The best variety for the South. Pkt. 5c.; oz. 15c.; 1/4 1b. 40c.; 1b. \$1.25.

RHUBARB ROOTS. 10c. each; $\$ 1.00$ dozen. Prices by the 100 on application.

If to be mailed, add 10c. each for postage.

TOBACCO DUST INSECTICIDE. One of the cheapest and most effective remedies TOBACCO DUSI INSECIICIDE. for lice and worms on cabbage, striped bugs and 作

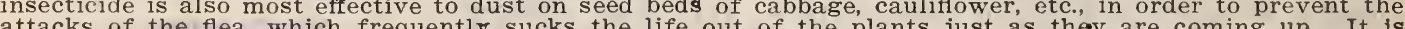
作 also large plants are young. On some crops a few drops of kerosene oil mixed with this insecticide will increase its effectiveness. The tobacco dust also acts as a fertilizer and stimulates the growth of plants, and really makes one of the cheapest and best insecticides in use. Every farmer, gardener and trucker should always have a supply of this insecticide on hand, so as to have it available when needed. Price, 15-1b. package, 25c.; 40 -1b. package, 50c.; 100 lbs. $\$ 1.00 ; 1,000 \mathrm{lbs}, \$ 7.50$. 


\section{RADISH.}

Culture.-To be tender and crisp, Radishes must be grown quickly, and this requires rich soil and plenty of moisture. Commencing with the first mild spell in the spring, sow at intervals of ten days, in a light, rich, deeply dug soil. May also be grown as a catch-crop between rows of beets, lettuce, onions, etc. Radishes can be forced in hot-beds, but must have plenty of ventilation and moisture. For fall and winter use, sow the China Winter or Spanish varieties in August or September. One ounce will sow fifty feet; eight to ten pounds one acre.

\section{TURNIP_SHAPED VARIETIES.}

EXTRA EARLY SCARLET, or CARDINAL GLOBE. One of the earliest radishes grown, and one of the best for forcing. Makes a very small top, of bright red color, and is very attractive, both in color and shape, making it a good seller. Mild, crisp, juicy, and tender. Pkt. 5c.; oz. $10 \mathrm{c} . ; 1 / 4$ lb. $20 \mathrm{c} . ;$ lb. $50 \mathrm{c}$.

EARLY WHITE TIPPED SCARLET. A beautiful radish, coming in very early; tops very small, permitting of close planting; quality excellent. Pkt. 5c.; oz. 8c.; 1/4 lb. 15c.; lb. 40c.

EARLY RED, or SCARLET TURNIP. A small round radish with small tops and of quick growth. Desirable for forcing or early out-door planting. Crisp and tender. Pkt. 5c.; oz. 8c.; $1 / 4$ lb. $15 \mathrm{c}$.; lb. $40 \mathrm{c}$.

EARLY WHITE TURNIP. A rapid grower; skin and flesh pure white. Good for both forcing and general garden culture. Pkt. 5c.; oz. 8c.; $1 / 4$ Ib. 15c.; lb. 40c.

MIXED TURNIP RADISHES. A mixture of all the above varieties. Pkt. 5c.; oz. 8c.; $1 / 4$ lb. 15c.; lb. $40 \mathrm{c}$.

GOLDEN GLOBE SUMMER. Grows to a large size, and as it stands heat well, may be sown quite late. Crisp and tender. Pkt. 5c.; oz. 8c.; $1 / 4$ lb. $15 \mathrm{c}$; 1 1b. $45 \mathrm{c}$.

\section{OLIVE-SHAPED VARIETIES.}

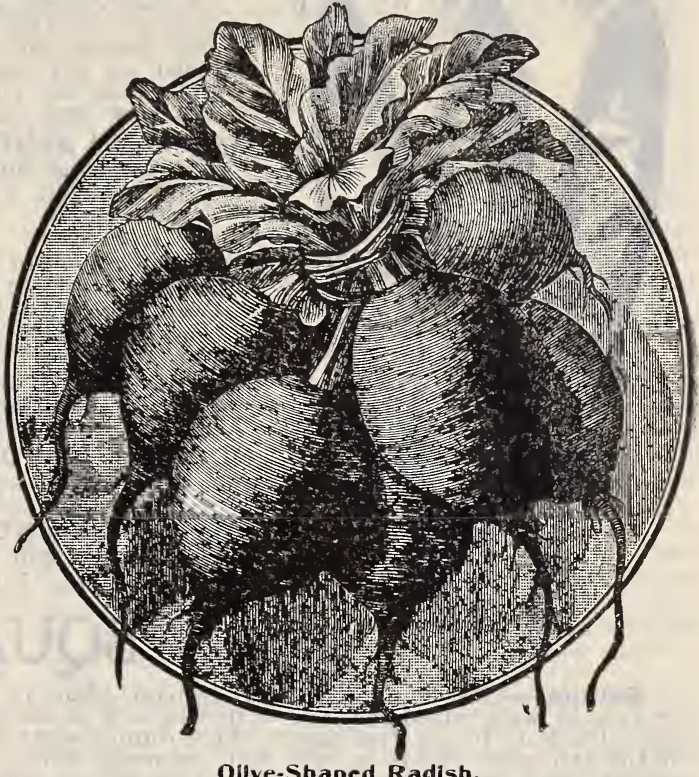

EXTRA EARLY SCARLET OLIVE-SHAPED. One of the best of early radishes, very popular with truckers and for the family garden. Oblong in shape; of a deep scarlet color, quick growing, crisp, and of excellent table qualities. Pkt. 5c.; oz. 8c.; 1/4 lb. 15c.; lb. $35 \mathrm{c}$.

FRENCH BREAKFAST. Of quick growth; crisp and tender. Color, scarlet, except at tip, where it is pure white. Pkt. 5c.; oz. 8 c.; 1/4 lb. 15c.; 1b. $45 \mathrm{c}$.

YELLOW OLIVE-SHAPED. Equally well adapted for forcing as for summer use. Of rapid growth and fine quality; tender, crisp and brittle. Pkt. 5c.; oz. 8c.; 1/4 lb. 15c.; lb. 45c.

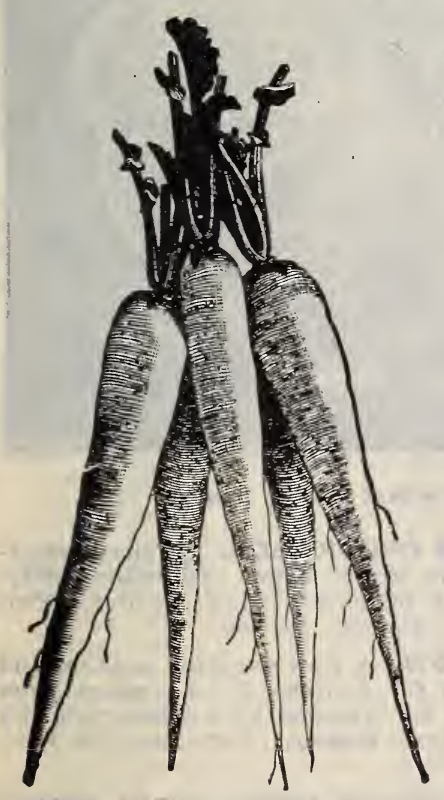

Long White Naples.

\section{LONG VARIETIES.}

CHINESE, or CELESTIAL RADISH. A quick growing white variety, very tender and agreeable in flavor. Shape half long, stump-rooted. A variety of unusual merit, and can be sown either in the spring or fall. Retains its crispness and flavor longer than other sorts. Highly recommended. Pkt. 5c.; oz. 10c.; 1/4 lb. 20c.; lb. 60c.

LONG WHITE NAPLES. A very excellent sort, much better in every way than Long White Vienna and Lady Finger. Skin white; flesh fine grained, crisp, good flavor. Pkt. 5c.; oz. 8c.; 1/4 lb. 15c.; lb. 40c

BRIGHTEST LONG SCARLET. A decided improvement in earliness and color over other varieties of its class. Fit for use in about twenty-five days, when planted out-doors; has a small top, and no neck; bright scarlet color. Pkt. 5c.; oz. 8c.; 1/4 lb. 15c.; lb. 40c.

WOOD'S EARLY FRAME. One of the earliest radishes grown, its small top making it very fine for forcing; shorter and thicker than the Long Scarlet and earlier. Tender, crisp and fine flavored. Pkt. 5 c.; oz. 8c.; 1/4 lb. 15c.; lb. $40 \mathrm{c}$.

CHARTIER LONG SCARLET. A beautiful long radish, of a deep crimson color shading to white at the tip. Splendid for out-door culture. Will keep tender longer than any other variety. Pkt. 5c.; oz. 8c.; $1 / 4$ 1b. $15 \mathrm{c}$.; 1b. 40c.

MIXED LONG RADISHES. A mixture of the above fcur long radishes. Pkt. 5c.; oz. 8c.; $1 / 4$ lb. 15c.; lb. $40 \mathrm{c}$.

\section{WINTER VARIETIES.}

ROSE CHINA WINTER. Roots cylindrical; color, bright rose; flesh white and of superior quality. One of the best. Pkt. 5c.; oz. 8c.; $1 / 4$ lb. $15 \mathrm{c} . ; 1 \mathrm{~b} .40 \mathrm{c}$.

LONG BLACK SPANISH. One of the latest and hardiest of radishes. Oblong in shape, of large size. Pkt. 5c.; oz. 8c.; 1/4 lb. 15c.; lb. 35c.

LONG WHITE SPANISH. Flesh white, firm and pungent, but milder than the Black Spanish. Grows six to eight inches long. Pkt. 5c.; oz. 8c.; $1 / 4$ lb. $15 \mathrm{c}$; $1 \mathrm{lb} .35 \mathrm{c}$. 


\section{SALSIFY, OR OYSTER PLANT.}

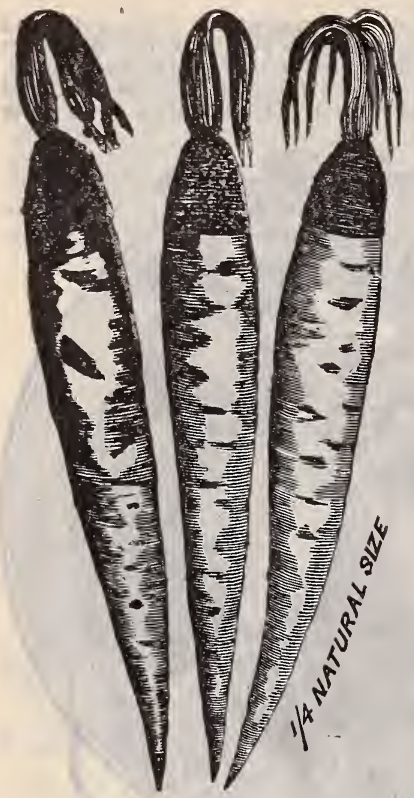

One of the best and most popular winter vegetables. Boil and serve in sauce, or when made into fritters, the flavor is quite similar to fried oysters.

Culture.-Sow in March or April in a rich, light, deeply-worked soil, in rows eighteen inches apart, and thin out to four or six inches. Do not use course or fresh manure, it will make the roots ill-shaped and uneven. Cultivate often to keep down weeds. It is perfectly hardy, and may remain out all winter. Can also be sown in May and June provided we get seasonable weather, or boards be used to get the seed up, and shade the young sprouts until they get well established. One ounce will sow fifty feet of drill; eight pounds one acre.

MAMMOTH SANDWICH ISLAND. A great improvement over the old sort, growing double the size. Quality excellent. Pkt. 5c.; oz. 10c.; $1 / 4$ lb. 30 c.; lb. $\$ 1.00$.

\section{SPINACH.}

Culture.-For early summer use, sow early in spring in a good, wellfertilized soil, in drills one inch deep, eighteen inches to two feet between the rows. For winter and spring use, sow in September and October. Requires but little cultivation. One ounce will sow one hundred feet of drill; twenty pounds one acre.

ROUND THICK LEAVED. The best variety for spring seeding; makes thick, dark green, crimpled leaves of finest quality. Oz. $5 \mathrm{c}$.; $1 / 4 \mathrm{lb}$. $10 \mathrm{c}$; $1 \mathrm{~b}$. 20c.; $5 \mathrm{lbs}$. and over, 17c. per $\mathrm{lb}$.

NORFOLK SAVOY, or BLOOMSDALE. Very early and hardy, with leaves curled and wrinkled like a Savoy cabbage. Best for fall sowing. Oz. 5c.; 1/4 lb. 10c.; 1b. 20c.; 5 lbs. and over, 17c. per lb.

LONG STANDING. Fine for both fall and spring sowing. Leaves thick and fleshy; will stand long without running to seed. Oz. 5c.; $1 / 4 \mathrm{lb}$. 10c.; lb. 20c.; 5 lbs. and over, $17 \mathrm{c}$. per $1 \mathrm{~b}$.

\section{SQUASH, OR CYMLING.}

Culture.-After danger of frost is past, plant in a warm, well-pulverized, rich soil, mixing a shovelful or two of well-rotted manure with the soil in each hill. Plant eight or ten seeds to the hill, the bush varieties four to six feet apart, the running sorts eight to ten. When well grown, thin out; leaving three of the strongest plants in each hill. Summer sorts, o ne ounce to forty hills, four to six pounds to an acre; winter sorts, one ounce to ten hills, four to five pounds to an acre.

WOOD'S EARLIEST PROLIFIC. A most valuable extra early variety, a week to ten days earlier than the Early White Bush; is of similar growth and shape, except that the scallops are not as decided, being more evenly rounded on the edge; the color is a creamy white. The vines are of true bush form, about two feet high, and of vigorous growth; very prolific, and a most profitable and satisfactory sort, particularly for truckers and market gardeners, as its earliness enables it to be sold at much better prices than when the later sorts are ready. Pkt. 5c.; oz. 10 c.; 1/4 lb. 25c.; lb. 80 c.

EARLY WHITE BUSH, Or PATTY PAN CYM. LING. For many years this has been extensively grown in the South for shipment to Northern and nearby markets, also for home use. It is early, of a light cream color, very prolific, grows to a nice size, and is an excellent shipper. Pkt. 5c.; oz. 10c.; 1/4 lb. 20c.; 1b. $65 \mathrm{c}$.

MAMMOTH WHITE BUSH. Quite similar to the Early White Bush from which it was originally selected. It differs in being larger and more uniform in shape; color a beautiful waxy white. Pkt. 5c.; oz. 10c.; 1/4 1b. $20 \mathrm{c}$.; lb. $65 \mathrm{c}$.

WOOD'S EVERBEARING SQUASH. The great value of this new squash is in its enormous productiveness and continuous bearing qualities. Planted early in the season, it will continue bearing all summer. In shape it is like the Early White Bush. Color, white, but some few of the squashes will have green stripes. It sets its fruit moderately early, and makes vines ten or fifteen feet long. It is best to pick the fruit as soon as it matures, before it gets hard, as in this way it will keep up its enormous yielding qualities until the end of the summer. It makes an excellent table squash, and is also very valuable to grow for feeding to cattle and pigs. Pkt. 5c.; oz. 10c.; 1/4 lb. $25 \mathrm{c}$.; lb. $75 \mathrm{c}$.

GOLDEN SUMMER CROOKNECK. One of the best summer sorts; early, prolific, of a bright yellow color, profusely warted, and of the best flavor. Pkt. $5 \mathrm{c} . ;$ oz. $10 \mathrm{c} . ; 1 / 4$ lb. $20 \mathrm{c}$; 1b. $65 \mathrm{c}$.

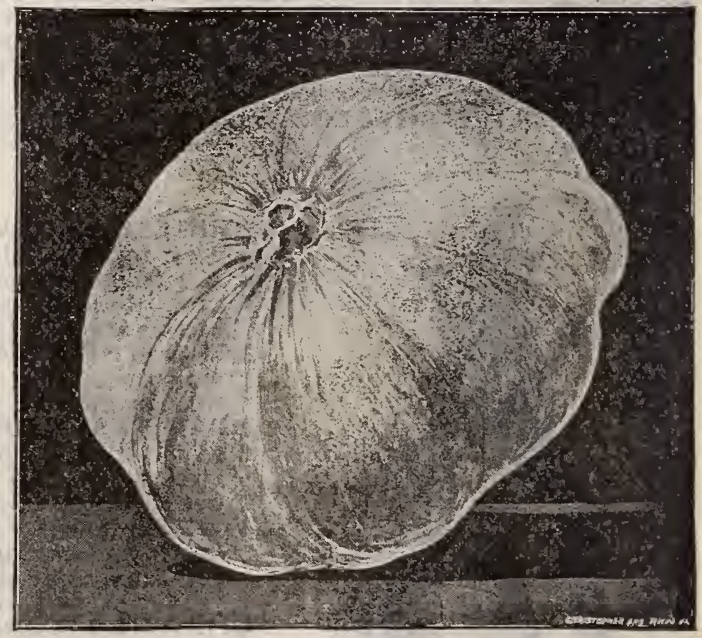

Wood's Earliest Profific Squash.

GIANT SUMMER CROOKNECK. In shape similar to above, but much larger and more warty. Also claimed to be several days earlier. Pkt. 5c.; oz. 10c.; 1/4 1b. 20 c.; 1b. 65 c.

BOSTON MARROW. A very superior squash, and one of the best for winter. Oval shaped, flesh orange colored, fine grained, and cooks rich and dry. An excellent keeper. Pkt. 5c.; oz. 10c.; $1 / 4$ lb. $25 \mathrm{c}$.; 1b. $75 \mathrm{c}$.

HUBBARD. A splendid keeping winter squash, with bright orange flesh, fine grained, very dry, sweet, and rich flavored. Pkt. 5c.; oz. 10c.; 1/4 lb. 30 c.; 1b. $\$ 1.00$. 


\section{TOMATO.}

Culture. - Sow in a hot-bed in early spring, or the seed may be sown in shallow boxes and transplanted to the open ground when all danger of frost is past, setting the plants three or four feet apart each way. Some support should be provided for the vines, to keep the fruit from the ground. Fruit may be had several weeks earlier by sowing seed quite early, and transplanting to small pots. When these are filled with roots, shift to a larger size, and transplant to open ground when the weather is warm and settled, shading from the sun for a day or so. As the roots are not disturbed in taking plants from the pots, the plants suffer no check, but grow right on

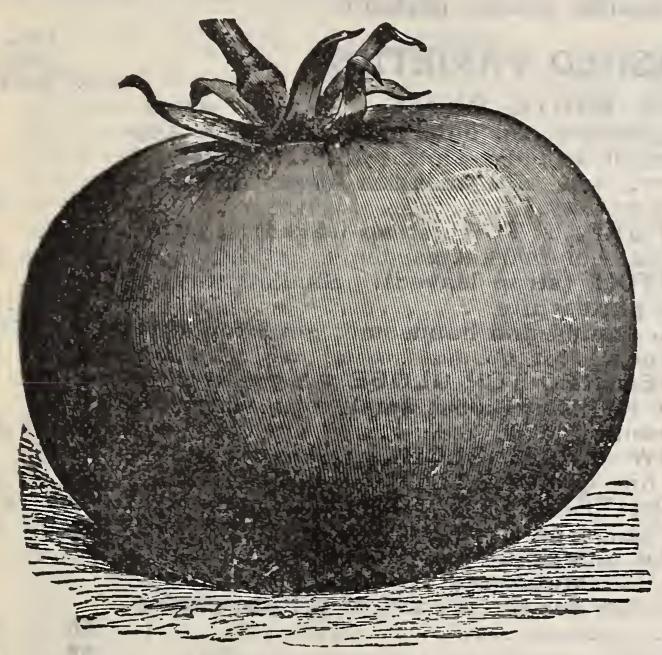

Success Tomato.

SPARKS' EARLIANA. A new introduction which has unquestionably proved itself to be the earliest large Tomato in cultivation. For full description see "Seeds of Special Merit," page 5 . Pkt. 10c.; oz. 60c.; 1/4 lb. $\$ 2.00$; lb. $\$ 7.50$

WOOD'S FIRST EARLY. Valuable for its extreme earliness, coming in ten days to two weeks ahead of any other sort. The fruits are smooth, round, purplish red color, uniform in size and shape, making most desirable and salable fruits; medium in size, and a most prolific yielder. Pkt. $10 \mathrm{c}$; oz. $40 \mathrm{c}$; $1 / 4$ lb. $\$ 1.00 ; \mathrm{lb}$. $\$ 3.50$.

SUCCESS TOMATO. A new variety of decided merit, produces beautiful scarlet fruits of the finest quality, handsome appearance, large size, and is enormously productive. The vines are of strong, vigorous growth, with abundant foliage. Fruit perfectly smooth and free from cracks. The interior is unusually meaty and it ripens evenly throughout. Makes uniformly large sized tomatoes, which, with its handsome color and great solidity, make it a most excellent sort. It is very well adapted both for private use and for market, while its unusual solidity of flesh and desirable form for rapid peeling make it a particularly desirable sort for canners. It is also a fine flavored tomato, either raw or cooked, and we feel sure will prove to be one of the most popular tomatoes offered for sale. Pkt. 10c.; oz. 40c.; 1/1 lb. $\$ 1.00$; lb. $\$ 3.50$

MATCHLESS. One of the best main crop tomatoes. The solidity, absence of core, size and color of the fruit, together with its freedom from rot, all unite in making this well worthy of the name of "MIatchless." Fine both for private and market garden and canning. Pkt. $5 \mathrm{c}$; oz. $25 \mathrm{c}$; $1 / 4$ lb. $75 \mathrm{c}$; ; lb. $\$ 2.75$.

PONDEROSA. A most desirable sort for the private garden or home use, makes fruits of the largest size, flesh remarkably solid, contains very few seeds, and in flavor and table qualities has no superior. Pkt. $10 \mathrm{c}$; oz. $40 \mathrm{c} . ; 1 / 4$ lb. $\$ 1.00$. lb. $\$ 3.50$.

CRIMSON CUSHION. A very large tomato of the Ponderosa type, but more symmetrical in shape, and thicker through from stem to blossom end. Color brilliant scarlet; flesh solid, and has but few seeds. One of the best very large or beef steak varieties. Pkt. 5c.; oz. 25c.; $1 / 4$ 1b. $80 \mathrm{c} . ; 1 \mathrm{~b} . \$ 3.00$

THE STONE. This is deservedly one of the most popular tomatoes in our list for shipping, canning and the home market. Of large size, bright scarlet color, and withstands rot and blight better than any other sort. It makes most attractive and salable fruits, firm and uniform, and is an excellent shipper. Pkt. 5c.; oz. $15 \mathrm{c} . ; 1 / 4$ lb. $50 \mathrm{c}$; $1 \mathrm{lb}$. $\$ 1.75$.

BEAUTY (Improved). We recommend this variety very strongly. It is one of the very best and most productive main crop tomatoes. Makes large sized fruits, color glossy purplish crimson, is uniformly round and smooth, a good shipper and most desirable market and table variety. Pkt. 5c.; oz. 15c.; 1/1 lb. 50c.; lb. $\$ 1.85$.

ACME. Popular everywhere. Very early, smooth, solid and makes a perfect shipper. Color, purplish; ripens all over and through at the same time, and bears till frost. Pkt. 5c.; oz. 15c.; $1 / 4$ lb. $50 \mathrm{c}$; ; $1 \mathrm{~b}$. $\$ 1.75$.

IMPERIAL. A splendid purplish red sort, perfectly smooth, very solid, and has very few seeds. It ripens evenly to the stem, is a strong grower, and is not subject to crack or blight. Although very early, it continues to bear large fruits till frost. Pkt. 5c.; oz. 20c.; 1/4 lb. 60c.; lb. $\$ 2.00$.

PERFECTION. Early, of bright red color, perfectly smooth, ripens uniformly, and bears abundantly till frost. Fine for canning. Pkt. 5c.: oz. 15 c.; $1 / 4$ lb. 50c.; lb. $\$ 1.75$.

FAVORITE. Very prolific, solid, of a dark red color, and ripens early and evenly. A good sort for all purposes. Pkt. 5c.; oz. 15c.; $1 / \pm 1 \mathrm{lb}$. $45 \mathrm{c}$; lb. $\$ 1.75$.

PARAGON. Smooth as an apple, good size, solid, and a good bearer. Fine for family, market, or canning. Pkt. 5c.; oz. $15 \mathrm{c}$.; 1/1 lb. 50c.; lb. $\$ 1.75$.

IMPROVED TROPHY. The oid popular variety, much improved. A standard for size, smoothness, and solidity. Pkt. 5c.; oz. 20c.; 1/4 1b. 60c.; lb. $\$ 1.90$.

DWARF CHAMPION. A dwarf-growing variety, stiff and upright, being self-supporting even when laden with fruit. Can be grown as close together as three feet. Early and prolific. Pkt. 5c.; oz. $25 \mathrm{c}$; $1 / 1$ 1b. 80c.; lb. $\$ 3.00$

GOLDEN QUEEN, or YELLOW TROPHY. IIakes large. handsome, smooth tomatoes of finest quality. One of the best of the yellow sorts. Pkt. 5c.; oz. 15c.; 1/4 lb. 50c.; lb. $\$ 1.75$.

YELLOW' PLUM. Fine for preserving and pickling. A good yielder. Pkt. 5c.; oz. 15c.; $1 / 4$ lb. $50 \mathrm{c}$.; lb. $\$ 1.75$.

TOMATO PLANTS. May and June. Matchless, Beauty, Acme, Perfection, Trophy, and Yellow Plum. Hot-bed plants, dozen, 10c.; 100, 35c. $1,000, \$ 3,00$. Transplanted plants, dozen, $15 \mathrm{c}$; $100,75 \mathrm{c} . ; 1,000, \$ 6.00$. 


\section{WOOD’S TURNIP AND RUTA BAGA SEEDS.}

Culture.-Sow the early sorts in July or August, the later sorts during August, and the salad varieties during August and September. Sow either broadcast or in drills two feet apart, thinning out to six inches, and roll the ground after sowing. Ruta. Bagas should be sown in July and early in August, and inches, and roll the ground after sowing. Ruta Bagas should be sown in July and early in August, and to the acre in drills, two pounds broadcast; salad turnips require three pounds per acre.

Price, 5c. per oz., 15c. per quarter pound, postpaid-all varieties, except Milans, which are 5c. per pkt. 10c. per oz., 20c. per quarter pound, postpaid.

WHITE-FLESHED VARIETIES.

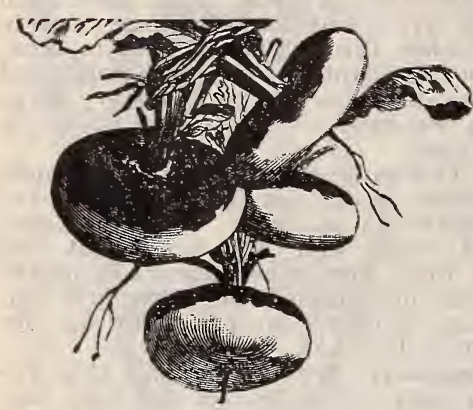

Purple Top Milan.

NEW STRAPLEAF WHITE GLOBE. A new, quickgrowing turnip, similar to our Improved Red Top Globe, except that it is pure white. It is of excellent quality and flavor, and will make a most desirable

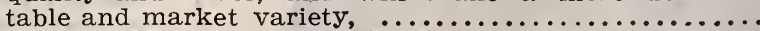

EARLY RED, or PURPLE TOP (strap-leaved). Early, desirable for private or market garden, ...................... WHITE FLAT DUTCH (strap-leaved). Similar to Red

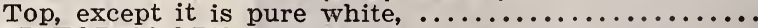

RED TOP GLOBE. Round and handsome; good for market, garden or stock, $\ldots \ldots \ldots \ldots \ldots \ldots \ldots \ldots \ldots \ldots \ldots \ldots \ldots \ldots \ldots \ldots \ldots$ WOOD'S IMPROVED RED TOP GLOBE. A greatly improved strain of Red Top Globe; small tops, very uniform and hand some roots, $\ldots \ldots \ldots \ldots \ldots \ldots \ldots \ldots$.

SOUTHERN SNOW WHITE GLOBE. A An early round white variety of fine quality. Table or stock, ......... POMERANIAN WHITE GLOBE. A popular main crop

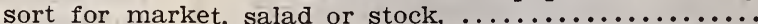

MILAN TURNIPS. In flavor and table qualities the Milans unquestionably surpass any variety we have ever grown. Also remarkable for their quickness of growth, and are especially recommended as the best early turnips either for the market or private garden.

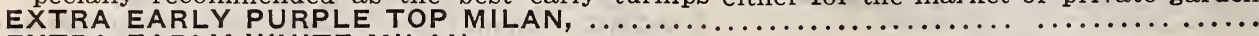

EXTRA EARLY WHITE MILAN,

LARGE WHITE NORFOLK. Largely grown for sto

LARGE WHITE HANOVER. A splendid second early white sort for stock or market,...

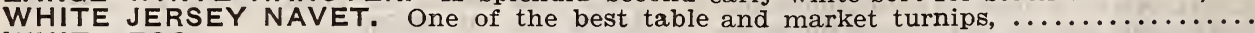

WHITE EGG. A pure white, rapid-growing, egg-shaped sort, $\ldots \ldots \ldots \ldots \ldots \ldots \ldots \ldots$

5 lbs. \& over. Per lb. Per ib

LONG WHITE COWHORN. An excellent white table or stock-feeding sort, .........45

\section{SALAD VARIETIES.}

SOUTHERN PRIZE. Fine for stock or winter salad; hardy, and needs no protection. .................................. SEVEN' TOP. Grown only for winter salad. Very hardy,

\section{YELLOW-FLESHED VARIETIES.}

PURPLE TOP YELLOW ABERDEEN. A splendid stock-

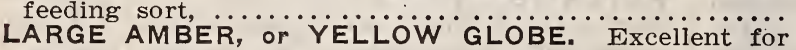

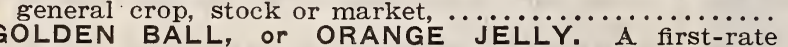

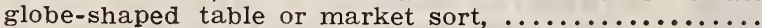

\section{RUTA BAGA OR SWEDES.}

PURPLE TOP YELLOW RUTA BAGA. Largely grown

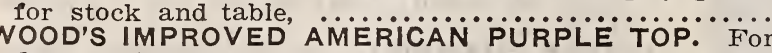
fine qualities and productiveness this cannot be too highly recommended. The roots are finer and larger than the ordinary strains; the flesh is rich and sweet. Whether for table use or stock, it has no superior, ....

WHITE SWEETGERMAN. A globe-shaped variety of good quality for table or stock, $\ldots \ldots \ldots \ldots \ldots \ldots \ldots \ldots \ldots$
BREADSTONE, or BUDLONG. Handsome medium sized ARGE WHITE, or RUSisiaï. A A white-fleshed variety

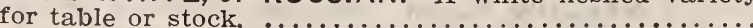
If ordered to be sent by mail, add eight cents per pound for postage.

OUR FALL CATALOGUE, issued in August, gives the fullest information about also about Vetches, Crimson Clover, Seed Wheat, Oats, Rye, Barley, etc. vegetable seeds for fall sowing, free upon request.

IREDELL CC., N. C.- I have used your seeds for several years, and prefer them to all others. MRS. JAMES M. WHAREY. 


\section{WOOD'S HIGH GRADE TOBACCO SEEDS.}

Tobacco seed is one of our leading specialties, and we sell it in the largest quantities, and have built up quite a reputation for the superior quality of our seeds. We also supply the same in large quantities for export to other countries, and our trade in this particular line is of considerable importance. While Virginia is noted for producing the finest tobacco in the world, still there are some varieties which succeed better in other sections. Where this is the case, we have had seed of these particular varieties specially grown for us in the section where the varieties do best, so as to supply our customers with the very best strains of seed that it is possible to obtain.

\section{CIGAR VARIETIES.}

FLORIDA SUMATRA. This variety makes the highest grade of cigar wrapper tobaccos, and brings a very high price in our markets. It has been very profitably grown in Connecticut, Florida, Texas and some other States, and we recommend tobacco growers to experiment with this variety in other sections. Our seed is grown specially for us, by one of the largest American growers, and is of a most superior type. Pkt. 10c.; oz. 40c.; 1/t lb. $\$ 1.00 ; 1 b . \$ 3.50$.

OHIO ZIMMER SPANISH. Our seed of this is grown specially for us in the Miami Valley, Ohio, where this variety succeeds to the greatest perfection, and with the most profitable results. It makes one of the best and most desirable cigar tobaccos grown in this country. Pkt. 10c.; oz. 40c.; $1 / 4$ lb. $\$ 1.00$; lb. $\$ 3.00$.

VUELTA DE ABAJO. The finest, silkiest and highest flavored Havana tobacco grown. To produce it to perfection the land must be rich and comparatively fresh. It succeeds best on the chocolate soils of Florida and Texas. Fine crops are also grown on reclaimed swamps or hummock lands throughout the South. First crop from imported seed, pkt. 15c.; oz. 50c.

IMPORTED HAVANA. The finest Cuban stock. Pkt. 20c.; oz. 60c.

CHOICE HAVANA. An Americanized Havana, used for cigar purposes, although sometimes used as a manufacturing sort. Has a very large, long leaf, makes a fine quality leaf, very early, making two crops a season in some sections. Best adapted to chocolate or rich gray soils. Pht. 10c.; oz. 25c.; 1/4 lb. 85c.; lb. $\$ 2.50$.

CONNECTICUT SEED LEAF, Our seed is Connecticut-grown. A stocky plant; leaves not so long, but of good width; suitable for cigar fillers. The alluvial valley of the Connecticut is best suited to this, but it is grown all over the United States. Pkt. 5c.; oz. 20c.; 1/4 lb. 60c. lb. $\$ 2.00$.

COMSTOCK SPANISH. A variety of great value in the West; used in Ohio, Maryland, and New York State for cigar fillers and wrappers; also in the extreme West, Wisconsin, etc. It does best on good, rich chocolate soils. Pkt. 10c. oz. $40 \mathrm{c}$.; $1 / 4$ lb. $\$ 1.00 ; 1 \mathrm{~b} . \$ 3.00$.

\section{SELECT VARIETIES.}

Price: Pkt. 10c.; oz. 25c.; 1/t lb. 75 c.; lb. $\$ 2.50$, postage paid.

IMPROVED YELLOW ORONOKO. For yellow wrappers, cutters and smokers. Cures easily a bright color, or can be cured for dark filler. It has good width and fine length of leaf. Does best on light gray soil overlying yellow clay.

IMPROVED HESTER. A variety adapted for wrappers, cutters, fillers or cigars. It has a fairly long leaf of medium width, and cures bright. Adapts itself over a wider range of soils and climates than any other variety. Is best adapted to gray or sandy soils overlying yellow ciay, or to chocolate soils.

IMPROVED LONG LEAF GOOCH. For cutters and wrappers. Has a long, tapering leaf of fine texture, and makes fine bright tobacco. Succeers best in eastern Caroina, and it does best on light or sandy soils.
WHITE BURLEY. Seed grown specially for us in the White Burley district of Kentucky. The best filler tobacco known, on account of its absorbing qualities. Has a long, wide leaf, very porous; makes bright reds, and is fine for plug fillers and wrappers. It is best adapted to limestone soil.

KENTUCKY YELLOW. A very fine, large, broadleaved tobacco, suitable for strips, dark wrappers and fillers, making a dark tobacco. It is best suited to chocolate, alluvial, and rich red clay soils, producing heavier yields to the acre than any other sort.

RAGLAND'S CONQUEROR. One of the best bright tobaccos for wrappers and cutters. Of a beautiful oval shape, and makes the finest bright. Best suited to gray or sandy soils overlying yellow clay.

\section{STANDARD VARIETIES.}

Price: Pkt. 5 c.; oz. 20 c.; $1 / 4$ lb. 60 c.; lb. $\$ 2.00$, post age paid.

ONE SUCKER. A dark manufacturing sort, of fairly good breadth, long leaf, and good, rich quality. It is claimed that this grows fewer suckers than other variety. Best suited to alluvial, chocolate, and rich red clay soils.

BIG ORONOKO. A very large and heavy variety for fillers and strips. Makes a wide, long lea of dark color. Best adapted to rich alluvial and red clay soils.

SWEET, or LITTLE ORONOKO. Makes the finest fillers known. Cures a rich red, long and narrow leaf, tough and waxy. It is best adapted to rich red and gray lands.

IMPROVED WHITE STEM ORONOKO. Fine for wrappers, cutters and smokers. Makes a bright leaf of good width and length. Best adapted to a light gray or sandy soil.

BLUE PRYOR. A large, long and broad leaf. Makes a rich, waxy tobacco for black wrappers, strips, and fillers; best adapted for rich lots and alluvial soils.

YELLOW PRYOR. A good general purpose tobacco. Makes a fine wrapper, cutter, filler or smoker, and if put on rich red tobacco land will make almost as dark and heavy as Blue Pryor, also well adapted to a good gray land with red subsoil.

MEDLEY PRYOR. Not as large as the Blue Pryor, but is a very rich, heavy tobacco, and suitable for the same soil and purposes.

GOLD LEAF. A bright sort for plug wrappers, cutters and fillers. Has more body than Gooch, not so large as that variety, but of good texture. Best suited to gray and sandy soils.

STERLING. A fine silky bright tobacco. Makes fine long wrappers and smokers, and one of the finest for these purposes, but of rather too much body for cutters. Best adapted to a gray and yellow subsoil.

BEAT ALL, or Lacks. A heavy, dark type, and makes a splendid mahogany. Large, long, and of good texture for dark wrappers and fillers. Best suited to a gray soil with red subsoil, or to red clay lands.

BROAD LEAF GOOCH. A heavier sort than Long Leaf Gooch. Makes good mahogany wrappers, as well as bright grades. Best suited to gray or sandy soil. 


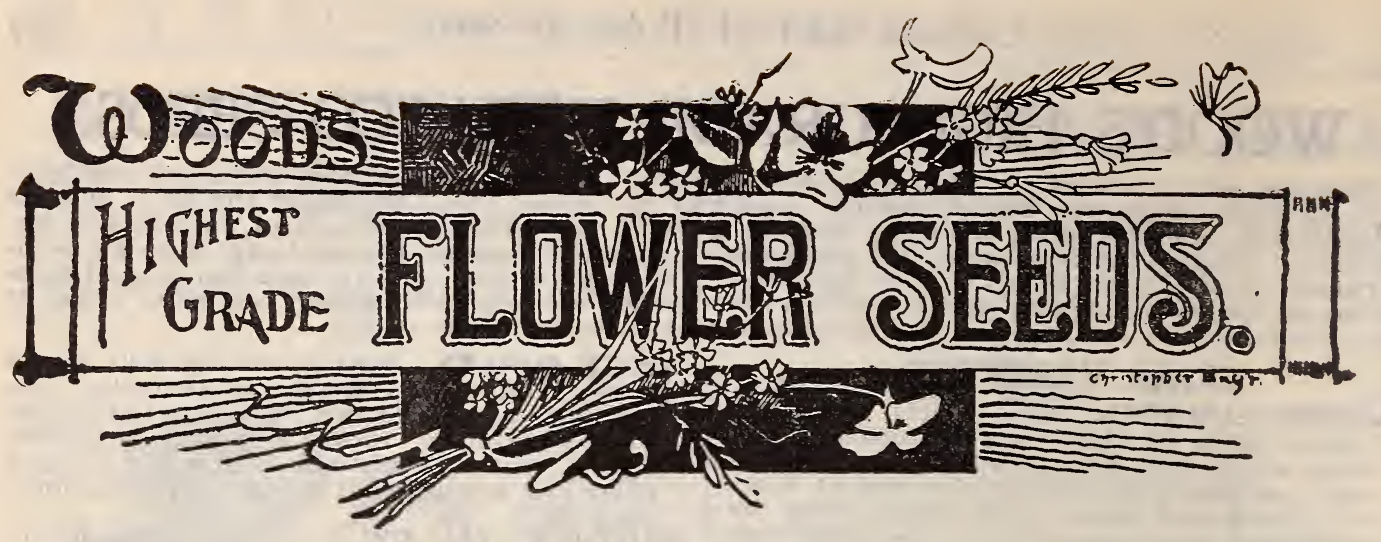

\section{NEW AND LESIRABLE VARIETIES.}

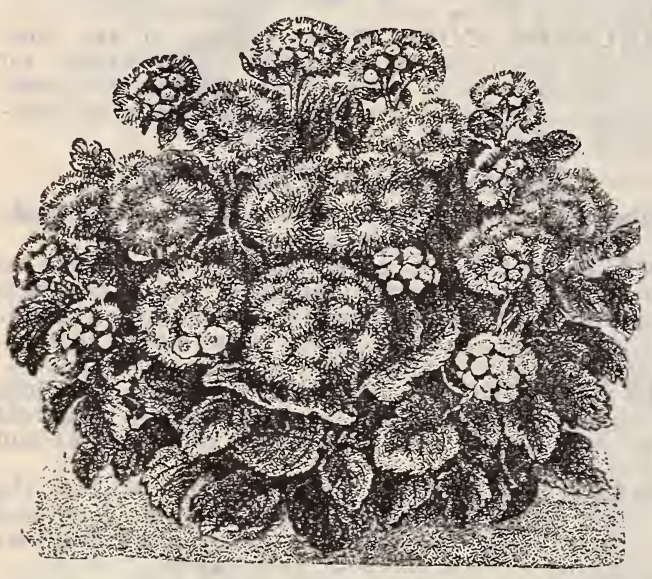

\section{PRINCESS VICTORIA LOUISE AGERATUM.}

This new Ageratum is of extraordinary beauty and loveliness. The dwarf, compact and exact growth makes it specially adapted for bedding and borders. The plant is about three and a half inches high, and six to eight inches wide, with a profusion of rich green, heart-shaped foliage. Every branch produces, in uninterrupted succession, very handsome clusters of delicately fragrant flowers. The color is white, and seems to be covered with a veil of azure blue stamens, but looking straight on the face, appears to be blue with a white centre. Pkt.

\section{IVY - LEAVED SCARLET NAS- TURTIUM.}

Last season we were unable to supply the demand for this distinct novelty. It belongs to the class known as Lobb's Nasturtiums, which produce an abundance of flowers, smaller but far more brilliant than the ordinary Nasturtiums. The ivy leaves are borne on very slender stems, are of a pleasing dark metallic hue, and contrast most strikingly with the crimson scarlet flowers which are borne in great profusion. For hanging baskets, window boxes, vases, or any purpose for which ivy-leaved geraniums are usually employed, it is particularly serviceable. More graceful in habit than the ordinary Lobbianum varieties, and lasts in bloom long after other kinds. This season we expect to fill all orders. Pkt. 10c.

\section{ARCTOTIS GRANDIS.}

A remarkably handsome novelty from Southwest Africa, growing luxuriantly and forming profusely branched bushes about two feet in height and breadth. The leaves are soft and whitish; the flowers, borne on long stems and rising well above the foliage, are large and showy, two and a half to three inches across. The ray florets are pure white on the upper surface, embellished by a narrow yellow zone at their base; reverse of petals pale lilac. In the bright sunlight the flowers spread out almost flat, and the pure white of the ray florets contrasts beautifully with the light blue disc with its projecting white stamens. Of very easy culture, producing splendid flowers in constant succession from early reproduce eighty per cent. true. Pkt. 10c.

\section{DAHLIA "GLORIA."}

Few flowers have advanced in popular favor in recent years as has the Dahlia. The Gloria belongs to a perfectly new race of double Dahlias, producing a great diversity of forms. The flowers vary in size from one to three inches in diameter, resembling in shape the flowers of Double Daisy, Sweet Scabious, Gaillardia etc. their colors being as rich and as varied as in all other classes of Dahlias. As a rule Dahlias do not reproduce themselves true from seed, but the Gloria may be relied upon to reproduce eighty per cent. true. Pkt. 10c.

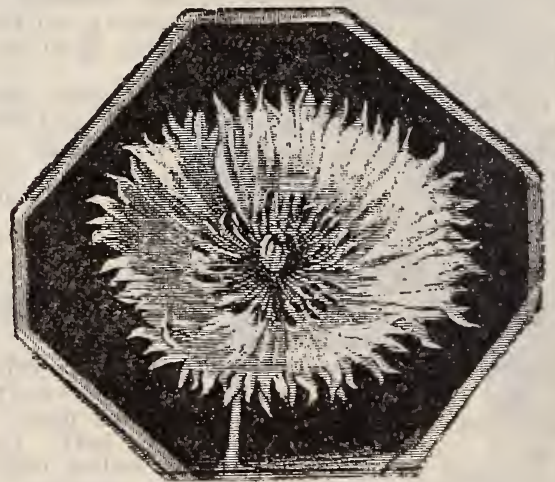

\section{ALPINE FRINGED POPPY.}

A distinct departure in Poppies. Each rosette of pretty grey-green leaves throws up numerous slender flower stalks, bearing delightful flowers of salmon, white, rose or orange, all with yellow stamens, the petals delicately fringed, laciniated and fluted like the edging of fine lace, which gives the blooms a peculiar charm. Fine for permanent border and rock work. Hardy, flowering the first season if sown early. Pkt. 10c. 


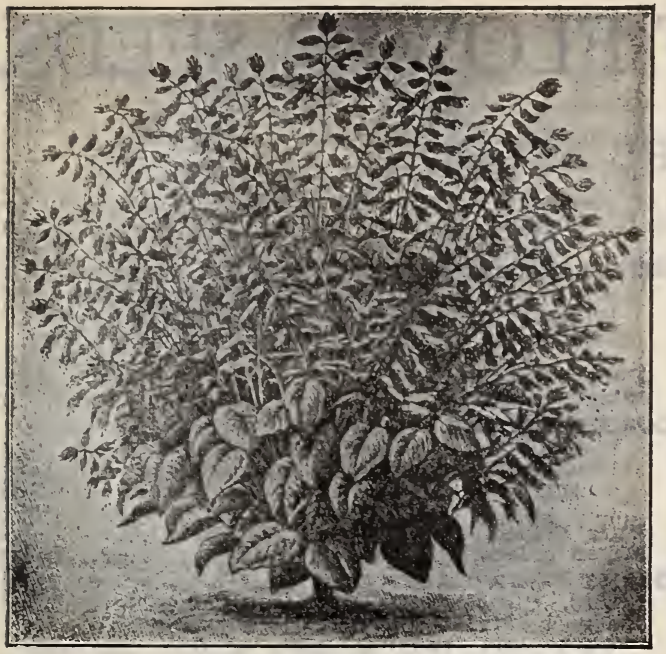

\section{SALVIA "BONFIRE"}

The Bonfire is one of the finest Salvias ever introduced differing from the ordinary Scarlet Sage in that the plant forms a strong, compact, sturdy bush about two feet high, with erect spikes of flowers of the most brilliant scarlet, which stand clear above the dark green foliage and completely cover the plant. It is not unusual to find as many as two hundred spikes to the plant, each bearing thirty to forty flowers each. For masses on the lawn, as a foreground for beds of Cannas and Caladiums, or in rows along the walks its dazzling. brilliant scarlet flowers make a magnificent display. Start in hot-bed or indoors, and it will bloom the first season. Pkt. $10 \mathrm{c}$.

\section{JAPANESE FERN BALL.}

A distinct novelty imported from Japan. It consists of fern roots woven outside and around a ball of moss; these roots produce beautiful sprays of ferns from buds or eyes along their entire length, soon covering the whole surface. Suspend in any part of the room, or may be cut in halves and grown in a fern dish, flat side down. Soak in water for half an hour or longer, and repeat every few days till the growth is started, after which keep moist, and in a short time it will be covered with a mass of beautiful green toliage. If desired, it may be allowed to dry up at any time and put away, and can be again started by watering as before. In this way they may be kept over during the winter, and started again the following spring. 50c. each postpaid.

\section{MINIATURE ZINNIAS.}

The smallest Zinnia in existence, growing only four inches high, with a perfection of bloom not usually found among Zinnias. Of special value for small groups, beds and borders. This novelty was so highly regarded that it was awarded a specia prize by the Hamburg Horticultural Exhibition. The mixture we offer contains all the colors to be found in the tall growing Zinnias. Pkt. 10c.

\section{CONVOLVULUS COMPACTUS.}

\section{(POT MORNING GLORY.)}

Entirely distinct from the running and creeping Morning Glories, and free from the straggling mode of growth characteristic of those sorts. A bed, or even a single pot of this new species, is an attractive sight, in many respects reminding one of compact growing Petunias. Blooms very abundantly, bearing blooms varying in color from white to deep violet. Their value for bedding, pot and window culture, the ease with which they can be grown, and long flowering season, should make them popular favorites. Pkt. $10 \mathrm{c}$.

\section{MINIA TURE VERBENA.}

The value of the Miniature Verbena for bedding and pot culture will be immediately recognized. The plant attains a height of only six inches, and an averase diameter of about twelve inches, the numerous trusses of flowers being borne rell above the foliage, and an almost uniform height an 1 of considerable size. The plant forms a compact, branching bush, without being inclined to irregular and unnecessary growth, blooms continuously and profusely; will be found especially advantageous for window gardening. The miniature form has not been perfected in as wide a range of colors as the ordinary Verbena, but the seeds we offer contain all the colors so far produced, and other colors will be added as they are perfected. Pkt. $15 \mathrm{c}$.

\section{VARIEGATED CANNA.}

A most beautiful and novel tri-colored leaved new Canna, which originated in Solomon Island, in the Southern Pacific, and the most sterling novelty among this class of plants. Its large flowers are brilliant scarlet in color and combined with its handsomely variegated foliage will make the plant a feature in sub-tropical gardening, masses on lawns, etc. The leaves are of a light green, thickly splashed, lined and barred with red and yellow, and margined with clear crimson, which color appears throughout their whole surface. The plant is so decidedly striking as to arrest attention the moment it is seen, and will undoubtedly be in great demand for the purposes to which it is so well adapted. It is as hardy as all other Cannas, of dwarf, spreading, ample habit. Pkt. $15 \mathrm{c}$.

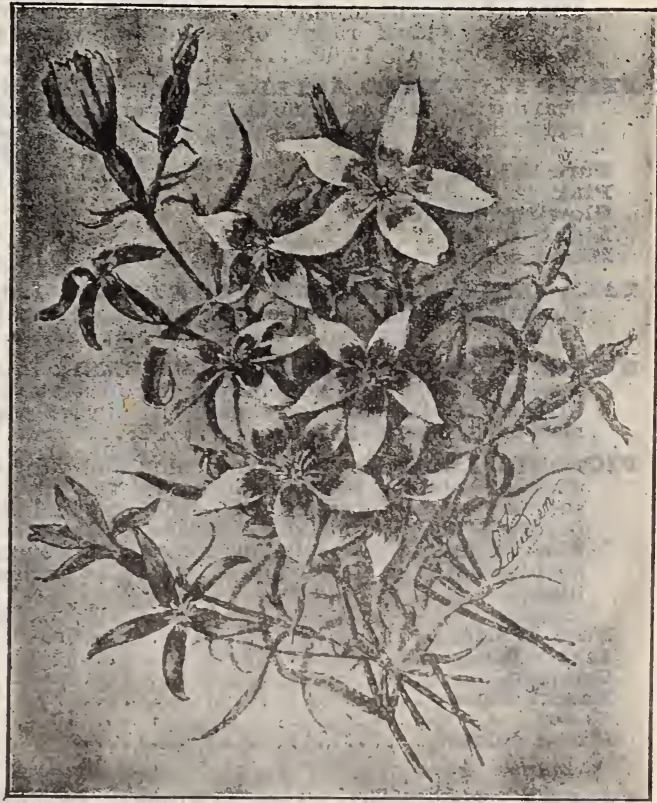

\section{DIANTHUS S'TELLARIS.} (STAR PINK.)

Owing to their brilliancy and variety of color, abundant blooming and easy growth, Pinks have always been one of the most popular summer blooming flowers. The Dianthus Stellaris represents a new class, every flower having the form of a five or six-rayed star. The seed we offer contains all the brilliant colors of the older varieties, but with the further advantage that the flowering season is nearly twice as long, blooming uninterruptedly during the entire summer. Pkt. 10c. 


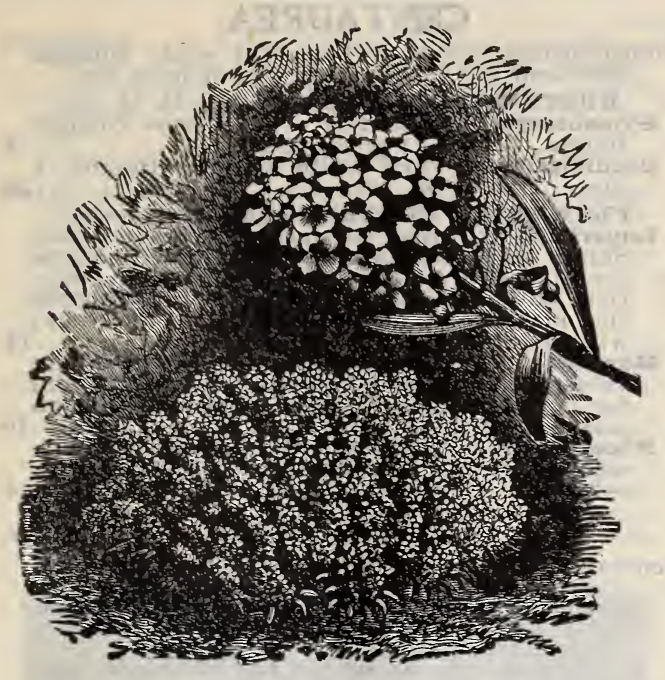

ALYSSUM.

Pkt.

Free flowering, pretty little plants for beds, edgings, or winter blooming. The white varieties are hardy annuals, and bloom all summer.

Saxatile Compactum. A hardy perennial variety of dwarf habit, bearing a profusion of golden yellow flowers in April or May; resists the most extreme weather. Very showy for permanent borders. 9 inches. Oz. $25 \mathrm{c}$., .... 5

Iittle Gem. H. A. New, very dwarf, each plant covering a circle of about 5 inches. Per oz.

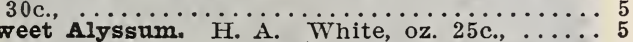

ALONSOA GRATDIFIORA (Mask Flower). A pretty annual, flowering nearly all summer; desirable for bedding. Height, 2 feet. H. H. A.-1-3. Large scarlet flower, $\ldots \ldots \ldots \ldots \ldots 5$

\section{AMARANTHUS.}

Highly ornamental plants. We offer a splendid mixture of all varieties, some valued for beautiful clusters of brilliant flowers, which are very effective for autumn decoration. Transplant 2 feet apart. H. H. A.-2-3.

Mixed varieties. Oz. 20c., ............. 5

AMPELOPSIS VEITCHII. (Also called Boston or Japanese Ivy.) A rapid creeper, with lovely green foliage which turns red in fall. Excellent for covering walls, out-houses, etc. Height, 50 feet. H. P. Oz. 25 c., ........

\section{ANTIRRHINUM (Snap Dragon).}

Showy and useful border plants, producing flowers of a great variety of brilliant colors. Very effective in beds, succeeding in any good gareffective in beds, succeeding in any good garden soil. the first season.

Picturatum. Blotched and spotted, ......... Firefy. Bright scarlet, with white throat, .... 5

AQUIIEGIA (Columbine). Useful summer-blooming plants, bearing peculiar-shaped flowers. Grow 1 to 3 feet high, the stems rising about 2 feet, bearing 50 to 80 blosisoms of various colors. H. P. - 1-2.

Double. Mixed colors,

Single. Mixed colors,

\section{ASPARAGUS PEA.}

Of dwarf, spreading habit, about ten inches high, bearing deep red flowers in great profusion. making a pleasing contrast with the light green of the leaves. Of easy growth, very hardy, and quite a curiosity. Oz., 20c.,

BACHEIOR'S BUTTONS. (See Globe Amaranth.)
BALSAM.

Pkt.

(Touch-Me-Not, or Iady Slipper.) An old favorite, producing large masses of brilliant flowers in great profusion. Our Camelia flowered strain produces the finest double blooms, and is quite a revelation compared with the old varieties. Sow in rich soll for the finest blooms. H. H. A. - 2-3.

White Perfection. The finest white. Per oz.,

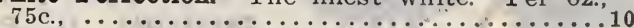
Scarlet. ${ }^{\prime}$ very double, ...................... Solferino. Striped and spotted with lilac and Pink. Rose flowered double, .............. 5

Double Mixed. All colors. Per oz. 50 c., ......

BAISAM APPIE. An ornamental climber, affording an excellent shade. Grows quickly. Its fruit changes from golden yellow to bright red. Plant end of April. Height, 15 - feet. H. H. A. Oz. 25c., .....................

BAISAM PEAR. A desirable climber, bearing large, prickly; pear-shaped fruit, which, when kept in whiskey or alcohol, makes an effective pain-killer and healer of cuts, bruises, etc. Height, 15 feet. H. H. A. Oz. 25c., ......

BALIOON VINE (Love in a Puff). Very pretty and rapid-growing climbers, with inflated balloon-shaped seed pods. Its small, white flowers are produced in abundance. Height, 10 feet. H. H. A. Oz. 20 c., ........... 5

\section{BEGONIAS.}

Beautiful flowering plants for summer bedding or window growing in pots. They are covered the whole summer with beautiful waxy flowers of many brilliant shades, and the foliage is very ornamental. Sown early in the house they bloom the succeeding summer. T. P.$1-3$.

Single Tuberous Rooted. Mixed colors, .....20

Double Tuberous Rooted. Mixed colors, $\ldots \ldots 25$ Rex Hybrida. Beautiful varieties, with handsome large variegated foliage, ............25

vernon. Bears immense quantity of scarlet bloom, making an exceedingly brilliant effect. Foliage ornamental, first green, changing with age until the stems and leaves are suffused with a reddish tinge. Excellent for pots, ...10

BRACHYCOMn (Swan River Daisy). Free-flowering dwart plants, covered with pretty blue and white daisy-like flowers. Valuable for edgings and small beds. H. H. A.-2. Height,

BRYONOPSIS. A climbing annual of the gourd species, with ivy-like, pale green foliage and showy scarlet-striped fruit. Very beautiful. Height, 10 feet. H. H. A., .............

CACAIIA (Tassel-flower). Pretty annuals, bearing tassel-shaped blossoms on long graceful stems. H. A. Height, 2 feet. Mixed colors, . 5

CAICEOLARIA. Gorgeous greenhouse plants producing a mass of beautiful pocket-like flowers in the spring and summer. Colors, yellow, maroon, crimson, etc., spotted and blotched in the most unique fashion. Saved from in the most unique fashion. Saved from

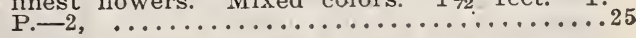

\section{CANDYTUFT.}

Popular favorites, flowering profusely the whole summer. Very valuable for edgings and borders, the plants being fairly covered with masses of various-colored blooms. All except White Perennial are H. A. One foot high.

Empress. A fine variety, bearing large, pure white trusses, in pyramidal shaped spikes. Fine for cutting, or makes a fine bedding Fine for cutting, or makes a fine bedaing

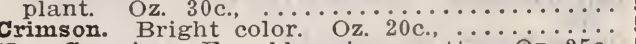
New Carmine. Free blooming, pretty. Oz. $25 \mathrm{c}$., 5 white Rocket. White; large trusses. Oz. $20 \mathrm{c}$., White Perennial. A profuse blooming, hardy variety. Blooms early in the spring, .....10

Mixed Colors. An excellent mixture. Oz. $15 \mathrm{c}$..

CATCHFIY (Silene). A beautiful genus of free flowers. Height, 1 foot. H. A. - 1-2, ...... 


\section{CALLIOPSIS, or COREOPSIS.}

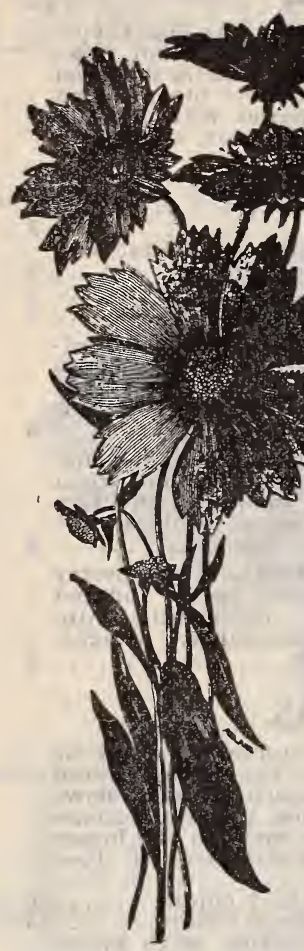

Calllopsis Lanceolata. H. B.-1-2. $21 / 2 \mathrm{ft}$.; bedding annuals, with large, bright golden yellow flowers, v a r i ed with rich brown. Excellent for cutting and decoration. Height, $2 \mathrm{ft}$.

Ianceolata. $\mathrm{H}$. P. Beautiful golden yellow perennial; unexcelled $f$ or borders; excellent for cutting, .....5

Golden Wave. H. A. Large rich golden yellow flowers with brown centres. Very freeflowering. Oz. 25c. 5

Mixed Colors. H. A. Very rich and
showy. Oz. $20 \mathrm{c.}, 5$

CANARY FIOWER. A desirable, rapid-growing, climber, producing an abundance of yellowfringed flowers. H. H. A. Height, 10 feet. Oz. 30 c. 5

CANTERBURY BEIIS (Campanula). Popular and beautiful hardy plants, bearing a great profusion of attractive fell-shaped flowers: Ef-

Single. Mixed colors, ...5 5 Calycanthema (Cup and Saucer). The best variety of Canterbury Bells. The flowers are large and borne in the greatest profusion. Mixed colors, rose, white and

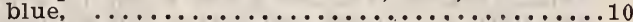

\section{CALENDULA.}

(Pot Marigold). Showy, free-flowering annuals of the Marigold family. Succeed well in any good garden soil, producing a fine. effect in beds or mixed borders, and blooms until beds or mixed borders, and blooms until frost. H. A.-2-3. Height, 1 foot.

Meteor. Pale straw yellow, striped with orange; very double. Per oz. 20c., .......... 5

Prince of Orange. Resembles Meteor, but darker. The stripes are of deep orange. Oz.
25 c. $\ldots \ldots \ldots \ldots \ldots \ldots \ldots \ldots \ldots \ldots \ldots \ldots \ldots \ldots \ldots \ldots \ldots$

\section{CANNA.}

Pkt.

Dwarf French Cannas are of exceptional merit for bedding, and are scarcely less valuable for pots in the winter. Bloom continually throughout the season, bearing large clusters of very showy flowers of different colors. Seed sown in hot-bed in January will begin blooming about mid-summer. File a small hole in outer shell or soak in water thirty-six hours before planting. The tall sorts are excellent for centres of beds and back-grounds.

Crozy's Iarge Flowering. The great merit of Crozy's Cannas lies in the large size and brilliant colors of the flowers, ranging from yellow and orange to the richest crimson and scarlet; some beautifully spotted and edged. The plants are dwarf in habit and the foliage luxuriant Our mixtures include all the newest and most beautiful varieties. Oz. 25c., ...10 Tall Varieties. The best tall sorts. Mixed. Oz. Canna Roots. S........

\section{CELOSIA, or COCKSCOMB.}

Very showy plants, some bearing large ornamentall comb-like heads of various colors, others with beautiful feather-like blooms. Our mixture contains all varieties of both the feathered and combed sorts, many of the latter being cut and ruffied like lace Oz, $40 \mathrm{c}$...... 5

\section{CENTAUREA.}

Highly prized for their beautiful white foliage. Excellent for vases or edgings of beds, etc. DUSTY MIIIER VARIETIES. H. H. P.

Gymnocarpa. Delicately cut silver foliage. Height, 1 foot. Per oz. 50c., .............

Candiåissima. Very white dwarf. Height, 1 foot. Per $1 / 4$ oz. $80 \mathrm{c}$., ....................10 FIOWERING CENTAUREAS. .H. A.-1-2.

Imperialis. A cross between the violet Sweet Sultan and Centaurea Margarita. Inherits the strong growth of the former and beautiful flower of the latter, but is fully double the size; very sweet scented. Cut early; will last ten days in water. H. A., .......10 Margarita. A beautiful large white flowering variety, having a delightful ordor. Splendid for cutting. Water at the roots only, not on

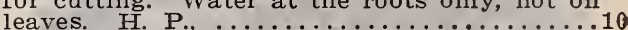

Mixed Colors. Lovely shades of blue, rose, purple and white. Excellent for cutting. H. A.

\section{CARNATION.}

Pkt.

General favorites for their delicious clove fragrance and. diversity of color. Excellent bloomers in the garden, and almost indispensable for winter flowering. H. H. P.-1-2. Height, 1 to 2 . feet.

[NOTE.-To extend the life of plants, keep the blooms picked off.]

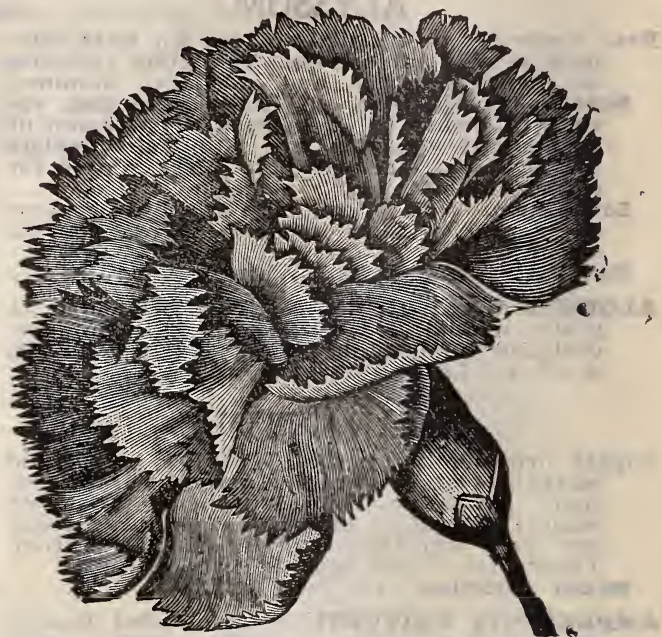

Chabaud's Perpetual. Blooms in seven months, and continues in greatest profusion indefinitely. In view of its earliness, robust growth, hardiness and diversity of color, it is likely to supersede most of the older sorts, ..20

rinest German Double Mixed. A splendid strain for bedding or pots. Florist's pkt. 25c., 15

Marguerite. Blooms four months after sowing. Good for bedding or pots. Plants are dwarf flowering very profusely. Blooms double and ranging through the various shades of red, pink, white, etc. $1 / 4$ oz. $30 \mathrm{c} ., \ldots \ldots \ldots \ldots \ldots$

pink, white, etc. $1 / 4$ oz. 30 c., $\ldots \ldots \ldots \ldots \ldots \ldots$

CENTRANTHUS. Pretty compact plants, bearing clusters of small pink or white flowers. Suitable for rockeries or vases. H. A.-1-3.
Height, 1 foot, ...................

\section{CHRYSANTHEMUM.}

These bear no resemblance to the autumnal varieties, but have a beauty distinctly their own. Grow 12 to 18 inches high, have fine, delicate foliage, and beautiful daisy-like flowers.

Mixed Varieties. A splendid mixture of all varieties, both double and single. Oz. $30 \mathrm{c}$., ...5

Japanese. Perennial varieties bearing fantastic double flowers. All colors mixed, ........10

CINERARIA. Magnificent plants for greenhouse or conservatory. Bear large clusters of flowers in shades of white, violet, blue and crimson. Sow in summer in boxes, and transplant to pots for spring blooming. T. P., ...25 
Crarkia. A hardy free-blooming, handsome plant, of easy culture. Blooms throughout the season. Double and single mixed, all colors, ....... 5

\section{CLEMATIS.}

Hardy climbers, bearing clusters of beautiful flowers of various colors. Soak the seed in warm water 24 hours before sowing. $H$. P.

Iarge Flowering Fybrids. Flowers over 9 inches in diameter. Fine strain...........10

Flammula. Pure white. Sweet-scented,........5

\section{COSMOS}

Among the most useful and satisfactory flowers for late display. The plants grow 3 to 5 feet high, and form masses of elegant foliage until blooming season begins, when each plant bears hundreds of large, showy blossoms 2 to 5 inches across and of various shades. from pure white to crimson. Particularly fine for cutting and house decoration, and are of easy culture. H. A.

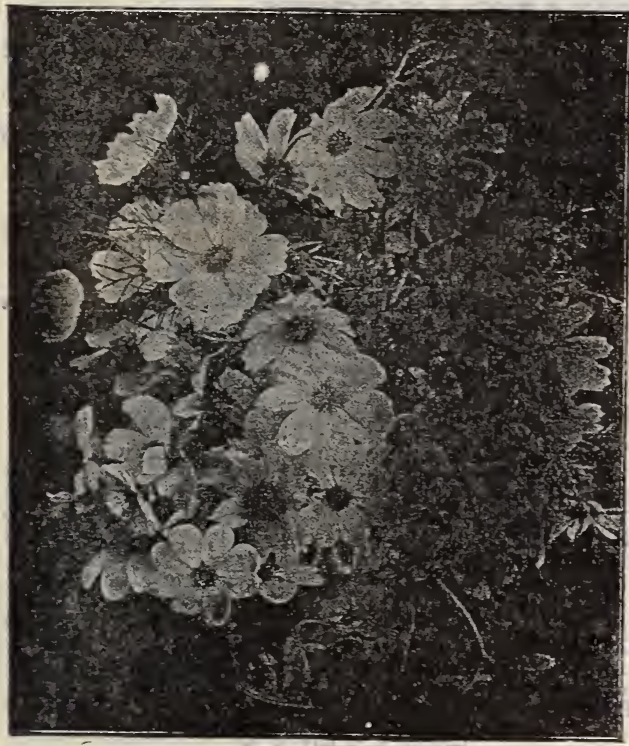

Wood's Farly Flowering. With the introduction of this sort the blooming season is extended nearly two months, whereas, heretofore, the season was confined to the late summer and autumn. Begins to flower about July 1st, gradually increasing until the plant is a mass of bloom. Particularly fine for vases and house decoration, retaining their freshness long after cutting. All colors mixed. Per oz. long after cutting. All colors mixed. Per oz. $40 \mathrm{c}$.

wood's superb cosmos mixture. A truly superb mixture of the largest and best varieties; flowers often measure 4 to 5 inches across, and of the most beautiful colors. Particularly suited for vases and table decoration, remaining fresh in water for several

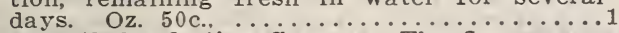

Mammoth Perfection Cosmos. The flowers are double the size of the old, large flowering Cosmos, measuring 3 to 4 inches across. The petals are large, over-lapping, forming perfectly round flowers, deeply ribbed, and of good substance. Separate Colors, white. crimson, pink and vellow. Each, per oz. 40c., . .10

Marguerite. One of the prettiest and daintiest of Cosmos. Flowers measure $21 / 2$ to 3 inches of Cosmos. Flowers measure $21 / 2$ to 3 inches ciniated or fringed. The blossoms resemble Marguerites, but are much more dainty, ...10

Mixed Cosmos. A fine mixture of the older varieties, containing all shades of color. Oz. $25 \mathrm{c}$

\section{COLEUS.}

Pkt.

Popular foliage plants for bedding and edging. Although perennials, they attain perfection the first season if sown early in the house. Our seed is from the best strains, and will produce plants of desirable markings, ........10

COBAEA SCANDENS. One of the best summer climbers, with fine foliage and large, bellshaped, purple flowers. Grows very rapidly, often attaining a height of 20 to 30 feet. place the seed edgewise and cover lightly. Start in house and transplant in May. H. H.

cucüris (Snake cucumber). Ornamental climbers, bearing curious fruit; growth luxuriant. H. H. A.

CXPRess vine. One of the prettiest climbers For best results, sow the seed thickly, so as to make a thick growth. Sow middle of April. Height, 10 feet.

White or Scarlet. Separate colors. Oz. 20c., ..

Mixed Colors. White and scarlet. Oz. $20 \mathrm{c} ., \ldots$

CYCLAMEN PERSICUM.

Pkt.

Exceedingly beautiful winter and spring plants for window or greenhouse. The foliage is highly ornamental, and the flowers of curious shape and striking beauty; blooms continuously for months. Seed sown in boxes in February or March and transplanted to pots will flower the following winter and spring. T. P. Height, 9 inches. Mixed colors, ......10

\section{DAHLIA.}

Dahlias succeed admirably from seed, blooming the first season if started early indoors. Many beautiful sorts are contained in the stocks we offer, and there are always sports which may develop into fine new sorts. which may develop 4 to 6 feet. H. H. P.- -3 .

Double Pompone or Bouluet. Mixed colors, ...10

Cactus. Mixed colors, . ................10

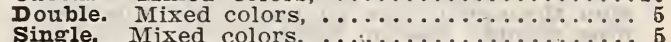

DAHIIA ROOTS. 15c., each; $\$ 1.25$ per dozen. For varieties, see page 54.

\section{DAISY.}

(Bellis Perennis). An old favorite, bearing double white and pink flowers in greatest profusion. Sown in the fall or early in the house will produce flowers from April to June. H. P. Height, 6 inches.

Double Mixed, $\ldots \ldots \ldots \ldots \ldots \ldots \ldots \ldots \ldots$

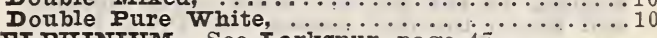

DEIPHINIUM. See Iarkspur, page 47 .

DIGITAIIS (Furglove). Handsome, stately plants, with ornamental green leaves and pendulous flowers, white, pink, blue, purple, etc., spotted beautifully, resembling Gloxinias. H. P.-1-2. Height, 2 feet. Mixed inias. H. P.-1-2. Height, 2 feet. Mixed

DoIICros (iryacinth Bean). Annual climbers of rapid growth, bearing large clusters of purple and white flowers, followed by bright purple pods. Oz. $15 \mathrm{c}$.

ESCHOITzIA (California Poppy). 'Showy freeblooming plants for bedding. Flowers are of extremely rich and beautiful colors. Height, 1 foot. H. A. - 1-3.

Mandarin. Orange and scarlet. A beautiful

zose Cardinai. 'Beautiful pink; wonderfuliy effective,

Mixed Colors. Oz. 25 c. $\ldots \ldots \ldots \ldots \ldots \ldots \ldots$

FERNS. Beautiful decorative plants; thrive best in peaty, sandy soil. Sow in boxes or pots, barely covering the seed, and keep moist. T. P. Choice varieties mixed, .............15

FOUR O'CIOCK. (See Marvel of Peru.)

FORGET-ME-NOT (MYOsotis). Popular and charming little plants, bearing delicate blue flowers, which are highly prized for their
modest beauty. H. H. P.-1-2.

Eliza Fonrobert. Large flowering, strong growing sort. Remarkably fine. The central jpestris. A dwarf free-flowering sort. Mixed

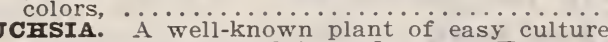
having bright pendulous flowers. Excellent for pots or bedding in partially shady situations. T. P. Mixed colors,

0

\section{5} 5

5

t.
10 


\section{DIANTHUS, or PINKS.}

One of the most brilliant of our garden flowers, and gives universal satisfaction. The plants are symmetrical in growth, and produce a profusion of bloom throughout the summer. Very fragrant and desirable for bouquets. H. A. Height, 1 foot.

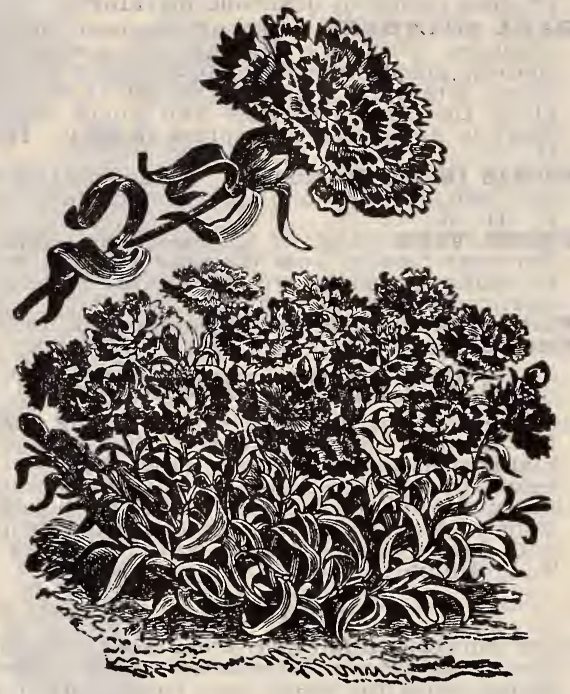

GAILLARDIA.

The large and brilliant flowers, which are exce lent for cutting, are produced in great profusion throughout the summer; desirable bedding plants. Sow in April.

Iorenziana. Double; fine for massing. H. A.,. 5

Grandifiora. Hardy perennial varieties, bearing gorgeous flowers $21 / 2$ to 3 inches across. gorgeous flowers $21 / 2$ to 3 inches across.

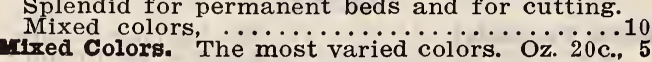

\section{GERANIUM.}

One of the most popular plants for bedding or keeping in the house. Sown early indoors will bloom the first season. T. P.-1-3.

zonale. A mixture of the finest sorts, ......10 Apple Scented. Leaves very fragrant; makes fine plants from seed. Sow in light soil and

GIIIA. Profuse blooming and handsome; fine for 1 massing in flower beds. Mixed colors. H. A.

GIOBE AMARANTH (Bachelor's Buttons). Popular everlastings, which form bushy plants about 2 feet high, bearing hundreds of flowabout 2 feet high, bearing hundreds of flowers. Excellent border plar

mised Colors. White, purple, crimson, etc., ... 5

GI0XINIA. Charming greenhouse plants, producing in greatest profusion, flowers of the most exquisite and gorgeous colors, often 3 to 4 inches across; many are magnificently spotted, mottled and blended. Under the most ordinary culture they bloom continuously for months. T. P.-1-2. Height, 1 foot.

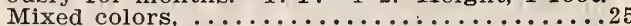

GODETIA. Very attractive hardy annuals, flowering profusely early in the season. Of dwarf habit, flowers 3 to 4 inches across, of

GOURDS. Of exceedingly rapid growth and luxuriant foliage, bearing gourds of various shapes and sizes, some quite ornamental, others useful. T. A. Height, 10 feet. Dipper, Bottle, Nest Egg, Iemon, Orange, Miniature, and Hercules Club. Separate sorts. Each, oz. 30c......................... 5

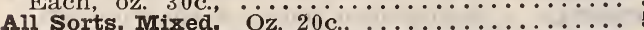
Dish Cloth. A splendid ornamental climber. The inner lining makes admirable bath and
dish cloths. Oz. $30 \mathrm{c} ., \ldots \ldots \ldots \ldots \ldots \ldots \ldots$

WOOD'S SUPERB DIANTHUS MIXTURE. Pkt. questionably the best Dianthus mixture, embracing the most attractive varieties of both single and double sorts. The flowers are large and of the most brilliant colors, varying from pure white to the richest crimson. Particularly fine for cutting for house and table decoration, .......................10

DOUBIE ANNUAI VARIETIES:

Chinensis. Double China or Indian Pink. Our mixture of this strain is extra fine, and con-

tains a large variety of colors. Oz. 25c., .... reddewigii. Double Japan Pink. The flowers are large and of the brightest colors. Mixed

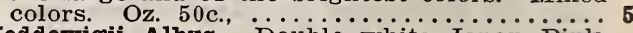

Feddewigii Albus. Double white Japan Pink,

Oz. $\$ 1.00, \ldots \ldots \ldots \ldots \ldots \ldots \ldots \ldots \ldots \ldots \ldots \ldots \ldots \ldots \ldots \ldots \ldots$

Imperialis. Double Imperial Pink. An abundant bloomer. Mixed colors. Oz. 40c., .... 5

SINGIF ANNUAI VARIETIFS:

Heddewigit. Beautiful rich colors. One of the finest annuals for show and cutting. Oz. $40 \mathrm{c}$., 6 Iaciniatus. Beautiful fringed variety of bril-

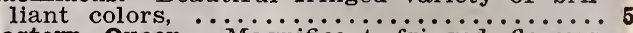

Fastern Queen. Magnificent fringed flowers, beautifully marbled and stained. Very showy, 5

PERENNIAI OR HARDY VARIFTY:

Pheasant Fye. A beautiful single variety, clovescented. Flower large and finely fringed.

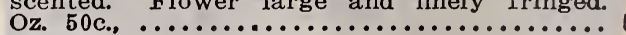

kt.

HELIOTROPE.

fragrant plants, useful either for bedding purposes or pot culture. Can be raised from seed as easily as Verbena, blooming the first season. T. P. - 1-3. Height, 2 feet.

Iremoine's Giant. A new strain, the flowers often measuring 10 to 12 inches across. Al shades, from pure white to deep purple, and deliciously fragrant, ..................15

Blue. Flowers very dark and fragrant, .....10

White. Bears its flowers in large clusters, ..10

White. Bears its flowers in large clusters, ..10 HEIICHRYSUM (Fternal Flowers). One of the best everlastings, bearing large double flowers; showy and attractive for borders. H. A.

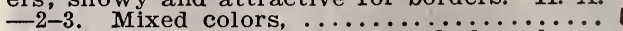

HIBISCUS. A showy and ornamental plant, bearing beautiful single flowers 3 to 4 inches in diameter.

Africanus. White with black eye. H. A., ....

\section{HOLLYHOCK.}

Stately and showy early blooming plants. Flowers perfectly double and of great variety of colors. Perfectly hardy, and blooming year after year when once planted. H. P. Sow in May or June. Colors: White, Pink, Scarlet, Yellow, all double. Separate colors, pkt. 10c. All colors, mixed, 1/4 oz. $25 \mathrm{c}$. ..............

All colors, mixed, $1 / 4$ oz. 25 c., . -............. orleghen, fringed variety of Hollyhock, which will stand the winter and bloom throughout the summer till frost. In the far South they will bloom the year round. The nearly transparent and chrysanthemum shaped flowers, seldom less than five inches across, range from semi-double to double, are beautifully from semi-double to double, are beautifunce fringed and curled, and have the appearance
of crushed satin. $1 / 4$ oz. $40 \mathrm{c} ., \ldots \ldots \ldots \ldots \ldots 10$

HUMUIUS. Very ornamental and fast-growing. climbers. The foliage is a lovely green, stands drought, insects, etc., retaining its fresh color till late in the fall. Splendid for covering verandas, trellises, etc. T. A. covering verandas,

Japonicus (Japanese Hop). Dark green foliage, 5 Variegated. Japanese Hop. with dark green leaves shaded and marbled with silvery

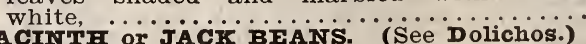
FYACINTH or JACK BAANS. (See Dolichos.) ICE PLANT. Pretty trailing plants, with curious ing baskets. Start in house or hot-bed. T. A. 


\section{LARKSPUR.}

Dwarf German Rocket. The popular annual variety for summer garden decoration. The flowers are of varied colors, and are borne on long spikes, rendering them of exceptional value for cutting. H. A. Height, 1 foot, ..

Perennial Iarkspurs. Splendid hardy plants, with beautiful, graceful spikes of flowers of many exquisite shades. Invaluable for permanent beds or borders, or in the corners or edges of the garden. Sown in the fall or early in the spring out-doors, they bloom the succeeding summer. H. P. - - 2-3. All colors, mixed, ......................

IINUM. A pretty annual, covered with bright red flowers borne on slender, graceful stems. Splendid for massing. H. H. A.-2-3. Height,

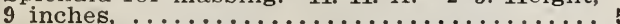

\section{LOBELIA.}

Pretty profuse-blooming plants, of great value for edging as well as for hanging baskets or vases.

Annual sorts. Mixed colors,

IYCZnIS-Chalcodonica. Handsome and useful plants, bearing very showy flowers of many colors, 2 feet high. H. P.-1-2. Blooms first

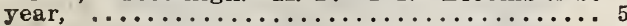

\section{MIGNONET'TE.}

Goed for pots or garden culture, but for the finest blooms should be in a partially shaded situation. If thinned out, will produce stronger plants and blooms. Sow at intervals throughout the summer for a succession.

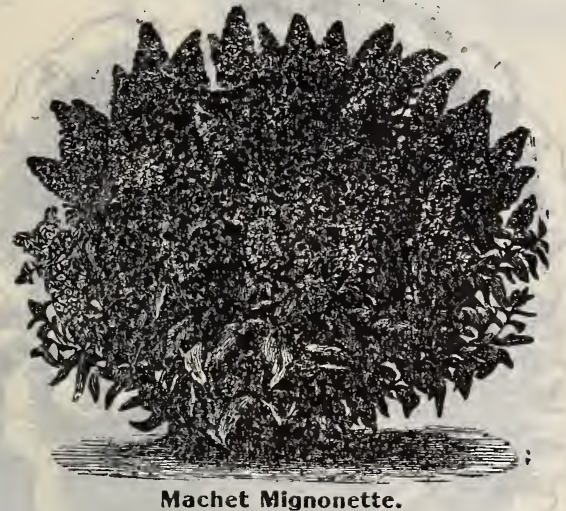

Goliath. Of candelabra-like growth with rich green foliage and immense trusses of pure bright red flowers, immense trusses of pure

Defiance. A strain of remarkable size, the spikes often 10 to 12 inches in length. Deliciously fragrant and excellent for cutting, keeping fresh a long time. Oz. 40c., ........1

Machet. One of the best sorts; of bushy, vigorous and symmetrical growth. Bears massive spikes of very fragrant red flowers. Fine for pot or garden culture. Oz. $35 \mathrm{c}$., ...........

victoria. Dwarf branching variety with large trusses of deep red flowers. A robust and

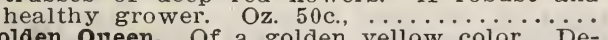

liciously fragrant; none better for cutting. liciously fragrant; none better for cutting. Crimson Giant. One of the best large flowering sorts. A very free bloomer. Oz. $35 \mathrm{c} ., \ldots \ldots$.
sweet. fragrant; large flowering. Oz. 10c., ......5

\section{MARIGOLD.}

Easily grown and useful plants. The African are tall, about 2 feet high, and most striking in large beds; the French are dwarf, and best adapted to small beds, or as a fore-ground to taller plants. H. A.- 2-3.

French Gold Striped. Of dwarf habit; flowers rich maroon, striped with golden yellow. Very free flowering. Oz. 30c., .............. 5
French Double Dwarf. A splendid mixture of rich colors. Oz. 20 c., A splendid mixture of

Eldorado. An African variety, producing flowers 3 to 4 inches in diameter. Colors from pale yellow to deepest orange; very double.

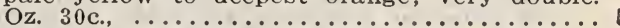

African. Old favorite in every garden, but greatly improved in size and form; a fine mixture of the best varieties. Oz. $20 \mathrm{c} ., \ldots . .$. ...

\section{MORNING GLORIES.}

Rapid growing vines of the Ipomea family; useful for covering arbors, porches and trellises bearing an abundance of showy flowers of all colors. Height from 10 to 50 feet.

Imperiai Japanese Morning Clory. One of the grandest of all climbers. Their chief "glory" lies in the unusual size of the flower, measur ing from 4 to 6 inches across, and in limitless variety of shadings, colorings and markings; all shades of white, silver gray, yellow, copper color, bronze and almost black, some striped, blotched and spotted; others have a distinct marginal band, others odd and peculiar shapes. The foliage is quite ornamental, some leaves mottled and checkered; some rich, vivid green, others silvery white, others yellow. Sow in a warm, sunny situation, in rich soil, giving-plenty of water in dry weather. Oz. 25c., .....................

Brazilian Ixorning Glory (Ipomea Setosa). A very vigorous and luxuriant annual. Grow 30 to 40 feet, branching in every direction and make a very thick shade. The flowers are from 3 to 4 inches across and of a beautiful rose color. Its immense leaves and large clusters of curious seed pods render it very ornamental. Excellent for porches or arbors. Oz. 40c., .........................10

Convolvulus Major. The well-known Morning Glory. All colors mixed. Oz. 10c., .........

Convolvulus Mauritanicus. Blue; splendid for vases, hanging baskets and trailing, ........

\section{MOONFLOWER, or Evening Glory.}

Beautiful rapid climbers, bearing large white flowers 4 to 6 inches in diameter, which open in the evening and on cloudy days. Start in the house and transplant when the weather is warm. Before planting file a small hole in one end through the outer hull and soak for 36 hours in warm water.

Ipomea Grandiflora Albus. The original Moon40 to 50 feet. Oz. $75 \mathrm{c}$., $\ldots \ldots \ldots \ldots \ldots \ldots \ldots \ldots 10$
$4 . \ldots \ldots \ldots \ldots \ldots$

Ipomea Hybrida. Similar to above but blooms much earlier. Oz. 75 c., ...................

MARVFI OF PERU (Foux O'clock). Well-known and popular flowers; open only in the evening, or on cloudy days. Colors, white, yellow, crimson, striped, etc.; flowers showy and in crimson, striped, etc.; flowers showy and in great profusion. Blooms first season. Height,
2 feet. H. H. B. Mixed colors. Oz. 15c., .. 5

MaURANDIA. A ost beautiful summer climber with graceful foliage and elegant and dainty pendulous flowers resembling Digitalis. Start in the house and transplant to open ground in May. T. P.-1-3. Height, 10 feet, ....10

MrmuIUS MOscratus. The well-known musk plant. Leaves highly scented; bears small yellow flowers. Quite tender, and do best in moist, shady locations, ...................

NEMOPHIIA. Dwarf plants, bearing in greatest profusion pretty delicately shaped blue and white flowers. H. A.-1-3. Height, 6 inches. Mixed colors, ..........................

IrGEILA (Love in a Mist). Interesting blue and white flowers, partially concealed in a veil of delicately rut foliage. H. A.-2-3. Height, 1 foot. Mixed colors, ................. 5

OxaIIS. Splendid little plants, with bright-colored flowers; desirable for hanging baskets rock-work or edgings. H. H. P.-2. Mixed

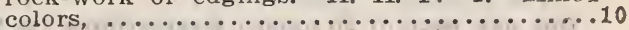




\section{NASTURTIUM.}

Valuable summer flowering plants; the leaves are a glossy green and the flowers of all colors, beautifully shaded. The Tom Thumb varieties grow one foot high, and make very effective bedding plants, blooming profusely the whole summer. The tall sorts grow 6 to 10 feet, and are excellent as climbers and trailers. H. A. $-2-3$.

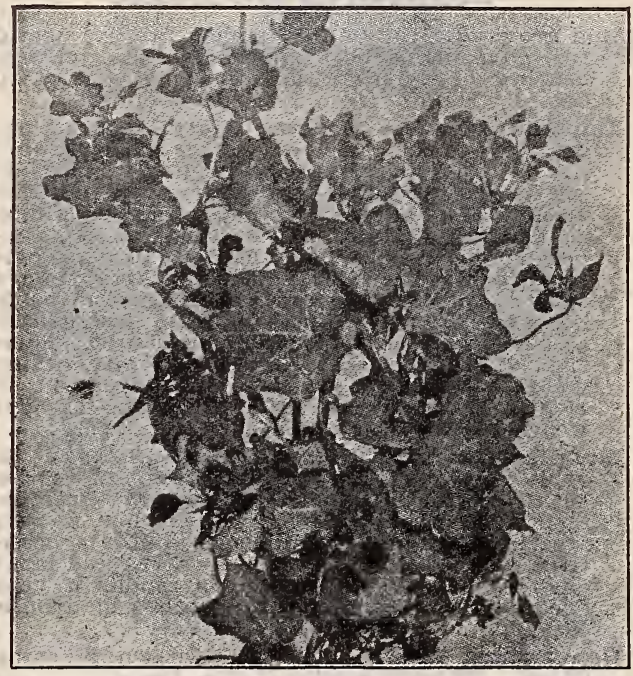

Ivy-Leaved Nasturtium.

IVY IFAVRD NASTURTIUM. For description, see Varieties of Special Mrerit, page 40 . Oz.

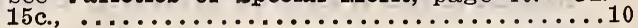

DWART ON TOM THUMB NASTURTIUMS.

Chameleon. Produce flowers or different colors, and great variety of shading on a single

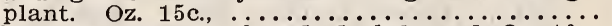
King Theodore. Black red; dark leaved. Oz. $10 \mathrm{c}$., 5 Bronze. Singular glossy shade. Oz. 10c., ..... 5 Empress of India. Foliage dark; brilliant crim-

son. Oz. 10c., ...................... Pearl. Pure white flowers, fine for contrast. Golden ring. "Brilliant yellow flower. Oz. ioc., 5 King of Tom Thumbs. Scarlet; dark foliage.

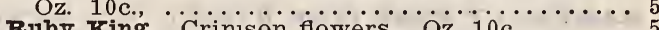

Ruby King. Crinison flowers. Oz. 10 c., $\ldots \ldots \ldots$ Spotted. Beautifully blotched. Oz. 10c., .... 5

Dwarf Varieties Mixed. $1 / 4 \mathrm{lb}$. $25 \mathrm{c}$; ; oz. $10 \mathrm{c} ., \ldots 5$

TAII OR RUNNING NASTURTIUMS.

Chameleon. Flowers similar to Dwarf Chameleon. Oz. 15c., ..................... White Pearl. Cream white. Oz. 10c., ...... 5 Scarlet. Bright orange scarlet; free bloomer, 5 Regaleanum. Violet crimson. Oz. 10c., ..... 5 Feinemanni. Chocolate Oz $10 \mathrm{c}$........... Feinemanni. Chocolate. Oz. 10c., $\ldots \ldots \ldots \ldots$....... Hemisphoericum. Straw color, with rosy scarOrange. Rich orange, with red blotches. Oz. $10 \mathrm{c}$

Dark Crimson. Showy fiowers oz. $10 \mathrm{c}^{\prime} \cdots \cdots$ Iemon Yellow. Very vigorous; bright color. Oz 10c.

Eybrids of iradam Gunther. Exceedingly brilliant colors, containing many new shades and beautifully and distinctly marked flowers.

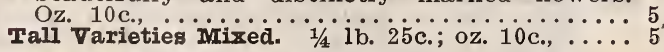

\section{IOBB'S NASTURTIUMS.}

Very pretty varieties, growing taller than the preceding kinds; flowers and leaves smaller, but brilliant. Mixed. Oz. 10c., ............ 5 One plst. each of 20 named Nasturtiums for $75 \mathrm{c}$.

\section{WOOD'S ROYAL PANSIES.} PANSIES-MIXED COLORS.

Pkt.

Wood's Exhibition. Unexcelled for its varied and beautiful colors. The flowers are very large, of most brilliant and effective markings, and matchless form and beauty. Particularly fine for florists, or where large show Pansies are desired. $1 / 8$ oz. $\$ 1.25, \ldots \ldots \ldots 25$

wood's Royal Mixture. A magnificent mixture of the finest named Pansies. It excels in an endless variety of the richest colors, which, with the large size and perfect form of its blooms, make it indeed a "royal mixture." 3 pkts. for $25 \mathrm{c}$; ; $1 / 8$ oz. $50 \mathrm{c}$, $\ldots \ldots \ldots \ldots \ldots$

Masterpiece. The highest attainment in Pansies, and the most distinct and novel. The ruffled blooms, often 3 or more inches across, are of great substance, are borne well above the foliage, and are the ric..est colors, ....15 Trimardeau. A remarkably large and distinct class, individual blooms sometimes 3 inches across. Splendid colors mixed. $1 / 8$ oz. $35 \mathrm{c}$., .10

Inglish Show. Curiously marked with a welldefined "face." Various colors. 1/8 oz. 20c., 10 Odier, or Blotched. A magnificent French strain, producing extra large, perfectly formed round flowers of good substance. Each of the five petals is ornamented with a clearly-defined blotch or eye. $1 / 8$ oz. $50 \mathrm{c}$., ...10

Iarge Flowering Mixed. A good mixture of large flowering Pansies, embracing all colors and styles of blooms; very showy. $1 / 4 \mathrm{oz}$.

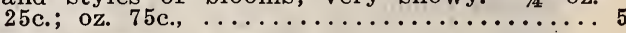

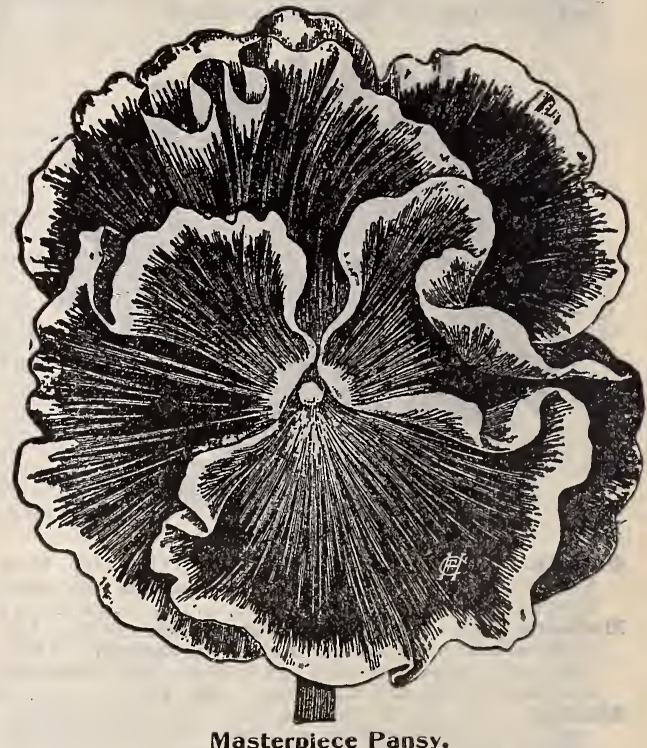

PANSIES-SEPARATE COLORS.

5c. pkt.; $1 / 4$ oz. $30 \mathrm{c}$; 1 pkt. each of 12 sorts for $50 \mathrm{c}$. Cardinal. Brilliant brownish red; very striking. Emperor Frederick. Dark red, bordered with orange scarlet.

Emperor William. Ultramarine blue, with violet eye; one of the best blues.

Faust, or King of the Blacks. Very dark, almost black; distinct and fine.

Fire King. Golden yellow, the upper petals reddish brown. margined yellow; very showy.

Gold Margined. Mahogany brown, with gold border Iord Beaconsfield. Large violet, shading off to white on upper petals.

Iight Blue. Lovely sky blue, with dark eye. Meteor. Yellow, spotted with brown and margined with gold or silver. Splendid.

silver Idged. Dark purple, with a distinct white edging.

Snow Queen. Beautiful large pure white.

Yellow. Bright' golden yellow, with dark eye. 


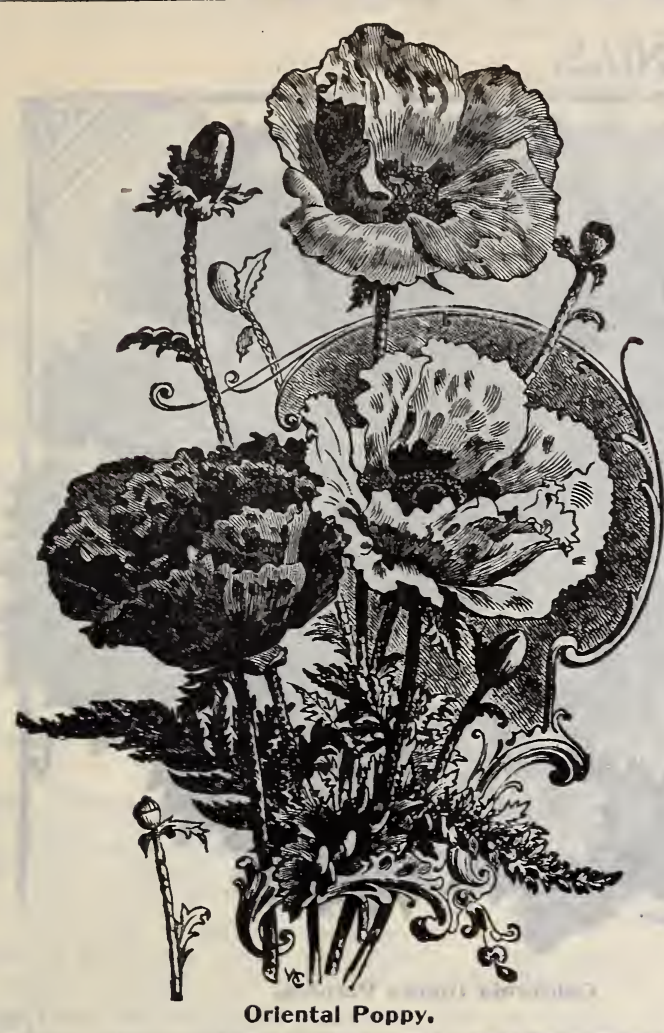

\section{POPPIES.}

Poppies succeed remarkably well in the South, and hardly any class of plants afford the same brilliant colorings and showy display. Very eassy culture, being sown where they are to bloom. The varieties we offer are the best and can be depended on to produce satisfactory results, all being selected strains.

WOOD'S SUPERB POPPY MIXTURE. A grand mixture of all the single and double varieties. The wonderful variety and brilliant colorings of this mixture make a very effective display in the garden or for cut flowers. Oz. 50c., ...10

PERENMIAL POPPIES. H. P.:

Oriental. One of the grandest of all Poppies. The flowers are extremely large, a rich dark glowing crimson, the foliage very rich dark green. If sown early will bloom the first

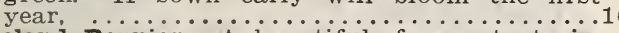

Iceland Poppies. A beautiful, fragrant strain which blooms continually from June to Octaber. Flowers resemble crushed satin; will continue to flower for 3 or 4 years. Mixed

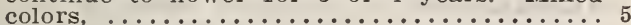

DOUBIE ANNUAI POPPIES:

Cardinal. The plants grow about 18 inches high, bearing large, very double glowing scarlet flowers, a striking contrast with the deeply cut dark green of the foliage. Oz. 40c.,

White swan. A splendid new variety, with immense double white flowers beautifully fringed. Oz. $40 \mathrm{c} ., \ldots \ldots \ldots \ldots \ldots \ldots \ldots$

Mikado (Striped Japanese Poppy). A beautiful sort, having the petals twisted and curved like a Japanese Chrysanthemum. Colors, scarlet and white, fringed edges; very distinct. Oz. $40 \mathrm{c}$.

Carnation Flowered. A magnificent Poppy of dazzling richness and variety of colors; flowers beautifully fringed. Oz. $20 \mathrm{c} ., \ldots \ldots \ldots \ldots$

Peony Flowered. Splendid, large and very dou-

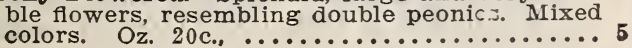

\section{SINGIE ANNUAI POPPIES:}

Pkt.

New Fayal. Exceedingly beautiful dwarf poppies, producing both double and single blooms aginable poppy color, .......10

Tulip. This sterlin variety, originally from Armenia, bears : abundance large, bright scarlet flowers, so dazzlin - as i remind one of a bed of scarlet tulips, $\ldots \ldots \ldots \ldots \ldots \ldots 10$ Shirley. These eautiful oppies are very free They range in color fiom pale rose to deep crimson, and are delicately edged and fringed. If cut when young will last several days in water. Mixed colors. Oz. 40c., ......... 5

Danebrog. Large, bright scarlet, with a white spot on each petal forming a cross. Oz. 30c.,
Rich vermillion, with a shining black spot on each petal, of dwarf branching habit. Oz. 40c., ......................

\section{PHLOX DRUMMIONDI.}

One of the prettiest and most popular of garden annuals. Make very attractive beds, and continue in bloom throughout the summer. As valuable as Verbena for cut flowers. Sow in April in open ground, or can be started earlier indoors. The double varieties will come more true to type if planted in sandy soil.

Dwarf Phlox. Exceptionally fine for growing in pots and for bedding and borders. Brilliant in color and p"ofuse in bloom. Height, 6

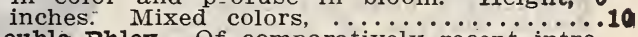

Double Phlox. Of comparatively recent introduction, but rapidly coming into popular favor. The blooms range from semi-double to double, are borne profusely; and are specially desirable for cut flowers, being more lasting than the single sorts. All colors, mixed. $1 / 8$ oz. 40 c., ............................. 10

star and Fringed. Dwarf varieties, bearing brilliant fringed and star-shaped flowers. Exceedingly pretty. Mixed colors. $1 / 4$ oz $25 \mathrm{c}$., 10

Mixed Phox. A splendid mixture of all colors; Perennial phlox. Excellent sorts for permanent beds, growing 3 feet high. Mixed colors.

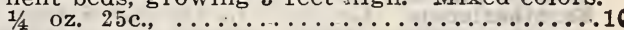

IARGE IIOWERING PHIOX (Grandiflora). The large flowering or grandiflora kinds are a decided improvement on the ordinary Phlox Drummondii, producing flowers nearly, twice the size of the latter with the most brilliant colors.

Pure white. Very fine large bloom, .........10

Scarlet. A profuse bloomer, ..............10 Yellow. Novel and distinct; a fine flower, ...10 Dark Purple. The darkest of all, .........10

Striped. A fine cullection of striped sorts, ....10 Mixed Grandiflora Phlox. A splendid mixture of large flowering sorts. $1 / 4$ oz. $25 \mathrm{c}$; oz. $75 \mathrm{c}$., 10

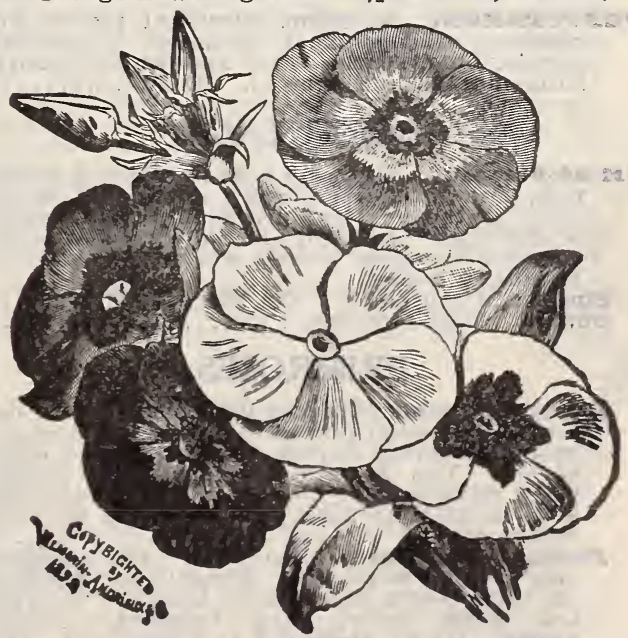

Grandiflora Phlox. 


\section{PETUNIAS.}

Petunias are deservedly popular for bedding purposes. The flowers are large, of brilliant colors, and borne in great profusion. Sow in boxes in the house for early plants, later sow outside. H. $\mathrm{H}$. A. - 2-3. Height, 1 to 2 feet.

California Giants. This splendid large flowering single Petunia is the result of years of careful selection by one of the most eminent Petunia specialists, and is noted for its beautiful combinations and exquisitely marked colorings. The flowers are deepthroated and beautifully fringed, 15

snowball. For an ever-blooming white flower, suitable for beds and borders, this new Petunia has few equals. Of dwarf, bushy habit and bears very profusely snow white flowers of good size and shape, sweet-scented and lasting. Particularly adapted to our climate on account of its heat and drought-resisting qualities. We recommend all admirers of Petunias to give this new sort a trial, ................10

Doublo Petanias. A splendid strain, producing a large percentage of double flowers of the largest fringed varieties in bright colors and tints, beautifully marked. Mixed colors, $\because \ldots \ldots \ldots \ldots \ldots 25$

Single Petanias. A choice mixture of all colors, including many large flowering striped, blotched and fringed sorts. Oz. $5{ }^{n} \ldots 5$

RICINUS (Castor Oil Plant,. Luxuriant annuals with palm-like leaves. Excellent for backgrounds or centres of beds of foliage plants. H. H. A.

Zanzibariensis. Leaves 2 to $21 / 2$ f set across, of various, colors, green, coppery brown, purple, bronze, etc.; stems from green to various shades of red. Exceedingly handsome. All

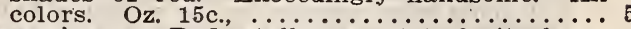

Sanguineus. Red stalks, scarlet fruit, large bronzed leaves. : Oz. 15c., ............... 5

Mixed Varieties. A fine mixture of the best sorts; all colors. $\mathrm{Oz}$. $15 \mathrm{c} ., \ldots \ldots \ldots \ldots \ldots \ldots . .5$

PASSION FIOWRRS. Splendid, hardy climbers, bearing attractive, curiously shaped fringed flowers, deriving its name from the fancied resemblance to a cross. H. H. A. Height, 10 feet. Mixed colors, .................. 5

PENTSTrmor. Excellent perennial plants for borders, bearing most gorgeous blooms of purple, blue, scarlet, rose and white, beautifully marked and spotted. H. P., ........ 5

\section{PORTULACA.}

(Moss Plowers). Succeeds best in a sunny situation, and produces flowers of almost every color in the greatest profusion. The double is especially beautiful and showy. Sow when weather becomes settled warm. T. A. $-2-3$. Height, 6 inches.

single. Mixed colors. Oz. 35 c., ............

Single. Mixed colors. Oz. 35 c., $\ldots \ldots \ldots \ldots \ldots \ldots \ldots$
Double. Mixed colors, $\ldots \ldots \ldots \ldots \ldots \ldots$

\section{PRIMROSES.}

Primula Sinensis (Chinese Primrose). Very desirable perennial plants for house or conservatory; blooming during the winter and early spring. The flowers are large and beautifully fringed, and borne in great profusion. Sow in May or June, transplanting to pots. Mixed colors

Evening Primrose (Öenothera). For summer and autumn flowering. Suitable for margins of shrubberies and mixed border. Flowers are large, showy, and fragrant. Easily grown. H. A. Height, 1 to 2 feet,........ 5

Desirable and showy bedding-plants, ablaze with brilliant flowers from early summer till frost. Seed sown early in the house produces better plants than from cuttings. H. H. P.-1-3. Height, 3 feet.

Splendens (Scarlet Sage). The brilliant scarlet variety so well known. $1 / 4$ oz. $40 \mathrm{c}$., .......10

Patens. Splendid rich blue, very showy, .......15

SAIPIGIOSSIS. A beautiful flowering annual, forming strong, bushy plants about 18 inches high, and bearing large, funnel-shaped flowers of many beautiful colors, exquisitely

SANVITAIIA. Dwarf, free-flowering plants; suitable for borders or rock work. Double golden yellow flowers, like miniature sunflowers, are produced in the greatest abundance. Height, 6 inches. H. A.-2-3, .... 5

SCABIOSA (Sweet Scabious). Bears large, double flowers of many beautiful colors on long, graceful stems; excellent for cutting. H. A.

SENSITIVE PIANT (Mimosa). Curious plants with graceful and elegant foliage. The leaves and branches when touched droop in a most

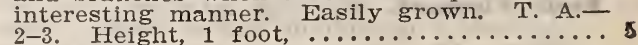
kt.

PYRETrireum. Dwarf plants with golden yellow borders, and edgings. Perennials, but usually grown as half-hardy annuals.

Aureum (Golden Feather). Beautiful yellow Eoseum (Insect Powder Plant). Bright rose

ROSE CAMPION (Agrostemma). Splendid dwarf plants for dry situations, bearing pretty flowfor massing. Height, 1 foot. H. P. Blooms 5 


\section{SWEET PEAS.}

Sweet Peas have all the qualities which are prized in decorative plants-gracefulness of form, brilliant and varied coloring, and delicious perfume. Early in February, in a situation not too sunny, plant three to four inches deep to insure good roots, and two or three times during the season bank the soil against the roots. Sow also in October, giving the plants slight protection during the winter. Don't gather the blooms grudgingly. The more you cut them the longer they will flower.

OUR SWEET PEA IIST contains the best sorts of each color, all inferior sorts of similar color and duplicates being discarded. Te thus avoid a long and confusing list. Our selection contains a complete range of colors, from pure white to deepest maroon, every sort being of distinct merit.

Prices: All varieties, pkt. 5c.; oz. 10c.; 1/4 1b. $20 \mathrm{c}$.

Blanche Burpee. Pure white; large, producing three or four flowers on slender, strong stems. Growth vigorous; late but very profuse and continuous bloomer.

Blanche Ferry. Deep pink standards, wings almost pure white. Stems three-flowered, of good length and strength. Blooms abundantly.

Fxtra Early Blanche Ferry. The earliest sort yet introduced. Color and form same as Blanche Ferry.

Captain of the Blues. Nearly true blue. Flowers large; three or four on good stems. Vigorous and free bloomer.

Captivation. Magenta, delicately suffused with purple; of good size and substance, improving as the season advances.

Celestial. Pinkish mauve, turning to azure blue. Stems long and slender, producing three or more flowers each.

Countess of $\Lambda$ berdeen. A very pale pink edged with rose, of good size and form. The best of its color.

Crown Jewel. A beautiful blending. Standards creamy rose, wings a delicate, yet rich creamy blush suffused with a primrose tint; stems long.

Daybreak. Ground white; reverse side of standard watered crimson scarlet; wings white flaked with crimson. A vigorous, upright grower good stem, usually three flowered.

Dnke of Clarence. Deep rose claret. Stems extra long, bearing three or four blooms each. A strong grower.

Miza Eckford. Standards suffused with a delicat rose, wings lightly blushed. Three flowered, sometimes four; long stems.

Fmily zckford. Reddish mauve, approaching blue as it ages. A vigorous grower and good bloomer producing three perfect flowers on extra lons stems.

Emily Henderson. Pure white and of good substance; bears two or three bold, expanded flowers on long, stiff stems.

Firefiy. Brilliant scarlet. A bold flower; stems three-flowered, and of good length; not a tall grower, but flowers well.

cray Friar. General effect gray, with "pepper-andsalt" variegations. Good size and form, strong glower and free bloomer.

Fer Majesty. Large, clear rose-pink; bears three or four well-arranged flowers on long stems. Very uniform and vigorous. A profuse bloomer.

zratherine Tracy. Exquisite soft pink; flower large, perfect and profusely borne; stands hot sun withuut fading.

Lady Beaconsfield. Standards salmon, tinted with rose with a suspicion of purplish pink; wing a pronounced creamy primrose yellow. Blooms profusely.

Iady Nina Balfour. Experts regard this as the most finished of all sweet peas, every flower being a gem. On first opening, it is a rich heliotrope pink. of elegant, expanded form, lapping gracefully inward. Later it takes on a pinkish mauve, the evolution of the tint gradations being in even succession. As it begins to fade it assumes a delicate, clear mauve.

Iottie Zckford. White ground, suffused with heliotrope; edges of both standard and wings a clear heliotrope blue. Fine form, good size, and abundant bloomer.

Mars. Intense crimson. A gorgeous flower, of large size and perfect form. Stems long and slender three or four flowered. A strong grower and liberal bloomer.

Mrs. Fckford. Delicate primrose; most effective when bunched. Stems often four flowered.

when bunched. Stems often four flowered. striped and flaked with deep, clear rose. Form extra fine and large size. Stems extra long and three or four flowered.

Iravy Blue. General color effect dark blue; standards brilliant royal purple; wings pure violet.

A most vigorous grower, and of generous size.

Othello. A very deep maroon; of fine form and size; three flowered. The best dark sort; sometimes called the Black Sweet Pea.

Ramona. Color, creamy white. delicately barred with soft pinkish purple. Large, perfectlyformed and of fine substance.

Senator. A bold, finely-formed flower. Standards white, ground heavily striped with chocolate and some purple. Grows vigorously, bearing an immense amount of bloom.

stanley. Maroon; fine, expanded form and extra large. The most intense dark variety.

Stella Morse. Opens with a fascinating deep cream, becomes a little lighter as the flower grows older. About the third day it is a delicate primiose, with a faint rose-pink on the edge. Perfect form; of the largest grandiflora hooded type. Stems long and three or four fowered. A thrifty, vigorous grower and profuse bloomer.

\section{BUSH SWEET PEAS.}

A new type of Sweet Peas midway in growth between the tall and cupid sorts. Grows less than 2 feet high, producing a perfect mass of bloom at the top of the plant. Pkt. 5c.; oz. 10c.

\section{CUPIDS.}

Distinct as possible from any other sorts; 6 to 12 inches high, but spreading out and forming a mass full $11 / 2$ feet across. Hundreds of stems shoot up, each bearing 3 to 4 flowers, and all in full bloom at once.

White Cupid. The original Cupid. Flowers large and clear white. Pkt. 5c.; oz. 10c.; 1/4 1b. $20 \mathrm{c}$.

Pink Cupid. Blooms are exactly like tall Blanche Ferry. Pkt. 5c.; oz. 10c.; 1/4 lb. $20 \mathrm{c}$.

Cupid irixture. Contains all the new Cupids, and in many respects similar to our Special Mixture of tall varieties. Pkt. $5 \mathrm{c}$.; oz. $10 \mathrm{c}$; $1 / 4$ 1b. $20 \mathrm{c}$.

\section{SWEET PEA MIXTURES.}

Wood's Special Mixed Sweet Peas. An unsurpassed mixture, made up of named sorts only, all choice, large-flowering sorts of every shade and type, the colors being distributed evenly throughout. For diversity of color, size of flowers, and beautiful forms, this mixture is unexcelled. Pkt. 5c.; oz. 10c.; 1/4 1b. 25 c.; lb. $60 \mathrm{c}$., postpaid.

Mixed Sweet Peas. A good mixture of older varieties, and all colors, but lacks the size of bloom and richness of our Special Mixed. Oz. $5 \mathrm{c}$.; $1 / 4$ lb. $15 \mathrm{c}$.; 1b. $40 \mathrm{c}$., postpaid.

Double Sweet Peas. Have divided or multiplied standards, sometimes 3 and even 4 standards, each as large as in case of single blossom. About 75 per cent. come double. Pkt. 5c.; oz. $10 \mathrm{c}$.

Perennial, or Everlasting Sweet Peas. When once sown, these come up vear after year Colors, red, white, and blue. Pkt. 5c.; oz. $50 \mathrm{c}$.

\section{SUNFLOWER.}

Luxuriant plants for centres of beds or background for other plants. H. A

"Stella." A miniature Sunflower covered with hundreds of small, bright orange, single flow ers. Of dwarf pyramidal growth. Fine for bedding and cutting. Oz. 25c., .......... 5

Double stella. A double form of miniature sunflower, bearing a profusion of golden yellow flowers on long stems. Fine for decorating. 10

Double Californian. Double yellow variety, growing 3 to 5 feet high. Oz. $15 \mathrm{c}$., ....... ers, producing immense single heads. Oz. 10c., 5 


\section{SWEET WILLIAM.}

Pkt.

Beautiful free-flowering plants of extreme richness and diversity of color. Produces a fine effect in beds or mixed

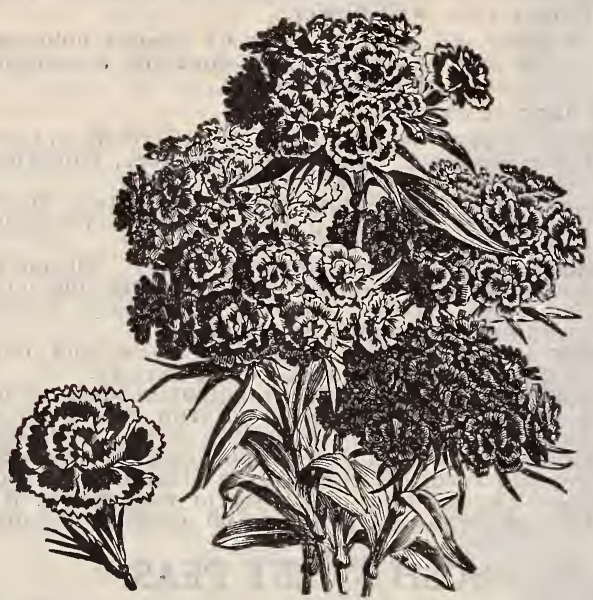

Double Sweet William.

Single. Many bright colors mixed. Oz. 25c., .. 5 Double. All colors mixed. $1 / 2$ oz. $20 \mathrm{c} ., \ldots . . .5$

\section{TEN WEEKS STOCKS.}

(Gilliflower). All varieties are desirable for bedding or pot culture. Bear an immense quantity of fragrant blooms, each plant forming a perfect bouquet; and are splendid for cutting. H. H. A.-1-2.

Giant Pyramidal Perfection. A magnificent race with immense spikes of perfectly double flowers, often 2 to $2 \frac{1}{2}$ inches across. Height, $2 \frac{1}{2}$ feet. Mixed colors, $1 / 8 \cdot$ oz. 50 c., ..........10

Dwarf Iarge Flowering Double. A splendid strain for pots and beds. The blossoms are unusually large, perfectly double and of many beautiful colors. $1 / 8$ oz. $40 \mathrm{c}$, . ............. mous size and extra fine for cutting about 1 foot high, throwing outside branches, each bearing fine, rosette-shaped double flowers, which the oftener they are cut the better they seem to like it. Mixed colors, .....10

Dwarf German Mixed. A fine type of large flowering stocks, of many well selected

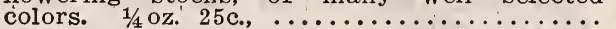

SMIrAX. A charming, tender perennial climber for greenhouse or window garden. Used very extensively for decoration and bouquet green Foliage, light green and very graceful. Sow in box in March. Oz. $40 \mathrm{c} ., \ldots \ldots \ldots \ldots \ldots . . .6$

THUXBERGIA, A rapid climber, growing 4 to 6 feet high. Splendid for trellises, fences, etc. bearing beautiful flowers-white, yellow and buff, with black eye-in great profusion. $H$.

TORFNIA. One of the prettiest plants for borders, vases, or hanging baskets. Blooms continually during the summer in open ground, and also in winter in the greenhouse. $T$. A $-2-3$ Height 1 foot.

Fourneri. Blue, with bright yellow throat, ... 5

VINCA, or PERIWINKIE. These make splendid bedding plants for this climate, withstanding heat and drought when other plants suffer. The foliage is very distinct, being of dark rich, glossy green, and the plants bear large pink and white single flowers in greatest abundance. T. P.-2-3. Height, 2 feet.

Rosea. Pink with crimson eye,$\ldots \ldots \ldots \ldots \ldots 5$

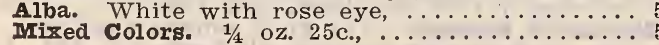

\section{VERBENA.}

Pkt.

Splendid for beds or massing. Flowers of most brilliant colors, blooming from early summer till late fall. Verbenas grown from seed are always thrifty, and do not rust. Sow early in house, or out of doors in April. H. H. P.$1-3$.

Mammoth Mixed Colors. This strain produces blooms of largest size and most brilliant colors. The trusses are uniform, bearing unusually large flowers in a wide range of colors. 1/4 oz. 35c.; oz. $\$ 1.25, \ldots \ldots \ldots \ldots \ldots \ldots \ldots \ldots$ Defiance. Brilliant rich scarlet. $1 / 4$ oz. 30 c.; oz.

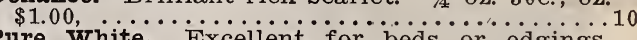

Pure white. Excellent for beds or edgings.

Mixed Colors. "A splendid mixture from named sorts, comprising rich, beautiful colors. 1/4

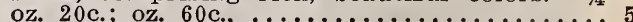

\section{VIOLETS.}

Favorite little plants, producing flowers of most delightful fragrance; popular with every one. Sow in beds, and transplant.

Blue or white. Separate colors, each, .......10

Mixed Colors. Sweet scented. $1 / 4$ oz. $40 \mathrm{c} ., \ldots \ldots 10$

VIRGINIAN STOCK. Beautiful, free flowering annuals, desirable for beds, baskets, or edgings; succeeds well in any soil. H. A.-1-2. Mixed colors, .....................

\section{WALLFLOWER.}

Well-known, hardy plants, producing fragrant flowers of various colors. Blooms eariy in the season. H. P.-1. Height, $1 \frac{1 / 2}{2}$ feet.

Single. Mixed colors. Oz. $25 \mathrm{c}$., ............

Double. Mixed colors, .....................

\section{ZINNIAS.}

For gorgeous summer and fall display the Zinnia is unsurpassed. The flowers are perfectly double, resembling Dahlias, and almost every shade of color. For bedding and massing, they are particularly suitable. H. A.-2-3.

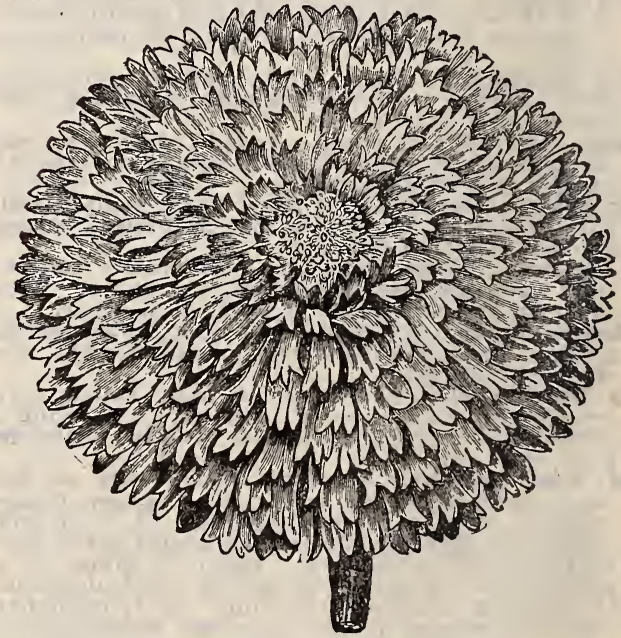

Double Fringed Zinnia.

Double Fringed. Perfect flowers with more or less deeply cut or laciniated petals. New and

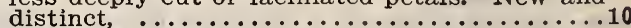

Curled and crested. " $A$ new strain of fantastically shaped flowers, with twisted petals, $\ldots 10$ Tom Thumb. Very dwarf; excellent for beds and borders. Flowers double and of very

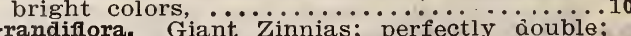
flowers of finest brilliant colors. Oz. 40c., ...10 Double Striped or Zebra. A profuse bearer of finely double flowers in many colors, .....10

Double Mixed. A fine mixture of the best tall Zinnias; all colors mixed. Oz. $30 \mathrm{c}$. ......... 


\section{ROSES. Out-Door-Grown Plants.}

Plant our ..... Out-Door Grown ROSES

In February or March and have a magnificent sup. ply of flowers all the season.

We can furnish our out-door-grown Roses in a dormant condition any time previous to the first of April. Our out-door-grown stock are the best and most satisfactory roses to plant, and will produce a magnificent supply of flowers the same season they are set out. They are larger, stronger and better rooted plants, thrive better, and give much better results in every way than plants started and grown in green-houses, as usually sold. Our list includes the best varieties in cultivation.

Don't overlook the fact that it is much better to plant these out-door-grown roses in February or March, before they have commenced to grow, than at any other time. Price, 25c. each; $\$ \mathbf{2 . 5 0}$ per dozen. The varieties we can supply are as follows:

\section{HYBRID PERPETUAT ROSES.}

Gen. Jacqueminot. Crimson; fine.

Paul Neron. Large flowers; pink.

Alf. Colomb. Cherry red; splendid.

Magna Charta. Beautiful dark pink.

Coquette des Alpes. Pure white; free bloomer.

Margaret Dickson. Fine, pure waxy white.

Anna De Diesbach. Brilliant carmine; fine flowers.

Victor Verdier. Rosy carmine; large flowers.

Prince Camelle de Rohan. Deep rich velvety crimson.

American Beauty. Large flowers; rich rosy crimson. Caroline Testout. An exquisite free blooming pink rose.

BOURBON AND CHINA ROSFS.

Very desirable free blooming hardy roses.

Hermosa. Deep pink; very profuse bloomer.

Aggripina. Brilliant red, showy and sweet.

FVERBLOOMING TEA ON IMONTELY ROSES.

Itoile de Iyyon. Rich golden yellow, very desirable. Safrano. Orange yellow, tinted with rose.

Catherine Mermet. Beautiful pink; a splendid rose. White I Iaman Cochet, Finest out-door tea roses; Pink Maman Cochet, $\}$ beautiful buds and flowers. Kaiserin Augusta victoria. White; fine buds and flowers.

The Bride. Lovely pure white.

Clothilde Soupert. Color ivory white, shaded with rose; beautiful and remarkably free bloomer.
Sunset. The queen of Yellow Roses. Color rich amber yellow.

Bridesmaid. Color fine clear dark pink; fine buds. White Ia France. Free bloomer; pure white, with rose tint.

I France. Light silvery pink, delicious fragrance. Miseteor. Rich velvety crimson; makes fine cut flow-

Perle tiful.

\section{CIIMBING ILOSES}

Reine Marie Fienriette. Cherry red; beautiful climber.

Red Marchal Niel. Hardy; fine red flowers.

Glorie de Dijon. Color rich creamy white; not entirely hardy.

White Rambler. Beautiful white climber; free foliage.

Crimson Rambler. Bears clusters of crimson flowers.

Yellow Rambler. Earlier than the crimson; splendid. Pink Rambler. Vigorous growing; fine foliage.

Helene. Bears magnificent clusters of violet crim son flowers, larger than Crimson Rambler.

Dorothy Perkins. A beautiful new climbing rose. WICEURIANA, OT MEMOIRIAI ROSES.

Evergreen Gem. Buff yellow, delicious sweet briar fragrance; fine foliage.

Jersey Beauty. Large yellow flowers, produced in clusters.

Price of all varieties, 25c. each; $\$ 2.50$ per dozen.

\section{GENERAL RULES FOR FLOWER CULTURE.}

The Soil best suited to flowers is a light rich loam, which should be as fine and smooth as possible. Should the soil be heavy, mix with sand to lighten and make it friable.

Sow the Seed either broadcast or in rows, and cover lightly-a good general rule is to cover two or three times the size of the seed-and press the soil firmly. Small seeds cannot come up if covered too deep. Some sorts should be started in the house, either in seed-boxes, earthenware pans or flower pots. Water with a fine spray, and do not allow the soil to dry out, but be careful not to keep young plants continually saturated, as they will be liable to damp off. When three or four leaves have formed transplant one inch apart in boxes, or into the open ground if warm enough.

\section{CULTURAL INFORMATION AND ABBREVIATIONS.}

Read carefully, that a proper selection may be made for a succession of flowers throughout the season.

Figures 1, 2, 3, indicate the blooming season, viz.: 1, early summer; 2 , about mid-summer; 3 , late summer and fall. Where the blooming season extends, two figures are used, viz.: 1-3, from early summer till fall.

A.-Annual. Flowers, seeds and dies the first season. Sometimes come up year after year from self-sown seed.

B.-Biennial. Lasts two years. Usually blooms second season.

P.-Perennial. Lasts three or more years; blooms annually after first year.

H.-Hardy. Hardy annuals (H. A.) can be sown in open border in March or April, thinning out or transplanting as necessary Hardy Biennials (H. B.) and Perennials (H. P.) can also be sown (H. B.) and Perennials (H. P.) can also be soll. at this time or later in the summer or fall. they usually bloom the first season.
H. H.-Half-hardy Annuals (ㅍ. H. A.), Biennials (H. H. B.), and Perennials (H. H. P.), require a longer time to establish themselves, and being more tender when young, should, if to bloom early, be started in the house or hot-bed. Can be sown outside the last of April or first of May. Most H. H. B. and H. H. P. started in the house bloom the first season.

T.-Tender Annuals (T. A.), Biennials (T. B.), or Perennials (T. P.) treat same as H. H. Annuals, but with more caution as to exposure, removing outside only when the weather is settled and warm. Calceolarias, Cinerarias, Cyclamen, Gloxinias, Primulas and Smilax should be kept in pots, shifting to larger sizes as the growth requires.

Seeds with horny shell, like Canna, Evening Glory Brazilian and Japanese Morning Glories, should have a small hole filed through the outer shell, or soaked in warm water thirty-six hours before planting. 


\section{SUMMER FLOWERING BULBS.}

\section{CANNAS.}

Dwarf French Cannas grow about three feet high are excellent for bedding and massing. Their pyramids of bright flowers are very attractive during the summer and fall months. Should our stock of any sort be sold out, we will substitute one most closely resembling the variety ordered.

Austria. Flowers 6 to 7 inches across; five petalled, three pure yellow and two slightly spotted carmine.

Allemania. Upper petals scarlet with broad yellow border.

Alphonse Bouvier. Tall crimson; very floriferous, Alsace. The white Canna. Pale sulphur yellow upon opening, changing to pure white.

Alba Rosa. Rich rose at base, tinting into creamy white.

Chas. Henderson. Very large; brilliant red.

Florence Vaughan. Rich yellow, spotted with bright red.

Gloire Iyonnaise. Canary yellow, mottled crimson.

Italia. Flowers 6 to 8 inches across; rich flaming scarlet with broad yellow border.

Mad. Crozy. Crimson scarlet bordered with yellow. Queen Charlotte. Crimson banded with canary yellow.

Rose Unique. Beautiful rose color; a vigorous grower.

Price, 15c. each; $\$ 1.25$ per dozen. If by mail, add 5c. each for postage.

Mixed Cannas. Named sorts from which labels have become detached; equally as good as the above. All colors, 10c. each; 80c. per dozen.

\section{CALADIUM. (Elephant's Ears.)}

Caladium Fsculentum. A most effective plant for planting upon lawns and in groups. Of easy culture, but require good soil and plenty of water. Extra large bulb, 15c. each; $\$ 1.50$ per dozen: Medium size bulb, 10c. each; $\$ 1.00$ per dozen. Postage extra; large bulb, 8c.; medium, $5 \mathrm{c}$.

Fancy Ieaved Caladiums. May be grown either in greenhouse, window-boxes, or out of doors, making elegant decorative plants. Plant when ground has become warm in a partly shaded situation in well-enriched soil. 25c. each; $\$ 2.25$ per dozen. Postage paid.

\section{DAHLIAS.}

Our list of "show dahlias" includes a wide range of colors, from the lightest to the darkest shades, all improved sorts, from which a gorgeous display may be had. Should our stock of any sort be sold out, we will substitute one resembling most closely the variet" ordered.

15c. each; $\$ 1.25$ per dozen. If by mail, add 5c. each for postage.

A. D. Iivoni. La France rose color; free bloomer. American rlag. White and red striped.

Arabella. Yellow tipped with pink and purple.

Bird of Passage. Rose shaded with pink.

Crimson King. Fine large crimson; free bloomer.

Clifford W. Bruton. A splendid yellow cactus sort; flowers 4 inches across.

Dandy. Very dark rich maroon.

Flectric. Large dazzling crimson scarlet; single

Grand Dake Alexis. Ivory white shaded with pink quilled.
Fashion. Crimson maroon flamed purple; single.

Henry Patrick. Pure white cactus dahlia.

Fing of Cactus. Fine crimson maroon.

Miss Mary Iomas. Pure white, suffused with delicate rose.

Nymphae. "Water Lily Dahlia." Clear bright pink, shading darker toward the outer petals; large flower.

Oriental. Bright salmon; single.

Purity. Fine large pure white.

Queen of Yellows. Fine pure yellow.

Queen Victoria. Large bright yellow; deeply quilled.

Wm. Agnew. Intense rich dazzling red.

Zulu. The black dahlia; black maroon.

Mised Dahlias. We offer a large assortment of unnamed sorts, comprising every conceivable color and shade. These are first-class in every way, only the colors are not kept separate. 10c. each: $85 \mathrm{c}$. per dozen.

\section{GLADIOLAS.}

One of the most attractive of summer flowering bulbs. Excellent for mixed beds, and produce gorgeous effects if massed in large clumps. For a succession of bloom throughout the summer, plant at intervals from April till June.

Scarlet and Red. 5c. each; doz. 25c.; 100, \$1.75.

White and Iight. $5 \mathrm{c}$. each; doz. $30 \mathrm{c}$.; $100, \$ 2.00$.

Pink Shades. 5c. each; doz. 25c.; 100, $\$ 1.75$.

striped and variegated. 5c. each; doz. 30c.; 100, $\$ 2.25$.

Yellow: 5c. each; doz. 40c.; 100, $\$ 3.00$

Ixtra Iarge Mixed. 5c each; doz, 25c; 100, $\$ 1.75$.

All Colors Mixed. 3 for $10 c$.; doz. 20c.; $100, \$ 1.50$. If by mail, add 10c. per dozen for postage.

\section{MADEIRA VINE ROOTS.}

On account of its very rapid growth and thick shade it affords, this is one of the most popular climbers. Will run twenty feet or more in a season.

5c. each; 30 c. per dozen; $\$ 2.25$ per 100 . If by mail, add 10c. per dozen for postage.

\section{TUBEROSES.}

Prime favorites, and invaluable for bouquets. Tuberoses prefer a strong, rich, warm soil. To ensure perfect development, it requires plenty of heat and water.

Excelsior Pearl. A short, robust variety, producing immense spikes of perfectly double flowers.

Large Bulbs. 5c. each; 25c. doz.; $\$ 1.50$ per 100. Second Size Bulbs. 2 for 5c.; 20c. doz.; 90c. 100.

Albino. A branching single variety, blooming twenty days earlier than other sorts. Each bulb throws up from two to five flower stalks, bearing large flowers of purest waxy white. The petals recurve gracefully, making the flowers resemble some species of Jessamine. The odor is not so heavy as the ordinary Tuberose. 5 c. each; $35 \mathrm{c}$. per doz.

Variegated Ieaved. The leaves of this variety are bordered with creamy white, which gives it an ornamental appearance. Blooms earlier than Excelsior Pearl; has large single flowers of delightful fragrance. $5 \mathrm{c}$. each; $35 \mathrm{c}$. per doz.

If by mail, add 10c. per dozen for postage.

Flower Plant Food. A.concentrated, odorless fertilizer prepared especially for flowering and Fedding plants, whether grown in pots in the house, or in the open ground. makes the plants grow strong, healthy, and luxuriant; gives the foliage a rich, radiant color, and produces flowers in greater abundance and increased size. A small quantity is required for each plant, and may be worked into the soil around the plant, or applied in solution. Perfectly clean and free from noxious odor characteristic of most fertilizers. Per package, $25 \mathrm{c}$., postpaid. Dirgctions for applying with each package. 


\section{WOOD'S LAWN GRASS SEED.}

\section{Wood's Evergreen}

\section{Lawn Grass}

will make a beautiful green velvety Lawn six weeks after seed. ing.

Our Lawn Grass Mixtures are specially adapted to our Southern soils and climate. The grasses used in the different mixtures are those which, from careful experiments and practical experience, have been shown to be best adapted for the purposes recommended. For beautiful velvety lawns, where proper care and attention can be given during the summer, Wood's Evergreen Lawn Grass is the best that can be used; but where care and attention cannot be given during a season of heat and drought, or where the grass is to be sown on light or sandy soils, Wood's Drought-Resisting Lawn Mixture will give best results. For large lawns, where a combination of both lawn and grazing is desired, Wood's Permanent Lawn Grass is to be especially recommended.

We have issued a special ci:cular about the preparation, seeding and care of lawns, which we will take pleasure in mailing free of charge to any one requesting it.

\section{WOOD'S EVERGREEN LAWN GRASS.}

This will form a rich, deep green, velvety lawn in a few weeks' time. It is composed of various zrasses that grow and flourish during different months of the year, so that, with proper care and attention, a beautiful green lawn can be kept all the year round. The grassas used are those which years of oxperience have shown to succeed and do best in our Southern soils and climate. Sow at the rate of 60 to 75 lbs. per acre, or for small yards one quart to 300 square feet. Price, per quart, $25 \mathrm{c}$.; if sent by mail, 30 c.; peck of 5 lbs., $\$ 1.25$; bushel of 20 lbs., $\$ 4.00$; per 100 lbs., $\$ 18.00$.

\section{WOOD'S PERMANENT LAWN GRASS.}

This grass is designed to supply a satisfactory mixture for large places, where a lawn and grazing combined are desired. We have had numerous requests for such a grass for sowing in groves and large fields for lawn and pasturage purposes combined. The grasses of which this is composed are not as ine-growing as those used in our Evergreen. Lawn Grass, but will be very satisfactory where special attention cannot be given to same. Sow at the rate of 40 to 50 lbs. per acre. Price, 25c. per lb.; 5 lbs. for $\$ 1.00$; bushel of 20 lbs., $\$ 3.50$.

\section{WOOD'S DROUGHT-RESISTING LAWN MIX'TURE.}

This lawn mixture is specially put up to resist extremes of heat and drought, which are so often experienced in the Southern States. It will also succeed and do well on light or sandy soils where other lawn mixtures do not succeed. Careful experimenting has convinced us that this mixture will give most satisfactory results, both as a summer and a winter lawn grass, but especially to stand the hot, dry spells in summer, which usually cause lawns to become brown and bare. It is composed of grasses specially adapted to withstand heat and drought, and, at the same time, we have also combined grasses with it which will give a most satisfactory lawn during the fall, winter and spring. Wood's Drought-Resisting Iawn Mixture will, we feel sure, meet a long-felt want. This mixture can be sown in February, March or April; in this section March or April seeding is best. Sow at the rate of one pound to 400 square feet, or 35 to $40 \mathrm{lbs}$. to the acre. Price, 50c. per $1 \mathrm{~b}$; in $10-1 \mathrm{~b}$. lots and over, $45 \mathrm{c}$. per $1 \mathrm{~b}$

\section{WOOD'S LAWN ENRICHER.}

A splendid fertilizer to keep lawns vigorous and in a green, growing condition all through the year One of the principal drawbacks to obtaining and keeping satisfactory lawns is the fact that the nutriment gets exhausted from the surface soil, thus impoverishing the roots of the grass and causing it to die. An application or our Lawn Enricher in the spring and fall will help the grass wonderfully. It is also a good plan to apply it during rainy spells in the summer. The Lawn Enricher is practically odorless, and composed of fertilizing ingredients which, from practical experience, have given the very best results, not only to invigorate the lawn, but to conserve the moisture in the soil, so as to make the grass stand hot, dry weather better. The Lawn Enricher is a complete lawn and grass fertilizer, and the best that can be used when putting down new lawns.

Directions for Using.-In applying this fertilizer scatter as evenly as possible over the surface. It can be applied to lawns at any time except during drought, but the best results can be obtained by using it during the months of September and October and the early spring. For making new lawns it should be applied at the rate of $25 \mathrm{lbs}$. for 1200 square feet, or at the rate of 800 lbs. per acre. As a top-dressing for old lawns, use from 400 to 500 pounds per acre, or for small yards, 5 pounds to each

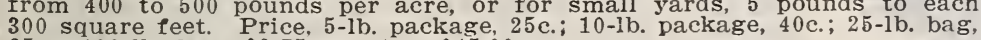
85 c.; $100-1$ b. bag, $\$ 2.75$; per ton, $\$ 45.00$.

WHAT OUR CUSTOMERS SAY ABOUT WOOD'S GRASS SEEDS. "I have never seen such a stand in my life before."

NELSON CO., VA., June 5. 1902.-I sowed your Lawn Grass on April 6 th, and fertilized it with acid phosphate and wood ashes. I have never seen such a stand in my life before. It looked like it had been sown two

Send for our

SPECIAL

\section{LAWN GRASS}

\section{CIRCULAR,}

telling about prepara= tion, seeding, and care of Lawns, etc.

Mailed free on request.

"Best piece of sod in the South-A good advertisement of your house."

STINNANOA COUNTRY CLUB, ASHEVILLE, N. C., Nov. 11, 1902.-I wish to take this opportunity f letting three years ago on the Golf Course of the Swannanoa Country Club. I believe it is the best piece of sod in the South. It is a good advertisement of your house, and I take pleasure in recommending this seed, every opportunity I have.

"The finest stand you ever saw."

IREDELL CO., N. C., Oct. 27, 1902.-I want to say that the Mixture No. 6 that Mr. Gill ordered for me one year ago has made the finest stand you ever saw. Also the same mixture of grass he obdered this fall is looking fine. 


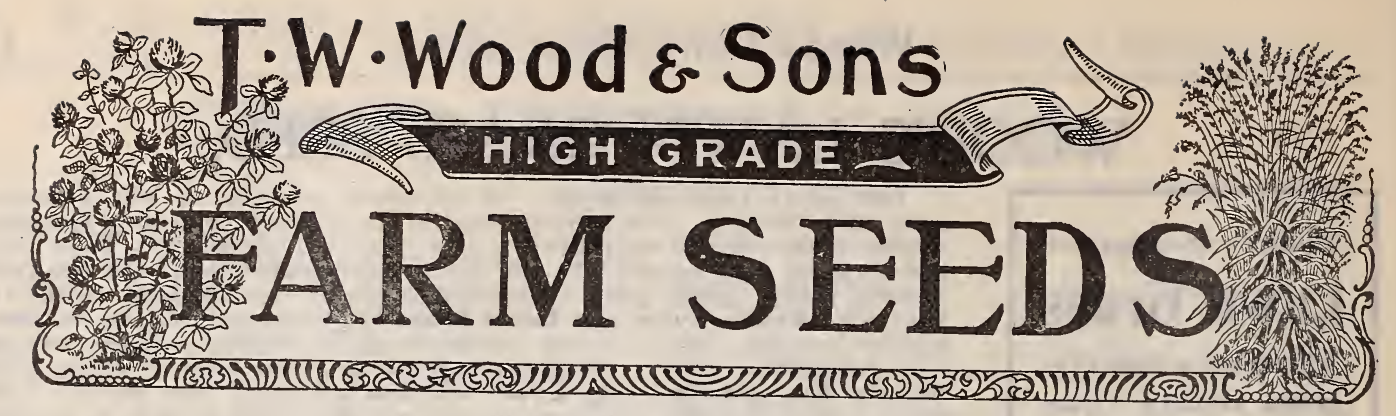

Our trade in Farm Seeds is one of the largest in this country. The steady increase which we have experienced in this line year after year is the best of evidence as to the high quality of the seeds supplied by us. Our knowledge of the seed business, facilities for growing and securing the very best stocks, together with our large warehouse capacity, enable us to supply the very best seeds at as reasonable prices as it is possible for first-class seeds to be sold.

PRICES OF FARM SEEDS FLUCTUATE. Prices of Grass and Clover Seeds, Seed Grain, Seed Potatoes and other Field Seeds are constantly fluctuating. The prices given in this catalogue are those ruling at the time it is issued, in August. We will take pleasure at any time in quoting prices on request, or will always fill any orders entrusted to us at as low prices as possible for first-class
seeds.

WOOD'S TRADE-MARK BRAND

of Farm Seeds are the highest grade that can be obtained, and are free from weed seeds and impurities, and of strong germination. This brand is only sent out with our Trade Mark label or brand on each packą. e. Our customers will please note this, and remember that this brand appearing upon a bag, barrel or package unopened, and the seal unbroken, means that it contains the highest grade seeds obtainable. this brand will not be used upon the grades of seeds known as "Choice" and "Prime," which we sell in large quantities. We would also state here that our grades of Choice and Prime, while not quite equal in quality to our Trade Mark Brand, are excellent seeds, and these grades which we sell are not to be compared with the ordinary commercial grades of "Choice" and "Prime" as handled by some dealers, which do not begin to compare in quality or value to these grades supplied by ourselves. There are, of course, lower grades of field seeds than even Choice or Prime handled in the open market, but it is poor economy to purchase low grades of seeds under any circumstances or at any price. Farmers will always find that it is the cheapest and true economy to purchase the highest grade seeds obtainable, and this they can always rely on by purchasing Wood's Trade-Mark Brand.

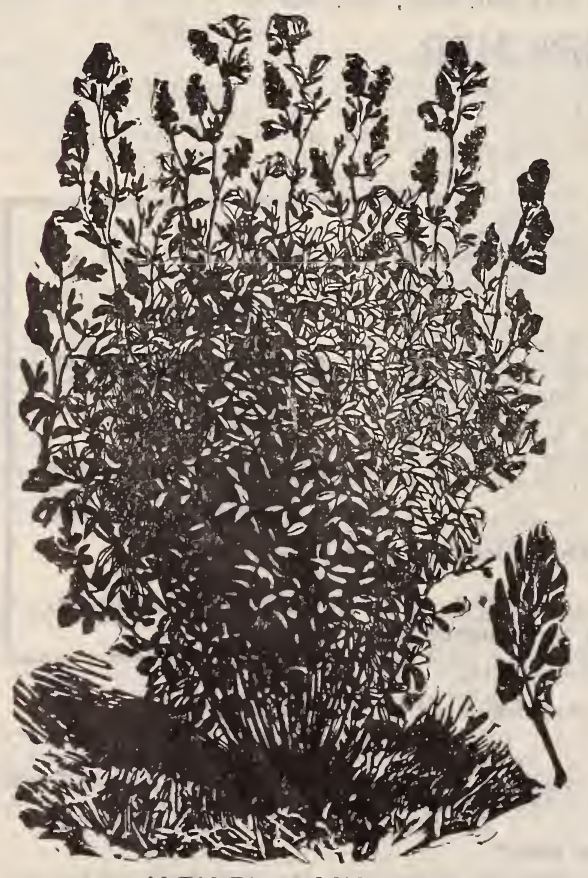

ALFALFA, or LUCERNE.

\section{ALFALFA, or LUCERNE.}

Our Alfalfa seed is new crop American grown seed of the highest quality, and is very much superior in quality, germination and productiveness to Turkestan or any imported Alfalfa seed.

Alfalfa or Lucerne is one of the best crops that the farmer can sow to stand hot summer weather, and for a crop to depend upon during summer droughts. It is also one of the most valuable crops the farmer can grow, whether we get droughts or not, as it will yield four or five cuttings a year of most excellent feed. It grows during dry weather better than any crop we know of. Its beautiful green and growing appearance during droughts, when everything else appears dry and brown, is due to its deep-rooted propensities, and when sown on soils with gravelly or light subsoil, which its roots can penetrate, it will outyield any other grass or clover crop when it once gets well established. A good firm seed bed is necessary in order to get a good stand of Alfalfa, and the ground should be ploughed some time previous to seeding, and narrowed and cross-harrowed several times so as to give a good preparation. Some farmers recommend the seeding on wheat or oat stubble land, simply preparing the land by running the cutaway, disc or sharp-toothed harrow over it before seeding. The seed should be sown either broadsown either in spring or fall. March or April are the best months in the spring.

After Alfalfa is once well established, it will last for a number of years. Price of our Trade-Mark Brand Alfalfa, which is new, strong-germinating seed, 15c. per lb.; $\$ 8.00$ per businel of 60 pounds

\section{CRIMSON, OY SCARIET CIOVER.}

Recommended for fall seeding only in this section, although spring seedings do fairly well in some sections of the country. Full information in our Fall Catalogue, issued in August, which will be mailed free upon request. Price, 8c. per 1b.; about $\$ 3.50$ per bushel. 


\section{WOOD'S RECLEANED CLOVER SEED.}

\section{RED CLOVER. (Trifolium Pratense,)}

One of the most valuable farm crops, and is largely usea for pasturage and hay and as an improver of the soil Red Clover on good land will yield two or three cuttings per year. The first crop makes rich feed, and is the most valuable for hay. The second crop does not make so good a quality feed. Like other leguminous plants, Red Clover draws largely tor its sustenance from the atmosphere gathering nitrosen and other constituents required by cultivated crops; its roots penetrate deeply, drawing from the subsoil, thus actiing as a soil improver, and not only increasing the procuctiveness of the land, but putting it in better condition than before. In some sections of the South it is the custom, where tobacco and cotton are be rastly better if, instead of leaving these lands unoccupied. they were sown in Red Clover. In this way farmers pied, they were sown in Red clover. In this way farme be would not only get a crop of forage, but the land would be Clover, intelligently used, is the farmer's best friend, not only furnishing most nutritious feed, but restoring fertility to worn-out lands. It is strongly to be recommended, however, that clover be used in a rotation of crops and not grown successively on the same fields. A top dressing of 200 pounds of land plaster to the acre on top dressing of 200 pounds of land plaster to the acre on clover in the spring improves the growth wonderfuly. sown either in the fall or spring. March and April are the best months for seeding clover in the spring. When sown by itself sow 10 to 12 pounds per acre. Sown with Orchard Grass, 6 or 7 pounds of clover with one-and-ahalf bushels of Orchard Grass per acre will give a liberal seeding. Price of our Trade-Mark Brand Red Clover Seed. seeding. Price of our Trade-MLark Brand Red Clover Seed, choicest and cleanest quality, about $\$ 7.00$ per bushel. ates. Will quote prices at any time upon request

\section{MAMMOTH, or SAPLING CLOVER. (Trifolium Pratense.)}

This is a selection of the Red Clover, and is similar to it both in the appearance of the seed and its habits of growth, the difference being that it usually grows larger, and is later in maturing. It is considered superior as an improver on account of the extra growth. It is a good variety for thin soils, or to seed with Timothy, as it matures about the same time. The appearance of the seed of this is identical with the Red Clover, and on this account it is impossible to distinguish any difference between the two by the appearance of the seed. We always obtain our supplies from reliable sources, but in this, as in all other seeds, we give no warranty in any way, simply using every reasonable care to supply Mammoth, or Sapling Clover as ordered. Sow ten to twelve pounds per acre by itself, or with Timothy six pounds of Clover and eight pounds of Timothy will give a liberal seeding. Price fluctuates. Present price (January 1st) for our Trade-Mark Brand is $\$ 7.25$ per bushel. Choice quality seed, about $\$ 7.00$ per bushel.

\section{ALSIKE CIOVIR. (Trifolium Hybriaum.)}

Makes a good pasturage on stiff, moist soils, but its chief value is for hay. It will stand any amount of cold, but does not like too much heat, hence it is more suited to the alluvial valleys of our mountains than to the coast region of the Southern and Southwestern States. As Alsike Clover flowers later than Red Clover, it is more suitable to sow with Timothy Price of Trade-Mark Brand seed, per lb., $20 \mathrm{c}$.; ku. about $\$ 10.00$.

WHITE CLOVER. (Trifolium Repens.)

This variety does well in almost any kind of soil, but prefers moist situations. It will thrive better on land containing iron than any other kind of clover. It is largely used in lawn and pasturage mixtures. Sow either in the spring or fall at the rate of five or six pounds per acre. Price, $30 \mathrm{c}$. per lb. Bushel prices on application.

JAPAN CIOVIR. (Iespedeza Scriata.)

Prof. F. A. Gulley, of Mississippi, says of this plant: "For the South, Japan Clover is. without exception, the most valuable plant that grows. After once started, it grows spontaneously, except on lime land. It keeps hills from washing, even coming in to fill the washes." Experience with this forage plant in Virginia confirms its value for the poorer soils of this and other Southern States. In places where it was sown several years ago it is found spreading all over the neighborhood, along the roadsides, ditch banks, and over neglected fields; at the same time it is easily subdued by cultivation, and does not in any way prove a pest to cultivated crops. It is chiefly recommended for grazing purposes, although in the far South it yields good crops of hay. It will succeed if sown broadcast on old pastures, broom-sedge, etc.. without any preparation, and will soon spread and grow thickly all over the fields where rut in, even taking the place and driving out broom-sedge and wire grass. It is best not to graze it too early the first season, so as to give the seed time to mature and fall, which it is constantly doing all summer from season, so as to give the seed time to mature and fall, which it is constantly doing all summer this clover for land that can be successfully grown in other grasses or clover, but on waste land or this clover for land that can be successfully grown in other grasses or clover, but on waste land or
poor, worn-out soils it will furnish excellent nutritious pasturage. Sow at the rate of ten pounds per acre, in March or April. It does not make much showing the first year the seed is sown. Per lb. 25c.; bushel of 25 lbs., $\$ 5.00$.

AIFAIFA, or IUCERNE. For full information, see page 56.

WHITE BLOOMING CRIMSON CLOVER.

Two to three weeks later than the Early Crimson, and makes larger growth. For fall seeding only. Price, 10c. lb.; $\$ 5.00$ per bushel.

BURR CLOVER.

Recommended for fall seeding only. Full information see in our Fall Catalogue. Price, 1b. 30 c.; $\$ 2.50$ per bushel (10 lbs.). 


\section{WOOD'S HIGH GRADE GRASS SEEDS.}

The Grasses and Clovers are the Surest Basis for Permanent Prosperity on the Farm, and the Best and Surest Method of Resting und Improving Land.

WOOD'S GRASS AND CIOVIR SFIDS have attained the highest reputation for purity, cleanliness, and germinating qualities, causing our business in same to become one of the largest in the country. Selling these seeds in the large quantities that we do, also enables us to supply same at the lowest possible
prices for the best quality seeds.

The description and information that we give in our catalogue is especially full and complete. The description of the different varieties, the suggestive combinations with other kinds, the adaptability for various soils and conditions, with other information, will be found of especial use and value in arriving at correct conclusions as to the best varieties of grasses to use for the purposes which are desired to be btained.

\section{BIST METHODS OF PRFPARATION AND SFPDING OF GRASS SFEDS.}

We have issued a special Grass Seed Circular giving full information as to the soils adapted to the different grasses; time of seeding; preparation of soils; adaptability of the different grasses to various soils and conditions; care of pasture and meadows, with much other useful and valuable information to all interested in grass culture. We will take pleasure in niailing this circular to any one interested upon request. Do not hesitate to write for it, or any other special information desired. We cheerfully answer all correspondence.

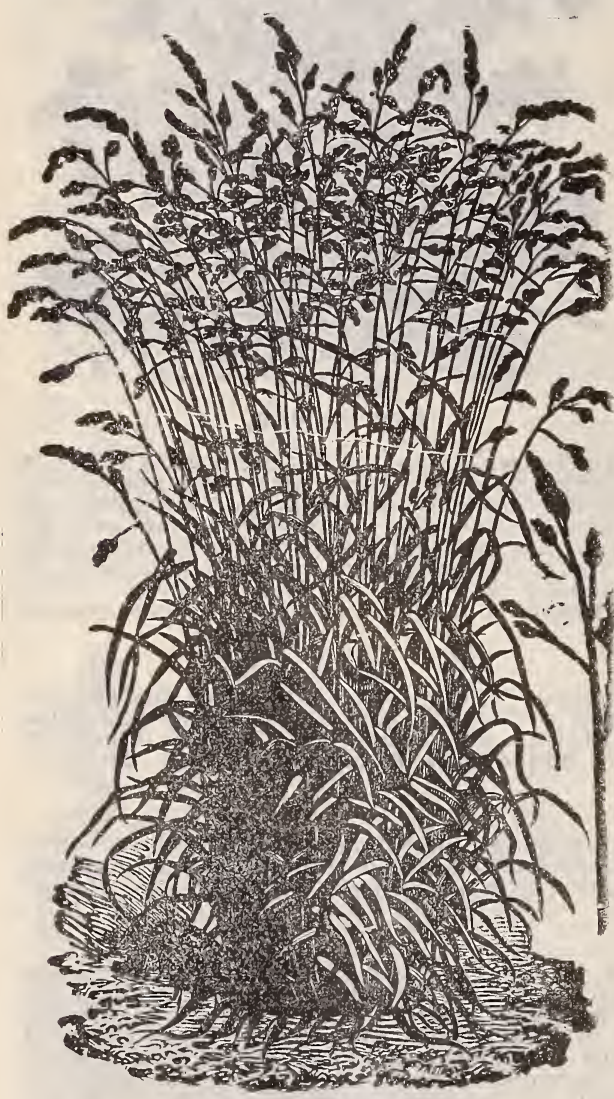

ORCHARD GRASS.

One of the most valuable hay pasturage grasses for this section. Does well on neariy all soils.

\section{TALL MEADOW OAT GRASS.}

One of the most valuable hay pasturage grasses in cultivation, and especially desirable and adaptable to the South. It withstands the heat and drought of midsummer and cold of winter, starts very early in the spring, and continues to give good grazing until late in the fall. For hay, it can be cut twice in a season, and will yield nearly double as much as Timothy. Its nutritive qualities are first-class, containing, by anaiysis, more flesh and muscle-forming materials than Timothy, but is not quite so fattening as that grass. It ripens at the same time as Orchard Grass, and gives the very best results sown with it and Red Clover. For hay, it should be cut while in bloom. Tall Meadow Oat Grass is best adapted for good loamy uplands, but gives excellent results on nearly all soils, and better results than any other grassoon light, medium, or sandy soils. Farmers who have been sowing this grass for years are especially well pleased with the returns from it, and are sowing constantiy increasing acreages each year. When sown by itself, sow at the rate of two to three bushels per acre, either in the spring or fall. Sown with Orchard Grass and Red Clover, the quantities usually sown ar one bushel (11 lbs.) Tall Meadow Oat Grass, one bushel (14 lbs.) Orchard Grass, and 6 pounds Red Clover. The addition of 4 pounds Fancy Clean Red Top or Herd's Grass seed to the acre to this mixture increases the aftermath and the yield of grazing. This combination is excellent, and one that has given the most satisfactory results. Tall Meadow Oat Grass seed is short crop, and higher in price than usual this season. Price, per lb. 20c.; Trade-Mark Brand seed, $\$ 2.00$ per bushel; choice seed, $\$ 1.90$ per bushel. Price fluctuates. Will quote existing prices on request at any time.

\section{ORCHARD GRASS. (Dactylis Glomerata.)}

One of the best and most reliable grasses for the Middle and Southern States, either for hay or pasturage. It succeeds well on nearly all soils, but does vest on upland, loamy, or moderately stiff soils. It starts early in the spring and continues well into winte? It is of quick growth and relished by stock, especially w'len young, and bears close grazing. It makes excellent hay, and gives the very best results mixed and grown with Tall Meadow Oat Grass and Red Clover, as suggested under the head of Tall Meadow Oat Grass. It should be cut when in blossom, as the hay is injured if the seed is allowed to ripen. It can be sown in the spring or fall, either with grain, or alone Sow two bushels per acre if sown alone, or with Red Clover, one and a half bushels of Orchard Grass and seven pounds of Clover, are the quantities usually sown. Price liuctuates. Present price of our Trade-Mark Brand, per lb. $15 \mathrm{c}$; bu. of 14 Ibs. $\$ 2.00$; choice seed, $\$ 1.90$ per bu. We will quote prices at any time upon request.

\section{KEINTUCKY BLUE GRASS. (Poa Pratensis.)}

An exceilent pasturage and lawn grass, succeeding best on limestone land, but does well on stiff or clay and medium soils. It is rather sensitive to heat, but not so to cold weather, and on this account does its best in the fall, winter and spring. It grows slowly at first, forms a very compact turf, making a fine pasturage when once established. It is best, however, to combine other grasses with it for either lawn or pasturage. Sow in the fall or spring at the rate of two to three bushels per acre. Fancy Clean seed, per lb., 20c.; per bushel of 14 pounds, $\$ 1.60$. Special prices in quantity.

ROWAN CO., N. C., Oct. 14, 1902.-The rye, clover and vetch seeds I bought are up and growing fine You ought to see them. I am convinced that it pays to buy Wood's Seeds. I expect to buy all my seed
potatoes and other seeds direct from you.

AMHERST CO., VA., Jan. 1, 1902.-I have been buying your seeds through our local merchants for a number of years, and find them first-class. They are all you claim for them. 


\section{MEADOW FESCUE, RANDALL, or ENGLISH BLUE GRASS, (Festuca Pratensis.)}

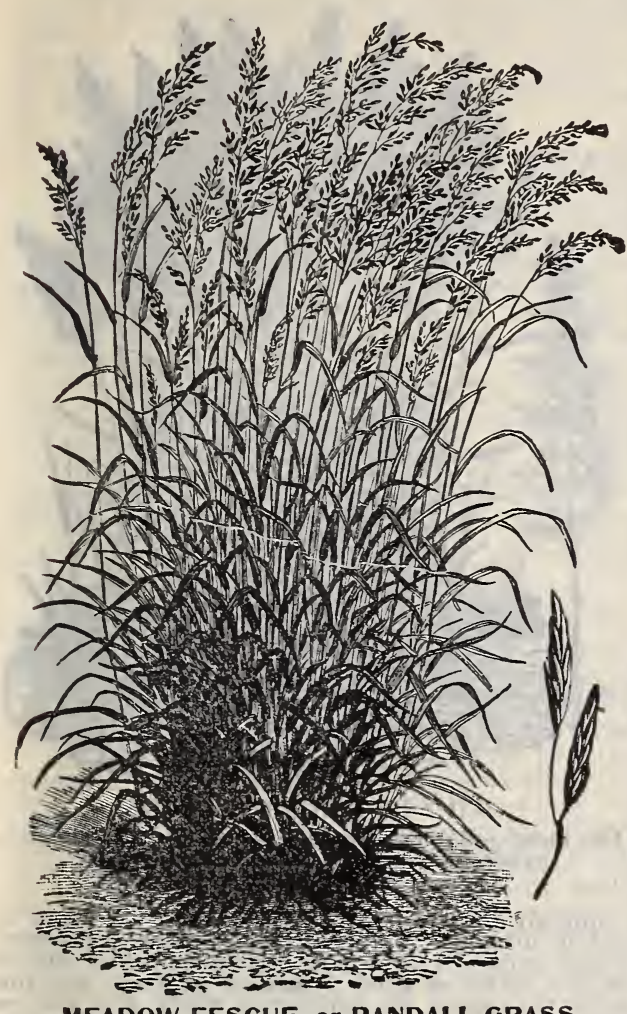

MEADOW FESCUE, or RANDALL GRASS.

This should be very much more largely used than at present. It makes a most excellent hay and pasture grass, and is particularly valuable for fall and winter pasturage, as it remains green throughout the winter. It is also a splendid spring and summer grass, and usually makes more and thicker leafage than any grass we have grown. It is very popular in Southwest Virginia, East Tennessee and the mountainous districts of North Carolina, where it is very highly appreciated as a large-yielding, nutritious pasturage and hay grass. It succeeds well in nearly all sections of the South, and should be very largely used in pasturage and hay mixtures, being specially suitable for sowing with Red Top and Timothy for hay, or with these and Orchard and Tall Meadow Oat for permanent pasturage. Sow either in the spring or fall at the rate of two bushels to the acre, if sown by itself. Price of our Trade-Mark

\section{TIMOTHY. (Phleum Pratense.)}

This makes one of the most popular, nutritious and salable of hay grasses. It is best adapted for sowing on clay or heavy loams, low lands or in mountainous districts, although it will do well on any good stiff, loamy soils, provided moisture is abundant. It does not succeed nearly as well, however, as Orchard, Tall Meadow Oat or Herd's Grass on soils of a sandy or light loamy texture, and is not of as much value for pasturage as other grasses. The stand of Timothy will also be injured if grazed or cut too closely. The yield of hay on good ground is from one and a half to three tons per acre. The best clover to sow with Timothy is either the Sapling or Alsike as they mature and ripen with Timothy. The practice of sowing the common Red Clover with Timothy is not advisable, as they do not ripen together, the clover being ready two or three weeks before the Timothy; thus either one or the other must be cut at a stage which will not give best results. Red Top or Flerd's Grass and Meadow Fescue mature at the same time as Timothy, and are excellent grasses to sow with it both for hay and pasture. They will increase the yield of hoth to a certain extent, but will very largely increase the yield and value of the pasturage. Timothy by itself requires to be sown at the rate of about a peck (11 pounds) to the acre, or with clover, 8 pounds of Timothy and 6 pounds of clover will give a good seeding. A mixture of Timothy, Red Top. Meadow Fescue and clover should be sown in the following proportions: Six pounds Timothy, four pounds clover, four pounds Fancy Red Top, one-hal bushel Meadow Fescue. These will furnish an excellent mixture, both for hay and pasturage, on good loamy, clay or low ground soils. Present price of our TradeMark Brand: Per Ib. 8c.; per bushel, \$2.25. Price fluctuates.

PERTRMIAI RYE GRASS. (Iolium Perene.)

A quick-growing, very early-maturing grass, best adapted to strong, rich, moist clay soils, on which soils it will last several years. It furnishes good grazing and hay, but as it does not root yery deeply, does not stand drought so well as some other grasses; does. very well in mixture with grasses like Orchard and Tall Meadow Oat. This grass is also quite largely used as a lawn grass in the South in connection with Bermul Grass, being sown on the scarified Bermuda sod in the fall, furnishing a quick growing and most excellent green sod all through the winter and spring until crowded out by the Bermuda the following summer. When sown by itself, sow thirty pounds per acre in spring or fall. Per lb. 12c.; bu. of 14 lbs., about $\$ 1.00$.

\section{ITAIIAN RYI GRASS. (Iohum Italicum.)}

Recommended principally for fall seeding. Yields three or four cuttings per year of most nutritious hay; very valuable grass. Full description in our Fall Catalogue, which will be mailed upon request. Price, per lb., 12c.; $\$ 1.10$ per bushel of 14 pounds.

\section{POA COMPRESSA. (Also called Native and Canada Blue Grass.)}

Is very highly recommended by some authorities on grasses, both as a lawn and pasturage grass in the South. Our own experience with it has not been uniformly satisfactory, and, while it may give good results in mixtures, we would recommend to our customers, in sections where it is untried and unknown, to experiment with it on a small scale before sowing it extensively. Per 1b., 15c.; bushel of 14 lbs., $\$ 1.25$.

\section{CEESTID DOG'S TAIX.}

A valuable pasturage grass, largely used in mixtures recommended for dry soils and situations. Does well on hill-sides. (See "Special Mixtures," page 63.) Per lb., 40c.

\section{CREEPING BENT GRASS. (Agrostis stolonifera.)}

This grass somewhat resembles the Red Top or Herd's Grass in growth and appearance, and is considered by many practical men as fully equal, or even superior, to that grass. It is certainly a splendid grass and well adapted for the South, and should be largely used in all lawn and pasturage mixtures. (See "Special Mixtures," pages 62,63.) It has creeping or stoloniferous roots, and spreads and holds to the soil in a very tenacious way. Per 1b. 25c.; $10 \mathrm{lbs}$. and over, 20c. $1 \mathrm{~b}$.

\section{RFPD CATARY GRASS. (Phalaris Arundinacia.)}

"A tall, leafy perennial, little affected either by drought or cold, and thrives well in the shade. It succeeds best on stiff, wet lands and on wet, floody fields, and will grow fairly well upon rather dry, sandy soil. The root stocks are very strong and creep extensively, making this grass particularly valuable for binding banks of rivers and ditches where the water supply is ample. It does not attain its full size until the second year, and if designed for hay, should be cut before flowering." Price of seed, $50 \mathrm{c}$. per lb. 


\section{RED TOP, or HERD'S GRASS. (Agrostis Vulgaris.)}

This grass makes excellent pasturage and good crop of fine quality hay, and succeeds on a greater variety of soils than any other grass in general use, giving very good results on light soils, and the very best results on heavier, moist, or low ground soils. It is rather late in starting in the spring, and matures its crop at the same time as Timothy. Is excellently adapted for seeding with Timothy for hay, and furnishes excellent pasturage afterwards. When it gets well established it spreads, and will gradually supplant other grasses. The grades of the seed usually sold are the grade in the chaff, known as "Prime" and the "Fancy Clean" seed, which is the seed cleaned from the chaff and all impurities. We would strongly advise our customers to sow the Fancy Clean seed in preference to the Prime, or the seed in the chaff, as it will give much better and more satisfactory results. Our Trade-Mark Brand of the Fancy Clean Red Top is of extra fine quality, and carefully cleaned from impurities. We can also furnish the Choice and Prime Fancy Red Top as usually sold. It requires about 8 to 10 pounds to seed an acre of the Fancy Clean seed, or 3 to 5 bushels of the Prime seed in the chaff. When sowing with Timothy, sow 5 pounds of the Fancy Clean seed and 8 pounds of Timothy per acre. It can be sown either in the spring or fall. Price of our Brand Fancy seed, 12c. per 1b.; per 100 lbs. Red Top, in the chaff, about 30c. per bushel of 10 pounds.

\section{JOHNSON GRASS.}

A most valuable permanent hay grass for the South. Tields three or four cuttings per year, yielding one and a half to two tons per acre at a cutting, equal in nutritive qualities to the best Timothy hay.

This is a most valuable crop for the South; it is not properly a grass, but is really a perennial sorghum. It grows rather coarse, but makes a large yield of forage which, when young and tender, is relished by stock, and makes a large yielding crop of either permanent pasture

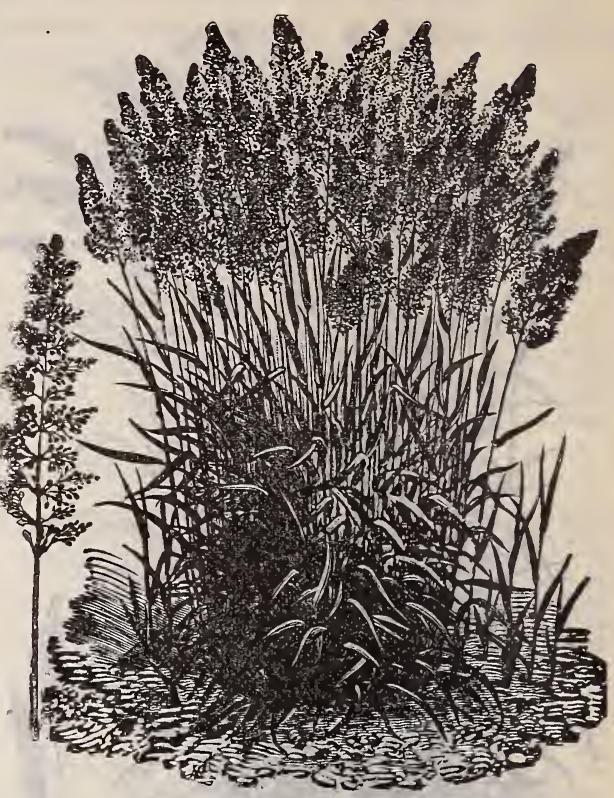

RED TOP, Or HERD'S GRASS,

The most reliable pasturage grass grown, and suc. ceeds on a greater variety of soils than any other grass.

the ground will be required for other crops, as it will be difficult to eradicate it from the soil when it once gets a hold. It should also be cut just as the seed-head is making its appearance, before it flowers. If this is done there is no difficulty in confining it to the fields where it is sown, cut in the way above indicated. If the seed is allowed to form, it not only does not make as good a quality of feed, but the seed being scattered by the droppings of animals, it is likely to appear in cultivated fields and places where it is not wanted. Its nutritive qualities are said to be superior to Timothy hay, and when carefully handled it is one of the most valuable and satisfactory forage crops that the Southern farmer can grow. Letters from customers fully bear out the great value of this crop for the South, the only caution we would give regarding it is to cut it before the seeds ripen, in order to confine it to the fields where it is sown, and don't sow it on lands that you desire to cultivate afterwards in other crops. While it can unquestionably be eradicated from the land by close grazing, or a proper system of cropping, still it is unquestionably be eradicated from the land by close grazing, or a proper system of cropping, still it is
difficult to do so, and it is better to sow where it can remain as a permanent crop. Sow at the rate of one to one and a-half bushels per acre, either in the spring or fall. Thick seeding (one and a-half bushels to the acre), is best, as it produces a finer stalk, which, when well cured, will be eaten up clean by stock, while thin seeding has a tendency to make the stalk coarser and not so good for feed. Besides, a larger yield is made by thick seeding, and costs no more for harvesting. Per bushel (24 1bs.), about $\$ 1.75$. Special price on large lots.

MEADOW FOXTAIL. (Alopecurus Pratensis.)

Fine permanent pasture grass, which does not come to perfection until two or three years old. It is splendid in mixtures for soils of intermediate quality as to moisture or dryness. (See "Special Mixtures," pp. 62, 63.) It resembles Timothy, but is three to four weeks earlier, being one of tne earliest grasses to start in the spring. No grass bears the hot sun better, and frequent mowings do not injure it. Sow 15 pounds per acre. Per 1b. $25 \mathrm{c}$.

RED FESCUE. (Festuca Rubra.)

Valuable hay and pasturage grass, especially for permanent mixtures. It has creeping roots, which in dry and sandy soils are often as strong as wire-grass. Sow about two bushels per acre, if sown by itself: it is best, however, to sow this with other grasses. (See our "Special Mixtures," pp. 62, 63.) Per 1b., 20c.; per bu. (14 lbs.), $\$ 2.00$.

\section{SHEFP FESCUE. (Festuca OVina.)}

Is a densely tufted perennial grass for dry, sandy and rocky soil, where scarcely any other species will grow. It roots deeply, and forms dense short turf, suitable for lawns and pleasure grounds, where the soil is sandy. It affords wholesome food for cattle, especially sheep. Specially recommended for pasturage mixtures. (See "Special Mixtures," pp. 62,63.) Sow about 25 pounds per acre. Per 1b., $20 \mathrm{c}$; ; bushel of 14 lbs., $\$ 2.00$.

HARD FESCUE. (Festuca Duriuscula.)

This does not produce so much as many other grasses, but it thrives well in dry situations where other or high; a great pasture grass; valuable in mixtures. Per bushel (14 lbs.), \$2.00.

WOOD MEADOW GRASS.

An early, nutritious grass. Does well under trees, as it is specially suited for shady places. Recommended for lawn and pasturage mixtures. Per 1b., $40 \mathrm{c}$

ROUGH STAIK MEADOW GRASS. (Poa Trivialis.)

A valuable grass to cultivate in moist, sheltered soils, possessing highly nutritive qualities, coming to perfection at a desirable time, and being exceedingly relished by cattle, horses and sheep. Per lb. $35 \mathrm{c}$. 


\section{HUNGARIAN, or AWNLESS BROME GRASS. (Bromus Inermis.)}

This grass is valuable for light or sandy soils, or dry situations. It roots deeply, and stands protracted droughts well, and will thrive upon soils too poor and dry to grow anything else but broom sedge, hence is valuable for such situations, both for grazing and hay, and especially in mixtures with other grasses. In our tests of this grass it does not prove equal to either Orchard or Tall Meadow Oat Grass. It has, however, been talked up very much in the agricultural press, especially in the West, and is worthy It has, however, been talked up very much in the agricultural press, especially in the West, and is worthy
of extended trial. Sow at the rate of from two to three bushels per acre, either in the spring or fall. Per lb. 20 c.; bushel of 14 lbs., about $\$ 1.75$.

\section{PASPALUM DILATATUM.}

This is one of the most valuable grasses that can be sown in the South, especially in the Gulf States. It is also particularly valuable for the eastern portion of the Atlantic Coast States from Virginia South.

Prof. F. Lamson Scribner, the Agrostologist of the United States Department of Agriculture, says:

"It is considered an excellent pasture grass, and, when well established, endures seasons of excessive drought without injury. It is particularly valuable for furnishing excellent late summer and autumn feed, during which season it makes its principal growth.

Prof. W. L. Hutchinson, Director of the Mississippi Agricultural Experiment Station, says regarding this grass:

"The Paspalum Dilatatum, or Big Water Grass, is the vest variety with us. For wet places and low, marshy lands this is one of the best grasses we have, and, strange to say, where we have some of it on the hills, it apparently stands and grows better than any of the other grasses."

Other reports from farmers who have grown this grass are as follows:

"Paspalum Dilatatum has proved itself worthy of all the praise bestowed upon it. Its great vitality and wonderful fodder-producing powers, as well as rapid propagation, are thoroughly convincing of its great value to the dairy farmer. It would be impossible for me to overestimate its value."

"Paspalum Dilatatum is probably the best fodder or pasturage grass yet introduced, resisting both heat and cold, and yielding enormously. It is much liked by cattle, and is shown by analysis to be of excellent quality."

The best time for seeding is in the months of March, April and May, so as to catch the spring and summer rains. Sow at the rate of 5 to 8 pounds per acre on well-prepared land; it will soon present a thick, well-set pasture. Price, $\$ 1.00$ per lb. Large trial package, 25c., postpaid.

\section{BERMUDA GRASS.}

\section{One of the Most Valuable Southern Pasturage Grasses.}

This is a most valuable perennial pasturage grass all through the South, and also produces good yields of hay on rich soils in the far South. It is very well adapted to light soils, and, in some sections of the South, is the only pasturage grass that will make a good sod on this class of soil. It also does well on clay and loamy soils. It is rather late in starting in the spring, but stands hot, dry weather remarkably well, making a'most valuable summer pasturage grass. It will furnish more summer pasturremarkably well, making a most valuable summer pasturage grass. It wil furnish more summer pasturto eradicate when once established, but this is also a strong recommendation wherever permanent grass is desired. Provided proper methods are used, however, Bermuda Grass land can easily, if desired, be planted in other crops, the only requirement being that the Bermuda Grass sod be deeply ploughed and thoroughly inverted, so as to give the crops that are planted on same a good start, when the shade from these will prevent the Bermuda Grass from growing. Fine crops of cow peas, corn, and wheat have been raised on Bermuda Grass sods, that, previous to the land being taken up in it, would hardly produce a crop at all, showing that Bermuda Grass is not only a most valuable permanent pasturage grass, but is also a valuable permanent improver of the soil. The seed should be sown in March or April, at the rate af three to five pounds per acre. Prepare the ground well, making a good, firm, seed-bed, as the seed is small, and cover very lightly with roller or brush harrow (roller is best) to a depth of not more than half an inch. Price of seed, $60 \mathrm{c}$. per 1b.; in 10-1b. lots and over, 50c. per lb. Special price on large lots.

\section{BEGGAR WEED. (Desmodium Molle.)}

Highly recommended as a forage plant for thin sandy lands and pine barrens; vigorous growth, two to five feet high, yielding largely for hay and pasturage; nutritive value compares favorably with Red Clover, cow peas, etc.

On the sandy pine lands for the South Atlantic and Gulf States it is probably the most valuable forage plant that can be grown. Its growth is dense; two to four feet high; some times seven feet; the forage crop abundant and nutritious."

Sow at any time after frosts are over until the middle of June, in drills three feet apart, three or four pounds per acre, or broadcast ten to twelve pounds per acre. Cover one to two inches. When two feet high, may be cut for hay or green feed, and will produce successive crops, branching largely from the an inch. Price of seed, $40 \mathrm{c}$. per lb.; in 10-1b. lots and over, $35 \mathrm{c}$. per $1 \mathrm{~b}$. Special price on large lots.

\section{UPLAND RICE.}

An excellent variety of rice, which yields a most satisfactory crop on any good, stiff, upland soil, being particularly well adapted for clay soils. It will make a larger yield of grain than corn on the same land, and with less work. Plant fifteen to twenty-five grains in a hill, just far enough apart to admit of hoeing, and rows far enough apart to plow. Should be planted in this section from the first of April to the middle of June. It is best planted in April, however. In addition to its value to grow as a crop for sale, it makes most excellent feed for horses, hogs, and poultry. The straw is equal to timothy hay, and one of the largest growers in the South says, "I can throw away either the rice or the straw and come out better than with my cotton crop, even at present prices." Price, 10c. per pkt.; 20c. qt.; 70c. peck; $\$ 2.25$ bushel.

\section{CAROTINA RICE.}

The variety most largely used for seeding in the Carolinas. Pkt. 10c.; qt. 20c.; peck, 60c.; bu. $\$ 2.00$

\section{JAPAN RICE.}

Our stock of this is grown from imported seed. This variety is being very largely planted in Louisiana to the preference of other kinds. Pkt. $10 \mathrm{c}$.; qt. $20 \mathrm{c}$.; peck, $75 \mathrm{c}$; ; bu. $\$ 2.50$.

WEST CAIRNS, ALBEMARLE CO., VA., Dec. 17, 1902.-I procured from you last spring seed corn of the variety known as Holt's Strawberry. It has yielded tremendously. I have planted it on a creek bot-

tom, and $I$ think it is the best crop of corn harvested in this neighborhood, where we always make a good
crop. crop.

AMELIA CO., VA., May 5, 1902.-I have used Tobacco Dust as an insecticide and fertilizer on grass and vegetables. It is the best fertilizer for top-dressing I ever used. In fact, I think it is the best I ever. W. W W 


\title{
WOOD'S CELEBRATED
}

\section{GRASS AND CLOVER. SEED MIXTURES.}

\author{
MIXTURES FOR HAY.
}

MIXTURES FOR PASTURES.

\section{Special Mixtures for Different Soils and Purposes.}

WOOD'S GRASS AND CLOVER SEED MIXTURES give the very best and most satisfactory results to our customers, and our trade in them is increasing rapidly every year.

The special mixtures which we offer are the results of many years of experience and careful experiment, and we are constantly benefiting by our experience in improving the combinations of the different mixtures offered, as the grasses prove more successful on various soils.

The advantage of sowing grasses and clover seeds in mixtures has long been recognized, and the practice is increasing to a very remarkable extent all through the South. We were the pioneer seeds-

MITURES
are always put up from our
TRADE=MARK BRAND,
which are the highest qual-
ity seeds obtainable, both as
to germination and purity.
men in putting up special mixtures for different soils, and the results to our customers have been eminently satisfactory. We are always glad to give our customers the benefit of our knowledge and experience in these matters, and will take pleasure in advising them as to suitable grasses for their soils and purposes, if they will correspond with us in regard to the same.

We have in the following mixtures combined grasses suitable for the various soils and use for which they are recommended. Those for permanent pastures are composed of grasses which succeed each other in growth, and give a succession from the first of spring until late in winter, while for those desired more for cutting for hay, we have combined grasses which ripen together. The different mixtures are prepared both as to quantity and varieties as best adapted to the soils and situations for which they are recommended.

In all of our grass mixtures we use the very best seeds only, the quality and purity of the seeds being our first consideration. The quantity handled enables us to give our customers the benefit of a very low price, even lower than if they purchased the seed separately.

We glve below the kind of grasses contained in the different mixtures; all are mixed in suitable proportions as best adapted for the soils recommended.

MIXTURES Nos. 1 to 5, For Permanent Pasture, but can be Mown.

Twenty-five pounds or over of any of these mixtures supplied at 100-pound rates.

MIXTURE No. 1.-For Light, Dry, Gravelly, or Sandy Soils.

Composed of the followirg grasses:

Tall Meadow Oat Grass,

Crested Dog's Tail,

Hard Fescue,

Sheep Fescue,

Meadow rescue,

Orchard Grass,

Fancy Bed Top,

Perennial IJe Grass,
Fungarian Brome Grass,

White Clover,

Red clover.

Poa Compressa.

Sow $35 \mathrm{lbs}$. to the acre. Price, 15c. per 1b.; 100-1b. lots and over, 14c. per lb.

MIXTURE No. 2.-For Good Loam Soil.

Composed of the following grasses:

Meadow roxtail,

Meadilidow Oat Grass,

Poa Compressa,

Perennial Rye Grass,

Fancy Rea Top,

Italian Iye Grass,

Ied Fescue,

Red Clover,

White clover.

Sow $35 \mathrm{lbs}$. to the acre. Price, 15c. per 1b.; 100- lots and over, 14c. per $1 \mathrm{~b}$.

MIXTURE No. 3.-For Heavy Loam or Clay Soils.

Composed of the following grasses:

\section{Meadow Foxtail,}

Orchard Grass,

Pancy Red Top,

Italian Rye Grass,

Meadow rescue,

Tall Meadow Oat Grass,

Alsike Clover,

Red Clover,
White Clover,

Irentucky Blue Grass,

Perennial Rye Grass,

Creeping Bent.

Sow $35 \mathrm{lbs}$. to the acre. Price, 15c. per 1b.; 100-1b. lots and over, $131 / 2 \mathrm{c}$. per $1 \mathrm{~b}$.

MIXTURE No. 4.-For Moist Bottom Land.

Composed of the following grasses:

Creeping Bent Grass,

Kentucky Blue Grass,

Meadow soxtail,

Timothy,

Orchard Grass,

Alsike Clover,

Wood Meadow Grass,

Meadow Pescue,

rancy Ied Top,

Sow 35 lbs. to the acre. Price, 15c. per lb.; 100-lb. lots and over, $131 / 2$ c. per Ib.

MIXTURE No. 5.-For Wet Bottom Land.

Composed of the following grasses:

Rough Stalked Meadow Grass, Meadow Fescue,

Fancy Red Top,

Italian Rye Grass,
Meadow Foxtail,

Timothy

Alsike Clover

Creeping Bent Grass,

Sow $30 \mathrm{lbs}$. to the acre. Price, 15c. per 1b.; 100-1b. lots and over $131 / 2 \mathrm{c}$. per lb.

Wood Meadow Grass,

Mammoth Clover,

Sheep Fescue. 


\section{MIXTURES Nos. 6 to 9, For Mowing for Hay, but can be Grazed.}

Twenty-five pounds or over of any of these mixtures supplied at 100-pound rates.

MIXTURE No. 6.-For Light, Dry, Gravelly or Sandy Soils.

Composed of the following grasses:

\section{Orchard Grass,}

Tall Meadow Oat Grass

Red Fescue,

Sow 35 lbs. to the acre. Price, 15c. per 1b.; 100-1b. lots and over, 14c. per $1 \mathrm{~b}$.

MIXTURE No. 7,-For Good Loam Soil.

Composed of the following grasses:

\section{Meadow Foxtail,}

Tall Meadow Oat Grass,

Meadow rescue,
Red Fescue,

Red Clover.

Sow $35 \mathrm{lbs}$. to the acre. Price, 15c. per 1b.; 100-1b. lots and over, 14c. per 1b.

MIXTURE No. 8.-For Heavy Loam or Clay.

Composed of the following grasses:

\section{Meadow Fescue,}

Orchard Grass,

Kentucky Blue Grass,

Meadow Foxtail,

Tall Meadow Oat Grass,

\section{Fancy Red Top;}

Red Clover,

Timothy. Sow 35 lbs. to the acre. Price, 15c. per lb.; 100-1b. lots and over, 131/2 c. per 1b.

\section{MIXTURE No. 9.-For Moist Bottom Land.}

Composed of the following grasses:
Fancy Red Top,

Timothy,

Meadow Fescue,
Sapling Clover,

Kentucky Blue Grass,

Alsike Clover,

Rough Stalked Meadow.

Sow $20 \mathrm{lbs}$. to the acre. Price, 15c. per 1b.; 100-1b. lots and over, 13c. per $1 \mathrm{~b}$.

MIXTURE No. 10.-For Good Loam Soil, Shaded with Trees.

FOR PASTURE OR HAY. Composed of the following grasses:

\section{Wood Meadow Grass,}

Orchard Grass,

Hard Fescue,

Meadow Foxtail,

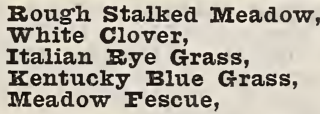

Rough Stalked Meadow,

White Clover.

Italian Rye Grass,

Kentucky Blue Grass,

IMeadow Fescue,

\section{Fancy Red Top, \\ Red Clover, \\ Perennial Iye Grass, \\ Crested Dog's Tail.}

Sow $35 \mathrm{lbs}$. to the acre. Price, 15c. per 1b.; 100-1b. lots and over, 14c. per 1b.

Twenty-five pounds or over of any of these mixtures supplied at the 100-pound rate.

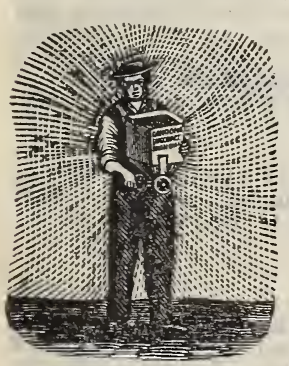

\section{PREMIER BROADCAST SEED SOWER.}

The Premier Broadcast Seed Sower is giving universal satisfaction wherever used and is claimed to be the strongest, neatest, and most effective hand seed sower made. The Premier will sow any seed that is sown broadcast, such as oats, wheat, rye, rice, flax, millet, clover, timothy, grass seed, etc. Under ordinary conditions it will sow at a round about as follows: Wheat or rye, 50 feet; clover, flax, or millet, 40 feet; grass seed, 24 to 36 feet.

This is a low-priced seeder, but does very effective work, and while the Cahoon Broadcast Seed Sower will probably prove a better implement in the long run, where much seeding is to be done, the Premier will give entirely satisfactory results. Price of Premier Seed Sower, $\$ 1.25$ each.

\section{CAHOON BROADCAST SEED SOWER.}

For Sowing Seed Grain, Clover Seed, Itc.

The best Seeder manufactured, and sows all kinds of grain, clover seeds, etc., rapidly and evenly. A person entirely unused to seeding can, by following the simple directions sent with machine, sow from four to six acres an hour at a common walking gait. It sows more uniformly, and saves four-fifths in labor by its use. Every farmer should have one of these sowers. Circulars giving full information and directions for use, mailed on application. Price, $\$ 3.00$.

\section{LAND} PLASTER makes a splendid top dressing for Grass and Clover crops in the SPRING.
A supply of Land Plaster should always be kept on hand by every farmer. The well known benefit derived from the application of this as a top-dressing for Grass and Clover in the spring should make it universally used for this purpose. It is most useful as an insecticide, and to use when planting Potatoes, and also to use in stables, cattle-stalls, chicken houses, on manure piles, etc. It will add very largely to the manure value of the farm if it is freely used, as it prevents the escape of ammonia, at the same time stopping foul odors and adding to the cleanly appearance of stables, etc., where used. As a top dressing for Grass and Clover crops, it should be applied at the where used. As a top dressing for Grass and Clover crops, it should se spring. Price of Iand Plaster, $75 \mathrm{c}$. per bag of $200 \mathrm{lbs}$ : $\$ 7.00$ per ton. Special prices in large lots. 


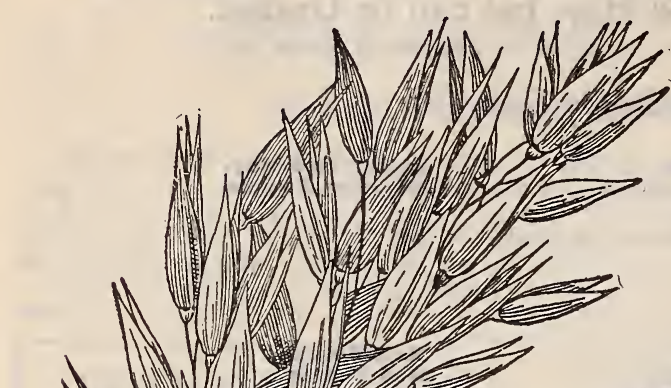

\section{SEED OATS.}

BURT, OY NINETY-DAY OATS.

We have grown this oat for two seasons past on our Hollybrook Farm, and it has proved unquestionably to be the earliest spring oat grown, and at the same time produces most satisfactory crops. On account of its earliness to mature, it escapes the hot, dry weather which we frequently experience in June, and is, on this account, one of the surest cropping varieties for the South. It has proved very popular wherever it has been grown, and is really a most valuable spring oat. Color and appearance of grain vomewhat resembles the rust-proof oat, but is a little lighter in color. Price, $\$ 1.00$ per bushel; in 5-bushel lots and over, $90 \mathrm{c}$. per bushel.

\section{IOWA SIIVIR MINE OATS.}

This oat originated in the West. where it has become very popular, as it has proved itself to be one of the largest yielding and most satisfactory white spring oats. It will give very much better crop results and larger yields than the ordinary White Spring Oats. Price, 75c. per bushel; in 10-bushel lots and over, $65 \mathrm{c}$. per bushel.

\section{GARTON'S TARTAR KING OATS.}

We have sold this oat to our customers for the past two seasons. with the most satisfactory and profitable results and it has proved of much more vigorous growth, and larger yielding, than any other oat in this section, and our customers who have grown it are enthusiastic in its praise. It is remarkable for its leafy, vigorous growth, large heads and well developed grain. Its growth and appearance always cause the most favorable comment. In England, where it originated, it has proved to be the first in yield, first in earliness, first in strength of straw, and first in quality and size of grain. It is very heavy white oat, weighing 40 to $45 \mathrm{lbs}$. to the measured bushel, and is the most valuable acquisition in oats that has been made in recent years. Price, large-sized trial package, 10c.; peck of 8 lbs. $50 \mathrm{c}$; bushel of $32 \mathrm{lbs}$. $\$ 1.40$; 5 -bu. lots and over, $\$ 1.25$ per bushel.

\section{VIRGINIA GREY WINTER, OI TURF OATS.}

For Spring Seeding.-These succeed splendidly, and make surer crop and larger yield than Spring Oats, provided they are put in early, before the middle of March. Sow at the rate of one and a-half to two bushels per acre. Price fluctuates. Present price Trade-Mark Brand, $80 \mathrm{c}$. per bushel. In 10-bushel lots and over, $75 \mathrm{c}$. per bushel. Choice quality, 70c. per bushel.

\section{RED RUST-PROOF OATS.}

These are largely used, both for spring and fall seeding, and give very satisfactory yields of fine, heavy grain. The Rust-Proof Oats are not inclined to rust anything like as much as other varieties, and are especially valuable and desirable for sowing on low grounds. They also succed remarkably dell on upland soils, and are increasing in popularity all through the South. Price, Trade-Mark Brand, best and cleanest quality, $70 \mathrm{c}$. per bushel; in 10-bushel lots and over, $65 \mathrm{c}$. per bushel. Special prices on large lots.

\section{BIACK SPRING OATS.}

These are usually considered to be the heaviest yielding of Spring Oats. Price of our Trade-Mark Brand, $60 \mathrm{c}$. per bushel, bags included; prime quality Black Spring Oats, 55c. per bushel. Special prices on large lots.

\section{WHITE SPRING OATS.}

Sow at the rate of two bushels per acre in February, March or April the earlier the better. Price of our Trade-Mark Brand (heaviest and cleanest quality), about 60c. per bushel, bags included; prime quality of White Spring Oats, about 55c. per bushel, bags included. Special prices on large lots.

\section{RYE.}

This crop is very largely used all over the South for winter pasturage, early

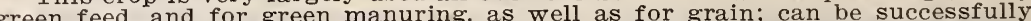
green as early as July and as late as December. Is also sown in the spring for sown as early as July and as late as December. Is also sown in the spring for
grazing. Sow one and a-half to two bushels per acre. Present price is $85 \mathrm{c}$. per bushel, bags included. Specia! prices on large lots.

\section{SEED WHEAT.}

We sell thousands of bushels of the best and most improved varieties of seed Wheat every year, and our wheats have attained a very high reputation on account of their cleanness and superior quality. We issue in August a descriptive llist of seed Wheats and other seeds for fall sowing, which we shall take pleasure in mailing to any one upon request.

WASHINGTON CO., VA., April 14, 1902.-I have been a customer of yours for two or three years. I hope to be able to order a quantity of grass seed this fall, as all I have gotten from you have proved very satisfactory.

NEW HANOVER CO., N. C., May 7, 1902.-All of your seeds have given entire satisfaction. 


\section{SOJA BEANS.}

Unquestionably the Richest and Most Nutritious Forage and Feed Crop Orown, Making the "Balanced Feed" for Hogs, Dairy Cows, and Fattening Stock. Also, Makes a Splendid Soil Improver, and is Unequalled as a Drought-Resisting Crop.

We give below extracts of letters from our customers. calling attention to some of the principal points of value in our Yellow Soja Beans. This crop withstands drought better than any other forage crop, and seems capable of making its growth in spite of more adrerse conditions than any other crop which we have ever grown. In point of nutritive value it is unequaled, and makes in connection with corn, as a number of our customers state, a "balanced ration" grown upon the farm, saving the farmer from paying out cash for oil meals, bran, etc.

Our Yellow Soja Beans should unquestionably be one of the staple crops with every farmer.

"Far Superior to Cotton Seed Meal to Make Milk and Butter."

"SPARTANBLRG CO., S. C., Nor. $25,-901$. - I bought of you a peck of Soja Beans; planted on one acre of common cotton land, rows two and a-halt feet apart. I made eleven large one-horse loads. I threshed out two loads, got five bushels, or twenty-seren and a-half bushels, on the acre of beans, besides eleven loads of hay, far superior to cow pea hay. II horses quit eatin corn to eat them in the chaff. I feed to my cows. and they are far superior to cotton seed meal to make milk and butter. MI chickens eat them like eating corn; hogs also go for them. I consider them the finest thing a farmer can plant, and all farmers should by all means plant them-from one to twenty acres. I expect to rent ten acres to plant them on next year. I used 200 pounds guano; hoed one time; plowed twice.

'CHARLES MOORE."

"Far Superior to the Cow Pea as a Crop Bearer, as they will produce Double the quantity of Peas, and Fqually as Much, if not More Iitter."

"NANSEMOND CO., VA., Jan. 18, 1901.-The Soja Beans bought of you turned out very well. I consider them far supericr to the Cow Pea as a crop bearer, as they will produce double the quantity of peas, and equally as much, if not more, litter. . . For fattening hogs they are very good, lasting for such a long time. They will keep in the

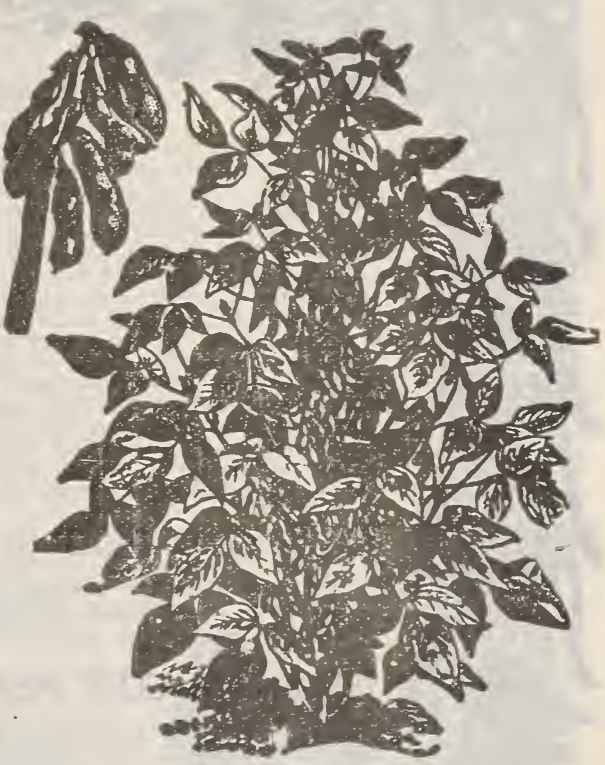

SOJA BEANS field until after Christuas without spoiling; hence they fill the place of acorns or meat for stock or hogs. soil improver they are the equal, if not the superior, of the Cow Pea, as they produce more forage, and when they are done shedding, the lands is covered with leaves, pods, and stems.

"The richest green food I have ever grown for cattle."

"FORSYTH CO., N. C., Nov. 20,1900 .- In feeding value, Soja Beans are far superior to Cow Peas. As a green feed for dairy cattle, I consider them the richest green food I have ever grown for cattle. I believe, planted in connection with, or separate from, ensilage corn, and put into silo at the same time, in proportion of one ton of Soja Beans to two tons of corn, that they would in a great measure make a 'balanced ration' grown on the farm, which, as you know, is the crying need of the hour in dairy circles

"All kinds of stock will eat Beans in preference to Corn Fodder."

ELLIOTT WARREN."

"YORK CO., VA., Feb. 7, 1901.-All kinds of stock will eat Soja Beans in preference to corn foddex. Once tried, always tried, as they are the surest crop a man can plant. Never too dry nor too hot for this grand old forage plant. Just give them a chance and they will surprise you with a big crop.

"D. W. MORRIS."

When sown broadcast for forage and soil-improving crops, the Soja Beans should be sown at the rate of one bushel per acre. Sowing them thickly will prevent the stalk from growing too coarse, and enable them to be cut and turned under to better advantage. Sowing for ensilage, it is better to sow in drills with corn, at the rate of about one peck to the acre. Or they can be sown by themselves in drills three feet apart, at the rate of one to one and a-half pecks per acre, and cultivated. They will make their largest

yield of beans put in this way. cidedly inferior to the stock we supply. The letters given above refer to our own strain of Yellow Soja, which we have been supplying to our customers for several years past.

Large pkt. 10c.; peck, 50c.; bu. \$1.50. Price fluctuates. Specla] price on large lots.

\section{WHITE NAVY BEANS.}

Planted in June or July, these usually make a very profitable crop to grow as shelled white beans for market. Plant in rows three feet apart, dropping two or three beans together a foot apart in the rows. Cultivate early, as they grow rapidly, but do not work them while the dew is on the foliage; and care should be used not to cultivate deeply after they are three or four inches high. Do not cultivate after they begin to blossom Carefully grown these will prove a profitable and successful crnp. It requires about a peck to plant an acre. Qt. 15c.; peck, 90c.; about $\$ 3.00$ per bushel. Special price on large lots.

CALDTELL CO., N. C., Feb. 20, 1902.-Please let me thank you for your gentlemanly treatment of me in all our dealings, and the good quality of your seeds, specially your melon and g.ass seeds. I always ráve had success with them. I have sold $\$ 60.00$ worth of melous from $\$ 100$ worth of seed purchased from you, in less than six months from purchasing trie seed.

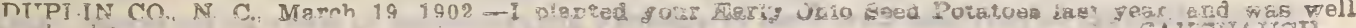

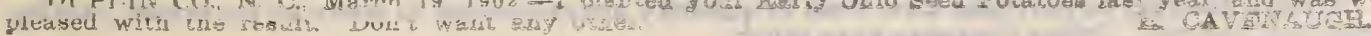




\section{COW OR FIELD PEAS.}

The Great Soil Improvers. Makes Poor Land Rich." Makes Good Land Ilore Productive. Also Makes a Splendid and Nutritious Gireen Forage or Hay Crop, Enriching the Soil even when the Crop is Cut Off.

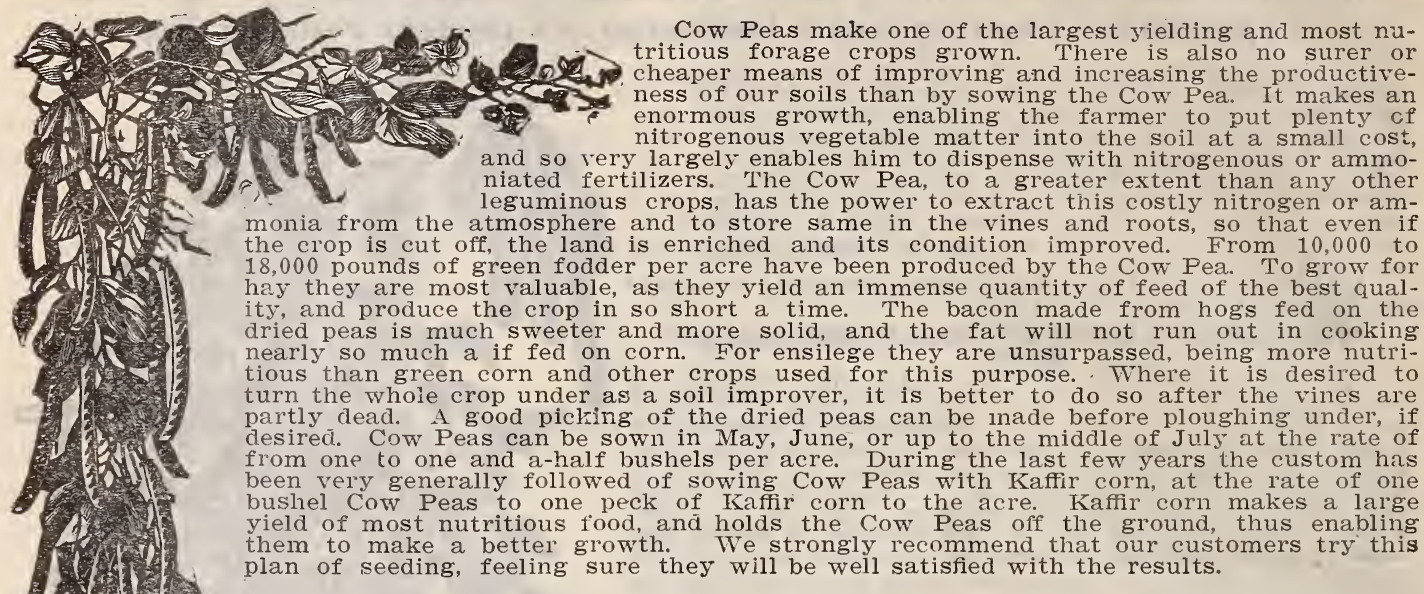

\section{IRON COW PEA.}

A new variety, remarkabie for its disease-resistant qualities, and also for its value for forage on account of holding its foliage longer than other kinds. For full description, see "Seeds of Special Merit," page 7. Pkt. 10c.; qt. 20c.; peck, $\$ 1.00$; bu. $\$ 3.00$.

\section{INEW ERA COW PEA.}

This new extra early Cow Pea is unquestionably one of the most valuable varieties in cultivation, and is particularly well adapted for planting in the North and West, where the seasons are shorter than they are in the South. It is quicker in growth than any other Cow Pea in cultivation; makes a very large growth of vine and very prolific yield of peas. The vines stand upright, enabling the peas to be easily gathered. The peas are fully one-third smaller in size than the ordinary Cow Pea, so that it does not require nearly as many to seed an acre as of the ordinary varieties. From one-half to three-fourths of a bushel per acre will give ample seeding. Price, per pkt. 10c.; qt. 20c.; peck, 90c.; bu. $\$ 3.00$.

\section{RED RIPPER.}

Red seeded; a most desirable and productive variety, somewhat resembling the Black in growth of vine, but ten days earlier and more prolific. Wherever it has been grown it is rapidly coming into favor. Price, 10c. per pkt.; 15c. per qt.; 50c. per peck; about $\$ 1.60$ per bushel.

\section{BLACK COW PEA.}

This is the variety most largely grown in this immediate section. It is very prolific, quicker to mature than the Wonderful or Unknown, and is better adapted for later planting, or for growing in districts further north than Virginia. It is a splenusd land-improver, and most valuable as a forage crop, making an enormous yield of rich, nutritious feed. It yields more largely of the shelled peas to the acre than the Wonderful. Price fluctuates. Price. January 1st, $\$ 1.50$ per bushel. Special price on large lots. In small quantities, per pkt. $10 \mathrm{c}$., postpaid; qt. 1 ćc; peck, $50 \mathrm{c}$.

\section{TAYLOR.}

This is a large speckled pea, making a largel growth of vine than the Black Cow Pea, and maturing about the same time. It makes a very much larger yield of shelled peas to the acre than the Black Pea, and on account of its superiority, both in this respect and the growth of its forage, is bound to become very popular wherever grown, and when its merits become fully known, we believe that it will supplant, to a very large extent, the popular Black Pea. Pkt. 10c., postpaid; qt. 15c.; peck, 60c.; bu. about $\$ 1.60$.

\section{WONDERFUL, OR UNKNOWN.}

This popular variety makes an enormous and remarkable growth of vines, but requires the full grow. ing season to make its crop. In yield and growth of vines it surpasses any of the varieties of Cow Peas, and it yields very largely of the shelled peas. It will also hold its leaves and foliage better than other kinds, which gives it a decided advantage where it is sown for hay or forage. This variety should be planted in May in order to come to full maturity. Price fluctuates. Price, January 1st, $\$ 1.50$ per bushel. Special price on large lots. In small quantities, pkt. 10c., postpaid; qt. 15c.; peck, 50c.

\section{WHIPPOORWILL.}

A favorite early bunch-growing variety, has brown-speckled seed, which are more easily gathered than from the vine-growing sorts. This variety is a prime favorite in the North and West on account of its early maturity and habit of growth. Price fluctuates. Price, January 1st, $\$ 1.60$ per bushel. Special price on large lots. In small quantities, pkt. 10c., postpaid; qt. $15 \mathrm{c}$; peck, 50c.

Parmers desiring to purchase Cow Peas in quantity are requested to write us for prices, stating funtentieg doeirod. Prices fluctuate very much. 


\section{LARGE BLACK-EYE PEAS.}

The Large Black-Eye Peas are more prolific, better flavored, and bring a higher price than the ordinary Black-Eye, and farmers will find it more profitable to plant these than the ordinary Black-Eye; they make a more profitable crop to grow for picking the dry peas for sale in our markets during the winter, at the same time make an excellent soil improver, being similar in growth of vine and action of roots upon the soil to the Black and the Wonderful Cow Peas. While, of course, allowing the peas to fully mature, and harvesting the dried peas detracts somewhat from their value as an improver, still where parties desire to make a money crop and at the same time to improve the soil, these are especially desirable. Pkt. 10c., postpaid; qt. 20c.; peck, 75c.; bu. $\$ 2.25$. Price fluctuates. Special price on large lots.

\section{CLAY COW PEAS.}

A favorite variety in some sections of the South. Makes a growth of vine and pods similar to the Black Pea, but is a little later in maturing. Is prolific, both in yield of peas and growth of vine. Price fluctuates. Price, January 1 st, $\$ 1.40$ per bushel. Special price on large lots. In small quantities, pkt. $10 \mathrm{c}$., postpaid; qt. $15 \mathrm{c}$; peck, $50 \mathrm{c}$.

\section{EARLY BLACK-EYE.}

This extra early variety pea matures its crop two or three weeks ahead of the ordinary or Large or Black-Eye Pea, and on this account is of great value for growing for green peas for market, as it enables the gardener to obtain very much hioher prices fo: them. The peas are of medium size, very productive, the best flavored of any of the Cow Peas, and on account of their extreme earliness, are of great value to our market gardeners. Pkt. 10c., postpaid; qt. 20c.; peck, 75c.; bu. $\$ 2.75$.

\section{SOUTHDOWN.}

A very prolific Southern variety, not only valuable for the growth of vine, but also makes a pea of good qualities. It is largely used in place of the Black-Eye Pea. It makes a good growth of vine. early to mature, producing its crop in about the same time as the Whippoorwill. Price, 10c. per pkt.; 15c. per qt.; 50c. per peck; $\$ 1.40$ per bu.

\section{THE GALLAVANT, OR LADY PEAS.}

This is an old-fashioned pea, which is very popular in sections where it is known. The peas are small in size, very fine flavor; superior in table qualities to the Black-Eye pea. It is very prolific, and a desirable variety to grow. It is known in some sections as "The Lady Pea." Price, per pkt. 10c.; peck, 75c.; bu. $\$ 2.50$.

\section{MIXED COW PEAS.}

The principal varieties in the Mixed Cow Peas we offer are the Clay, Southdown, Wonderful, Whippoorwill and other Southern varieties. A great many Southern farmers prefer to sow Cow Peas in mixture, as they grow thicker, producing a better crop of vines and forage than sowing single varieties alone. Price, 50c. peck; about $\$ 1.25$ bushel. Price fluctuates.

\section{VELVET BEANS.}

\section{The Famous New Forage and Soil Improving Plant.}

The popularity of this bean is increasing enormously, and it is now being very generally grown all throughout the South. It makes an enormous growth of vines, greater than any other known forage plant in the same length of time, far surpassing the Cow Pea in yield. The great possibilities of this bean as a land improver and for producing a good crop of forage seem almost unlimited. It has been thoroughly tested in all seem almost States, and experienced agriculturists pronounce it of the greatest States, and experienced agriculturists pronounce it of the greatest
value. The vines and roots are very rich in nitrogen, making it a most valuable soil-improving crop. The vines grow so rank that it is with great difficulty that they can be turned under in the green state, and it is much better, if it is possible, to leave them above the ground until after frost kills them, and to plough them under in the winter or early spring at which time they will make a heavy matted coating of vegetable matter, which, turned under, will benefit the soil almost equal to a heavy application of stable manure. The vines and beans also make a most nutritious feed, and we strongly recommend our customers all throughout the South to plant these beans on a large scale, feeling sure that they will be more than satisfied with the results from same. These beans should be planted in May or June, at the rate of one and a-half pecks to the acre, in drills five feet apart. They soon make qt. $15 \mathrm{c}$; peck, $60 \mathrm{c}$; bu. about $\$ 2.00$. Bushel price fluctuates. Special price on large lots.

\section{BIRD SEED-Wood's Songster's Food Brand.}

Bird fanciers know that to keep canaries and other small song birds in good health and song it is most important that they should be fed with the greatest variety of pure seed adapted to their requirements. To meet such needs, we have specially prepared a perfect seed mixture, composed of severa varieties of the best and cleanest seeds known as a food and tonic, which we offer under our trade-mark as "Songster's Food, or Wood's Perfect Bird Seed Mixture." This is put up in one-pound illustrated cartoons or boxes. $10 \mathrm{c}$. per box; three boxes for $25 \mathrm{c}$

Canary Seed. L,b. 10c.; 3 lbs. for $25 \mathrm{c}$

Hemp seed. For parrots, pigeons, etc. Lb. 10c.;

Bird Rape. Per 1b. $10 \mathrm{c}$. 3 lbs. for $25 \mathrm{c}$ 


\section{SEED CORN--White Field Varieties.}

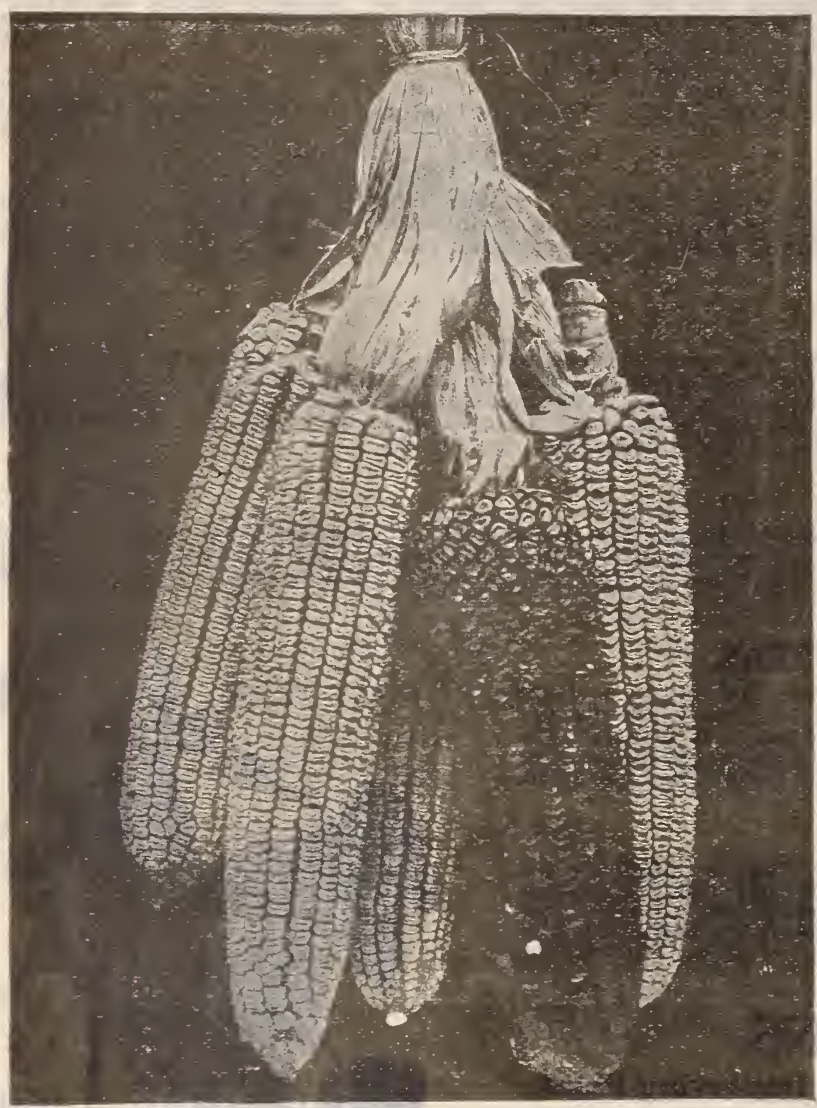

Holt's Strawberry Corn.

Our Virginia grown seed corn gives the very best and most satisfactory results all through the South, succeeding and giving much better and more satisfactory yields than corn grown in the North and Tiest. We are constantly receiving large numbers of voluntary testimonials from our customers, testifying to the fine results from planting our seed corns, and our sales have increased to a very large extent all throughout the South. We do not believe that in the history of the seetrade there was ever offered a better selection of the varieties of corn adapted to the South than we offer in the following list. All of them have been thoroughly tested, and can be recommended and planted with confidence.

\section{FUREKA CORN.}

For full description of this splendid "Sew and large yielding variety, see 10c; at. $20 \mathrm{c}$; peck, 60c.; page $0 \%$ Pkt. MOSBY'S PROIIFIC CORN.

An improved prolific corn, which has given splendid results wherever grown. It is a pure white corn; very small white cob and deep. full grain; neither very hard nor very soft. Produces an average of two or three good-sized ears to the stalk. In tests made in our trial grounds last season. we were particularly pleased with this variety. Tre believe it will prove to be one of the most valuable and prolific varieties in cultivation. Pkt. 10c.; qt. $20 \mathrm{c}$; ; peck, $50 \mathrm{c}$; bu. $\$ 1.60$.

\section{HOIT'S ITRAWBERRY CORN.}

This corn produces a very large ear, and often two ears to the stalk. the ears running from ten to twelve inches in length and from fourteen to sixteen rows to the ear. The grain is very large and deep, with comparatively snall red cob. It makes a large growth of fodder, and good-sized stalk. It is rather late in maturing. preserving its fodder in good shape after earlier corn is dried up, and withstands drought better than any other corn with which We have had experience, this character-

those who have grown it. It is a white corn, obut some ears of strawberry or striped grain appears in it, hence its name Even the striped or red grains, however, make white meal, as the stripe is only on the skin of the grain. We unhesitatingly recommend this corn to our customers as one of the most satisfactory and largest yielding field corns in cultivation. It is one of the best corns for feeding to stock. as the kernel contains much more nutritious matter, and in this respect it is much superior to corns of a flinty. nature. Pkt. 10c., postpaid; qt. 20c.; peck, 50c.; bu. \$1.50; 5-bu. lots and over, $\$ 1.40$ per bus'lel.

\section{COCRE'S PROTIFIC CORN.}

This is a valuable variety of white corn, first produced by the late General Cocke on his plantation on the James River. Since that time it has been very greatly improved by careful selection and cultivation. On land of good fertility, and especially on river low grounds, it may be relied upon to produce from two to four ears to the stalk, and we have seen growing as high as eleven gond ears to the stalk. Tliis prolificacy makes it a heavy yielding corn. One farmer in Fluvanna county, Ta.. produced 160 bushels if corn of this variety on one acre of land, and 1.575 bushels on 15 acres, or an average over the 15 acres of 105 bushels per acre. Had the season been a more propitious one, he believes the yielu would have been still greater. The ears are of good average size, the grain being of a wlite, flinty nature, making an excellent meal or hominy corn. Pkt. 10c., postpaid; qt. 15c.; peck, 50c.; bu. $\$ 1.40 ; 5$-bu. lots and over, $\$ 1.25$ per bushel.

\section{HICKORY RING.}

One of the best and most productive white corns in cultivation, especially for high land. and is in great favor with those who have planted it. It produces on good soil three or four average-sized ears
to the stalk. The grain is large and beautifully white, making the finest guality meal. The cob is often so small that a large-sized grain will cover the end of it. Pkt. 10c., postpaid; qt. 15c.; peck, $50 \mathrm{c}$.; bu. \$1.40.

\section{WHITE MAJמSTIC CORN.}

This splendid white corn gave the most satisfactory results the past season, and we received a number of letters from customers who planted it who are enthusiastic in its praise. It is one of the best yielding white corns grown; nearly always makes two ears to the stalk. The grain is deep, large sized, and always fills out well to the end of the ear. It makes a large-growing stalk, with plenty of fodder, and is a most valuable ensilage variety. For main crop corn on upland or light soils it is one of the best and most nroductive valictios that can he nlanted. Produces a stalk eight to ten feet high. Price, pkt. 10c.; 4t. 15c.; jeck, 60c.; Nu. \$1.50. 
IMPROVED SOUTHERN WHITE SNOWFIAKE.

This is a most valuable white field variety, one that makes a large yield, and, when ground, makes meal of the finest quality. It also makes a splendid roasting-ear corn, being deep-grained, producing largesized ears, of a shape that is most salable for green corn in our markets. It is an early and quickgrowing variety, maturing its crop in about 100 days. It grows about eight feet in height; ear set: four to five feet from the ground. Nearly always produces two ears to the stalk. Does not blow down easily, and is valuable for replanting. Will make good corn on poor land where other sorts with large stalks would fail. Our market-garden customers will find this a particularly valuable sort for making green corn to sell for roasting-ears. Pkt. 10c., postpaid; quart, 20c.; peck, 60c.; bu. $\$ 1.75$.

GENTRY FARIY MARKET.

A very early, good-sized variety, making a flinty white corn. It is very hardy, and can be planted early in the spring as well as late in the summer, after it is too late to plant other varieties, as it matures very quickly. It not only makes a splendid field corn, but is a fine early market rariety to sell for green corn, and superior in yield to any other variety of early corn we know of, especially for light land. It has a small stalk, grows seven to ten feet high, and has two or three large ears set low on the stalk. Pkt. 10̈., postpaid; qt. 20c.; peck, 60c.; bu. $\$ 2.00$.

\section{BLOUNT'S PROIIFIC.}

This remarkably prolific corn was introduced by Professor Blount, who, starting with two ears to the stalk, has succeeded in improving it so as to produce from three to six ears. It is a large yielding white variety of flinty nature, making excellent meal. Reports of this corn from Texas and Alabama experiment station, rank this as one of the largest yielding of field varieties for the Soutl. Pkt. 10c., postpaid; qt. $15 \mathrm{c}$.; peck, $50 \mathrm{c}$; bu. $\$ 1.50$.

VIRGINIA WHITE DENT.

An old favorite Virginia sort, with a small cob and long, deep grains, making very large yields of fine marketable corn. Also makes fine ensilage corn. Pkt. 10c., postpaid; cit. 15c.; peck, 50c.; bu. \$1.40. In two bushel lots and over, $\$ 1.25$ per bushel.

\section{VIRGINIA FNSIIAGE CORN.}

This makes a larger growth and more fodder than any other sort, and we have sold it largely for a number of years, not only to farmers in our own section, but also in the North and West, and it has distinctly proven its superiority for ensilage and fedder purposes over other sorts. For Northern planting, climatic change makes Southern corn especially valuable for fodder and ensilage purposes. Pkt. 10c.; qt. $15 \mathrm{c}$; peck, $40 \mathrm{c}$; bu. $\$ 1.20$. Special price on large lots.

\section{Yellow Varieties of Seed Corn.}

\section{IMPROVID GOLDIN DENT.}

We have sold this splendid yellow corn for a number of years past, and believe it to be the best early or quick-growing yellow field corn in cultivation. It makes a large-sized ear, small cob, and deep grains, which are of a bright, attractive, golden-yellow color. This corn seems to be singularly robust, and withstands injury by wet weather, or other unfavorable conditions, better than any other sort we know of, the ears and grain maturing remarkably well, and always being marketed in a bright. sound condition. For a first-class. quick-growing, large-yielding yellow corn, this variety is, in our opinion, unsurpassed. Pkt. 10c.; qt. $15 \mathrm{c}$; ; peck, 50c.; bu. $\$ 1.40$; in 5-bu. lots and over, $\$ 1.25$.

\section{GOLDEN BEAUTY.}

Makes a large ear and large grained yellow corn later to mature than Improved Golden Dent. Very popular in Maryland, where it is very highly esteemed as a large yielding and most satisfactory cropping variety. Pkt. 10c.; qt. 15 c.; peck, 50c.; bu. $\$ 1.40$.

NEW WHITE CAP YELLOW DENT.

This corn has been grown in this section for a number of years, and, from reports from our customers, we believe it to be one of the best corns for poor or medium soils. It is early in maturity, making its crop in from 90 to 100 days, and makes a good-sized ear. It is not one of the largest fodder-growing rarieties, but for yield of corn we believe will surpass any other liind on poor or medium soils. The grain is of a light yellow color, and is a most excellent feeding variety. Pkt. 10c., postpaid; qt. 15c.; peck, 50c.; bu. $\$ 1.50$

\section{CLARK'S MASTODON}

This large-eared corn has been grown very largely in Virginia and other Southern States the past two years with the most satisfactory results, proving itself one of the largest yielding and most profitable field corns in cultivation. It is a dent variety, of strong growth, long grain, small cob, quick to ear and ripen, and one of the most productive of vellow corns. The seed of this variety does not generally please the eye, but the crop always pleases. Pkt. 10c., postpaid; qt. 15c;; peck, 50c.; bu. $\$ 1.50$

VIRGINIA YIIIOW DENT.

A standard variety of yellow corn; quick maturing and large yielding. Pkt. 10c.; quart, 15c.; peck. 50 c.; bu. $\$ 1.25$.

MMPROVED IEAMING.

A standard quick-growing yellow variety, highly esteemed by those who have grown it. It usually produces two ears to the stalk; is productive. 'Pkt. 10c., postpaid; qt. 15c.; peck, 50c.; bu. $\$ 1.40$.

\section{THE SOUTHERN PLANTER,}

\section{THE OLDEST AND BEST AGRICULTURAL PAPER PUBLISHED IN THE SOUTH.}

Gives the latest and most practical up-to-date information aiout larming, gardening, trucking, stock and poultry raising. Its subscribers pronounce it indispensable, and endorse it unhesitatingly as the most helpful and valuable agricuscural publication issued in this country.

Published monthly; 50 pages each issue. Subscription price, only 50 cents per year.

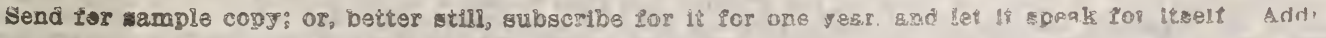

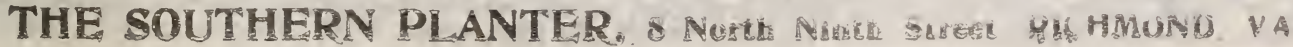




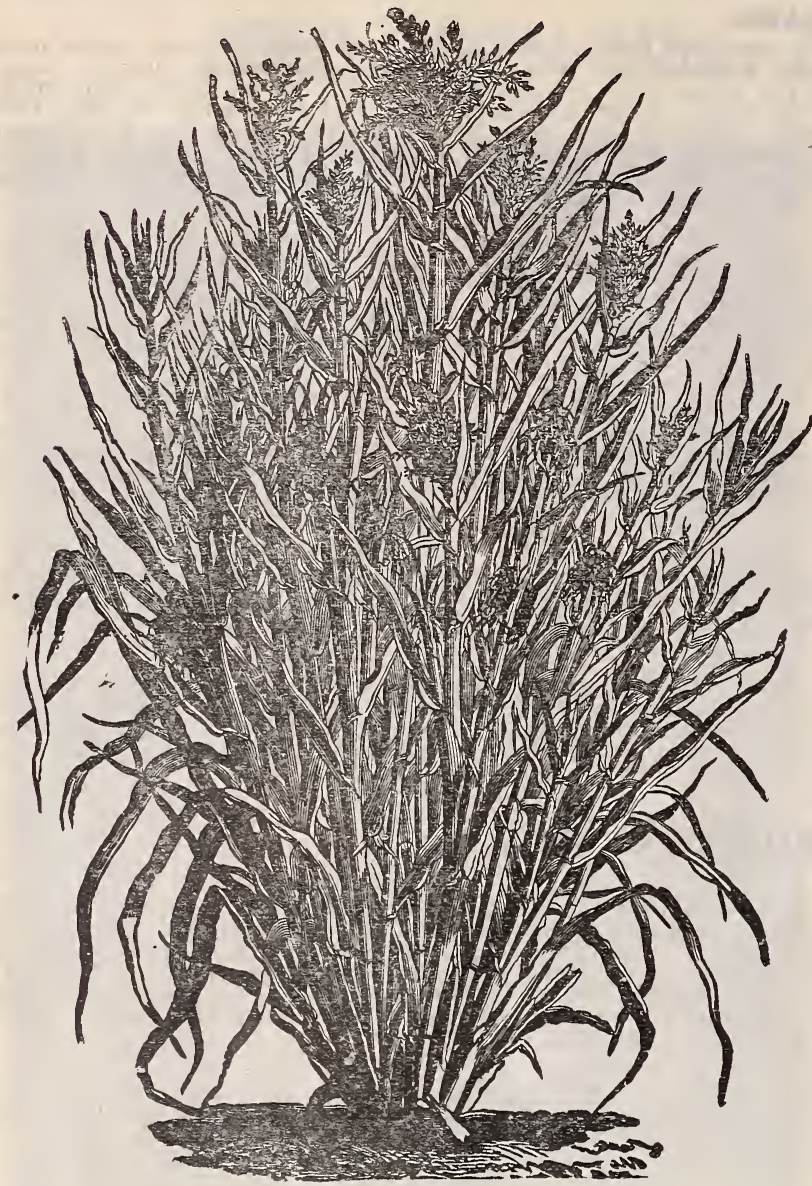

TEOSINTE.

\section{TEOSINTE.}

A Most Valuable and Enormous Yielding, Continuous Cutting Forage Crop.

We strongly recommend our customers who have not done so to sow this splendid forage crop. If a sufficient quantity is sown it will furnish a continuous daily supply of most nutritious green food for horses arid all kinds of cattle all through, horses arid all kinds of cattle all through'
the summer. It also makes splendid dry fodder, yielding enormously, and being more nutritious and even better relished by all kinds of stock than corn fodder. In appearance it somewhat resembles Indian corn, but the leaves are much larger and broader, and the stalks contain sweeter sap. In its perfection it produces a great number of shoots, growing ten to twelve feet high, very thickly covered with leaves, yielding an abundance of forage. It stools out enormously after being cut, as many as forty-five stalks having been grown from a single seed. The following extracts from letters from customers give some idea of its enormous yielding qualities:

"SOUTHAMPTON CO., VA., Oct. 24, 1901 - I consider Teosinte far superior to any crop I ever used as a long feed. Horses and cows are very fond of it. It is a splendid feed, either green or cured.

$$
\text { "H. T. GRIZZARD." }
$$

"CATATBA CO., N. C., Oct. 30, 1901The Teosinte grown from the seed purchased from you has given satisfactory results. I think it not too much to say that from eight to ten tons of green feed can easily be grown per acre. All kinds of stock relish it. All other seeds purchased from you have given good results.

$$
\text { "J. A. YOUNT." }
$$

"NEWBERRY CO., S. C.-I planted your Teosinte, and was very highly pleased. Cut over it seven times. I would not do without it. I also dried it like fodder. All kinds of stock love it. Neighbors heard of $\mathrm{my}$ patch and requested me to have your catalogue sent to them. "Mrs. T. J. MOFFETT."

Sow in May or June at the rate of two to three pounds per acre, in drills three and a-half to four feet apart. Oz. 10c.; $1 / 4$ 1b. 20c.; 1b. 60c. Special price in quan-
tity.

\title{
SORGHUM AND KAFFIR CORN--For Forage Crops.
}

\begin{abstract}
The sorghums will make a larger yield in the same length of time than any other forage crop, with possibly the exception of Teosinte. The use of sorghum as a forage crop has increased very rapidly in the past few years. There is no food that is more nutritious, or more greatly relished by cattle, and it should be one of the staple crops of every Southern farmer. It also makes an excellent green feed. It can be cut over two or three times during a season, yielding two or three crops from one seeding. For forage purposes, sow thickly at the rate of one to one and a-half bushels per acre, or for sorghum, sow in drills at the rate of one peck per acre. Sorghum will stand dry weather much better than millet, and is a much surer and larger yielaing crop, although not quite so easy to cure for dry feed.
\end{abstract}

\section{TARIY AMBER SORGEUM.}

Furnishes a large yield of most nutritious forage, which can be fed either green or cured, and will yield two or three cuttings a year, stooling out thicker each time it is cut. The saccharine matter is of the first quality, and it also produces a fine sugar or syrup. It grows ten to twelve feet high. Sow broadcast for forage at the rate of 1 to $11 / 2$ bushels per acre. When sown in drills, sow at the rate of one peck per acre in drills three and a-half to four feet apart. Pkt. 5c.; 1b. 10c.; peck, 60c.; bushel, about \$2.00.

\section{TARIY OIATGI SORGIU⿴囗.}

This variety is rapidiy growing in favor wherever it is grown. Similar in growth to the Early Amber, but it is claimed that it produces a heavier crop. Pkt. 5c.; 1b. 10.; ; peck, 60c.; bushel, \$2.00. Bushel price fluctuates.

\section{TAFrI COIJ.}

The great value of this crop has long been appreciated in the West, and it 1s to-day grown on the largest scale in the Western States. It makes a large growth of forage, and is also particularly valuable on account of its yield of grain, which makes most nutritious feed, both for feeding to all kinds of stock and to poultry. Kaffir Corn in the last few years has also been very generally sown with Cow Peas, broadand to poultry. Kafnr Corn in Corn helps to hold a peck of Kaffr corn to a bushel of cow Peas per acre. Srowth of Cow Peas, and both Corn helps to hold up the Cow Peas off the ground, and thus causes a larger grow th of Cow Peas, and both cown by itsele, Kaine com uhould be oown broedcast at the rate of from threo-quarters to one bushel

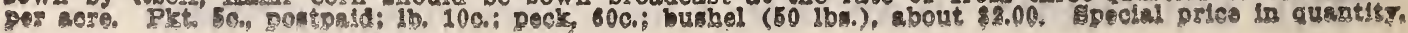




\section{PEARL OR CATTAIL MILLET.}

\section{Also Known and Sold as Pencillaria in the West.}

Makes a Splendid Forage Plant for either Green Feed or Fay. Can be Cut Several Times during the Season.

This makes a most nutritious and valuable continuous cutting forage plant, and is increasing in popularity all throughout the country. It will grow ten to twelve feet high, but cutting can be commenced when it has attained the height of three or four feet, when it will stool out enormously and make a rapid growth, and it can be cut this way three or four times in a season. It is largely used by dairymen and others who nave cattle for furnishing them green feed all through the summer, as, if a sufficient quantity is sown, it can be cut as desired, furnishing a daily supply of green food until killed by freezing tity is sown. it can be cut as desired, furnishing a daily supply of green food until killed by freezing ished by all kinds of stock. Sow five pounds of seed per acre in drills three feet apart, or sow broadcast at the rate of twenty to thirty pounds per acre. Pkt. $5 \mathrm{c} . ; 1 \mathrm{~b} .10 \mathrm{c} . ; 10 \mathrm{lbs}$. and over, 8c. 1b.; 100 lbs. and over, ic. $1 \mathrm{~b}$

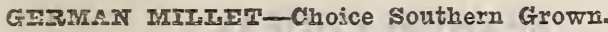

Southern Grown Nillet seed is far superior, both in quality and yield of product, to Western or Northern grown seed. The true German Millet, when properly grown and handled, makes an enormous yield of most nutritious feed and that without impoverishing the soil to any great extent. To get these results, however, German Millet must be sown thickly, about olle bushel per acre, and the crop cut while it is in however, German Millet must be sown thickly, about olle bushel per acre, and the crop cut while it is in
bloom. before the seed hardens in the head. Sow when the weather gets warm in May, or any time during summer until the end of July. Two crops can be seeded and grown during the summer on the same land. Price, about $\$ 1.25$ per bushel.

IUUNGARIAN. (Panicum Germanicum.)

For good low ground, on rich soil, this makes even a more valuable crop than German Millet. It is considered equal in nutritious qualities to Timothy hay. It is very important in procuring Hungarian Millet, to get the true seed, as common Millet resembles it very closely, and is frequently found mixed with Hungarian. This lessens both the yield and value of the crop Hungarian yillet should be sown from the first of May to the end of July, at the rate of one bushel per acre. Price, about $\$ 1.25$ per bushel.

\section{BUCKWHEAT.}

For a late summer crop, Buckwheat is very desirable and profitable, especially in mountainous sections, where Cow did flower food for bees and a large yield of grain; which can usually be sold for remunerative prices. It is also valuable for turning under as an improver of the soil. Even when grown for the grain crop, buckwheat is not considered exhaustive to the soil. As a smothering crop, where the land is full of objectionable weeds, it is very desirable, and it puts the soil in admirable condition for any crop that is desired to succeed it. Sow at the rate of one bushel per acre broadcast in June, July, or early in August.

\section{JAPAITESE.}

This variety of buckwheat ripens a week earlier than the Silver Hull, and yields more largely than that variety. The kernels are larger than those of other sorts, but owing to its branching qualities, it need not be sown quite so thickly. Per peck, 50c.; per bushel, about $\$ 1.20$.

\section{SIIVER 프I.}

A prolific and farorite sort, making a fine quality flour. A superior variety in every way to the ordinary buckwheat which it has almost entirely superseded. About $\$ 1.20$ per bushel. Current prices quoted on application.

\section{BROOMCORN, IMPROVED EVERGREEN.}

An excellent variety; it is a good length, fine, straight, and has a green appearance when ripe, and sells at the highest market price. Sow in drills three feet apart, and thin out to three inches. Sow 5 lbs. per acre. Pkt. 5c.; 1b. 10c.; bu. to three inches. Sow "Bs. per acre. Pkt. 5c.; "1 . 10.;.; bu. about growing and marketing broomcorn, $50 \mathrm{c}$, postpaid.

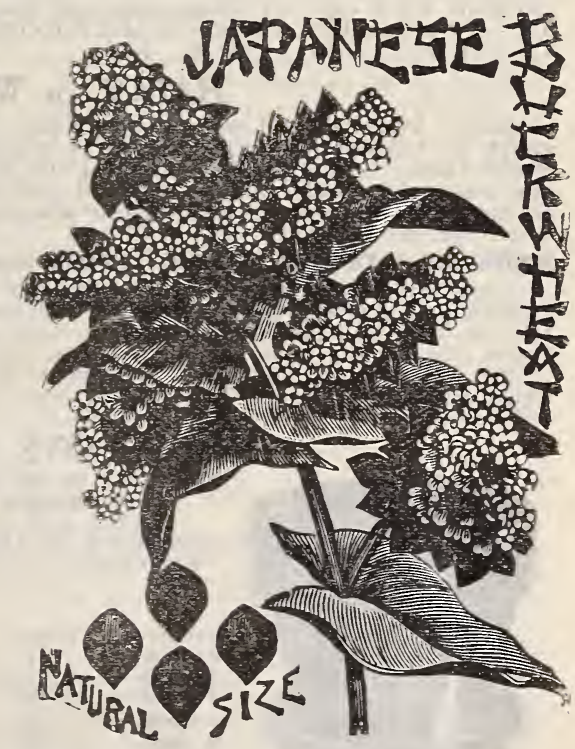

\section{CANADA FIELD PEAS.}

Canada Field Peas are entirely different from the Cow Peas, requiring to be sown during the winter and early spring, and making their crop ready for cutting in May or June. They are increasing in popularity, usually making a most satisfactory and large yielding early forage crop. They can be sown in open weather during December, January, February or March, at the rate of one and a-half bushels per acre by themselves, or, sown with oats, one bushel of the Peas and three-quarters of a bushel of Winter or Rust-Proof Oats per acre. Sowing with oats is of decided advantage, as the oats help to hold up the peas off the ground, enabling them to make better growth, and as they both mature together, they make splendid food, which cures admirably as hay or dried forage, which is greatly relished and is most nutrisplendid food, which cures admirably as hay or dried forage, which is greatly relished and is most nutri-
tious for all farm animals. This crop also makes a good soll improver when turned under like Cow Peas tious for all farm animals. This crop also makes a good soil improver when turned under like Cow Peas
or Crimson Clover. The price fluctuates. Price, about $\$ 1.75$ per bushel; cotton sacks holding two bushels each, $15 \mathrm{c}$. extra.

\section{DWARF ESSEX RAPE.}

A very quick-growing varlety of Rape, which makes excellent grazing for sheep; wkewise the leaves make very good salad cooked for tho table. It can be sown at any season of the year, but is not quite so satisfactory to use in midsummer as the cooler month of the year. It can be sown broadcast at the rate of elght pounds per acre and raked in or in drills fifteen inches apart, when four or five pounds will

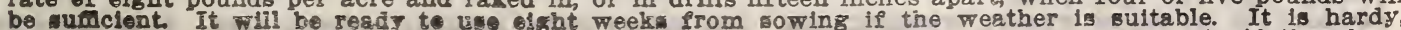

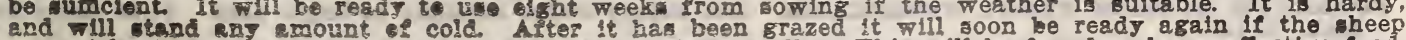

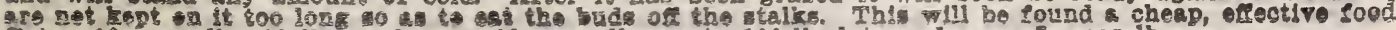

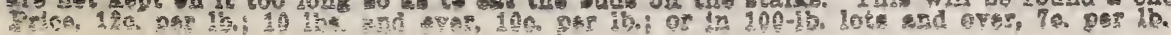




\section{JERUSALEM OR WHITE FRENCH ARTICHOKES.}

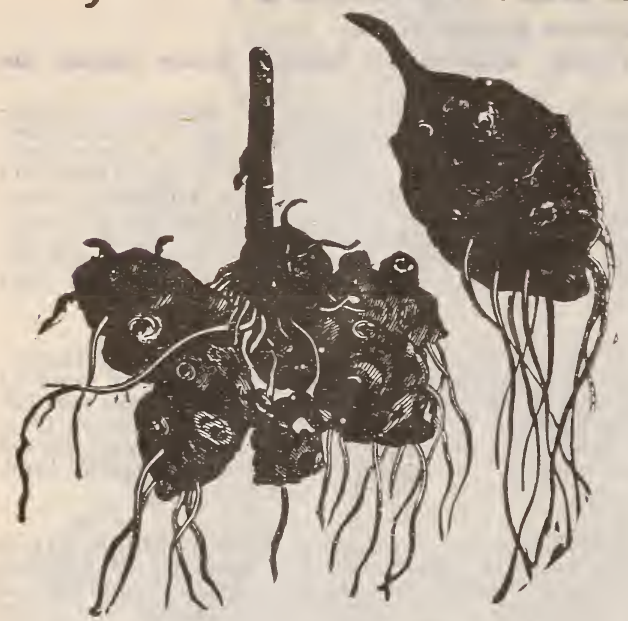

Jerusalem, or White French Artichokes.

These make an enormous crop of most healthy and nutritious feed for hogs, and all kinds of cattle; they will yield, ordinarily, twice as much as potatoes on the same land. Hogs can be turned on them about two weeks after the blossoms fall, and allowed to feed on the roots throughout the winter, except when the ground is frozen, until the plant begins to grow again. This saves the labor and expense of harvesting and storing, and will be found very economical. They are excellent for feeding to cattle and sheep, and prove a very profitable food.

Plant in February, March or April, in rows four feet apart, dropping the tubers fifteen inches apart in the rows. It requires from five to six bushels to plant an acre. Per qt. 15c.; peck, 50c.; bu. \$1.25. Special price in quantity.

\section{SPANISH CHUFAS.}

A nut grass largely grown in some sections for feeding to hogs, for which purpose they are highly recommended After the crop is grown hogs may be turned into the field, thus saving the labor of harvesting and feeding required by most crops for this purpose.

Culture.-They do best on light, sandy soil, or rather soil that does not contain too much clay except as a subsoil. They should be planted in drills two and a-half to three feet apart. dropping from three to five chufas in a hill fifteen to twenty inches apart. Cover to a depth of about two inches. They should be kept clean and the soil stirred occasionally. If for any reason an imperfect stand is obtained, the plants may be drawn and transplanted the same as sweet potato plants, and they will do just as well as if grown from the seed. Level culture is best. Chufas make rapid growth after coming up. When it is aesired to turn the hogs into them, it is best to pull up a few of the hills by the roots, and leave them on top of the soil, when, if either hogs or chickens get a taste of them, they will soon scratch over the whole field in their search for them. They are very productive, nutritious and fattening. They can be planted in May, June or early in July. Pkt. 10 c.; qt. 20 c.; peck, $\$ 1.00$; bu. $\$ 3.5 v$.

\section{HAIRY, or WINTER VETCH. (Vicia Villosa.)}

Hairy Vetch should be sown from July to October, either broadcast or in drills twelve to fifteen inches apart, at the rate of thirty to forty pounds to the acre, with three-quarters bushel of Winter or RustProof Oats. The oats help to hold the Sandvetch off the ground, enabling it to make a better growth, and making it more easily to harvest and cure same properly. In the North, where Winter and Rust-Proof do not stand the winter well, rye or wheat should be sown with Hairy Vetch. 12c. 1b.; 100-lb. lots and over, 10c. per $1 \mathrm{~b}$.

MITGISH WINTER VITCH. (Vicia Sativian)

Very similar in growth to the Hairy Vetch ("Vicia Villosa"), and makes a most nutritious forage crop, furnishing excellent winter grazing and green food in the early spring. Also makes a large yield of nutritious hay, and is an excellent soi improver. The Hairy Vetch seed being high in price this year, will cause this variety to be largely used in its place. It resembles it in all respects, and is a most satisfactory crop. In ordering please state whether you want the Fairy Winter Vetch or the English Winter Vetch. Price, 8c. per $1 \mathrm{~b}$. In $100-1 \mathrm{~b}$. lots and over, $61 / 2 \mathrm{c}$. per $1 \mathrm{~b}$.

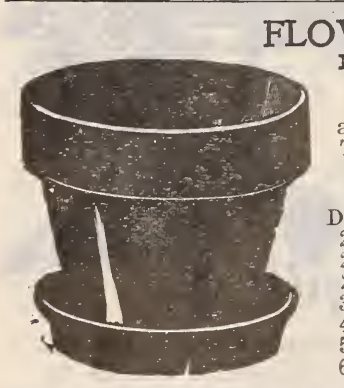

SAUCERS

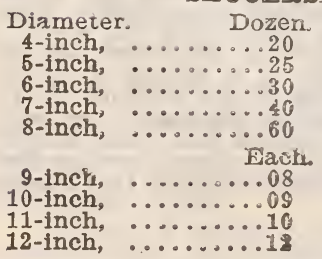

WER POTS AND SAUCERS - Very best quality.

Made for us by the best pottery in this country, and far better than the common pots usually offered. Special prices to florists using large quantities.

Charge will be made for packing pots, pans, and saucers at $25 \mathrm{c}$. for order amounting to $\$ 2.50$ or less. Larger orders proportionate charges will be made. This barely covers cost of packing.

\begin{tabular}{|c|c|c|c|c|c|c|c|}
\hline & & HAND & . & asiae is & D & & \\
\hline $\begin{array}{l}\text { Diameter. } \\
2 \text {-inch, } \\
21 / 1 \text {-inch, } \\
211 / 2 \text {-inch, } \\
3 \text {-inch, } \\
4 \text {-inch, } \\
\text { 5-inch, } \\
6 \text {-inch }\end{array}$ & $\begin{array}{l}\text { Dozen. } \\
\ldots 10 \\
\ldots 12 \\
\ldots 15 \\
\ldots 18 \\
\ldots .25 \\
\ldots .40\end{array}$ & $\begin{array}{r}\text { Per } 100 . \\
\$ .60 \\
.65 \\
.75 \\
1.00 \\
1.50 \\
2.75 \\
3.75\end{array}$ & $\begin{array}{r}\text { Per } 1,000 \\
\$ 4.50 \\
5.50 \\
6.50 \\
8.00 \\
12.00 \\
25.00\end{array}$ & $\begin{array}{r}\text { Diameter, } \\
7 \text {-inch, } \\
8 \text {-inch, } \\
9 \text {-inch, } \\
10 \text {-inch, } \\
11 \text {-inch, } \\
12 \text {-inch, }\end{array}$ & 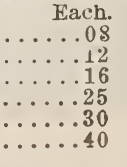 & $\begin{array}{r}\text { Per doz. } \\
\$ .85 \\
1.25 \\
1.75 \\
2.50 \\
3.00 \\
3.75\end{array}$ & $\begin{array}{r}\text { Per } 100 \\
\$ 5.75 \\
9.00 \\
15.00 \\
18.00 \\
25.00 \\
30.00\end{array}$ \\
\hline
\end{tabular}

SEATrOW POTS.

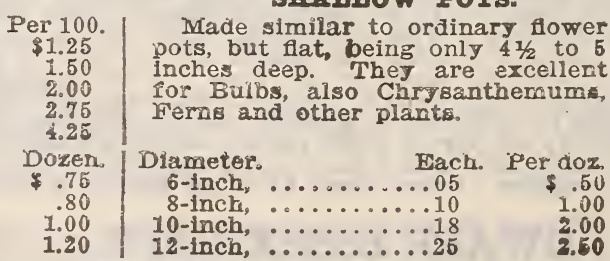

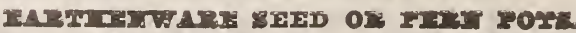

Round, flat, neatly maade pots, 3 to 4 inches deep. Splondid for Form or startins moed earl in the

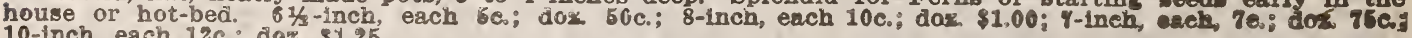
10 -inch, each 12c.; doz. $\$ 1.25$.

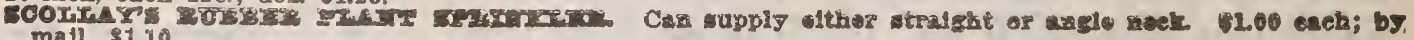
mall, $\$ 1.10$

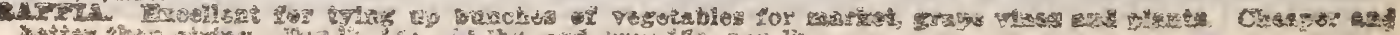

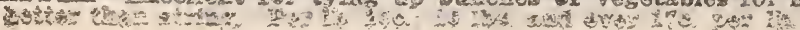


NEW AND IMPROVED VARIETIES OF COTTON SEED.

\section{RUSSELL'S BIG BOLL PROLIFIC CO'T'TON.}

Sinen its introduction, this cotton lias been very generally grown throughout the cotton States, and has unquestionably proved itself to be one of the most prolific and profitable varieties in cultivation. It has five locks in every boll. firmly set, thus largely inceasing the yield, and making it storm-proof. At, the same time it is easy to 125 bolls to weigh as it the This cuttur also takes deeper root than any variety ever produced, and on account of its viga pound. This cottom also takes deeper root than any variety ever produced, and on account of its vigorous wrowth. can witlistand droughts that would completely cut of other cottons. Farmer's who have
tried this cotton say that it puts on the earliest crop, and also the latest crop. of any variety known. It can be marketed before any other cotton, and many farmers have told us that this cotton keeps on maturing its crojs of green bolls after the common cotton has been killed by frost, and produced a fine crop when the old varieties make nothing. It produces a remarkably fine quality of lint, and the length of its staple. combined with its strength and fineness of fibre, enable farmers to sell this cotton at an advance of one-eighth to one-fourth of a cent per pound more than common cotton. This variety has also never been atticked by the insect commonly known as "sharp-shooters." on account of the extreme thickness of its burr, and it is not subject to blight and rust, and the sun-blisters. so frequently found on the bolls of common sorts, are never known to appear on the bolls of Russell's Big Boll Prolific. Price, per plist. 10c. special circular, giving full information and strong testimonials from farmers who have grown this variety, will be mailed free on application. Write for it if interested.

\section{MOORE'S EXCELSIOR PROLIFIC COTTON.}

The following is the description as given us by the originator of this variety: "The Excelsior Prolific stands first as being the most prolific cotton grown. Large bolls, small seed, with superior lint and staple. withstand drought better than any other variety. Will yield 40 per cent. of lint and from three to four bales of cotton per acre when well cultivated and scientifically fertilized. From hundreds of testimonials from the most prominent farmers in South Carolina, and from the very high endorsement of the Clemson College (South Carolina) Experiment Station, the Excelsior cotton stands second to none in practical field tests and experiments, and come as near being a thoroughbred for perfect cotton as it is possible to and easily picked. Price, per pkt. 10c., postpaid; lb, $20 \mathrm{c}$; peck, 50c.; bu $\$ 1.50 ; 5$ bu, and over, $\$ 1.25$ per bu.

\section{HAWKINS' EXTRA PROLIFIC COT'TON.}

This variety was originated by one of the most successful Georgia cotton-growers, and has become one of the most popular varieties grown all through the South. It is one of the earliest varieties, most prolific, and produces a most superior quality of lint and finest staple. A tall grower, long tap-root, enabling it to resist the drought; branehes out from two to foul limbs near the surface. Two short limbs together all the way up to the top, all literally covered with bolls. Produces soine large bolls and small seed of a light green or dark gray color, yielding from 38 to 40 per: cent. of lint. Opens well, growing much taller than other varieties, giving every advantage over other varieties in yield per acre. With judicious manuring, quick and rapid culture up to fruiting time, good land will grow three bales per acre planted in Hawkins' Prolific Cotton. This cotton received the first prize at the Georgia State Fair, at Macon, Ga. The Hawkins cotton, since it has been in use, has come to be the most popular variety grown in Georgia. The stalk is large, and the boll long and full, the fibre of the cotton, almost equal in length to the Sea Island Cotton, while the color of it is always perfectly white. TVe have large numbers of testimonials from the best cotton-growers throughout the South in regard to this variety. Pkt. 10c., postpaid; 1b. $15 \mathrm{c}$; peck, 40 c.; bu. $\$ 1.25$; in 5 -bu. lots and orer, $\$ 1.10$ per bushel

PETERIN'S IMPROVID COTTON. A valuable variety, largely grown in South Carolina and Georgia, and in great favor. It is a prolific, well-limbed, open growing variety, characterized by its small seed, and yielding nearly 40 per cent. of lint. The gross yield per acre compares with other leading varieties, while the net yield of lint per acre exceeds other sorts. The staple is equal to best grades of uplands, full length. strong and even. Bears drought better than the common cotton, and is not easily blown out by wind. Per pht. 10c., postpaid; lb. $15 \mathrm{c}$; ; peck. $40 \mathrm{c}$.; bu. $\$ 1.00$.

ALIEN'S IONG STAPLE. One of the best and most productive of the long staple varieties. Pkt. 10c.; lb. $15 \mathrm{c}$.; peck, 40c.; bu. $\$ 1.20$

SEA ISIAND. This variety is grown almost exclusively by the planters on the islands in the neighborloos of Charleston, S. C., whence it takes its name It produces the finest quality of lint of any American sort in cultivation. selling at a higher price than any other sort. We have made arrangements with one of the largest planters in the Sea Island district to supply us with an extra fine stock of this seed. Per pkt. 10c., postpaid; 1b. $20 \mathrm{c}$; ; peck, 40c.; bu. \$1.25.

\section{EGGS FOR SETTING-From Thoroughbred Poultry.}

On our farms and in our poultry yards we have the following thoroughbred poultry, all first-class stock, originally started from the best stocks in this country, and carefully cross-mated so as to give strong and vigorous stock and the best laying strains of the different breeds that it is possible to obtain. BARRED PIYMOUTH ROCK. America's popular favorites. Splendid general purpose fowls; recom mended strongly for prolific laying qualities and for market or table fowls. Our stock is unsurpassed. $\$ 1.00$ per setting.

BIACK IANGSHAN. The beautiful glossy black plumage of this breed always attracts attention. They are fine winter layers; fowls and chickens of large size and of very superior table qualities. Price, $\$ 1.50$

per setting.

BROWN IEGHORNS (Single Comb). Strong recommendation of this breed is its non-sitting and prolific laying qualities. Price, $\$ 1.00$ per setting

WHITE IEGHORN. Similar to the Brown Leghorn, except that the plumage is pure white. Price, $\$ 1.50$ per setting.

BUF PIYMOUTH ROCK. A superior strain of the Barred Plymouth Rock. Equally as prolific layers, and considered more desirable for market fowls, as they do not show dark pin feathers when dressed. $\$ 1.50$ per setting.

IIGET BRABMAS. Splendid winter layers. A fine market fowl laying eggs of the largest size, and making the quickest growing and best of spring chickens. It is really one of the mnst beautiful farmyard fowls, and attracts more favorable attention than any other breed. Our stock is very superior. Price, $\$ 1.50$ per setting.

WHITE WYANDOTTES. The Wyandottes are coming into great popularity. They are proving to be the best of general purpose fowls. Very prolific lavers; even more so than the Brown Leghorn or the famous Plymouth Rock. Also make fine spring chickens or broilers. Our stock is equal to the best in this country. Price, $\$ 1.50$ per setting.

BIACK MrNorCAs. Beautiful and ittractive fowls, and highly estecmed for their prolific laying and noll-sitting r111alities. price. $\$ 1.50$ per setting. Prices include packing and delivery at our stores or to express office here. 


\section{WOOD'S PURE ANIMAL BONE.}

\section{A First=Class Article of Finely Ground Bone, Specially Recommended for Fall Use on Grain,} Grass, and Clover Crops.

Pure animal bone is one of the best and most satisfactory fertilizers that the farmer can use. It can always be relied upon to give excellent results upon the growing crops, at the same time acting as a permanent improver, showing its results for several years afterwards wherever it is applied. It is the best of dry weather fertilizers, as, if it is prevented by drought from acting, its strength still remains in the soil, and is thus available when seasonable weather comes on, or for later crops.

It is ordinarily used at the rate of 300 to 500 pounds to the acre, although heavier applications are frequently made. It should be covered or incorporated with the soil at the same time as applied, in order to prevent the escape of ammonia. The guaranteed analysis of Wood's Pure Animal Bone is as follows:

Ammonia, 3 to 4 per cent.

Bone Phosphate.

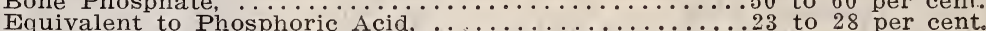

Price, $\$ 28.00$ per ton; $\$ 3.00$ per bag of 200 pounds. Special prices on large lots

\section{STANDARD FERTILIZERS.}

Our Standard Fertilizers are giving most excellent crop results to our customers, and we are constantly in receipt of most gratifying reports in regard to same.

The materials from which these fertilizers are made are of the best quality. The ammonia and nitrogen are derived from animal matter, such as meat, blood and fish, and high-grade sulphates and nitrates. The phosphoric acid is from high-grade acid phosphate and bone. The potash is derived from sources calculated to produce the best results on the particular crops for which they are recommended.

\section{STANDARD VEGETABLE FERTILIZER.}

Analysis.-Ammonia, 3 to 4 per cent.; Phosphoric Acid, 8 to 10 per cent.; Potash Soluble, 3 to 4 per cent. Bag (200 lbs.), \$2.50; per ton, $\$ 24.00$.

This fertilizer is specially prepared and highly recommended for all vegetable crops. It gives most excellent results on Peas, Beans, Cabbage, Melons, and Tomatoes. Use 300 to 400 lbs. per acre in hills or drills, or 600 to 800 lbs. per acre broadcast, mixing a little with the soil. A good substitute for stable manure, or can be used in connection with it.

\section{STANDARD POTATO FERTILIZER。}

Analysis:-Ammonia, 3 to 4 per cent.; Phosphoric Acid, 8 to 10 per cent.; Potash (actual), 5 to 6 per cent.; free from kainit, chlorides or muriates. Bag (200 lbs.), \$2.60; per ton, \$25.00.

This fertilizer is especially prepared for Irish and Sweet Potatoes, but will give splendid results on all root crops. On Irish Potatoes it will make large, smooth tubers of good keeping qualities. Use 800 to $1,000 \mathrm{lbs}$. broadcast, or $500 \mathrm{lbs}$. in drills. If used with stable manure, use $400 \mathrm{lbs}$. of fertilizer in the row. For Sweet Potatoes, 200 to $400 \mathrm{lbs}$ per acre will give good results for producing a large yield of smooth, good keeping roots. On Onions, Beets, Salsify, Parsnips, Carrots and Celery use 400 to 600 lbs. per acre in drills, mixing a little with the soil

\section{STANDARD CORN FERTILIZER.}

Analysis.-Ammonia, 1 to 2 per. cent.; Phosphoric Acid, 8 to 10 per cent.; Potash (actual), 1 to 2 per cent Bag (200 lbs.), \$1.70; per ton, $\$ 16.00$.

This is specially prepared for the corn crop, containing the necessary ingredients to insure successful crops. It will largely increase the yield of both grain and fodder, besides proving of permanent benefit to the land. Use 200 to $400 \mathrm{lbs}$. per acre in drills.

\section{STANDARD GRAIN AND GRASS FERTILIZER.}

Analysis.-Ammonia, 2 to 3 per cent.; Phosphoric Acid, 8 to 10 per cent.; Potash (actual), 2 to 3 per cent Bag (200 lbs.), \$2.10; per ton, $\$ 20.00$.

This brand is specially prepared for all grain and grass crops. It is quick-acting, and at the same time lasting in its results, largely increasing the grain crop, and at the same time acting as a permanent improver, thus also benefiting the grass or clover crop materially, or leaving the land in better conditio: for any, thus also bent may follow the core when drilled with the

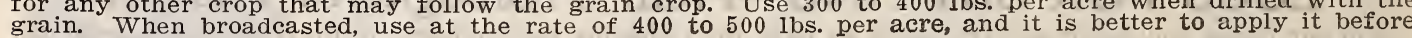
seeding the grain and to harrow all in together.

\section{LISTERS’ STANDARD BONE SUPERPHOSPHATE.}

LISTERS'
S T A ND A R D
is made
purely from an animal
bone and blood basis.
No acid phosphate or
Charleston rock is used
in same.

The excellent reputation of this brand in the twelve years we have been supplying it to our customers has been fully maintained, both in satisfactory crop results and in the permanent improvement of soils resulting from its sulting from its use. Being made purely from an an in which the phoscannot, of course, phoric acid is derived from acid phosphate; and while fertilizers deriving results, still it is the opinion of many practical farmers that the anima bone basis fertilizers are more reliable and lasting in their effects, and that they give much surer and better results in dry seasons.

ITSTFR' STANDARD is a complete manure, containing all the elements of plant food, and can be used on any crop as a substitute for stable manure, or, used with it, will give much better results than the use of manure alone. It gives the most satisfactory results on all farm and vegetable crops, being especially recommended for both Late and Early Cabage Potatoes, Peas, Melons, Cucumbers, Tomatoes and Corn. It is also excellently adapted for use on grain crops, especially those to It is also excellently adapted customers who have used it for years probe followed by grass. Our customers who have used it for years pronounce it to be one of the most reliable fertilizers for all seasons, whether
wet or dry, that they have ever used. Analysis.-Ammonia, 3 to 4 per cent.; Phosphoric Acid, 9 to 10 per cent.; Solu 


\section{MAPES ${ }^{\dagger}$ MANURES.}

\section{MAPES' MANURES}

are made from boneand

high grade materials; no acid phospliate used. For splendid crop results, high qual= ity, and large yields, they are unequalled.
The Mapes Company is one of the oldest and most reliable fertilizer concerns in the country: It is thoroughly independent of any of the trusts or combinations which have been entered into for the manufacture of fertilizers, and puts up a fertilizer which is entirely different from the fertilizers manufactured by those combinations, in that the Mapes Company does not use acid phosphate as a basis for its fertilizers, but makes them purely from animal bone and other high-grade materials. The Mapes Manures, too, are the results of years of experience and careful experiments, by thoroughly competent men, with the different crops for which they are recommended. Our most successful customers have used these high-grade manures in the largest quantities rear after year, and recommend them in the strongest terms for high quality, profitable erops and permanent improvement of the soil. Special circular and descriptive pamphlet giving full information about Mapes' Manures, mailed free upon request.

\section{Mapes' Vegetable Manure, or Complete Manure for Light Soils.}

\section{SUPERIOR TO PERUVIAN GUANO FOR QUICX RISUITS AND IASTING BENFFIT\&.}

Analysis.-Ammonia, 6 to 8 per cent.; Phosphoric Acid, available, 6 to 8 per cent.; Soluble Potash, 6 to \& per cent., all as high grades Sulphate and in forms free from muriates (or chlorides).

Bag (200 lbs.), \$4.25; per ton, \$42.00.

A strictly high grade fertilizer, especially adapted for use by truck-growers, and on all classes of soil, with or without stable manure, for vegetables, insuring quick growth, tenderness, productiveness, fine flavor, nutritious quality, and early maturity-one to two weeks earlier than by usual methods. It is specially recommended for and is largely used by our leading truckers upon the following crops: Radishes, Lettuce, Beets, Onions, Peas, Snap Beans, Tomatoes, Cucumbers, Pepper, Spinach, Early and Late Cabbage, Egr Plant, Early Turnips, Melons, Squashes, and Asparagus beds.

This fertilizer is also, from the nature of its analysis and constituents, a complete manure for light soils, and on this class of soils will give the most excellent results on all farm crops, including Corn, Grass and Grain crops. On heavier soils for these latter crops we would, however, recommend the Complete Manure.

\section{Mapes' Complete Manure, "A" Brand.}

Analysis.-Ammonia, 3 to 4 per cent.; Phosphoric Acid, soluable and available, 10 to 12 per cent.; Soluble Potash (actual), $2 \frac{1 / 2}{2}$ to $3 \frac{1}{2}$ per cent. Bag (200 lbs.), $\$ 3.65$; per ton, $\$ 36.00$.

\section{AN FXCFIIENT SUBSTITUTE FOR STABIE MANURE.}

This is a complete manure for all crops, specially prepared for use on average good or heavy soils. On this class of soils it is specially recommended for use on general farm crops, such as Corn, Millet, Oats, Wheat, Rye, and for all grain ciops and seeding to grass with or without grain. The drilling quality of this manure and its effect on Wheat, Rye, and succesding grass crops, have achieved for it, after many years' use, a very high reputation.

\section{Mapes' Economical Potato Mlanure. Bag (200 lbs.), \$3.65; per ton, \$36.00. SUPERIOR TO STABIE MANURE FOR THIS CROP.}

Analysis.-Ammonia, 4 to 5 per cent.; Phosphoric Acid, 6 to 8 per cent. (soluble and available, 4 to 5 per cent.); Soluble Potash (actual), 8 to 10 per cent.

(Potash is in the form of high-grade Sulphate and free from Muriates and Chlorides.)

This is far superior to stable manure for this crop. Produces better and smoother potatoes, and makes a much larger yield. It is specially prepared and recommended for both Irish and sweet Potatoes and also gives excellent results on Asparagus, Beets and other root crops, and is also well adapted and gives the most satisfactory results on Strawberries, Raspberries, and all small fruits. Use 300 to 400 los per acre in drill for Irish Potatoes, or 500 to 1,000 lbs. broadcast; for Sweet Potatoes, 200 to 300 lbs. per acre in drill.

\section{Mlapes' Tobacco Manure. Bag (200 lbs.), \$3.75; per ton, $\$ 37.00$. \\ PREPARED SPECIAIIY FOR PRODUCING THE FINEST OUALITY IFAF.}

Analysis.-Ammonia, 5 to 6 per cent.; Phosphoric Acid, 4 to 6 per cent.; Soluble Potash, 6 to 7 per cent.

Ammonia derived from No. 1 Peruvian Guano and other sources. Potash from high-grade Sulphate, and entirely free from Muriates and Chlorides.

This is a complete tobacco manure, specially prepared for producing a superior quality of leaf, both for fillers and wrappers. It is compounded with a view of meeting the conditions present in the soils of Virginia and North Carolina naturally selected for tobacco. The materials used are based on accurate knowledge from a long experience of practical tests. The results from the use of this Mapes' Tobacco Manure have been most satisfactory, and we strongly recommend our tobacco-growers who are desirous of raising large crops of the finest quality of tobacco to use this brand. The well-known reliability of the Mapes Company. together with the splendid reputation for crop results which their fertilizers hav made, warrant the use of this brand on the largest scale by tobacco-growers everywhere.

WOOD'S PURE ANIMAI BONE. Price per bag (200 lbs.), \$2.60; per ton, $\$ 25.00$ see page 74.

IAND PIASTER. See page 63 for full information. Price, $75 \mathrm{c}$. per bag; $\$ 7.00$ per ton.

MADISON CO., VA., Feb. 6, 1902.-I think your seeds better than any I have bought. I find the packages are fuller and nicer quality seeds. and the fruits a superior quality to any others I have tried.

\section{To grow the finest quality of \\ Leaf Tobacco use \\ MAPES' \\ TOBACCO MANURE.}




\section{POULTRY SUPPLIES.}

\section{พ}

Laying hens should have at least one feed a day of ground food. This is more easily digested, anu gives better results than whole grain. The formula of Wood's Practical Rations is the result of long experience and exhaustive tests, and is the very best that can be compounded. It has given the most satisfactory results, and it is largely used by the best and most experienced poultry raisers in this country. It is a complete food, containing all the elements (meat, bone, etc.) necessary for egg production. Wre use it largely ourselves in our own poultry yards, and can recommend it with confidence to our customers.

Wood's Practical Rations should be fed once a day (in the morning is hest), made into a mash, by mixing with water or skim milk. There can be no fixed rule as to the amount of food to give a flock: the quantity that hens will eat varies with whether conditions, etc.; and the quantity to be given can only be told from experience. They should. however, be fed all of wood's Practical Rations that they will eat up clean in about twenty minutes. Whole grain should be fed for the afternoon meal. A change of food is just as desirable for poultry as for people.

Price, per $100-1 \mathrm{~b}$. bag, $\$ 2.50$; per $50-1 \mathrm{~b}$. bag, $\$ 1.40$; trial package of $15 \mathrm{lbs}$., 50c. Special prices on larger

MIAT MIEAI. Animal food is very necessary for poultry in winter to keep them in good laying condition. This Meat Meal is a splendid meat food; should be mixed with wet food. 5 1bs. $20 \mathrm{c} . ; 251 \mathrm{bs}$. $75 \mathrm{c}$. 50 bs. $\$ 1.40 ; 100$ lbs. $\$ 2.50$. We can also supply a mixed Bone and Meat Meal at same price.

FINE BONE MIEAI. Excellent to aid in increasing egg production, and a splendid feed for young chicks. Should be fed wet, mixed with corn meal or bran. 5 lbs. $20 \mathrm{c}$; 25 lbs. $85 \mathrm{c}$; 100 lbs. $\$ 2.75$.

CRUSHED or GRANUIATED BONE supplies the lime for shell and other ingredients necessary in the composition of eggs. Scatter about the poultry yard. 5 lbs. 20 c.; 25 lbs. S5c.; 100 lbs. \$2.75.

CRUSHED OYSTFR SHEIIS. Splendid for poultry, to help in the formation of egg-shells and keep fowls healthy. Use it freely. Feed alone. $15 \mathrm{lbs}, 25 \mathrm{c}$; $40 \mathrm{lbs}$. 50c.; $100 \mathrm{lbs}$. $75 \mathrm{c}$.

MICA CRYSTAI GRIT. The sharpest and hardest grit known. It is absolutely necessary for fowls to have grit in order to keep them healthy and free from cholera, etc., and their kindred diseases. Grit is the chickens' teeth, and the absence of plenty of grit often means the difference between success and failure with poultry. Price, 5 lbs. 15c.; 25 lbs. 40c.; 50 lbs. 60c.; 100 lbs. $\$ 1.00$. Special prices by the ton.

RUST'S FGG PRODUCFR. One of the best and most satisfactory preparations we have ever sold for feeding to poultry to increase egg production. Our custemers who have used it speak in the highest praise of it, saying that it not only larga $y$ increases the quantity of eggs. but improves the appearance and condition of th pcultry. Feed every day at first at the rate of one tablesponnful to a quart of meal or wet feed; afterwards two or three times a week, and when the hens commence laying freely it can One pound package, $25 \mathrm{c}$; by mail, 44c.; $2 \frac{1 / 2}{2}$ pound package, 50c.; by mail, 94c.; 6-1b. package, $\$ 1.00 ; 10$-1b. package, $\$ 1.50$.

RUST'S HAVEN'S CLIMAX CONDITION POWDERS. A first-class preparation for poultry and cattle. A splendid cure for cholera and other poultry siseases; it tones up the system and greatly improves the plumage after the trying moulting season. It is also a good medicine for hogs, cattle, and horses, and gives splendid satisfaction to our customers who use it. $13-\mathrm{oz}$. box, 25c.; if by mail, $40 \mathrm{c}$; $32-\mathrm{oz}$. box, $50 \mathrm{c}$; if by mail, $85 \mathrm{c}$;
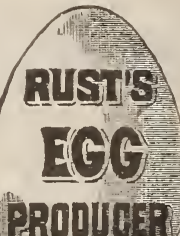
5 -1b. box, $\$ 1.00 ; 8-1 b$. box, $\$ 1.50$.

BOUP PIIIS. An almost sure cure for Roup, given according to directions. We have known almost hopeless cases cured by it. Per box of 50 pills, 25c. Mailed on receipt of price.

RUST'S IICE-KIIIING PAINT. Diluted with kerosene, this makes an efficient Liquid Lice-Killer, splendid for painting roosts, boxes, etc. Price, $4-\mathrm{oz}$. box, sufficient to make one quart, $10 \mathrm{c}$, or, postage paid, $15 \mathrm{c}$; $16-\mathrm{oz}$. box, sufficient to make one gallon, $25 \mathrm{c}$, or, postage paid, $40 \mathrm{c}$.

RUST'S IICE-KIIIING POWDER. For dusting fowls and nests. Price, 10c., or, postage paid. $15 \mathrm{c} . ; 16-$ oz. box. $25 \mathrm{c}$; p postage paid, $40 \mathrm{c}$. Circular giving information regarding Rust's Preparations mailed upon request.

IAMBERT'S DEATH TO IICE. A powdered preparation for dusting on setting hens and also on laying fowls and other large chickens. Price, $25 \mathrm{c}$. per package. If by mail, $42 \mathrm{c}$.

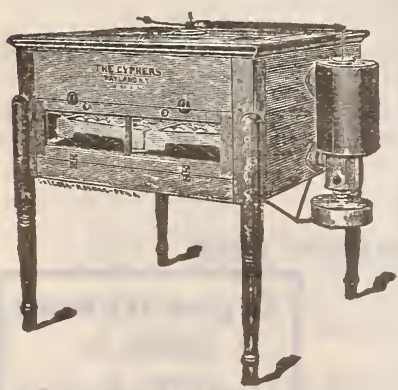

SANITARY DRINKING FOUNTS. Made of galvanized iron; a most satisfactory fount, both for large poultry yards and small chickens. Always keeps the water fresh and clean. Four-quart, 50c.; S-quart or 2 -gallon founts, $\$ 1.00$

SANTTARY FEED BOXES. Keep the feed fresh and sweet; three divis. ions; self-feeding. $50 \mathrm{c}$. each.

\section{CYPHERS' INCUBATORS.}

The Cyphers' Incubator is beyond all question the best and most satisfactory incubator offered to-day. The hatching of chickens by incubators is becoming a very important and profitable branch of the poultry business, and is being very generally and successfully followed now all over the country. It is much more satisfactory and more easily managed than the old-fashioned method of setting the hens.

It is most important, howerer, to have a first-class incubator in order to conduct the business with success and profit. There are a good many cheap incubators on the market which do not give satisfaction, the use of which has caused some people to become discouraged with what, under proper management and with a first-class incubator. proves to be a most satisfactory and profitable source of income. "Whatever is worth doing at all, is worth doing well," applies in the strongest possible way to the hatching of chickens by incubatored.

a Cypher' Incubator, and with a little
CYPHrRs' IrCUBATORs.

No. 0, Capacity, 60 eggs,

No. 1, Capacity, 120 eggs,

No. 2, Capacity, 220 eggs,
CYPHERS' BROODERS.

$\$ 14.00$

29.00

Style B, Indoor, 150 chicks.

Style B, Indoor, 150 chicks, $\$ 10.00$ 12.00

Prices of larger sizes quoted upon request.

With a Cyphers' Incubator and Cyphers' Bronder there is no trouble about hatching narly chicks and having same on the market at the times when chickens are most profitable. Properly handled. a Cyphers' Incubator and a Brooder will bring in a steady and satisfactory income all through the year. profitable poultry breeding in all its branches. will be mailed upon request.

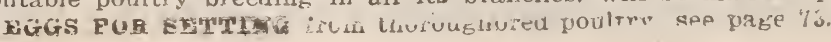




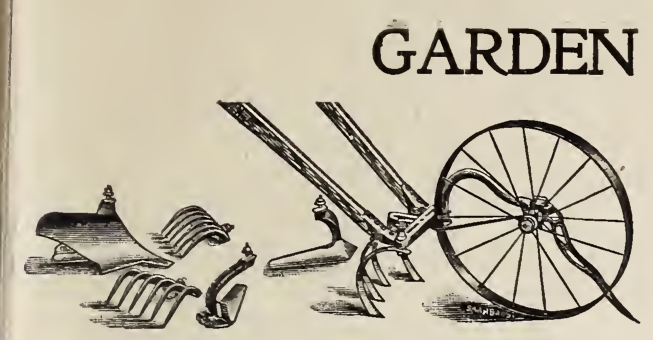

PLANET, JR., HAND TOOLS.

No. 1 Combined Drill, Cultivator, Rake and Plow

No. 2 Drill Seeder

No. 3 Hill Dropper a n

No. 4 Hill Dropper, Drill Seeder, Cultivator, Rake, and Plow, .............................. No. 12 Double Wheel Hoe, Cultivator and No. 16 single Wheel Hoe, Cultivator, Rake,

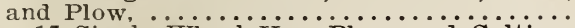

No. 17 Single Wheel Hoe, Plow, and Cultiva-

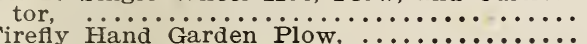

\section{NECESSITIES.}

The modern hand garden tool should be in every garden, however small. The time saved and the more thorough manner in which the work is done will many times repay the cost. They will do the entire work of the garden, from the breaking of the ground up to the last working. Write for complete catalogues of Planet, Jr., and Iron Age tools-they are mailed free on application.

\section{IRON AGE HAND TOOLS.}

No. 16 Hill Dropper and Drill Seeder, ......\$750 No. 6 Combined Hill Dropper, Drill Seeder. Double Wheel Hoe, Cultivator, Rake, and 1100

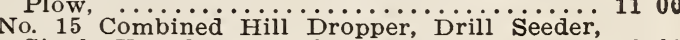
Single Wheel Hoe, Rake, and Plow, ....... 1000 No. 1 Double Wheel Hoe, Cultivator, Rake, and Plow, ..................... 650 No. 9 Single Wheel Hoe, Cultivator, Rake, and Plow, .................... 475 No. 12 Wheel Plow and cultivator, .............. 3 25 No. 11 Wheel Hand Plow, ................... $2_{2} \quad 25$

IANG'S HAND WEEDER. Should be in use in every garden; handy in weeding close to the plant. $25 \mathrm{c}$. each; by mail, $30 \mathrm{c}$.

COMBINATION PRUNER. A shear and draw knife pruner combined. Indispensable in the orchard and garden. $\$ 1.00$

CFISFI PRUNER. A time and labor-saver. A quick stroke makes a clean cut; operated from the ground. $\$ 1.00$.

FRUIT PICKER. Picks fruit without bruising, preventing injury to delicate or over-ripe fruit. \$1.00.

\section{SPRAYERS AND DUSTERS.}

When buying a sprayer, get the best. It costs more to begin with, but is cheaper in the end, lasting longer than cheap sprayers, and can be relied upon when wanted.

Write for Complete mlustrated sprayer Catalogue, mailed free.

COPPER KNAPSACK SPRAYRR. Made entirely of brass and copper; ball valves and metal plunger, all easily accessible. The tank is heavy copper, and holds five gallons. Price, $\$ 9.50$.

TRI-JET HAND SPRAYER. Useful in small gardens, greenhouses, poultry houses, and for house plants, applying liquid insecticides in a fine mist. Price, tin, 50c.; brass, $\$ 1.25$.

THE COMPRESSED AIR SPRAYER. Operates by compressed air. Will throw a fine spray or a solid stream, as desired. The tank holds four gallons. Price,. \$2.25.

FOUNTAIN KNAPSACK SPRAYIR. This machine meets every demand for a cheap sprayer, and will a ply any soluble insecticide. Holds five gallons. Price, \$3.00. Extra bulbs, 50c. each.

BARREL SPRAYrRS. Those having large areas or many trees to spray will find it pays to use large sprayers. We will be glad to quote barrel spray pumps on request.

IITIE GIANT DUSTER. Distributes Slug Shot, Paris Green, London Purple, Pyrethrum or any dry powdered insecticide effectively and economically. Price, $\$ 5.00$.

BEILOWS DUSTrR. An economical and effectual device for applying Paris Green and other dry powder insecticides. Intended originally for use in small gardens, but has proved quite a success in the field Price, $\$ 1.00$.

\section{INSECTICIDES AND FUNGICIDES.}

\section{WRITE FOR COMPIFTE DESCRIPTIVE CIRCULARS.}

HAMMOND'S SIUG SHOT. For cabbage and tobacco worms, potato bugs, etc. Positively non-poisonous and not dangerous to handle, like Paris Green. Pamphlet giving full information free on request. 5-lb. packages, 25c.; 100-lb. lots 41/4c. per lb.; barrels (235 lbs. in bulk), 4c. per lb. Small dusters for applying, $10 \mathrm{c}$; ; large canisters, $50 \mathrm{c}$.

TOBACCO DUST. A most effective remedy for lice and worms on cabbage, striped bugs and other insects on melons, cucumbers and squashes. Dust on young plants when the dew is on. 15 lbs. $25 \mathrm{c}$.; 40 lbs. 50 c. $; 100$ lbs. $\$ 1.00 ; 1,000$ lbs. $\$ 7.50$.

PARIS GREEN. A strong poison, and should be used with care. Mix $1 \mathrm{lb}$. of Paris Green to $501 \mathrm{~b}$. of plaster, or with water to 150 gallons. On vines and tender vegetables use a larger proportion of plaster or water. Per lb. $25 \mathrm{c}$. Special price on large lots.

BORDEAUX MIXTURE. In concentrated and convenient form. Ready for use simply by the addition of water. Works freely and uniformly without clogging, permitting of very fine spray and consequent economical distribution of a small quantity evenly over a large area. Per gallon, $\$ 1.00$.

WHAIE OIL SOAP. Tsed as a wash on trees, destroying all insects on the bark. Specially recommended for San Jose scale. Per lb. $15 \mathrm{c}$.; 5 lbs. for $60 \mathrm{c}$.

KRROSFNE FMULSION. A most effective insecticide for San Jose scale and other sucking insects, cattle and horn fly, for spraying poultry houses, etc. Kills by contact. Our emulsion is carefully made, and will not injure the foliage. Ready for use by adding water. 5-1b. can (makes 50 gallons), $75 \mathrm{c}$.

THYMO CREsOL. A perfect Sheep Dip. Invaluable for dog-kennels, poultry-houses, etc. Rapidly fatal to all insect pests which infest domestic animals, but positively harmless to the skin. Heals eruptions and cuts, and promotes new growth of fine hair and wool. A splendid disinfectant. Small bottles. $20 \mathrm{c}$; by mail, 30c.; large bottles, 35c.; by mail, 50c.; qt. 65c.; $1 / 2$ gal. $\$ 1.00 ; 1$ gal. $\$ 1.75$.

IFMON OII INSECTICIDE. The best remedv for green fly, red spider, scale, mealy bug, mildew, etc., on house plants. Destroys lice and inscets either as a wash or by spraying. Directions on each can. Half-pint, $25 \mathrm{c}$.; by mail, $35 \mathrm{c}$.; 1 pint, $40 \mathrm{c}$; by mail, $60 \mathrm{c}$; 1 qt. $75 \mathrm{c}$.; $1 / 2$ gal. $\$ 1.25$; 1 gal. $\$ 2.00$. 


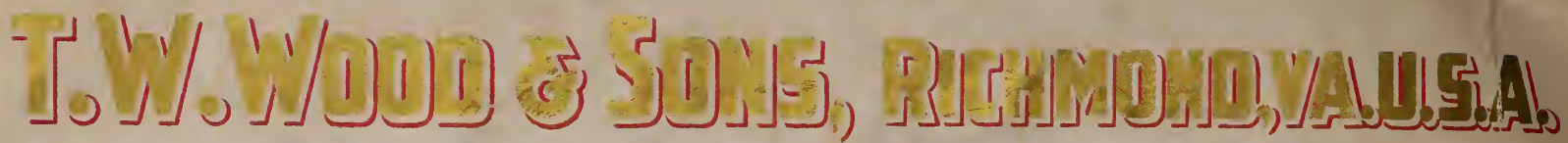
STORE \& OFFICE:

WAREHOUSES:

$8,10 \& 12$ SOUTH $14^{\text {TH }}$ ST.

1323 EAS.T MAIN ST.

BRANCH STORES:

6 TH \& MARSHALL STS.

1707 EAST FRANKLIN ST.

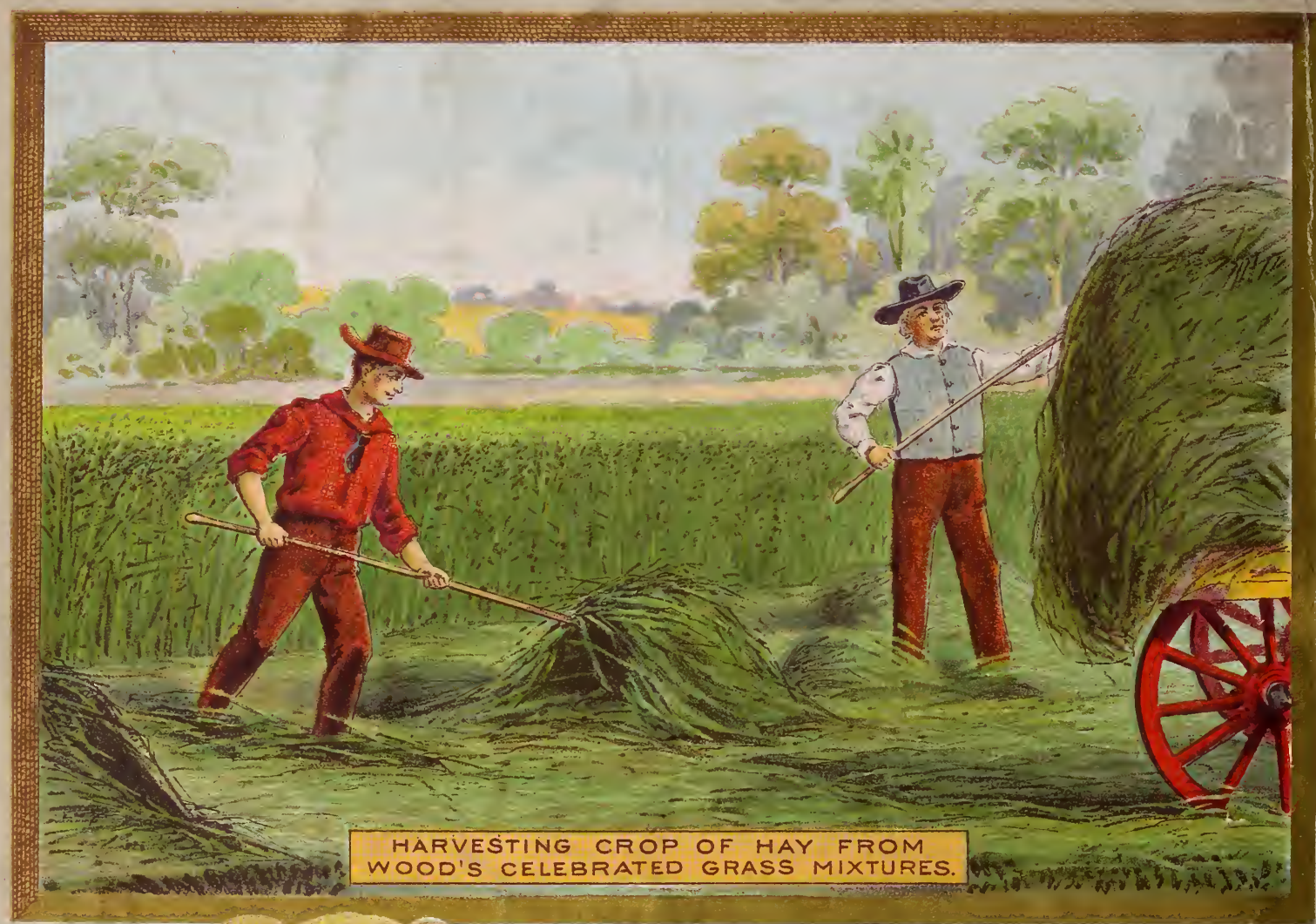

EYWHIFEROSE
POTATOES

POTATOES. क w , w
SEED FARMS.

OAKLAND, CHESTER \& HOLLYBROOK.

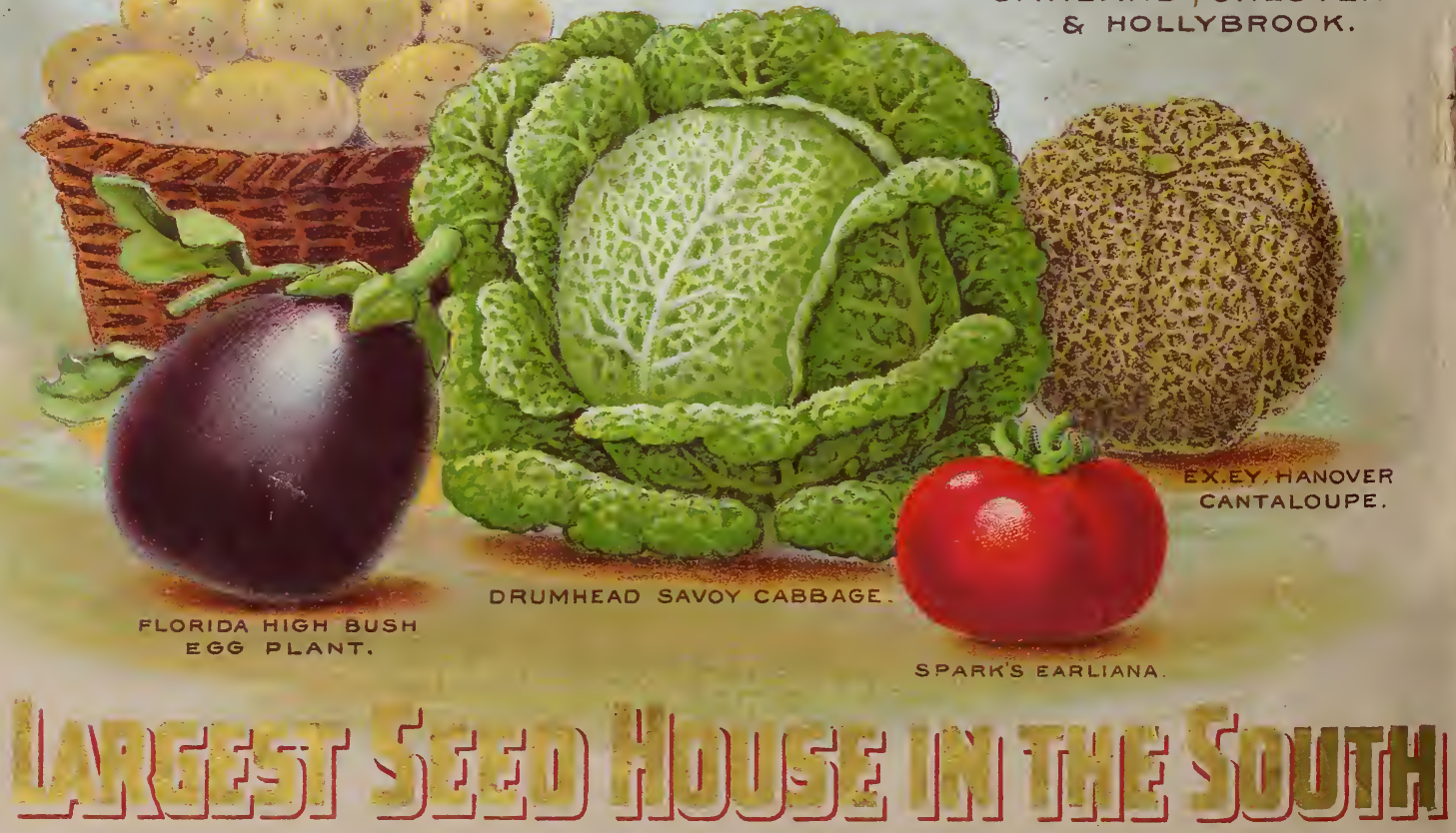

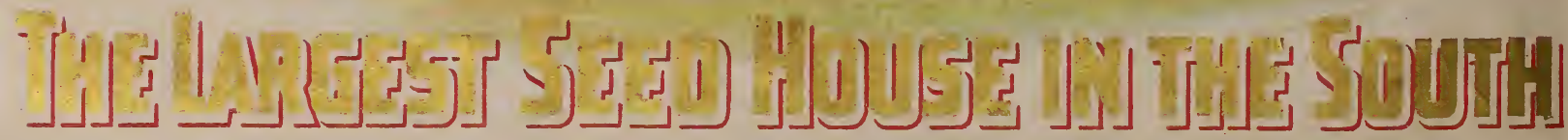

